\author{
UNIVERSIDADE DE SÃO PAULO \\ FACULDADE DE FILOSOFIA, LETRAS E CIÊNCIAS HUMANAS \\ DEPARTAMENTO DE GEOGRAFIA \\ PROGRAMA DE PÓS-GRADUAÇÃO EM GEOGRAFIA FÍSICA
}

ANDRÉ HENRIQUE BEZERRA DOS SANTOS

\title{
Condicionantes estruturais da drenagem e do relevo na cratera de Colônia e entorno, São Paulo - SP
}

Versão corrigida, conforme a Resolução CoPGr 6018, de 13 de outubro de 2011

São Paulo

2013 


\section{ANDRÉ HENRIQUE BEZERRA DOS SANTOS}

Condicionantes estruturais da drenagem e do relevo na cratera de Colônia e entorno, São Paulo - SP

Versão corrigida, conforme a Resolução CoPGr 6018, de 13 de outubro de 2011

Dissertação apresentada à Faculdade de

Filosofia, Letras e Ciências Humanas da Universidade de São Paulo para obtenção do título de Mestre em Ciências.

Área de Concentração: Geografia Física

Orientadora: Profa. Dra. Déborah de Oliveira

São Paulo

2013 
SANTOS, A. H. B. Condicionantes estruturais da drenagem e do relevo na cratera de Colônia e entorno, São Paulo-SP. Dissertação apresentada à Faculdade de Filosofia, Letras e Ciências Humanas para obtenção do título de Mestre em Ciências.

Aprovado em:

\section{Banca Examinadora}

Prof. Dr.: Instituição:

Julgamento:

Assinatura:

Prof. Dr.: Instituição:

Julgamento: Assinatura:

Prof. Dr.: Instituição: Julgamento: Assinatura: 


\section{Agradecimentos}

Ao Departamento de Geografia da Universidade de São Paulo, pelo uso de suas dependências e à CAPES, pela bolsa de estudos concedida.

À minha orientadora, Profa. Dra. Déborah de Oliveira, por tornar possível a realização desta pesquisa e por me proporcionar muita confiança e entusiasmo nos momentos mais difíceis desta tortuosa trajetória da vida acadêmica.

Ao Prof. Dr. Jurandyr Luciano Sanches Ross, por ter me motivado a seguir os rumos da ciência geomorfológica e por sua importante ajuda em minhas atividades acadêmicas e profissionais.

Ao Prof. Dr. Adilson Avansi de Abreu, por ter fomentado em mim o interesse no estudo da cratera de Colônia e de suas características geomorfológicas e por trazer valiosíssimas sugestões para a elaboração desta pesquisa.

Ao Prof. Dr. Ricardo Vicente Ferreira, por ter confiado em meu trabalho e no meu interesse pelo ensino da Geografia Física e por suas valiosas contribuições na elaboração desta pesquisa.

Ao Ms. Marcos Roberto Pinheiro, técnico do Laboratório de Pedologia da Universidade de São Paulo, com quem tive boas conversas a respeito do desenvolvimento desta pesquisa e de projetos futuros.

À Dra. Marisa de Souto Mator Fierz, técnica do Laboratório de Geomorfologia da Universidade de São Paulo, sempre solícita e disposta a me ajudar com sugestões e comentários.

Ao meu amigo Luís Filipe, que há mais de 16 anos me aconselha sabiamente e me apoia em minhas iniciativas. 
À minha namorada Carolina, por ter sido compreensiva e atenciosa nos momentos mais importantes de execução desta pesquisa.

Aos meus colegas do Departamento de Geografia da USP que me acompanharam nos trabalhos de campo e que fizeram indispensáveis comentários a esta pesquisa. Embora temeroso por eventuais e quase inevitáveis omissões injustas, não posso deixar de mencionar os nomes de: Katiúcia de Sousa Silva, Willian dos Santos, Newton Monteiro Campos Jr., Fernanda Volpon Neves, Vaniza Pasa, Paulo Gaudio Almeida e Luiz Barros.

Ao meu tio Magno, por ter sido meu principal apoiador no momento em que optei por cursar Geografia e por ter acompanhado entusiasticamente as etapas posteriores da minha carreira acadêmica, e que me forneceu importante material bibliográfico para a pesquisa.

A meus pais, Moacyr e Maria Cristina, que desde muito cedo me estimularam à leitura e ao interesse pela ciência, sem os quais nada deste trabalho seria possível. 


\section{RESUMO}

SANTOS, A. H. B. Condicionantes estruturais da drenagem e do relevo na cratera de Colônia e entorno, São Paulo-SP. 2013. 142 f. Dissertação (mestrado) - Faculdade de Filosofia, Letras e Ciências Humanas, Universidade de São Paulo, São Paulo, 2013.

A pesquisa tem como objetivo compreender a evolução da drenagem e do relevo na cratera de Colônia e entorno, no setor meridional do Planalto Paulistano, em São Paulo-SP. Parte-se da hipótese de que o relevo da área resulta da degradação de uma zona de estruturas concêntricas, formada em conjunto com a cratera, por impacto de bólido extraterrestre. Essas estruturas seriam atribuídas a um ou mais mecanismos, entre eles: a) controle exercido por um sistema de falhas radiais e concêntricos, b) estratificação do alvo, c) pico anelar em cratera complexa, d) ejecta fluidificada e e) fluidificação de finos, que resultaram na geração de uma zona de formas concêntricas no entorno da cratera. Após sua formação, o relevo da cratera e seu entorno foram degradados pela drenagem, que promoveu trabalho erosivo mais intenso a leste que a oeste, produzindo níveis hipsométricos menores a leste. Com base na proposta metodológica de Oliveira (2003), elabora-se uma descrição do relevo e da drenagem para identificar elementos sugestivos de condicionamento geológico produzido pela estrutura de impacto, por meio de fotointerpretação, trabalhos de campo e morfometria. A partir dos dados de hipsometria, rupturas de declividade e lineamentos da drenagem, descartam-se os mecanismos de estratificação do alvo, pico anelar e ejecta fluidificada, restando apenas o sistema de falhas radiais e concêntricos e a fluidificação de finos como possibilidades em aberto, cujo teste definitivo dependerá da disponibilidade de dados geofísicos detalhados. Os dados de morfometria, por sua vez, sugerem maior trabalho erosivo efetuado pelos rios da bacia do Jurubatuba que do Embu-Guaçu, respondendo pela assimetria altimétrica leste-oeste da zona de formas concêntricas e do anel colinoso da cratera de impacto e pela abertura da drenagem a leste, em conjunto com o condicionamento dado pelas linhas estruturais geradas tectonicamente. A presença de anomalias de drenagem e sua correlação com as integrais hipsométricas, por sua vez, são indicativas de modificação tectônica da drenagem, posterior à sua delineação condicionada pela estrutura de impacto.

Palavras-chave: cratera de impacto, condicionamento estrutural à drenagem, evolução do relevo, fotointerpretação, morfometria. 


\section{ABSTRACT}

SANTOS, A. H. B. Structural conditioning of drainage and relief in the Colônia crater and surrounding areas, São Paulo-SP. 2013. 142 f. Dissertação (mestrado) Faculdade de Filosofia, Letras e Ciências Humanas, Universidade de São Paulo, São Paulo, 2013.

This research aims to comprehend the relief and drainage evolution in the Colônia crater and surrounding areas, in the southern sector of the Paulistano Plateau, São Paulo-SP. We advance a hypothesis such as the morphology of the area results from degradation of a zone of concentric structures, originated at the same time as the crater, by extraterrestrial bolide impact. These structures are due to one or more mechanisms, among them: a) system of concentric and radial fractures, b) target stratification, c) peak ring in a complex impact structure, d) fluidized ejecta and e) fluidization of fine sediments, which generated a zone of concentric forms around the crater. After its formation, the relief of the crater and surroundings was degraded by drainage, which promoted a more intense erosive work to East than West, producing lower hypsometric levels to East. Based on the methodological proposal of Oliveira (2003), we elaborated a description of the topography and drainage to indentify suggestive elements for geological conditioning produced by the impact structure, by means of photointerpretation, fieldwork and morphometric measurements. From hypsometric data and slope break and drainage lineations analysis, we discard the hypothesis of: target stratification, peak ring and fluidized ejecta, leaving only those of concentric and radial fractures and fluidization of fine sediments, as open possibilities, whose final test will depend on the availability of detailed geophysical data. The morphometric data suggest greater erosive work performed by the Jurubatuba drainage basin than by Embu-Guaçu, responding by hypsometric East-West asymmetry of the crater's raised ring and surroundings. This still accounts for the position of its drainage exutory, to East, together with structural lines tectonically generated. The presence of drainage anomalies and their correlation with the hypsometric integrals are indicative of tectonic modification of drainage, after its delineation conducted by the impact structure.

Keywords: impact crater, structural conditioning to drainage, relief evolution, photointerpretation, morphometry. 


\section{SUMÁRIO}

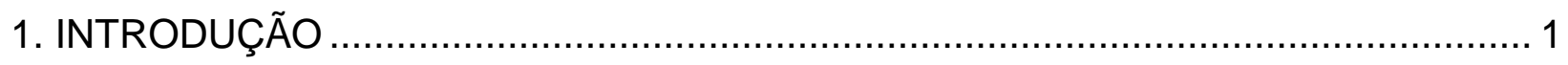

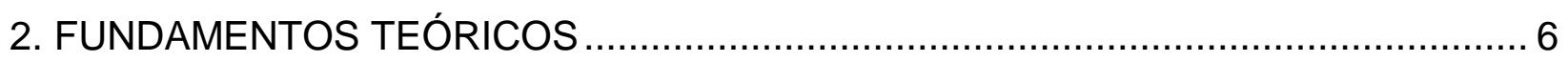

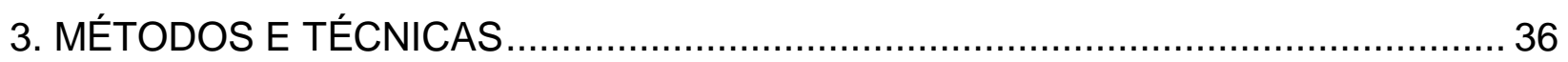

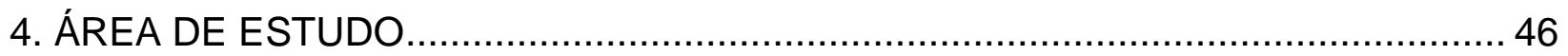

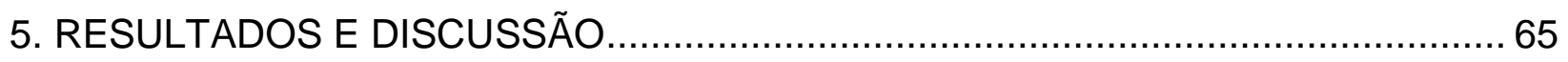

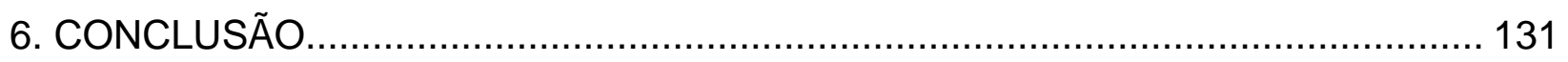

REFERÊNCIAS BIBLIOGRÁFICAS ....................................................... 133 


\section{SUMÁRIO EXPANDIDO}

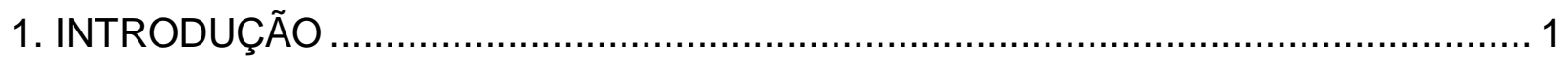

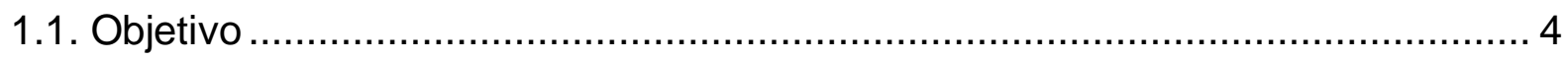

1.2. Justificativa

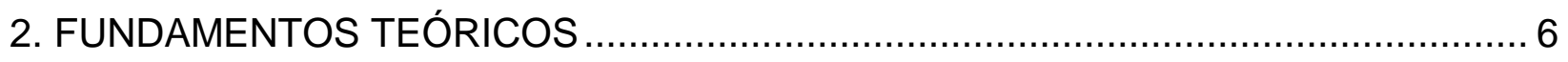

2.1. Breve histórico dos estudos de estruturas de impacto .................................... 6

2.2. O processo de craterização por impacto .................................................... 11

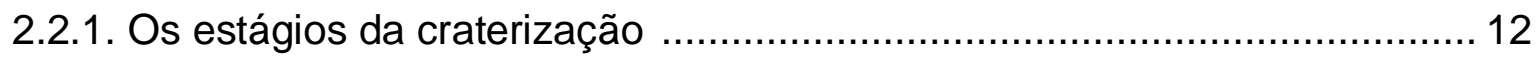

2.2.2. Impactos oblíquos e craterização …………...................................... 17

2.2.3. Diversidade morfológica de crateras de impacto .................................... 19

2.2.4. Impactos e estruturas concêntricas derivadas ...................................... 22

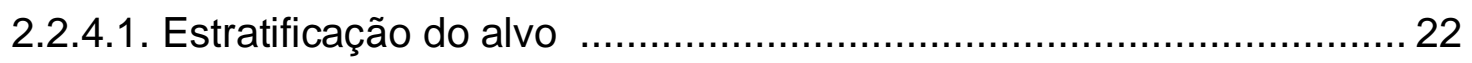

2.2.4.2. Pico anelar em crateras complexas ............................................ 24

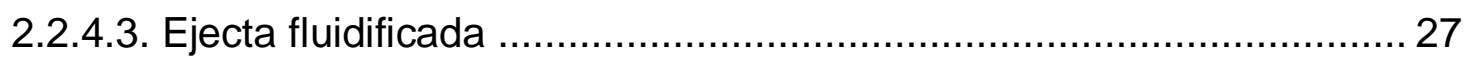

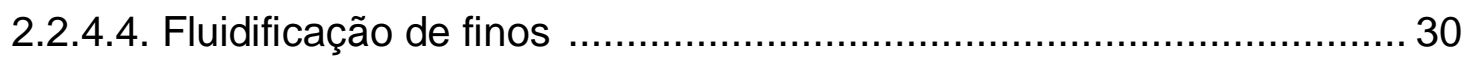

2.3. Degradação de estruturas de impacto e implicações geomorfológicas ............. 31

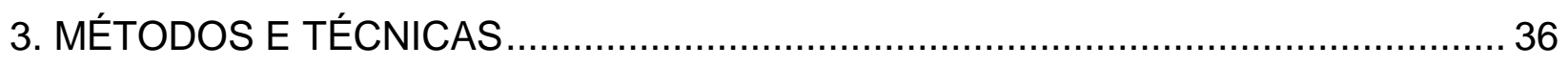

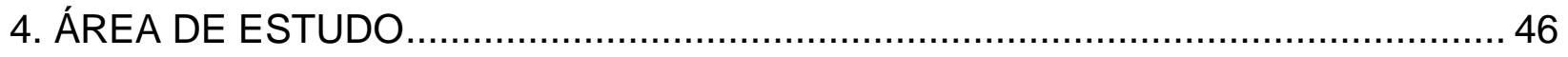

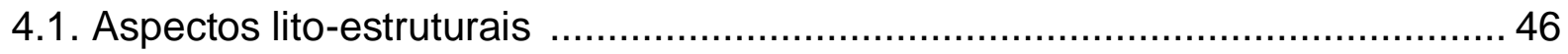


4.2. Aspectos climáticos e paleo-climáticos

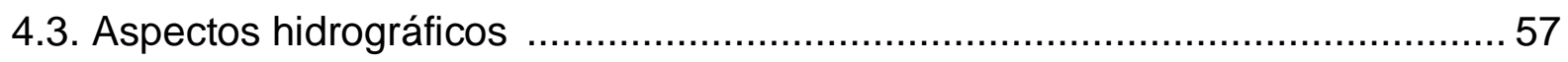

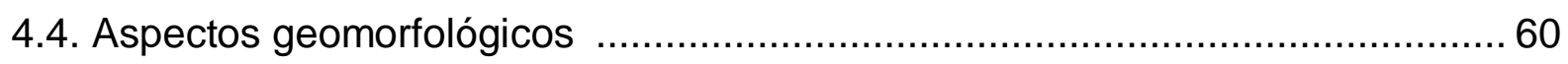

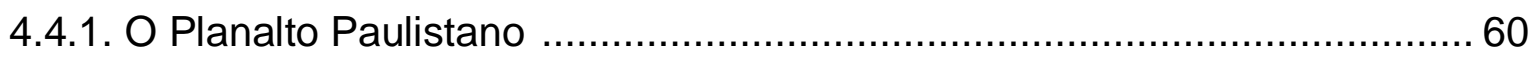

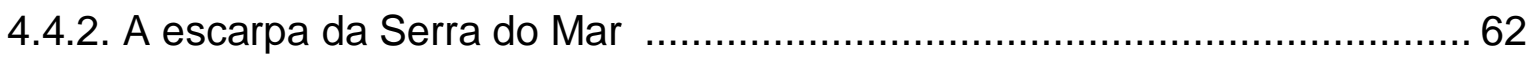

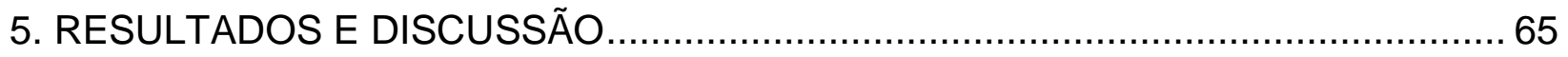

5.1. Observações gerais a respeito do relevo na região de Colônia ........................ 65

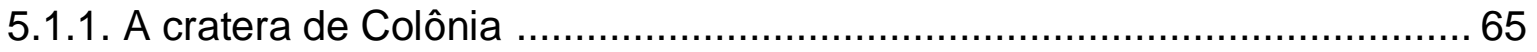

5.1.2. Colinas e morros da Zona de Formas Concêntricas à cratera de Colônia . 76

5.1.3. Compartimentos externos à Zona de Formas Concêntricas à cratera de Colônia

5.2. Possíveis mecanismos para a formação de uma zona de formas concêntricas

5.3. Desenvolvimento da drenagem e do relevo no entorno da cratera de Colônia. 96

5.3. Desenvolvimento da drenagem e do relevo no interior da cratera de Colônia 121

6. CONCLUSÃO 


\section{LISTAS DE ILUSTRAÇÕES}

\section{LISTA DE FIGURAS}

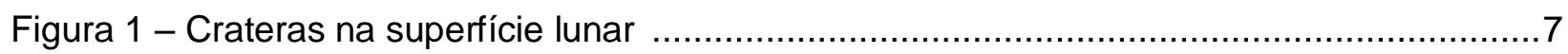

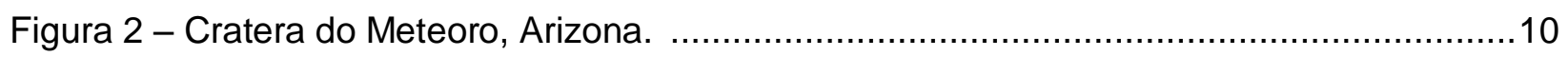

Figura 3 - Representação da formação de uma estrutura de impacto simples. .....................13

Figura 4 - Representação da formação de uma estrutura de impacto complexa...................15

Figura 5 - llustração esquemática exibindo as fraturas na borda da cratera do Meteoro ......... 16

Figura 6 - llustração esquemática mostrando resultado de experimentos de impactos oblíquos .

Figura 7 - Cratera de Ouarkziz, Argélia, exemplo de morfologia simples ............................21

Figura 8 - Cratera de Tin Bider, Argélia, exemplo de morfologia complexa .........................21

Figura 9 - A morfologia de crateras formadas em uma camada fraca sobrejacente a uma

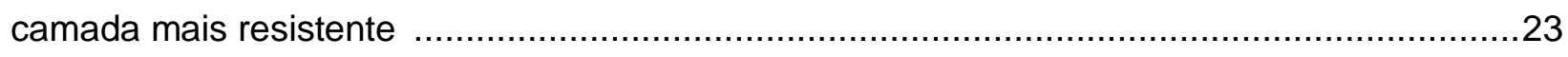

Figura 10 - llustração esquemática da formação de pico anelar (peak-ring) por colapso hidrodinâmico de um pico central excessivamente soerguido ..........................................26

Figura 11 - llustração esquemática da formação de pico central (central peak) e pico anelar (peak-ring) e do crescimento não-linear do volume de material fundido de impacto (impact melt) em relação ao crescimento do volume da cratera, conforme o modelo da Cavidade Fundida

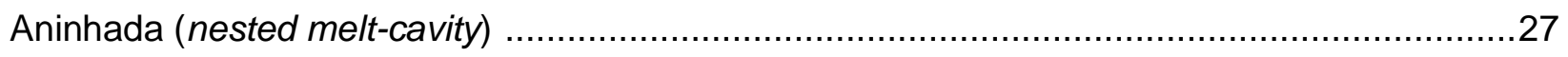

Figura 12 - Cratera de 9 km de diâmetro na Planitia Chryse, em Marte, com "rampart"

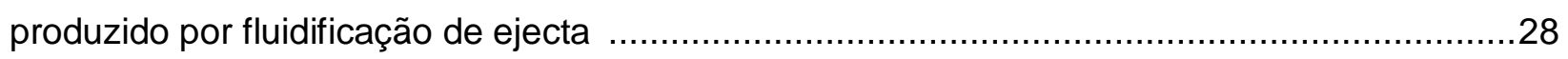

Figura 13 - Imagem de Radar, mostrando a estrutura Tsenkher, na Mongólia .....................29

Figura 14 - Cratera Prairie Flat, produzida experimentalmente a partir da detonação de 500 ton de TNT 31

Figura 15 - Cratera Kärdla, na Finlândia 32 
Figura 16 - Estrutura BP, na Líbia

Figura 17 - Identificação e articulação das fotografias aéreas utilizadas na pesquisa, pertencentes à coleção "Estado de São Paulo", de escala 1:25.000, obtidas em 1962 pela empresa "IA"

Figura 18 - Obtenção do Índice SL para um segmento de drenagem

Figura 19 - llustração esquemática da origem e do recuo erosivo da escarpa da Serra do Mar, conforme interpretação de Almeida e Carneiro (1998) 63

Figura 20 - Perfis geológicos radiais à cratera de Colônia .72

Figura 21 - Colinas de Embura (7), cujo relevo contrasta com o dos morros da Bacia do Rio Capivari (9), estes últimos muito mais dissecados, evidenciando controle litológico .84

Figura 22 - Anomalia Bouguer na região de Colônia, em mGal .95

Figura 23 - Modelo tridimensional da cratera de Colônia, obtido por análise de MDE de escala $1: 10.000$ 121

Figura 24 - Dimensões originais e atuais da Cratera de Colônia, conforme: relação empírica profundidade-diâmetro obtida por Grieve e Robertson (1979) e aplicada à cratera por Riccomini et al. (1991), dados geofísicos de profundidade do pacote sedimentar apresentados por Riccomini et al. (2011) e topografia atual 122

Figura 25 - Seção sudeste-noroeste da estrutura de Colônia, baseada em dados gravimétricos e áudio-magnetotelúricos obtidos por Motta e Flexor (1991) e Masero e Fontes (1991, 1992), respectivamente

Figura 26 - Perfil topográfico da cratera de Colônia, acrescido de dados magnetotelúricos e gravimétricos apresentados por Riccomini et al. (2001) 124

Figura 27 - Perfis longitudinais dos rios Embu-Guaçu e Jurubatuba e afluentes 126

Figura 28 - Curvas e integrais hipsométricas das bacias dos rios Embu-Guaçu, Jurubatuba e Capivari 127

Figura 29 - Lineamento topográfico, possivelmente relacionado a uma fratura que teria condicionado o posicionamento do exutório da drenagem da cratera de Colônia 128

Figura 30 - Vista aérea do exutório da drenagem da cratera de Colônia, sem a presença de cone de dejeção 130 


\section{LISTA DE GRÁFICOS}

Gráfico 1 - A relação entre o diâmetro do pico anelar (peak-ring) e a borda da cratera é constante nos planetas terrestres e o surgimento da feição é dependente da gravidade 25

Gráfico 2 - Estimativa de Magnitude-Frequência das chuvas no posto Paralheiros, município de São Paulo-SP, próximo à cratera de Colônia .56

Gráfico 3 - Percentagem de pólens arbóreos por profundidade, com indicação das datações obtidas por radiocarbono .57

Gráfico 4 - Lineamentos da rede de drenagem a norte da cratera ...................................... 101

Gráfico 5 - Lineamentos da rede de drenagem a oeste da cratera .....................................101

Gráfico 6 - Lineamentos da rede de drenagem a leste da cratera ........................................101

Gráfico 7 - Lineamentos da rede de drenagem a sul da cratera ..........................................101

Gráfico 8 - Lineamentos da rede de drenagem no entorno da cratera .................................102

Gráfico 9 - Direções das estruturas geológicas mapeadas (foliações e falhas) no entorno da

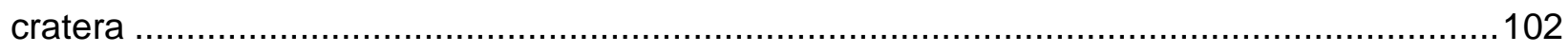

Gráfico 10 - Lineamentos topográficos na escala regional (1:50.000) …….........................102

Gráfico 11 - Perfil longitudinal (esquerda) e Índice SL do Rio 1, conforme Anexo 2 .............. 107

Gráfico 12 - Perfil longitudinal (esquerda) e Índice SL do Rio 2A, conforme Anexo 2 ........... 107

Gráfico 13 - Perfil longitudinal (esquerda) e Índice SL do Rio 2B, conforme Anexo 2 ............107

Gráfico 14 - Perfil longitudinal (esquerda) e Índice SL do Rio 3, conforme Anexo 2 ...............108

Gráfico 15 - Perfil longitudinal (esquerda) e Índice SL do Rio 4, conforme Anexo 2 ..............108

Gráfico 16 - Perfil longitudinal (esquerda) e Índice SL do Rio 5, conforme Anexo 2 ..............108

Gráfico 17 - Perfil longitudinal (esquerda) e Índice SL do Rio 6, conforme Anexo 2 ..............109

Gráfico 18 - Perfil longitudinal (esquerda) e Índice SL do Rio 7, conforme Anexo 2 ..............109

Gráfico 19 - Perfil longitudinal (esquerda) e Índice SL do Rio 8, conforme Anexo 2 ..............109

Gráfico 20 - Perfil longitudinal (esquerda) e Índice SL do Rio 9, conforme Anexo 2 ..............110

Gráfico 21 - Perfil longitudinal (esquerda) e Índice SL do Rio 10, conforme Anexo 2 ............110 
Gráfico 22 - Perfil longitudinal (esquerda) e Índice SL do Rio 11, conforme Anexo 2 110

Gráfico 23 - Perfil longitudinal (esquerda) e Índice SL do Rio 12, conforme Anexo 2 111

Gráfico 24 - Perfil longitudinal (esquerda) e Índice SL do Rio 13, conforme Anexo 2 111

Gráfico 25 - Perfil longitudinal (esquerda) e Índice SL do Rio 14, conforme Anexo 2 111

Gráfico 26 - Perfil hipsométrico da sub-bacia 1 117

Gráfico 27 - Perfil hipsométrico da sub-bacia 2 . 117

Gráfico 28 - Perfil hipsométrico da sub-bacia 3 117

Gráfico 29 - Perfil hipsométrico da sub-bacia 4 117

Gráfico 30 - Perfil hipsométrico da sub-bacia 5 . 117

Gráfico 31 - Perfil hipsométrico da sub-bacia 6 117

Gráfico 32 - Perfil hipsométrico da sub-bacia 7 118

Gráfico 33 - Perfil hipsométrico da sub-bacia 8 118

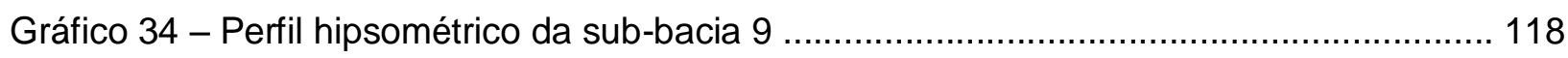

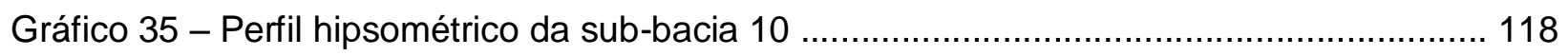

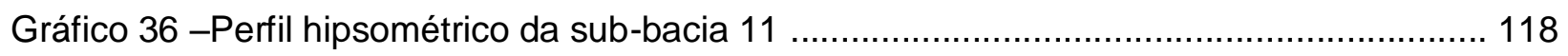

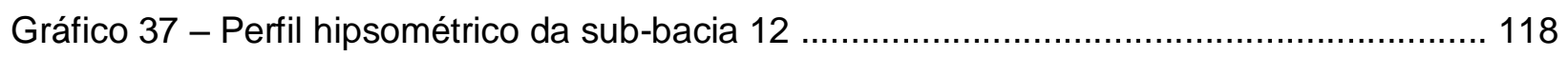

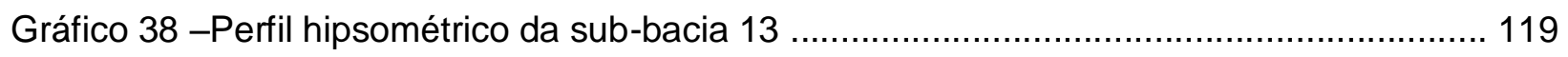

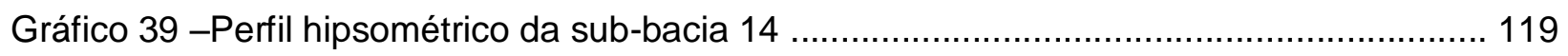

\section{LISTA DE QUADROS}

Quadro 1 - Simbologia adotada na Carta Morfológica e definições dos objetos mapeados .... 40

\section{LISTA DE MAPAS}

Mapa 1 - Localização da área de estudo, com elementos topográficos e planimétricos 47

Mapa 2 - Geologia da área de estudo sobreposta ao modelo sombreado 49

Mapa 3 - Climas naturais no Município de São Paulo .53 
Mapa 4 - Carta de isovalores da constante $Y$ da equação de estimativa da magnitudefrequência das precipitações na região de Parelheiros, São Paulo-SP

Mapa 5 - Carta de isovalores da constante A da equação de estimativa da magnitudefrequência das precipitações na região de Parelheiros, São Paulo-SP

Mapa 6 - Bacias hidrográficas dos rios Capivari, Embu-Guaçu e Jurubatuba, que drenam a superfície da cratera de Colônia e de terrenos adjacentes .58

Mapa 7 - Compartimentos geomorfológicos da região de São Paulo e arredores, conforme Ross e Moroz (1997) 61

Mapa 8 - Carta hipsométrica sobreposta ao modelo sombreado ...................................66

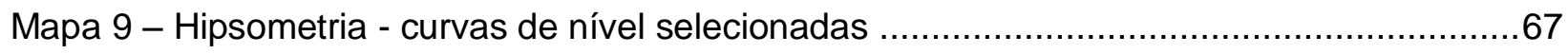

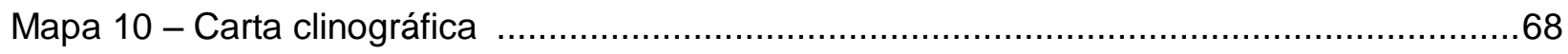

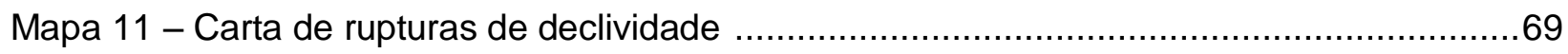

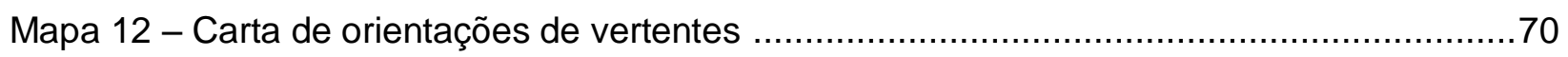

Mapa 13 - Delimitação esquemática dos alinhamentos topográficos altos e baixos

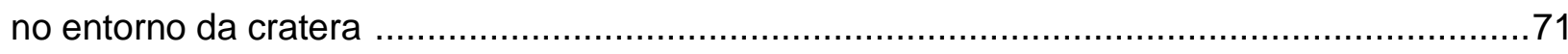

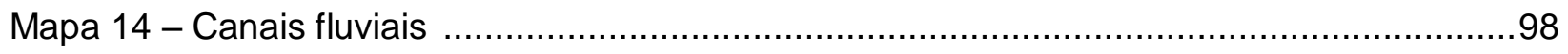

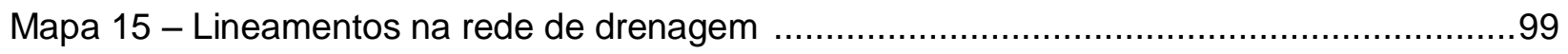

Mapa 16 - Carta de lineamentos topográficos sobreposta ao modelo sombreado ................100

Mapa 17 - Canais fluviais paralelos e radiais à borda da cratera .................................... 103

Mapa 18 - Canais fluviais paralelos e radiais à borda da cratera, sem representação dos

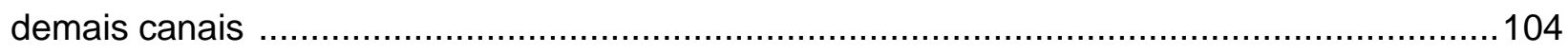

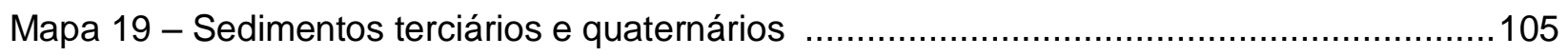

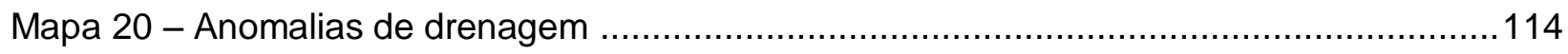

Mapa 21 - Integrais hipsométricas das sub-bacias de 4ª ordem que drenam a zona de formas

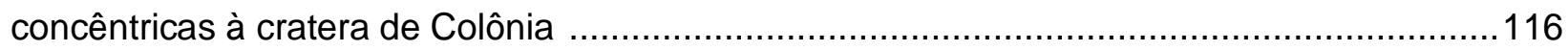

Mapa 22 - Densidades de drenagem das sub-bacias de $4^{\text {a }}$ ordem que drenam a zona de formas concêntricas à cratera de Colônia ..................................................................... 120 


\section{LISTA DE FOTOS}

Foto 1 - Interior da cratera de Colônia, visto a partir da borda meridional ................................73

Foto 2 - Fragmento do anel colinoso, na borda meridional da cratera de Colônia ....................75

Foto 3 - Exterior da cratera de Colônia, visto a partir do segmento setentrional de seu anel colinoso

Foto 4 - Paisagem no Setor Ocidental da Zona de Formas Concêntricas à Cratera, exibindo forte dissecação, topos convexos e vales em "V", a partir da Estrada de Marsilac .79

Foto 5 - Vista panorâmica da paisagem no Setor Meridional da Zona de Formas Concêntricas, em Marsilac, na qual se observa forte dissecação do relevo, topos convexos e aguçados e cobertura vegetal densa 80

Foto 6 - Paisagem no Setor Meridional da Zona de Formas Concêntricas, às margens da Represa Billings, na qual se observa menor dissecação do relevo, com formação de vales mais amplos e drenagem mais livre .81

Foto 7 - Vista geral da Planície do Ribeirão Embura, delimitada pela unidade meridional da Zona de Formas Concêntricas (à esquerda) e pelas Colinas de Embura (à direita) .85

Foto 8 - Afloramento de arenito fraturado sob material detrítico provavelmente transportado 115 Foto 9 - Exutório da drenagem da cratera de Colônia, sem a presença de cone de dejeção 129 


\section{INTRODUÇÃO}

O relevo terrestre é compreendido pelo sistema geomorfológico Penckiano enquanto produto da interação entre processos endógenos - originados da dinâmica interna da Terra - e exógenos - originados a partir de sua dinâmica externa (PENCK, 1953). O substrato geológico, ou arcabouço lito-estrutural, deforma-se devido a esse campo de tensões para produzir o relevo, condicionando o seu desenvolvimento. Esse condicionamento é normalmente referido pelo termo "controle geológico" do relevo.

Os processos fluvialmente controlados contribuem para a esculturação do relevo terrestre, de tal modo que o controle geológico do relevo se faz, em grande medida, por meio do controle geológico da rede de drenagem. As águas superficiais, ao procurarem o caminho mais curto até o centro de gravidade do planeta, deslocam os produtos intemperizados do substrato geológico, mais facilmente remobilizados e frequentemente disponíveis ao longo de suas principais linhas de fraqueza, estruturalmente produzidas.

Para Morisawa (1985), o controle geológico da drenagem é classificado em estrutural e litológico. Conforme a autora, o controle estrutural é dinâmico, quando falhas, dobras e mudanças de inclinação da superfície se formam pela tectônica atual; ou passivo, quando tais feições se encontram formadas por processos pretéritos. Já o controle litológico é aquele exercido pela composição das rochas, importante por controlar a resistência das mesmas ao intemperismo e à erosão.

Em função dos processos que as originaram, as estruturas geológicas se organizam assumindo diferentes disposições espaciais, o que leva a diferentes padrões de drenagem (TWIDALE, 2004). As fraturas produzidas tectonicamente assumem formas retilíneas ou curvas, de acordo com os campos de tensão atuantes e a resistência dos materiais litológicos. Outras estruturas normalmente se dispõem de maneira circular - como as fraturas geradas por eventos diapíricos ou intrusivos, ou ainda por impactos meteoríticos (PRICE e COSGROVE, 1990). Essa diversidade de arranjos estruturais é responsável pela grande variedade de padrões de drenagem observada na superfície da Terra. 
Estruturas circulares são amplamente distribuídas pelo planeta e se formam por processos endógenos, como diapirismo e vulcanismo, ou exógenos, como impactos de bólidos extraterrestres. Muitas delas constituem heranças na paisagem, marcando processos já ocorridos e não mais em andamento, mas persistem condicionando o desenvolvimento do relevo e da drenagem atuais devido às deformações produzidas nas rochas. Impactos meteoríticos são excelentes exemplos de eventos que ocorrem quase instantaneamente, mas persistentes em suas consequências na paisagem.

A feição circular motivadora deste trabalho é a cratera de Colônia, localizada na região de Parelheiros, próxima à escarpa da Serra do Mar em São Paulo (SP). Com 3,6 km de diâmetro e forte circularidade, essa feição geomorfológica chama a atenção de pesquisadores de diversas áreas, entre astrônomos, geólogos, geofísicos, geógrafos e biólogos.

A cratera de Colônia foi identificada por meio de levantamentos aerofotogramétricos e no primeiro trabalho a respeito de sua origem (KOLLERT et al.,1961) foram levantadas duas hipóteses: dissolução de calcário e queda de meteorito, com preferência pela última. Já Riccomini et al. (1992) testaram diversas hipóteses alternativas, como tectonismo, intrusão, escorregamento de grandes proporções e dissolução de calcário, concluindo ser mais provável a origem por impacto, por falta de evidências dos processos anteriores. No entanto, reconheceram a impossibilidade de concluir definitivamente pela origem por impacto, uma vez que não havia sido identificados produtos de metamorfismo de choque.

Estudos geofísicos realizados na cratera de Colônia, como os de Motta e Flexor (1991) e Neves (1998), sugerem profundidades de 250 a 350 metros para o contato entre o pacote sedimentar e o embasamento. Riccomini et al. (2011) consideram essa profundidade menor que a esperada para uma cratera de impacto simples, a partir da relação profundidade-diâmetro identificada por Grieve e Robertson (1979). Assumindo sua origem por impacto, os autores procuram justificar sua menor profundidade em função de parâmetros relacionados ao bólido - como composição, tamanho, velocidade e ângulo do impacto - ou, principalmente, da profundidade atingida pela erosão da estrutura, tendo em vista que a formação da cratera de Colônia ocorreu durante o soerguimento da escarpa da Serra do Mar. 
A idade da cratera de Colônia ainda não foi precisamente determinada. Para Riccomini et al. (2005), a idade eocênica a oligocênica dos sedimentos arenoargilosos da Formação Resende, presentes na crista da cratera, balizaria o limite máximo de sua idade. Já Ledru et al. (2005), extrapolando a taxa de sedimentação inferida a partir da datação dos primeiros $7,8 \mathrm{~m}$ do pacote sedimentar da cratera, calcula que foram necessários aproximadamente 2,5 Ma para o preenchimento da cavidade, desconsiderando os efeitos da compactação e de inconformidades dentro da sucessão sedimentar. Partindo do estado de preservação da morfologia da cratera, em comparação com outras estruturas de idades conhecidas, Riccomini et al. (2011) sugerem um intervalo de 36 e 5 Ma sua idade. No entanto, reconhecem que a idade da estrutura deverá ser determinada mais precisamente a partir de estudos palinológicos ou de materiais produzidos por fusão no momento de sua formação.

Recentemente, Velazquez et al. (2013) realizaram sondagens no pacote sedimentar da cratera de Colônia e identificaram feições de metamorfismo de choque, como deformação planar em cristais de quartzo, feldspato e mica; textura granular em zircônio; e rochas com indícios de fusão por impacto. Deste modo, estabelece-se sua origem por impacto e a cratera de Colônia passa a integrar o grupo das seis crateras de impacto confirmadas no Brasil e das 184 crateras de impacto confirmadas no mundo (PASSC, 2013).

Nota-se, no entorno da cratera, um conjunto de vales e cristas dispostos de maneira radial e concêntrica em relação àquela. Esse conjunto de feições, bastante "camuflado", é de difícil identificação em campo e no exame visual de fotografias aéreas. Com $9 \mathrm{~km}$ de diâmetro e centrada na cratera, essa região de formas concêntricas não é mencionada nos trabalhos acadêmicos sobre a cratera de Colônia - seja por se tratar de uma feição pouco evidente para ser notada - seja por se tratar de um mero artefato produzido pela combinação das estruturas geológicas existentes no entorno da cratera.

A origem e a evolução dessa zona de formas radiais e concêntricas, a evolução geomorfológica da cratera de Colônia e o vínculo genético entre as duas feições constituem a problemática dessa pesquisa. 


\subsection{OBJETIVO}

O objetivo da pesquisa é produzir conhecimentos a respeito da evolução da drenagem e do relevo na cratera de Colônia e em seu entorno, buscando evidências de possível condicionamento estrutural. Para tanto, elabora-se uma caracterização detalhada da morfologia e da drenagem da área, reunindo-se também dados a respeito da evolução geológica contemporânea à evolução da cratera.

Parte-se da hipótese de que a drenagem e o relevo da área foram produzidos a partir da degradação de uma superfície original composta de formas radiais e concêntricas à cratera de Colônia, sustentada por litologias deformadas na ocasião do impacto de bólido extraterrestre. Essa degradação foi conduzida pelas características da superfície prístina e das estruturas geológicas formadas, bem como pela atividade tectônica pós-impacto e variabilidade temporal e espacial da atividade erosiva fluvial.

Essa estrutura, constituída por feições concêntricas, seria atribuída a um ou mais mecanismos, entre eles: controle exercido por um sistema de falhas radiais e concêntricos, estratificação do alvo, pico anelar em cratera complexa, ejecta fluidificada e fluidificação de finos. Ressalta-se, ainda a possibilidade de a morfologia da área ter outras origens, além das listadas.

Sugere-se que a degradação do conjunto concêntrico à cratera ocorreu de maneira desigual, com maior intensidade a leste que a oeste. Em consequência, os cumes das colinas e morros presentes no setor oriental da estrutura encontram-se mais rebaixados que os do setor ocidental, o que corresponde à forma do próprio anel soerguido da cratera, mais rebaixado a leste que a oeste, influenciando ainda na posição do exutório de sua rede fluvial, também a leste.

\subsection{JUSTIFICATIVA}

A escassez de trabalhos na Geomorfologia que tratam de crateras de impacto constitui a maior motivação para a pesquisa. Normalmente essas estruturas são estudadas por geólogos e geofísicos, com suas problemáticas próprias.

Justifica-se a seleção da área de estudo por sua importância científica e ambiental, além de sua acessibilidade, em pleno município de São Paulo. Riccomini 
et al. (1992) consideram que a cratera de Colônia representa um sítio promissor às pesquisas científicas, para o entendimento do processo que a originou e pela existência de um pacote sedimentar espesso muito favorável para pesquisas do Quaternário.

A cratera se encontra em área de mananciais com remanescentes de Mata Atlântica, o que Ihe atribui destacado valor ecológico, reconhecido pelo Estado na medida em que existem áreas de proteção ambiental (APA Capivari-Monos, criada em 2001) e leis (Lei de Proteção aos Mananciais de 1975) que regulamentam o uso do solo visando sua preservação. Encontram-se na área as bacias dos rios EmbuGuaçu e Jurubatuba, nas quais se encontram, respectivamente, as represas Guarapiranga e Billings, que abastecem grande parte da população da cidade de São Paulo.

Dada sua relevância interdisciplinar, o poder público visa garantir a proteção a cratera de Colônia por uma série de instrumentos e mecanismos, como: o tombamento pelo Conselho de Defesa do Patrimônio Histórico, Arqueológico, Artístico e Turístico (CONDEPHAAT) em 2003; o reconhecimento enquanto Sítio Geológico pela Comissão Brasileira de Sítios Geológicos e Paleontológicos (SIGEP) em 2005; a criação do Parque Natural Municipal da Cratera de Colônia, em 2007; o reconhecimento enquanto Monumento Geológico por meio do Conselho Estadual de Monumentos Geológicos (CoMGeo-SP) - 2009. A Cratera de Colônia é um dos cinco monumentos geológicos paulistas, juntamente com o PETAR, o Varvito de Itu, a Rocha Mountonné e os Geiseritos de Anhembi. 


\section{FUNDAMENTOS TEÓRICOS}

Estrutura de impacto é o nome dado a uma estrutura geológica formada por impacto de bólido extraterrestre, seja ele um meteoroide, um asteroide ou um cometa, contra um alvo, no caso a superfície da Terra. A estrutura também pode ser referido pelo termo "astroblema" (DIETZ, 1963). No entanto, o termo não recebeu uso geral na literatura internacional (GRIEVE, 1993), levando à opção, neste trabalho, por "estrutura de impacto".

À feição crateriforme sustentada por essa estrutura atribui-se o nome "cratera de impacto". Por vezes, a cratera de impacto é ausente, devido à sua remoção por processos endógenos e exógenos, restando apenas a estrutura de impacto e sua assinatura geofísica na forma de uma anomalia gravimétrica negativa (NEVES, 1998).

O impacto de bólidos extraterrestres é processo fundamental na evolução da Terra e de outros corpos do Sistema Solar (SHOEMAKER, 1977). Entretanto, a ampla aceitação deste processo ocorreu apenas a partir dos anos 1960, após três séculos de debates, nos quais predominou a posição de incredulidade e de ridicularização diante da hipótese meteorítica e favorecimento da hipótese vulcânica para explicar estruturas circulares duvidosas (HOYT, 1987).

\subsection{BREVE HISTÓRICO DOS ESTUDOS DE ESTRUTURAS DE IMPACTO}

Os estudos sobre estruturas de impacto desenvolveram-se a partir de três áreas inicialmente independentes: estudos de crateras lunares, experimentos envolvendo grandes explosões com finalidade militar e estudos de meteoritos localizados na Terra (MELOSH, 1989).

Nos estudos de crateras lunares, um grupo majoritário de especialistas, dos quais se mencionam J. H. Schröter, E. Neison, J. D. Dana, J. Nasmyth e J. Carpenter, sustentou a hipótese vulcânica para explicar as frequentes crateras, sugerindo perda rápida de calor devido ao reduzido tamanho do satélite, desencadeando vulcanismo de proporções catastróficas. Outro grupo de cientistas, cada vez mais influente, não aceitou essa explicação e propôs origem por impacto, como F. P. Gruithusen, R. A. 
Proctor e G. K. Gilbert, ao notar disparidades morfológicas entre crateras lunares e vulcões terrestres (HOYT, op cit, p. 7-30).

Grande obstáculo à hipótese dos impactos, na época, consistiu na circularidade geral das crateras (Figura 1), a despeito da distribuição aleatória das direções de proveniência dos bólidos, o que a priori deveria refletir na elipticidade da maioria delas. Öpik (1916) apud Hoyt (1987, p. 196), para resolver o problema, propôs que a circularidade geral das crateras de impacto seria decorrente das velocidades cósmicas dos meteoritos, levando à liberação de enormes quantidades de energia, de maneira repentina. Essa liberação de energia ocorreria por intermédio de uma explosão, produzindo crateras circulares independentemente do ângulo de incidência.

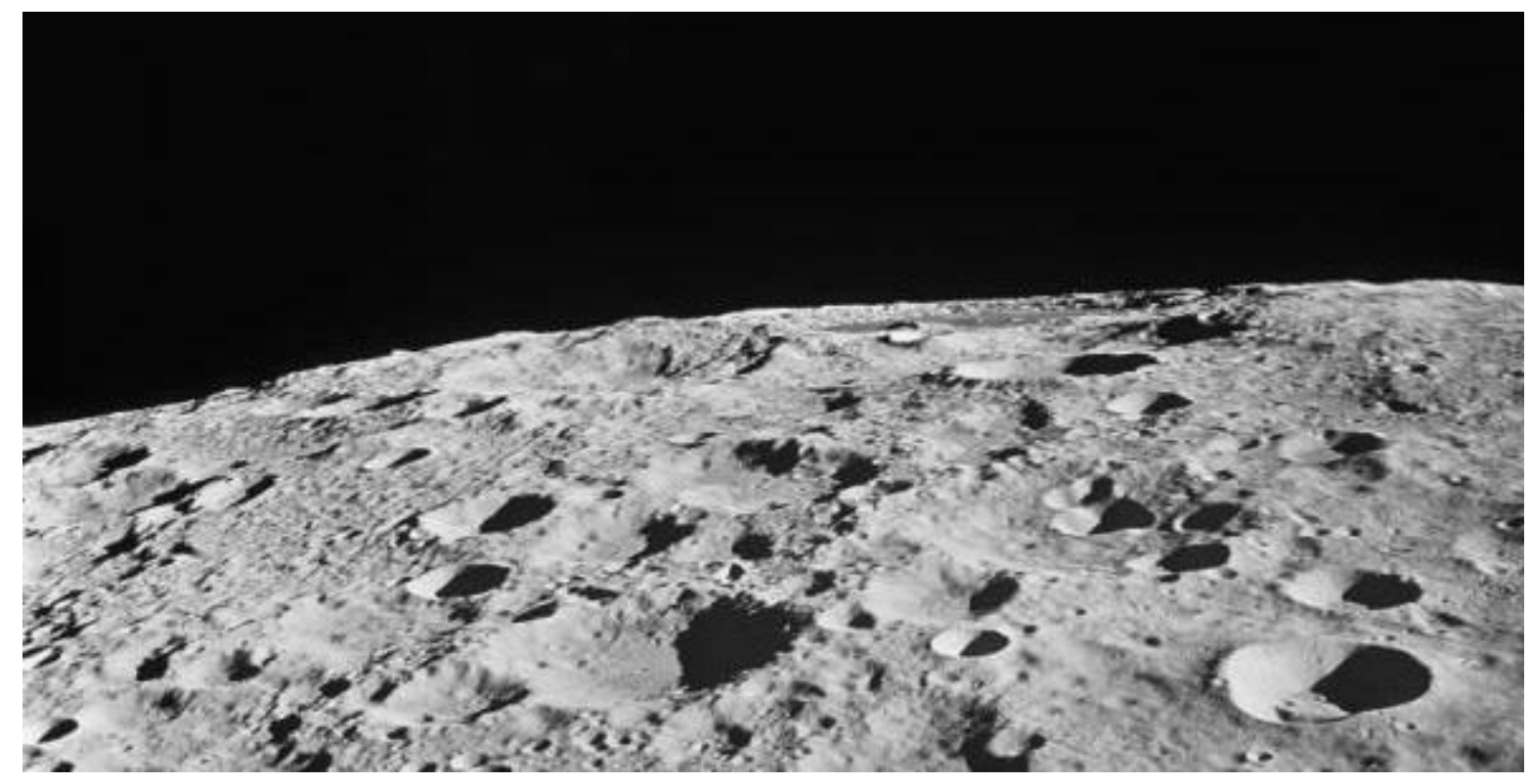

Figura 1 - Crateras na superfície lunar: alvo de discórdias entre proponentes da teoria vulcânica e da teoria meteorítica. Fonte: http://mix.msfc.nasa.gov. Acesso em 10 mar 2012.

Os "vulcanistas" reagiram argumentando sobre a inexistência de feições de impacto meteorítico na Terra. Tal argumentação perdeu validade a partir da confirmação da origem por impacto da cratera do Meteoro, no Arizona, por D.M. Barringer na década de 1920, além do reconhecimento de outras crateras contendo evidências de metamorfismo de choque na Terra (HOYT, op cit, p. 212).

Embora a quantidade de crateras de impacto reconhecidas na Terra seja menor que na Lua (pouco mais de 180 contra milhares), o fluxo de impactos em nosso 
planeta foi muito maior por sua maior atração gravitacional. No entanto, processos tectônicos e denudacionais contribuíram para eliminar a maioria dos vestígios de impactos meteoríticos antigos (TREFIL e RAUP, 1990).

Os estudos a respeito de crateras lunares tiveram grande impulso com investigações geológicas de suas análogas terrestres. Levantamentos por sensoriamento remoto com resolução cada vez maior e as missões Apolo, com retorno de amostras lunares, convenceram a maior parte dos cientistas de que as crateras lunares têm origem por impacto, bem como a de outros corpos do Sistema Solar, como Mercúrio, Vênus, Marte e satélites de Júpiter, Saturno, Urano e Netuno (MELOSH, 1989, p.13).

A segunda frente de estudos - de natureza experimental - também teve importância no entendimento do processo de formação de crateras de impacto, uma vez que grandes colisões (capazes de produzir crateras de mais de $1 \mathrm{~km}$ de diâmetro) jamais foram testemunhadas. Mc Call (2009) discute a importância dos experimentos e alerta para o problema da reprodução das escalas e das grandes velocidades envolvidas.

Knowles e Brodes (1977) destacaram diferenças fundamentais entre explosões nucleares e impactos meteoritos, como as maiores temperaturas e predominância da radiação nos estágios iniciais da formação de crateras nas primeiras. Essas diferenças exigem ajustes teóricos, mas não invalidam as analogias entre as explosões quanto à pressões envolvidas e as translocações de materiais.

Roddy (1977), porém, destacou que simulações em grandes escalas não são possíveis e que há dependência da extrapolação de dados experimentais, já que testes nucleares foram banidos pelo Tratado de Banimento de Testes de Armas Nucleares na Atmosfera, no Espaço Exterior e sob as Águas, assinado por 113 países.

Para Cooper Jr. (1977), os estudos experimentais devem anteceder tratamentos numéricos do processo de formação de crateras de impacto, para que haja bases concretas nesses estudos. Em seu artigo, discutiu mecanismos de craterização explosiva (explosive cratering) e fenômenos relacionados, a partir de fontes altamente explosivas (high explosive - HE) e fontes de explosão nuclear (nuclear explosive - NE). Envolvendo pressões semelhantes às de impactos 
meteoríticos, estudos de explosões nucleares forneceriam informações confiáveis, permitindo modelagem do processo.

A terceira frente de estudos diz respeito a crateras terrestres. Os relatos a respeito da queda de objetos de origem cósmica na Terra eram pouco aceitos por filósofos e cientistas até a constatação, no início do séc. XIX, de que há objetos no espaço que ocasionalmente atingem a Terra em alta velocidade, após uma queda de meteoritos ter sido testemunhada pela população em L'Aigle, na França (MELOSH, 1989, p. 6). No Arizona, pela primeira vez, estabeleceu-se a relação entre esses objetos e uma cratera, o que deu início há uma série de debates. Hoyt (1987) discute as controvérsias sobre a origem da estrutura de "Coon Mountain", no Arizona, a primeira cratera de impacto identificada na Terra e a mais intensamente estudada, atualmente denominada cratera do Meteoro ou cratera de Barringer, com aproximadamente 1,1 km de diâmetro (Figura 2).

G. K. Gilbert foi o primeiro cientista a se interessar pela origem da referida cratera e formulou duas hipóteses: explosão de gases subterrâneos ou impacto meteorítico. Esperando comprovar origem meteorítica da cratera, Gilbert postulou a existência de um grande corpo ferrífero enterrado sob a cratera e que sua existência se manifestaria de duas formas: pelo menor volume da cavidade que da crista da cratera e pela anomalia magnética que seria produzida. Ao realizar testes em campo, obteve resultados negativos e concluiu pela origem da cratera por explosão de gases (GILBERT, 1895 apud HOYT, op cit, p. 48-53).

D. M. Barringer, engenheiro de minas, também se interessou pela cratera, entre as décadas de 1900 e 1920, logo se convencendo de sua origem meteorítica e da existência de um grande corpo ferrífero ali enterrado. Buscando provar a origem proposta e ter acesso a lucrativas jazidas de ferro, fez perfurações e atingiu fragmentos meteoríticos, interpretados por ele como a extremidade superior da massa meteorítica. No entanto perfurações subsequentes levaram à constatação de que se tratam apenas de pequenos fragmentos e não de uma grande massa, frustrando seus interesses comerciais. Ainda assim, Barringer foi reconhecido por ter identificado, pela primeira vez, uma cratera de impacto terrestre (HOYT, op cit, p. 318).

Novas crateras e estruturas similares foram identificadas nas duas décadas subsequentes (Steinheim, Ries, Kentland, Upheaval Dome e Crooked Creek - as duas primeiras na Alemanha, as três últimas nos Estados Unidos). Para Bucher (1936), elas 
teriam origem criptovulcânicas, ou seja, formadas por um tipo de "vulcanismo abortado", com ocorrência de uma violenta liberação de gases, sem extrusão correspondente de material magmático.

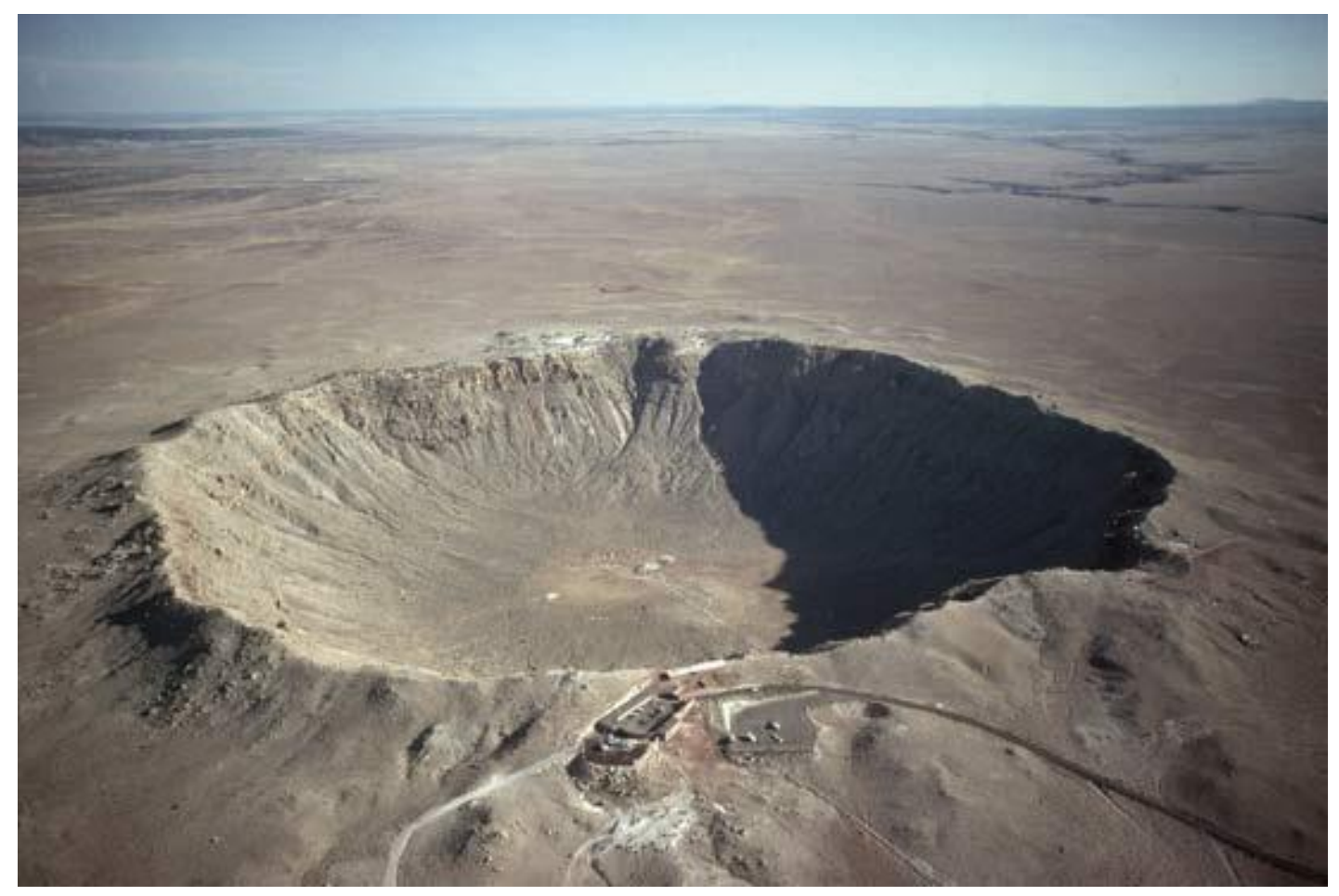

Figura 2 - Cratera do Meteoro, Arizona. Primeira feição terrestre a ser reconhecida como cratera de impacto, por D.M. Barringer, na década de 1910. Fonte: http://cometasite.ru/. Acesso em 8 abr 2013.

Dietz (1959) rejeitou a ideia do criptovulcanismo para explicar essas estruturas e propôs que as mesmas tiveram origem por impacto meteorítico, com base na ocorrência de cones de estilhaçamento. Esses fragmentos rochosos possuem estrias retilíneas que convergem para um ápice que aponta para o centro da cratera e somente seriam possíveis após eventos de altíssima pressão.

O número de crateras de impacto terrestres identificadas e reconhecidas cresceu com o progresso dos estudos: Grieve e Robertson (1979) apresentaram uma lista com as 13 crateras de impacto reconhecidas no mundo em sua época, com evidências de metamorfismo de impacto (polimorfos de alta pressão do quartzo: coesita e stishovita, além de cones de estilhaçamento). Onze anos depois, Trefil e Raup (1990) contabilizaram 110 crateras de impacto; Grieve e Pesonen (1992) 
listaram 130 e French e Koeberl (2010) mencionaram a existência de 175 delas. Possivelmente, há muitas outras crateras a serem descobertas: para Trefil e Raup (op cit), apenas $6 \%$ de todas as crateras de impacto existentes no planeta foram identificadas, restando aproximadamente cerca de 1800 crateras, muitas delas em estágio mais avançado de degradação.

A partir do desenvolvimento dos estudos lunares, da execução de testes experimentais e da identificação de diversas estruturas de impacto na Terra, a hipótese meteorítica deixou de ser rejeitada para tornar-se amplamente reconhecida (DIETZ, 1963). A constatação de que grandes impactos meteoríticos participaram de eventos de extinção em massa, como o evento K/T (ALVAREZ et al., 1995), aumentou o interesse pelo estudo desses fenômenos.

Para French e Koeberl (op cit), o entusiasmo recente por impactos meteoríticos entre cientistas levou à proliferação de registros incorretos ou questionáveis de estruturas de impacto, sendo necessário haver um critério bem definido para identificá-las. Consideram-se feições diagnósticas de impacto: fragmentos meteoríticos preservados, assinaturas químicas e isotópicas do projétil, cones de estilhaçamento, vidros minerais (diapléticos) de alta pressão, fases minerais de alta pressão, vidros e melts (rochas fundidas) de altas temperaturas, fraturas planares em quartzo (PFs), feições planares de deformação (PDFs). Já a morfologia circular, deformação estrutural circular, anomalias geofísicas circulares, fraturas, brechas, kink banding em micas, mosaicismo em cristais, pseudotaquilitos, brechas pseudotaquilíticas, rochas ígneas, vidros, esférulas e microesferulas são feições nãodiagnósticas.

\subsection{O PROCESSO DE CRATERIZAÇÃO POR IMPACTO}

O termo impact cratering, traduzido para o português como "craterização" (POMEROL et al., 2013, p. 40), foi utilizado pela primeira vez para explicar os processos envolvidos na formação das feições estruturais da cratera do Meteoro, no Arizona (DENCE, 1972). Define-se como processo desencadeado a partir do momento em que um bólido extraterrestre em hipervelocidade (supersônico) chocase com a Terra, provocando liberação de grande quantidade de energia em curto intervalo de tempo e espaço muito limitado (FRENCH e KOEBERL, 2010). Se o corpo 
possui massa e coesão suficientes, ele vence a resistência atmosférica e mantém a hipervelocidade até colidir com a superfície (FRENCH, 1998).

\subsubsection{Estágios da craterização}

No processo de craterização, ocorre uma sequência rápida de eventos, produzindo ao final uma estrutura de impacto - do ponto de vista geológico - e uma cratera de impacto - do ponto de vista geomorfológico. Gault et al. (1968) propõem o agrupamento desses eventos em três estágios, cada um dominado por diferentes condições físicas: estágio de contato e compressão, estágio de escavação e estágio de modificação (Figura 3). Para Melosh (1989, p. 46), a divisão não é rígida e o processo deve ser entendido como um conjunto contínuo de fenômenos.

O bólido, antes de atingir a superfície, encontra a atmosfera planetária e forte atrito é gerado, ocasionando sua desaceleração, seu aquecimento e, eventualmente, sua fragmentação. Parte do bólido é fundida e parte é vaporizada, formando uma cauda incandescente. A fragmentação do bólido pode formar um agrupamento de crateras, como em Campo del Cielo, na Argentina (SCHULTZ e LIANZA, 1992). Estimativas superestimadas quanto ao papel da atmosfera na desaceleração do projétil contribuíram para Barringer acreditar na existência de grandes remanescentes meteoríticos sob a cratera do Meteoro, no Arizona, pois um impacto em baixa velocidade tornaria possível a preservação de grande proporção de sua massa (HOYT, 1987, p. 73-99).

Quando o bólido atinge a superfície, inicia-se o estágio de contato e compressão, com duração de alguns décimos de segundo, até sua total destruição. $O$ bólido penetra a uma profundidade de no máximo o dobro de seu próprio diâmetro (FRENCH, op cit). Grande parte de sua energia cinética é transferida para o alvo, provocando compressão, aquecimento e aceleração dos constituintes deste último. Ao mesmo tempo, a resistência do alvo à penetração produz desaceleração do projétil. Mudanças bruscas de velocidade são mediadas pela formação de ondas de choque, que se propagam tanto para o alvo quanto para o projétil, em velocidade supersônica. As pressões envolvidas em um impacto excedem a resistência dos materiais constituintes da crosta terrestre, provocando a destruição dos mesmos (MELOSH, op cit, p. 40). 


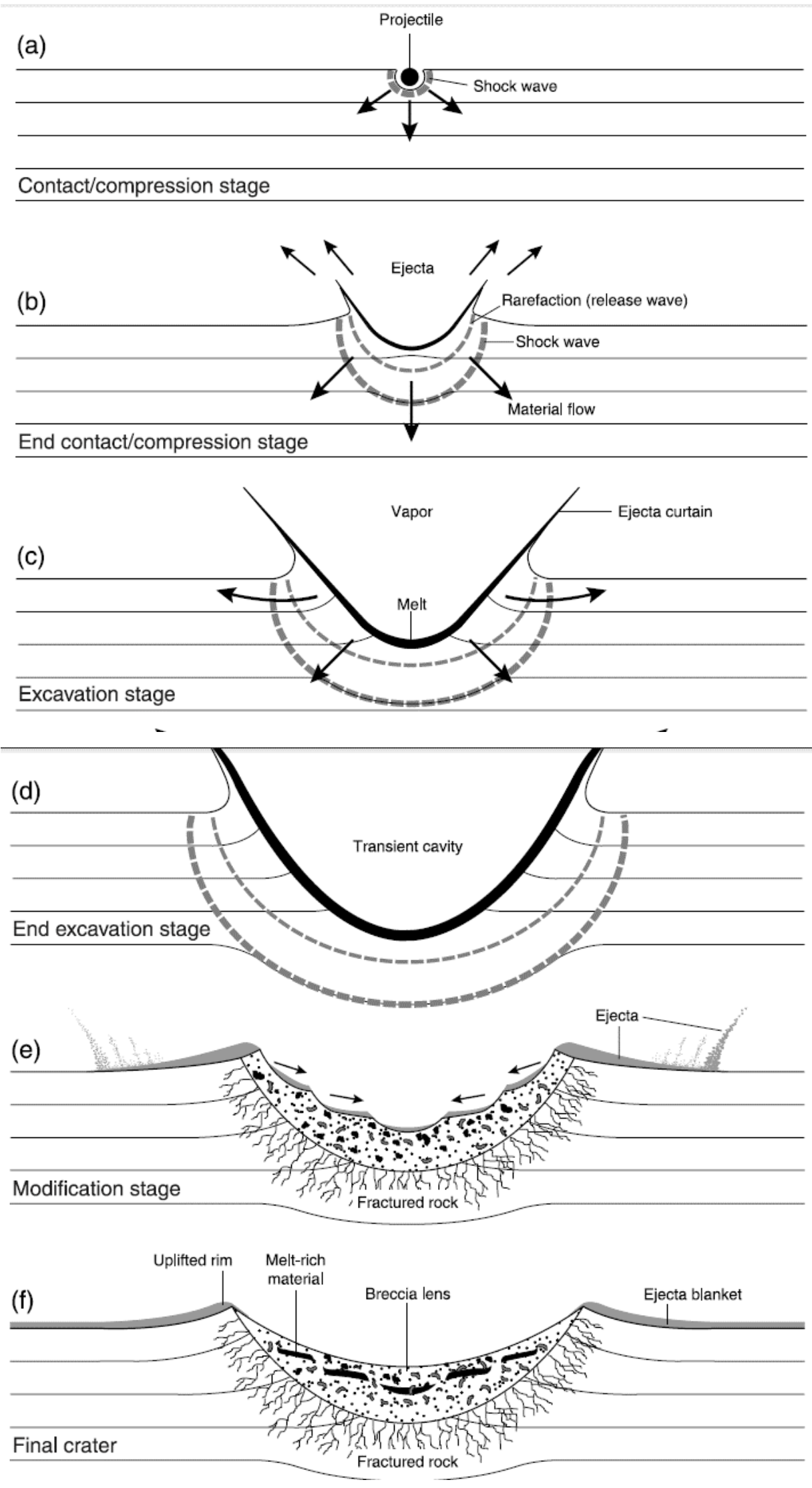

Figura 3 - Representação da formação de uma estrutura de impacto simples. Estágio de contato e compressão (a), estágio de escavação (bd), estágio de modificação (e-f). Fonte: French, 1998. 
O estágio de escavação sucede o de contato e compressão e se caracteriza pela ocorrência de dois eventos principais: a expansão das ondas de choque e o fluxo de escavação. As ondas de choque propagam-se igualmente para todos os lados, formando um padrão hemisférico, e se enfraquecem à medida que se expandem e abrangem maior volume de material. Elas não são responsáveis pela translocação de materiais dentro da cratera, uma vez que apenas provocam a fragmentação dos constituintes rochosos. A translocação é realizada pelo fluxo de escavação, que consiste na propagação subsônica do alívio de pressão inicialmente dada pelo choque, e responsabiliza-se pela efetiva abertura da cratera (MELOSH, 1989, p. 46).

O fluxo de escavação implica na ausência de participação direta do bólido na abertura da cratera, permitindo que ela tenha dimensões muito maiores que o corpo impactante, até dez vezes seu tamanho. O fluxo de escavação propaga-se a velocidades inferiores às das ondas de choque e também decai com a distância, até cessar. $O$ tempo de atuação do fluxo e a quantidade de material remobilizado são diretamente proporcionais à quantidade de energia liberada no impacto. Ao final desse estágio obtém-se uma cratera temporária (transient crater), em forma de parabolóide de revolução ${ }^{1}$, que possui relação profundidade/diâmetro de 1/4 a 1/3 e apresenta paredes internas muito íngremes (MELOSH, op cit, p. 129; GRIEVE e PESONEN, 1992).

Nos estágios de contato e compressão e de escavação, fragmentos rochosos são lançados do local do impacto e a maioria retorna à superfície do planeta, formando uma pilha de detritos designados pelo termo "ejecta". Parte desse material fica retido na crista da cratera, contribuindo com $50 \%$ de sua altura. O restante forma uma cobertura contínua de ejecta no exterior da cratera, até cerca de um raio de distância a partir de sua borda, tornada descontínua e cada vez mais delgada a partir deste limite. Compõe-se de clastos com diâmetros que variam de alguns $\mu \mathrm{m}$ a alguns $\mathrm{km}$, com granulometria também decrescente com a distância, sem haver predomínio claro de alguma faixa granulométrica (MELOSH, op cit).

\footnotetext{
1 Um parabolóide de revolução é uma superfície obtida a partir da rotação de uma parábola ao redor de seu eixo. O volume do parabolóide de revolução é obtido a partir da relação $V=\frac{\pi R^{2} h}{2}$, onde $\mathrm{R}=$ raio da base do parabolóide e $\mathrm{h}=$ altura do parabolóide.
} 

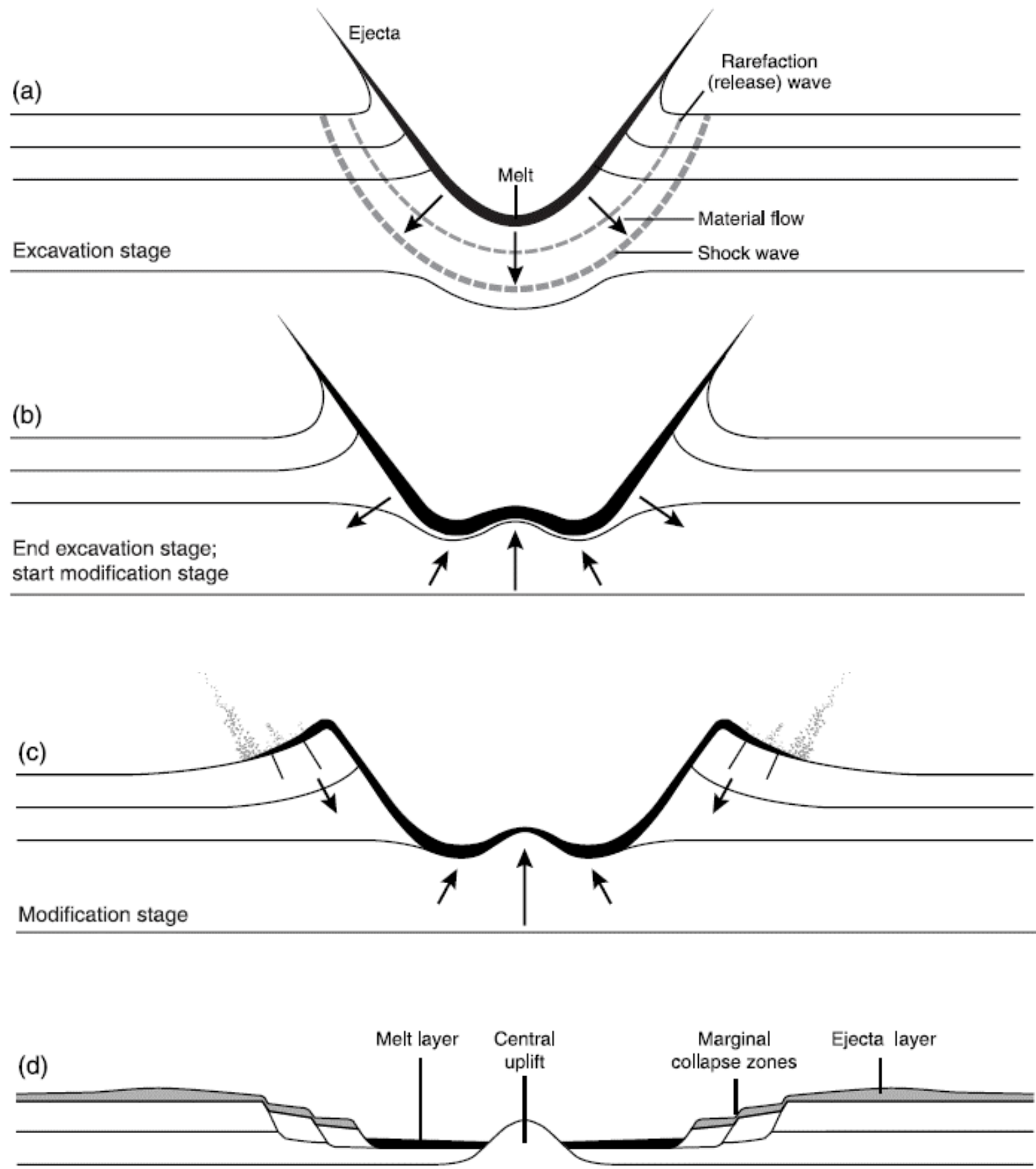

Figura 4 - Representação da formação de uma estrutura de impacto complexa, com colapso gravitacional das bordas, formação de um pico central e de terraços escalonados de colapso. Fonte: French, 1998. 
A cratera transitória formada no estágio de escavação é instável, devido à alta declividade e à altura da crista e logo ocorre o colapso gravitacional de suas paredes, com o retorno de materiais, que preenchem parcialmente a cavidade, no estágio de modificação. A intensidade do colapso gravitacional é proporcional ao tamanho da cratera formada. Em crateras menores, há o simples preenchimento da cavidade central por detritos da crista. Já nas maiores, o colapso é mais complexo, com ocorrência de terraceamento e falhamentos do embasamento na sua borda (Figura 4). Essas diferenças dão origem aos dois tipos morfológicos básicos de crateras de impacto: simples e complexas, tratadas mais adiante. O estágio de modificação termina quando se encerra o colapso gravitacional dos materiais lançados do sítio do impacto e se iniciam processos geomorfológicos mais "convencionais" de erosão e sedimentação (MELOSH, 1989, p. 126; DRESSLER e REIMOLD, 2001).

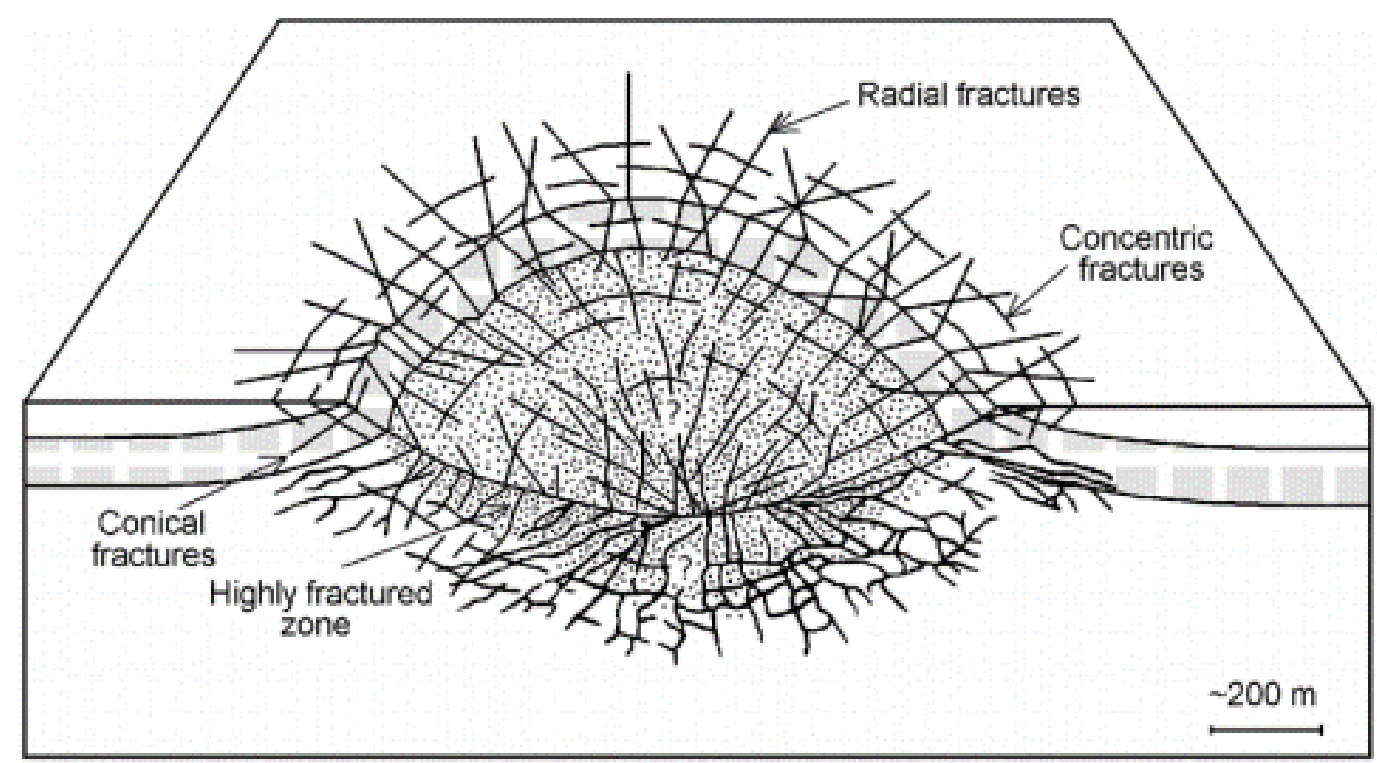

Figura 5 - llustração esquemática exibindo as fraturas na borda da cratera do Meteoro, Arizona. Fonte: Kumar e Kring, 2008.

Durante o processo de craterização, é comum a formação de fraturas radiais e concêntricas no entorno da cratera de impacto. Jones (1977) produziu crateras experimentais no alúvio e descreveu fraturas que se formaram nas camadas superficiais do pacote aluvial. Algumas foram preenchidas por areia, formando estruturas semelhantes a diques, mas não se estenderam além da borda da cratera. 
Em feições maiores, elas também podem aparecer. As fraturas formadas não se estenderam para além da borda da cratera.

Kumar e Kring (2008) descrevem fraturas radiais e concêntricas formadas na borda da cratera do Meteoro, no Arizona, que se estendem para além da borda da cratera a até $1 / 3$ de seu raio (Figura 5). Henkel et al. (2010) identificaram fraturas radiais e concêntricas no entorno da estrutura Tvaren, na Finlândia, a distâncias semelhantes da cratera de impacto, sugerindo haver proporcionalidade entre 0 tamanho da cratera e o tamanho da zona de falhas radiais e concêntricas.

\subsubsection{Impactos oblíquos e craterização}

A incidência de bólidos nas superfícies planetárias raramente ocorre na vertical; o ângulo mais provável para projéteis de incidência aleatória é de $45^{\circ}$ em relação à superfície (MELOSH, 1989, p. 49). No entanto, a maioria das crateras de impacto exibe alta circularidade. Estudos experimentais conduzidos por Gault e Wedekind (1978) mostram que a circularidade é mantida em ângulos de impacto superiores a $30^{\circ} \mathrm{em}$ relação à superfície. Crateras formadas a partir de impactos de ângulos menores, nas mesmas condições, tendem a se alongar ligeiramente no eixo da trajetória do projétil e possuir menores dimensões, em função da menor eficiência na troca de energia entre o projétil e o alvo. Em impactos de ângulos inferiores a $10^{\circ}$ ocorre o ricocheteamento do projétil e a formação de crateras bastante alongadas.

A circularidade da maioria das crateras deve-se à analogia entre impacto e explosão proposta por Öpik (1916) apud Melosh (op cit, p. 5). Em impactos oblíquos, no estágio de contato e compressão, forma-se uma zona alongada de altíssimas pressões na direção da trajetória do projétil, que se expande mediante ondas de choque que se propagam à mesma velocidade para todas as direções. A zona alongada evolui para uma zona praticamente circular de altas pressões antes da formação da borda da cratera, que se constitui circularmente (MELOSH, 1989, p. 50).

No entanto, ocorrem modificações na morfologia da cratera resultante (Figura 6): a zona de maior profundidade da cratera desloca-se para o sentido de proveniência do bólido e os depósitos de materiais ejetados do local do impacto distribuem-se de maneira assimétrica. Em impactos verticais, todas as direções do entorno receberiam depósitos de ejecta de modo similar; em impactos oblíquos, por outro lado, o 
lançamento de ejecta, que ocorre nas fases iniciais da craterização, tende a assumir direções preferenciais. Em ângulos inferiores a $60^{\circ}$, os depósitos de ejecta concentram-se preferencialmente no sentido oposto ao da incidência do bólido. Ângulos inferiores a $45^{\circ}$ são associados à formação de uma "zona proibida" no sentido do ingresso do bólido e ângulos inferiores a 20 levam ao desenvolvimento de uma nova "zona proibida" no sentido oposto ao do ingresso do bólido, atravessada por raias brilhantes emanadas da cratera, que tende a se tornar alongada. Depósitos de ejecta são bilateralmente simétricas, formando um padrão "em borboleta", permitindo, se presentes, a determinação do ângulo do impacto (MELOSH, 1989, p. 101).

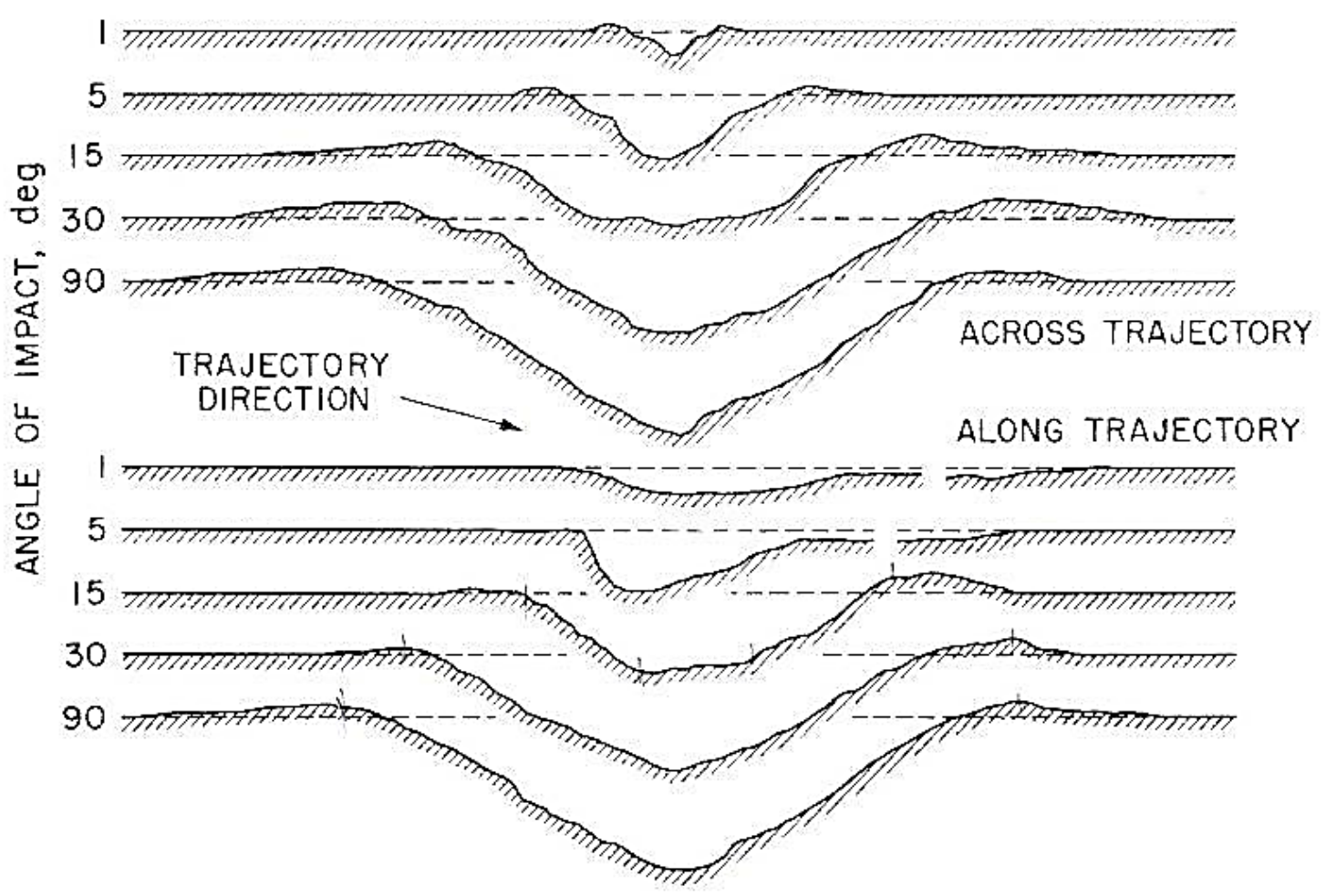

Figura 6 - llustração esquemática mostrando resultado de experimentos de impactos oblíquos. Geometria de crateras formadas em cinzas vulcânicas por impactos oblíquos de esferas de pyrex a velocidade de aproximadamente $6,4 \mathrm{~km} / \mathrm{s}$. Fonte: Gault e Wedekind, 1978.

A análise da morfologia de uma cratera de impacto, por si só, não oferece diagnóstico do sentido do bólido, pois assimetrias morfológicas também podem ser produzidas por processos de degradação da cratera de impacto ou a respostas contrastantes das unidades geológicas as pressões de choque (SCHULTZ e 
ANDERSON, 1996). Além disso, os depósitos de ejecta desaparecem rapidamente com a evolução geomorfológica das crateras (DENCE, 1972), sendo mais seguro avaliar o sentido da proveniência do bólido a partir da identificação do deslocamento da zona de maior profundidade em relação ao centro da estrutura.

Schultz e Anderson (1996) elencam como evidências da formação da cratera de Manson (EUA) por impacto oblíquo de um bólido proveniente de sudeste com ângulo de 20 a $30^{\circ}$ a partir da horizontal: o soerguimento máximo do pico central, correspondente à penetração máxima do bólido, deslocado para sudeste do centro geométrico da cratera; o pico central rompido paralelamente em relação à trajetória; o pico central de tamanho exagerado em relação ao tamanho total; cratera alongada na direção noroeste-sudeste; altura mínima da borda da cratera para noroeste; e profundidade de escavação mais rasa que o esperado.

\subsubsection{Diversidade morfológica das crateras de impacto}

Há dois tipos básicos de crateras de impacto, do ponto de vista morfológico: as simples e as complexas (GRIEVE e PESONEN, 1992). As primeiras exibem forma de "tigela", com uma depressão central e uma única crista anelar circundando-a; já as últimas possuem picos ou anéis centrais e blocos basculados concêntricos, com possibilidade de haver mútiplos anéis. A diferenciação entre elas ocorre no estágio de modificação e é função da escala do colapso gravitacional: quanto maior a estrutura, mais extensivo é o colapso (DRESSLER e REIMOLD, 2001).

O tipo de colapso sofrido pela cratera transitória é governado por algum parâmetro $k$, ainda desconhecido, que é excedido. Esse parâmetro $k$ é função da profundidade escavada, da densidade da rocha e da gravidade. Nota-se formação de morfologia complexa quando o bólido possui maior energia cinética ou quando a superfície atingida é constituída por rochas menos resistentes ao impacto ou em corpos planetários com maior gravidade (na Terra, crateras complexas formam-se a partir de diâmetros 6 vezes menores que na Lua) (MELOSH, 1977).

As crateras de impacto simples (Figura 7) possuem perfil aproximadamente parabólico, um único anel soerguido e cerca de $40 \%$ de seu volume preenchido por materiais fragmentados, expelidos e retornados durante o processo de impact cratering. Cerca de $1 / 4$ da altura do anel soerguido da cratera forma-se a partir 
soerguimento estrutural e $3 / 4$ a partir de material ejetado da zona central (MELOSH, 1989, p. 18). Segundo Grieve e Pesonen (1992), em crateras simples, cerca de $10 \%$ do material detrítico da lente de brechas mostra efeitos de metamorfismo de choque, como PDFs e cones de estilhaçamento, entre outros. Efeitos de choque nas rochas autóctones restringem-se ao fundo da cratera verdadeira, onde a pressão de choque é inferior a $25 \mathrm{GPa}$.

As crateras de impacto complexas (Figura 8), por sua vez, possuem uma depressão aproximadamente plana, menor razão profundidade-diâmetro e picos centrais. Por terem maior extensão horizontal (à superfície) e vertical (através das unidades litológicas), preservam-se por mais tempo (DENCE et al, 1977), daí sua maior participação na quantidade total de crateras de impacto conhecidas na Terra, a despeito da maior frequência de impactos menores (TREFIL e RAUP, 1990). Nas maiores crateras complexas, as bordas sofrem colapso ao longo de falhas concêntricas recém-formadas, dando lugar a um ou mais anéis deprimidos, mencionados como hemi-grabens anelares e uma série de terraços ao longo das margens externas da estrutura formada.

A transição entre as duas morfologias se dá entre 2 e $4 \mathrm{~km}$ na Terra, abrupta em litologias sedimentares e mais gradual em litologias cristalinas, visto que nas últimas a resistência à produção de crateras complexas é maior (DENCE, 1972).

Baldwin (1963) sugere que o pico central das crateras complexas deve-se ao fato de que, em vez de deformar plasticamente, a rocha torna-se muito compressível e rebate elasticamente. Tal ideia é rediscutida por Melosh (op cit, p. 141-54), comparando duas hipóteses: na primeira, o colapso no estágio de modificação seria mais intenso em crateras maiores que nas menores, com a formação do pico central em decorrência do transporte de material detrítico das periferias ao centro por movimento de massa; já na segunda hipótese, o pico central das crateras complexas seria decorrente de soerguimento elástico do material do centro da cratera. 


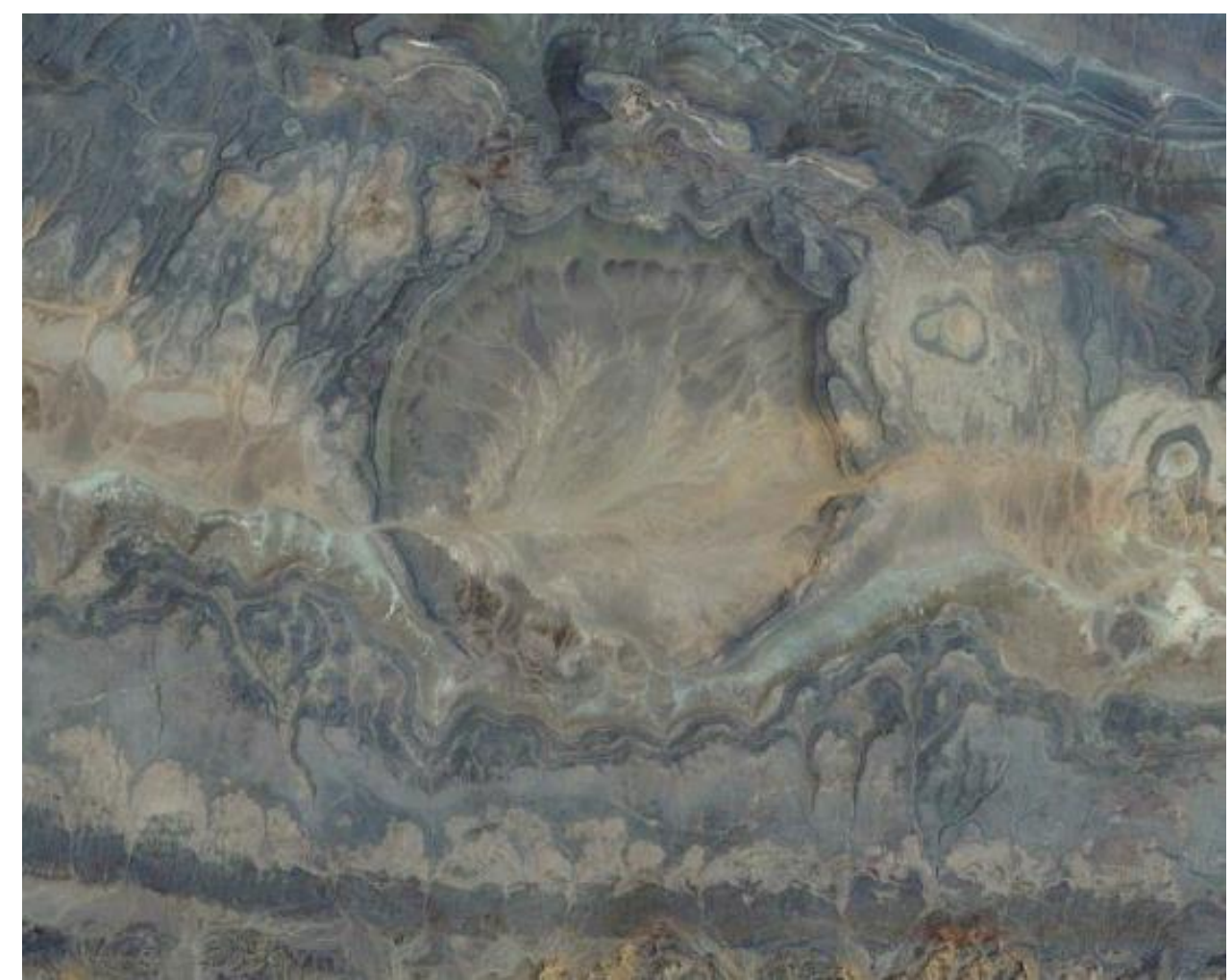

Figura 7 - Cratera de Ouarkziz, Argélia, exemplo de morfologia simples. Escala aproximada: 1:67.000. Obtida de: Google Earth, 2012, Fonte: CNES/Spot, 2008.

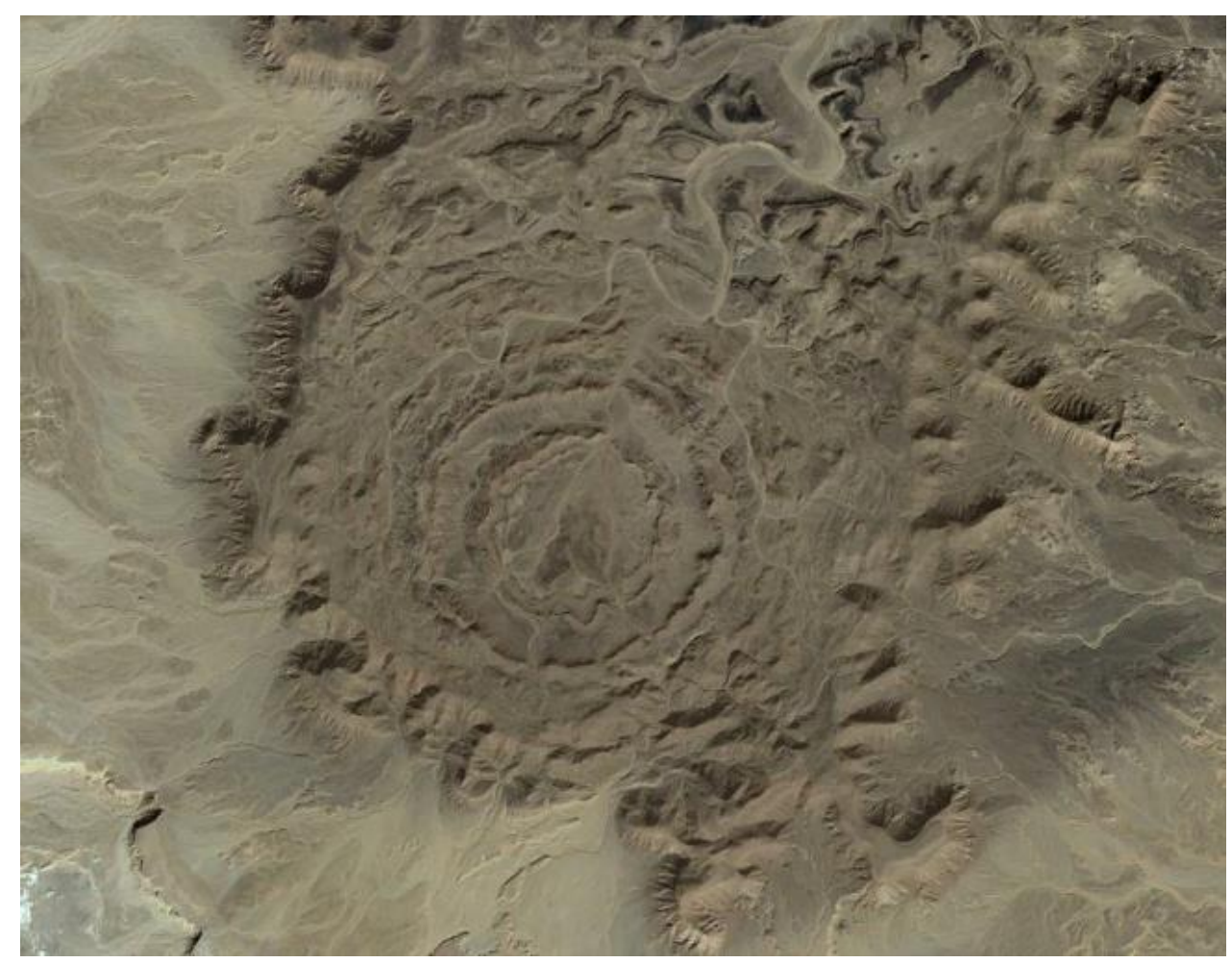

Figura 8 - Cratera de Tin Bider, Argélia, exemplo de morfologia complexa. Escala aproximada: 1:67.000. Obtido de: Google Earth, 2012. Fonte: CNES/Spot, 2008. 
Para Melosh (1989, p. 141), os dois mecanismos são complementares na formação de picos centrais em crateras complexas. Já o anel soerguido da cratera complexa, ao colapsar, pode dar lugar a uma depressão anelar, a uma zona de distúrbio litológico sem ressalto topográfico ou a um pequeno soerguimento anelar (DENCE, 1972).

As crateras complexas apresentam uma gradação de morfologias, em função do diâmetro, em ordem crescente: crateras de pico central, bacias de pico central com anel circundante, bacias de pico central anelar com apenas um anel circundante, bacias multi-anelares com vários anéis circundantes (GRIEVE e PESONEN, 1992).

Crateras complexas podem apresentar unidades ígneas consideráveis, por vezes confundidas com plútons ou com remanescentes vulcânicos. No entanto, os minerais das rochas ígneas formadas por impacto se formaram por fusão total das rochas superficiais, ao contrário das rochas vulcânicas e plutônicas, formadas a partir de magma derivado de fusão parcial do manto superior e da crosta inferior, facilitando sua diferenciação (FRENCH, 1998).

\subsubsection{Impactos e estruturas concêntricas derivadas}

Diversas crateras de impacto exibem morfologia multi-anelar, com vales e cristas concêntricos e uma depressão central circular. Melosh (op cit, p. 131), considerando as indefinições existentes a respeito da origem dessas estruturas, conclui que para este problema há aproximadamente tantas interpretações quanto investigadores. Levantam-se, a seguir, algumas dessas possíveis interpretações quanto à origem de estruturas de impacto com as referidas características.

\subsubsection{Estratificação do alvo}

Dada a prevalência das camadas sedimentares nas superfícies das terras emersas, conclui-se que, com certa frequência, impactos meteoríticos ocorrem em áreas nas quais as rochas exibem estratificação. Nessas condições, a cratera de impacto formada deverá sofrer, em sua morfologia, influência das propriedades físicas do acamamento. Melosh (op cit, p. 82) discute os aspectos morfológicos de crateras de impacto formadas em terrenos nos quais camadas menos resistentes se 
sobrepõem a camadas mais resistentes, condições que podem ser encontradas, por exemplo, em camadas de arenitos sobrepostas a basaltos ou em areias e argilas sobrepostas ao embasamento cristalino.

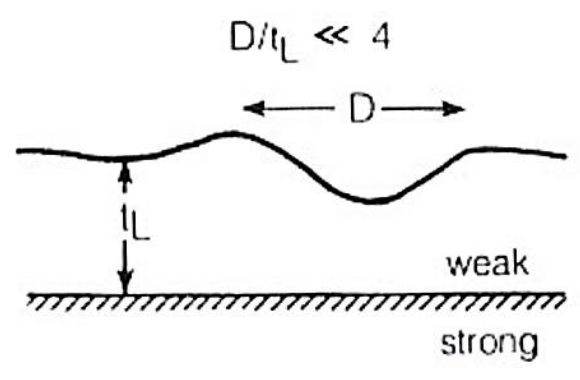

Normal morphology

$D: L=8 \cdot 10$

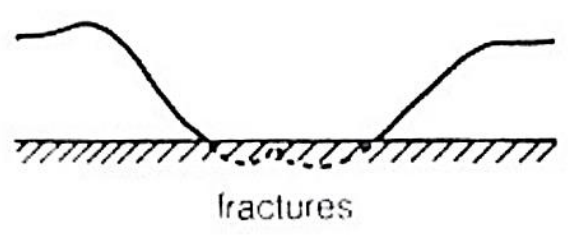

Flat floor

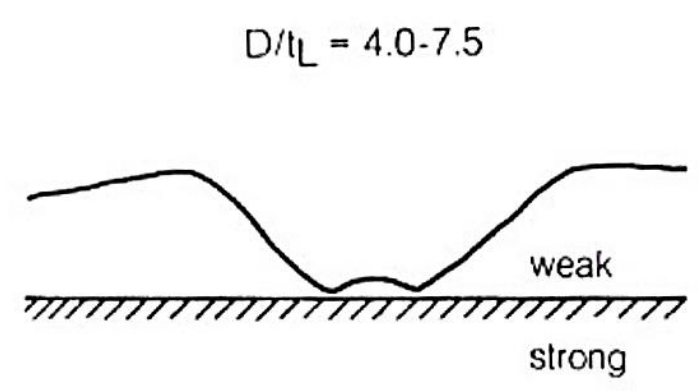

Central mound

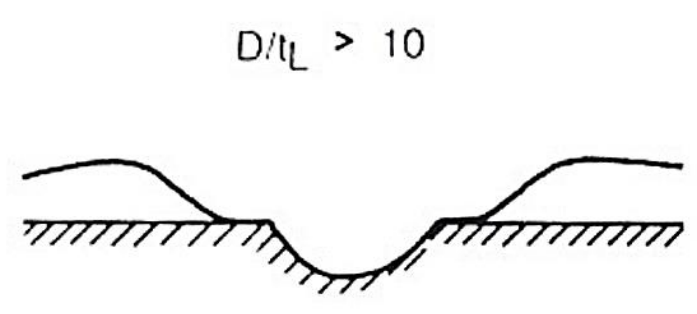

Concentric crater

Figura 9 - A morfologia de crateras formadas em uma camada fraca sobrejacente a uma camada mais resistente. Dependendo da razão entre o diâmetro da cratera $\mathrm{D}$ e a espessura da camada fraca $\mathrm{t}_{\mathrm{L}}$, a cratera pode adquirir uma morfologia normal de tigela, possuir uma saliência central, um fundo plano ou bancadas em suas paredes internas. Fonte: Melosh, 1989, p. 82.

Citando W. Quaide e V. Oberbeck, que realizaram estudos experimentais no final dos anos 1960, o autor aponta que a morfologia da cratera final depende da razão entre o diâmetro da crista da cratera $D$ e a espessura da camada de menor resistência $t_{L}$. Conforme se observa na Figura 9 , crateras nas quais a relação $D / t_{L}$ é menor que 4 adquirem forma normal de tigela (em crateras simples), sem influência da estratificação. Quando $D / t_{L}$ é maior que 4 e menor que 7,5, um pequeno monte se forma no centro da cratera, pois o fluxo de escavação é barrado pela camada resistente. Se $D / t_{L}$ situa-se entre 7,5 e 10 , o fluxo de escavação é suficientemente 
forte para alcançar de maneira mais definitiva a camada resistente, provocando seu fraturamento e a formação de uma superfície aplainada no centro da estrutura. Por fim, para $D / t_{L}$ maior que 10 , uma pequena cratera também se forma na camada resistente, levando a formação de duas crateras concêntricas separadas por um terraço, ou bancada. À medida que o diâmetro da cratera cresce para além dessa transição final, o terraço ocorre a elevações progressivamente maiores na parede interna da crista, tornando-se menos evidente.

A estrutura Tin Bider, na Argélia, possui $6 \mathrm{~km}$ de diâmetro e exibe uma série de três cristas anelares. Ela foi produzida em formações de argilas e calcários do Cretáceo Inferior ao Superior e sua morfologia pode ser atribuída à diferença de resistência das camadas sedimentares às pressões de choque. Arenitos do Cretáceo Inferior são expostos na parte central da estrutura. A estratigrafia das cristas calcárias é muito complexa e os estratos são intensamente dobrados (KOEBERL, 1994).

\subsubsection{Pico anelar em crateras complexas}

Outro mecanismo que reconhecidamente produz crateras com aneis concêntricos é a modificação do pico central da cratera complexa em uma feição denominada pico anelar (tradução de "peak-ring"), constituinte intermediário da gradação morfológica existente em crateras complexas de tamanho crescente, entre crateras de pico central e bacias multi-anelares (GRIEVE e PESONEN, 1992). Tratase de um anel contínuo ou semi-contínuo de picos, completamente separado das paredes das bordas da cratera, topograficamente mais baixa que as bordas (KOMATSU et al., 2006).

A feição se forma em crateras com diâmetro mínimo de $227 \mathrm{~km}$ na Lua, $116 \mathrm{~km}$ em Mercúrio, $56 \mathrm{~km}$ em Marte e $33 \mathrm{~km}$ em Vênus, devido à influência da gravidade no colapso de crateras complexas (BAKER et al., 2011). Na Terra, é possível haver formação dessa feição em crateras de no mínimo $25 \mathrm{~km}$ de diâmetro (MORGAN et al., 2000); as crateras Gosses Bluff, na Austrália (DIETZ, 1967), e Chicxulub, no México (ALVAREZ et al., 1995), constituem notáveis exemplos. A relação entre o diâmetro do pico anelar e o diâmetro da borda da cratera é universal em planetas terrestres (Gráfico 1), de tal modo que o primeiro corresponde a $50 \%$ do último (MELOSH, 1989). 


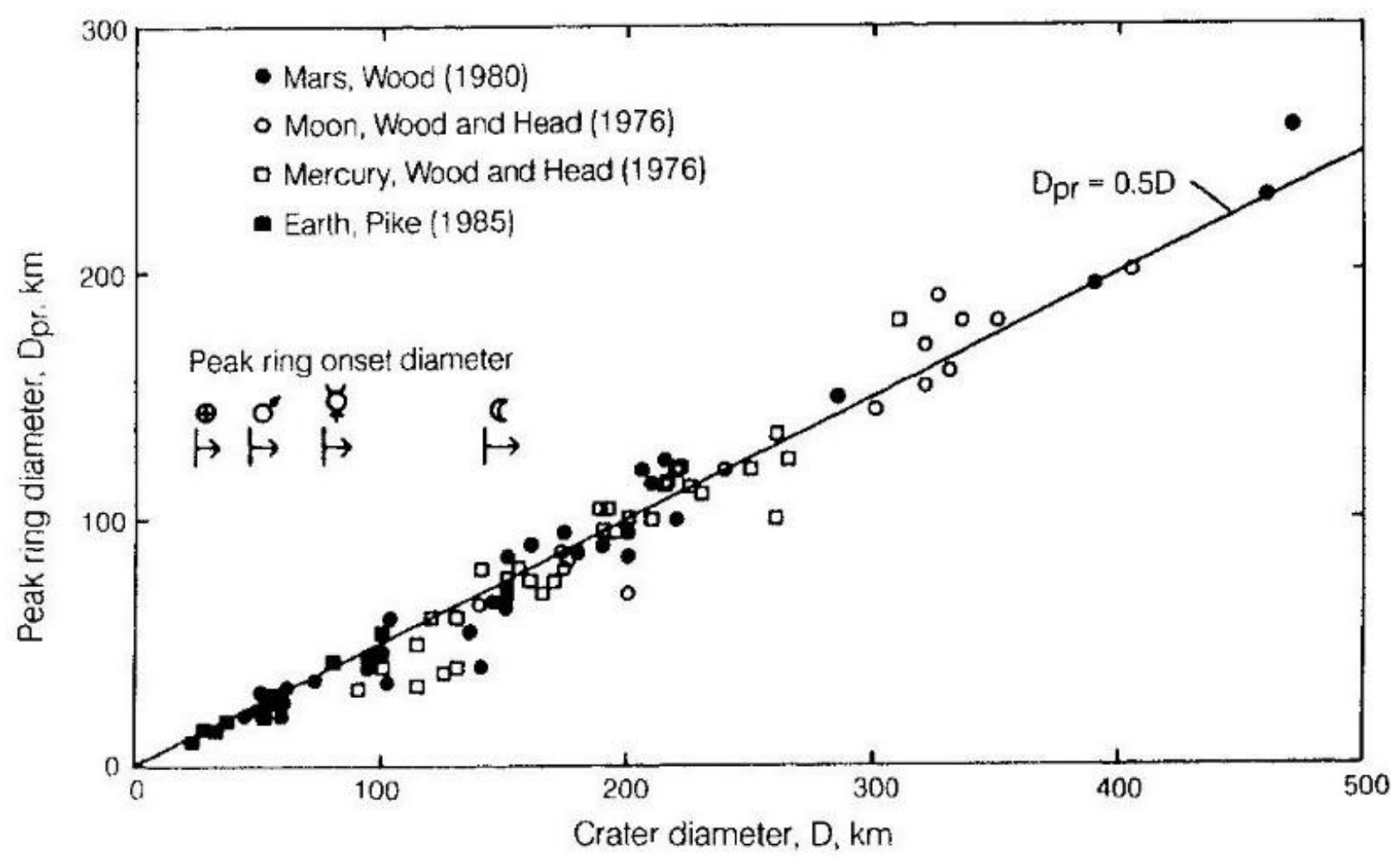

Gráfico 1 - A relação entre o diâmetro do pico anelar (peak-ring) e a borda da cratera é constante nos planetas terrestres e o surgimento da feição é dependente da gravidade: quanto maior a gravidade, menor o diâmetro da cratera necessário para sua formação. Extraído de Melosh, 1989, p. 143.

Há duas explicações concorrentes para a origem do pico anelar: colapso de pico central excessivamente soerguido, descrito pelo modelo hidrodinâmico (MELOSH, 1989, p. 143); modificação e colapso de uma cavidade preenchida por material fundido, descrita pelo modelo da "Cavidade Fundida Aninhada" (tradução de "nested melt-cavity"), conforme Baker et al. (2011).

Para Melosh (op cit, p. 143), o pico anelar se forma quando o pico central colapsa após um soerguimento inicial. Em seu modelo hidrodinâmico, o movimento dos detritos rochosos no interior da cratera deve ser semelhante ao de um fluido, envolvendo rápido soerguimento de um pico central, análogo ao jato central que se forma quando uma cavidade em água colapsa. Quando o pico central colapsa, um anel colinoso envolvendo seu antigo sítio se ergue, análogo à primeira onda que se desenvolve no entorno de uma gota que cai em um lago. A maior diferença entre o fluxo em uma cratera e no exemplo da gota na superfície de água é que na cratera o 
fluxo é "congelado", ou interrompido, em algum estágio intermediário, dependente do tamanho da cratera, logo após sua formação (Figura 10).
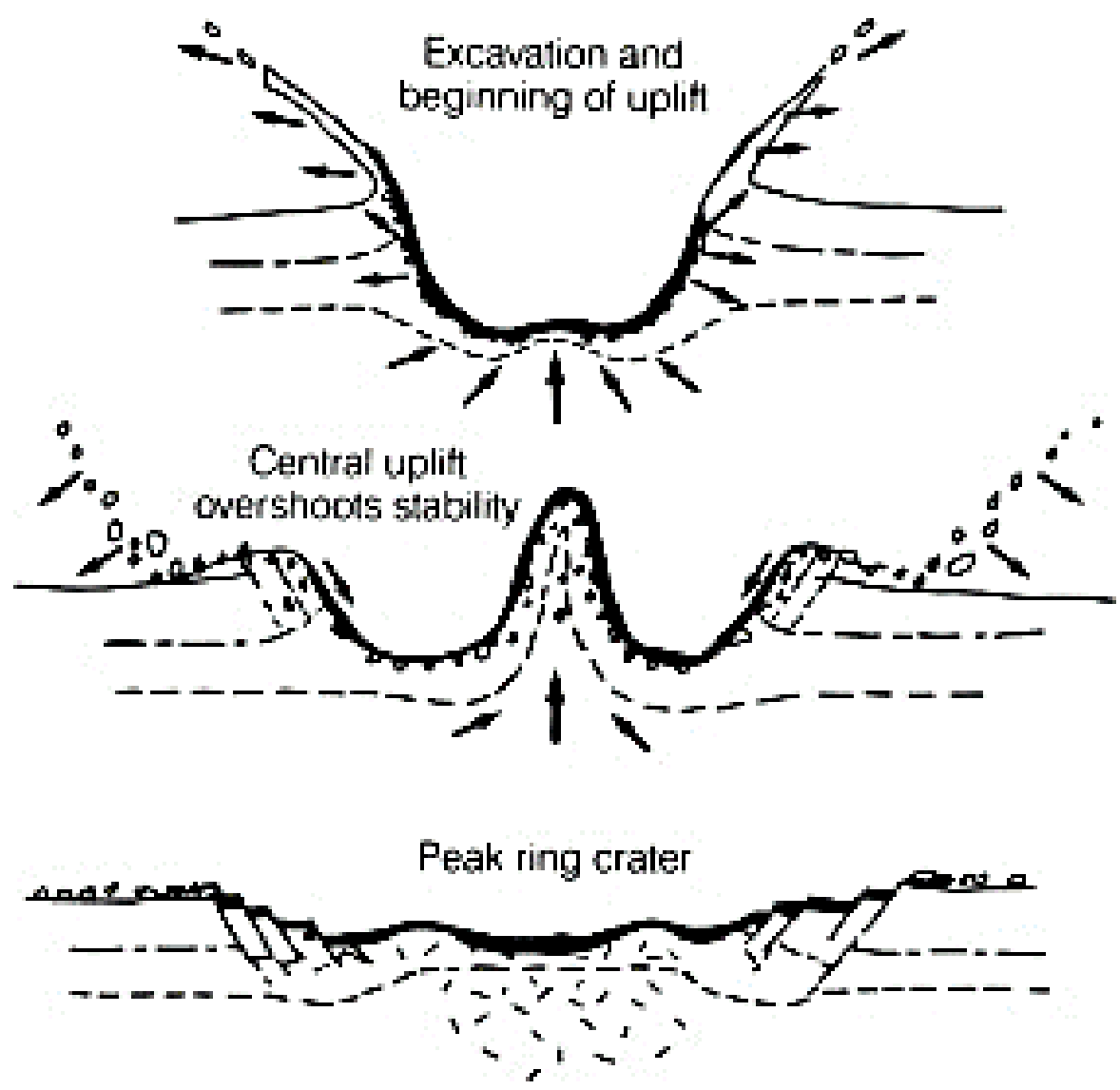

Figura 10 - llustração esquemática da formação de pico anelar (peak-ring) por colapso hidrodinâmico de um pico central excessivamente soerguido. $O$ soerguimento da cratera se inicia antes mesmo da borda estar completamente formada. À medida que o fundo da cratera sofre soerguimento, o colapso da borda gera um conjunto de terraços que envolvem a cratera. Em crateras menores, o soerguimento central "congela" para virar um pico central. Em crateras maiores, o pico central colapsa e cria um pico anelar antes de o movimento cessar. Fonte: Melosh, 1989, p. 142.

Já Baker et al. (2011) criticam a aplicação do modelo hidrodinâmico à formação do pico anelar, uma vez que ele não produz predições a respeito da proporcionalidade entre o diâmetro do pico anelar e o da cratera, que é constante. Conforme o modelo da Cavidade Fundida Aninhada, impactos de grandes proporções produziriam fusão de grande quantidade de rochas do embasamento. Assim, aneis seriam produzidos a 
partir do movimento do material fundido dentro da zona escavada, levando à supressão de estruturas centrais de soerguimento. Quando aproximadamente 3/4 da cavidade transitória é preenchida de material fundido, torna-se impraticável a formação de uma estrutura de soerguimento central e um pico anelar emerge como morfologia dominante.

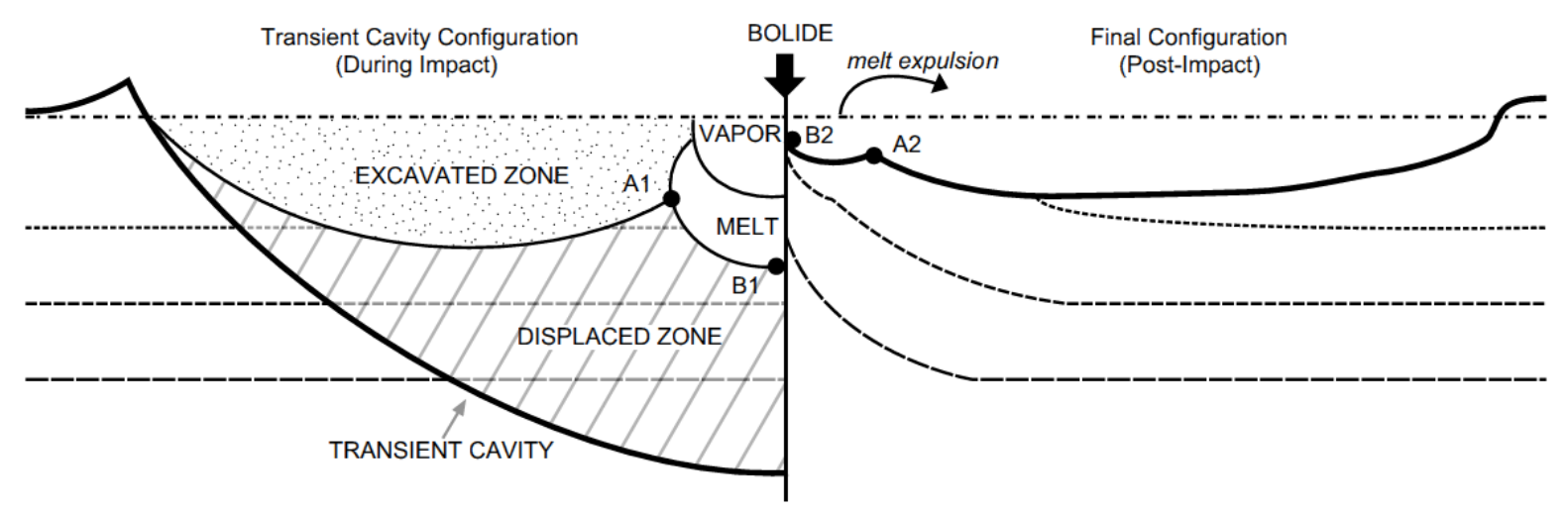

Figura 11 - Ilustração esquemática da formação de pico central (central peak) e pico anelar (peak-ring) e do crescimento não-linear do volume de material fundido de impacto (impact melt) em relação ao crescimento do volume da cratera, conforme o modelo da Cavidade Fundida Aninhada (nested melt-cavity). Nesse cenário, se um pico central está presente, tal feição é derivada da profundidade máxima da fusão sob o ponto do impacto (mostrado pelo soerguimento de B1 para B2 para formar um pico central). Picos anelares se originam de localizações exteriores à zona central de fusão (mostrado pelo soerguimento menor de A1 para A2). Para crateras de pico anelar, a formação de um pico central específico é inibida pelo crescimento da cavidade de material fundido. Fonte: Schon et al., 2011.

\subsubsection{Ejecta fluidificada}

Outro processo que leva à formação de feições concêntricas em crateras de impacto é a fluidificação de material que compõe o ejecta. O processo é documentado nas crateras de Marte e da Terra, sendo comum naquelas de diâmetros entre 5 e 15 $\mathrm{km}$ nas primeiras e em quaisquer diâmetros nas últimas. A presença de água subterrânea a cerca de $1 \mathrm{~km}$ de profundidade em Marte e em níveis variáveis na Terra explicaria esse contraste (MELOSH, 1989, p. 95-100). 
Nas crateras assim formadas, forma-se uma feição designada por "rampart", que consiste em uma crista concêntrica baixa, formada na extremidade da cobertura de ejecta na ocasião da interrupção do fluxo de seus constituintes devido à fricção provocada pelo aumento da área varrida (Figura 12). O rampart dista a cerca de um raio da borda da cratera e possui morfologia bastante irregular. A morfologia resultante deve-se aos obstáculos oferecidos pela superfície pré-impacto à movimentação do ejecta fluidificado (KOMATSU et al., 2006).

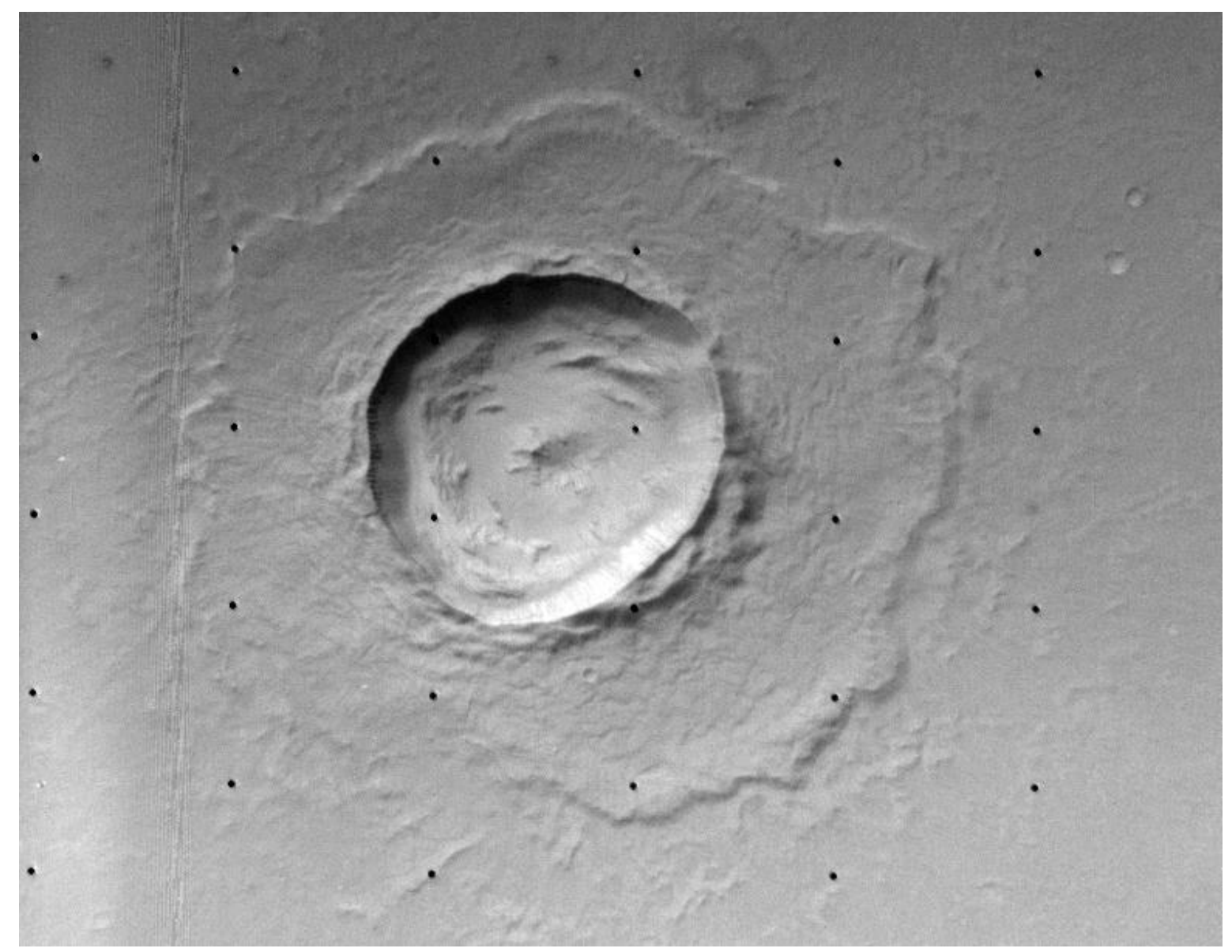

Figura 12 - Cratera de 9 km de diâmetro na Planitia Chryse, em Marte, com "rampart" produzido por fluidificação de ejecta. A cobertura de ejecta termina em um pequeno escarpamento com a vertente mais íngreme voltada para a superfície externa. Fonte: <http://cmex.ihmc.us/voviews/Craters/ Rampart.htm>. Acesso em 09 abr 2013.

Como na Terra há abundância de água na crosta e na atmosfera, pode-se assumir que muitas crateras de impacto se originaram com uma estrutura de ejecta fluidificada (KOMATSU et al., op cit). As águas subterrâneas ou zonas de permafrost 
podem se localizar bem próximas da superfície, dependendo das condições subsuperficiais dadas, levando à fluidificação do ejecta, que se movimenta de maneira semelhante a uma corrida de lama (mudflow) ou de detritos (debris flow) na sequência do impacto.

O fato de os depósitos de ejecta constituem a primeira unidade da estrutura de impacto a ser removida pela erosão pós-impacto (DENCE, 1972) faz com que essa feição seja raramente encontrada em crateras de impacto terrestres. Menciona-se como exemplo a cratera Tsenker (Figura 13), na Mongólia (KOMATSU et al., 2006).

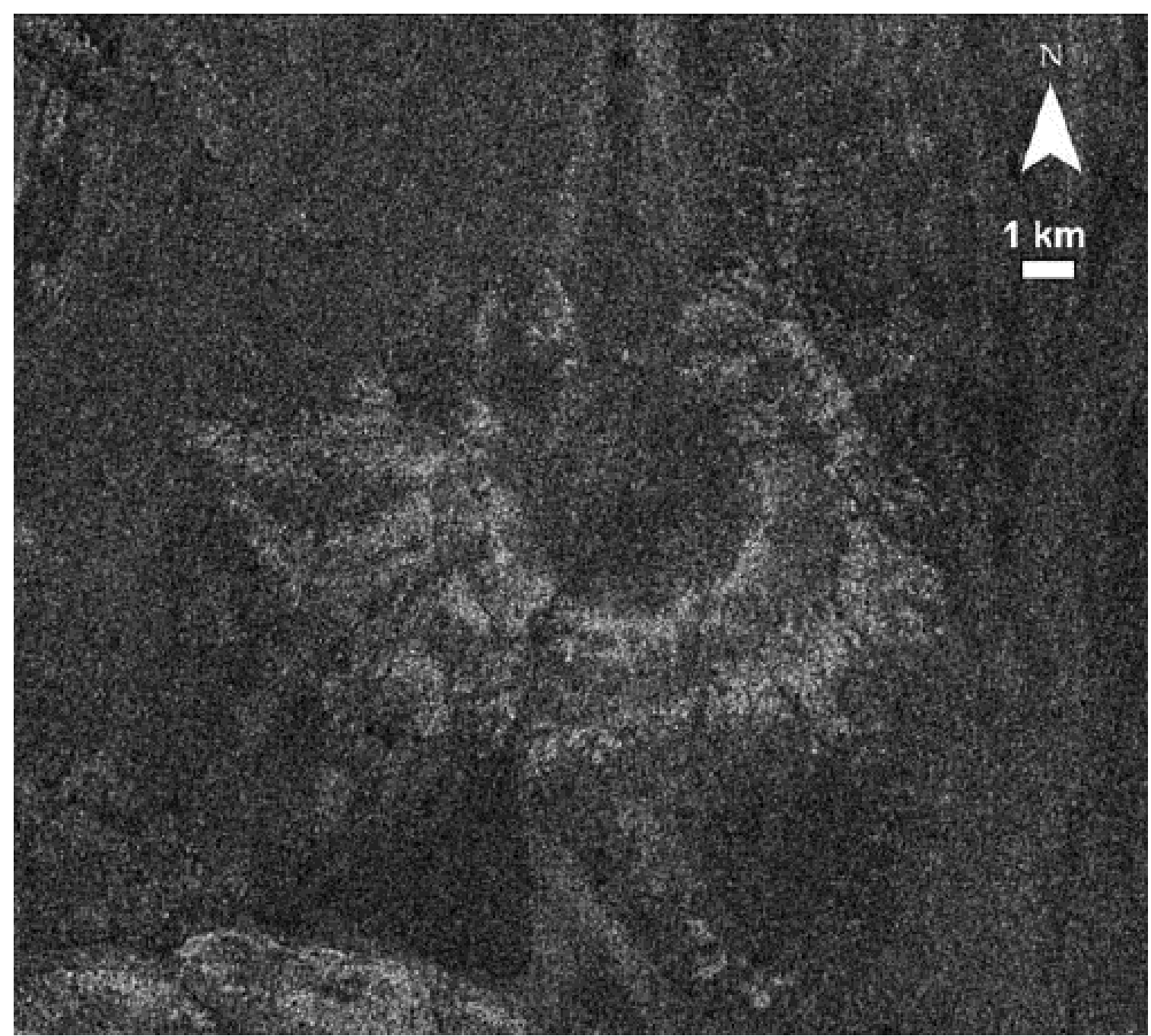

Figura 13 - Imagem de Radar, mostrando a estrutura Tsenkher, na Mongólia. Notar a existência de um segundo anel, envolvendo de maneira incompleta a cratera de impacto. Fonte: Komatsu et al., 2006. 
2.2.4.4. Fluidificação de finos

A fluidificação de sedimentos finamente granulados (argilas e siltes) devido à perda repentina de viscosidade em condições de alta tensão é um possível mecanismo para a formação de feições concêntricas em estruturas de impacto. Deste modo, haveria um comportamento bi-viscoso desses materiais conforme o modelo do fluido de Bingham (MELOSH, 1989, p. 148-50).

Jeong (2013) examina as características viscosas de argilas naturais sob diferentes condições de pressão utilizando o modelo de Bingham. O modelo compreende a existência de duas viscosidades: uma para baixas e outras para altas taxas de tensão. A baixas taxas de tensão, as argilas se comportam como um fluido de alta viscosidade, ao passo que a altas taxas de tensão, elas se comportam como um fluido de baixa viscosidade. As altas viscosidades sob baixas taxas de tensão são decorrentes da resistência da partícula em resposta às ligações microestruturais, as quais se rompem em altas tensões.

Impactos meteoríticos produziriam taxas de tensão suficientemente altas para que alvos ricos em argilas comportem-se como fluidos de Bingham. Submetidos a altas tensões, fluem com certa facilidade formando estruturas onduladas (MELOSH, op cit, p. 148). Essas estruturas podem se localizar tanto no interior quanto no exterior da cratera produzida. Após a redução da pressão de choque, o material volta a ter comportamento viscoso, interrompendo o movimento e preservando as ondulações produzidas.

A cratera Prairie Flat, de $86 \mathrm{~m}$ de diâmetro, foi produzida experimentalmente por detonação de 500 ton de TNT em siltes e argilas saturadas (PRICE e COSGROVE, 1990, p. 115). Como observado na Figura 14, a cratera é constituída de múltiplos aneis análogos aos observados nas maiores crateras de impacto. Neste exemplo, não é a intensidade da liberação de energia a responsável pela edificação dos aneis concêntricos, mas à propriedade dos materiais do alvo de se comportarem conforme o modelo de Bingham. 
(a)
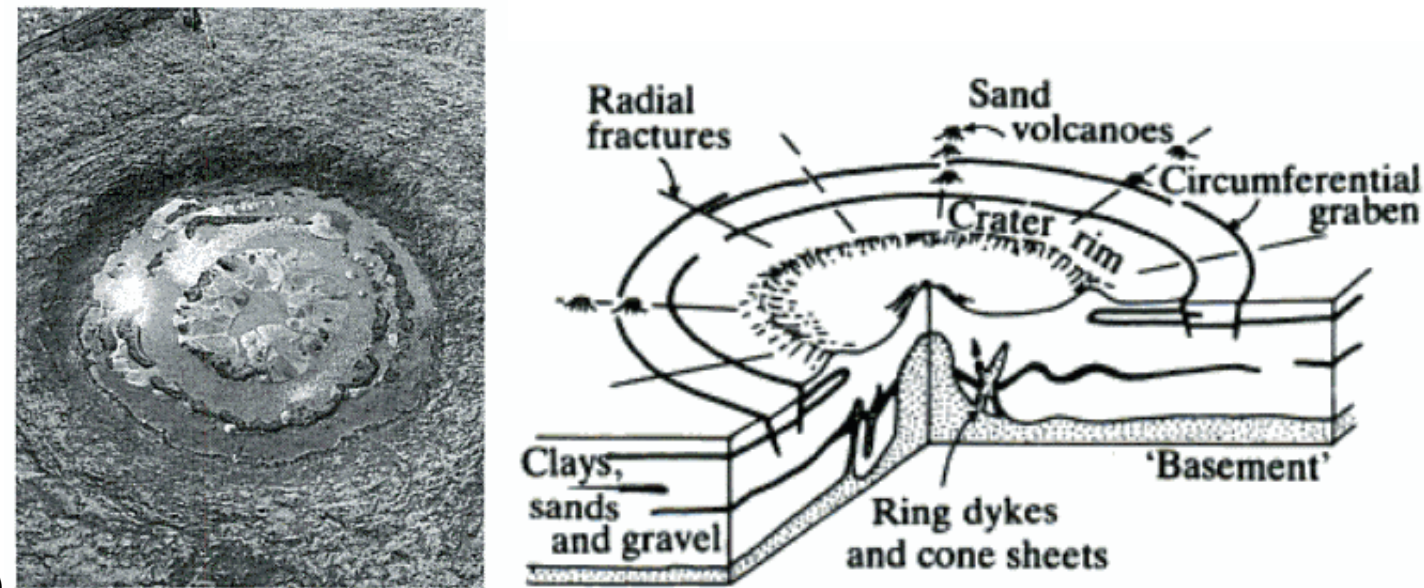

(b)

Figura 14 - Cratera Prairie Flat, produzida experimentalmente a partir da detonação de 500 ton de TNT. (a) fotografia aérea oblíqua da cratera. (b) síntese esquemática das estruturas geradas pela explosão experimental. Fonte: Price e Cosgrove, 1990, p. 115.

\subsection{DEGRADAÇÃO DE ESTRUTURAS DE IMPACTO E IMPLICAÇÕES GEOMORFOLÓGICAS}

Tricart (1965, p. 53) distingue formas vivas, que continuam a se desenvolver nas condições geomorfológicas atuais, das formas reliquiais, herdadas de uma situação anterior e modificadas conforme a dinâmica climática e tectônica. As crateras de impacto podem ser consideradas formas reliquiais do relevo, desenvolvidas no passado e em atual processo de modificação. Nesta seção, será discutida a evolução geomorfológica de estruturas de impacto, considerando que a morfologia atual da cratera depende de diversos fatores, como: condicionamento lito-estrutural, movimentação tectônica e condicionamento morfoclimático.

Segundo Ross (1990, p. 59), unidades geomorfológicas podem ser consideradas degradacionais ou agradacionais, conforme sua posição acima ou abaixo do nível de base local, respectivamente. Nas primeiras, há predominância da erosão sobre a sedimentação, ao passo que nas últimas é a sedimentação que prevalece. Deste modo, as superfícies geomorfológicas degradacionais tendem a diminuir em altitude e as superfícies agradacionais tendem a aumentar, à medida que os processos exógenos da formação do relevo prosseguem. 
As principais feições geológicas reconhecíveis em estruturas de impacto recém-formadas sustentam unidades geomorfológicas de ambos os tipos. Os aneis soerguidos e os picos centrais, se presentes, constituem unidades degradacionais, ao passo que a depressão central constitui unidade agradacional do relevo. Desconsiderando-se a ação de processos tectônicos, a tendência a longo prazo é o nivelamento da cratera, restando sua assinatura geofísica (baixos gravitacionais relacionados às áreas de rochas fraturadas com densidade reduzida em relação às rochas locais, além da formação de depressões onde se acumulam pacotes sedimentares) e a deformação das rochas por impacto (fraturamento, dobramento, metamorfismo de choque e fusão) para delineá-la.
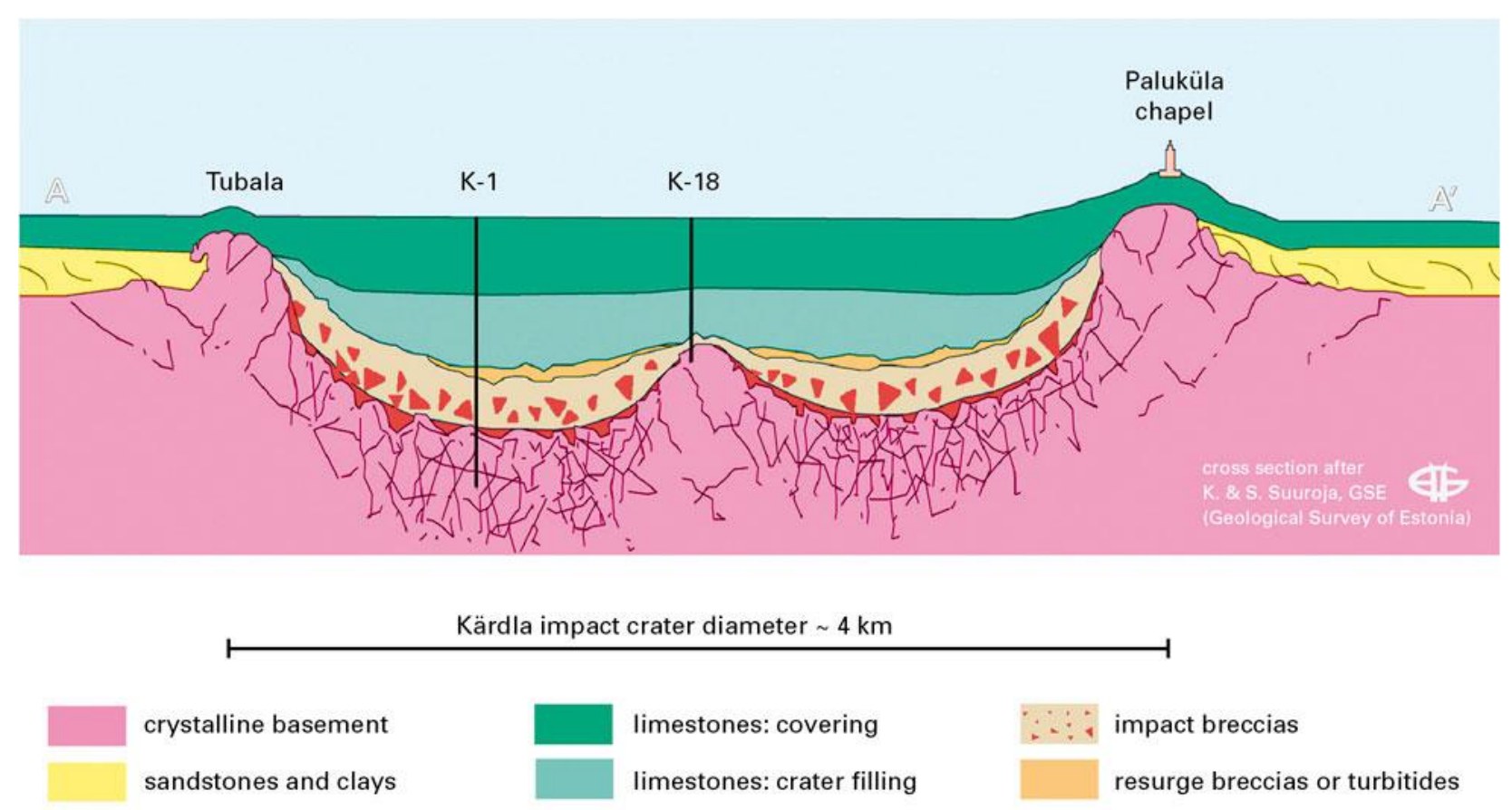

Figura 15 - Cratera Kärdla, na Finlândia. Preenchida por sedimentos, tornou-se sem expressão topográfica crateriforme. Um exemplo de estrutura de impacto sem cratera de impacto. Fonte: <http://www.egk.ee/about-gse/geological-treasures/kardla-crater/?lang=en>. Acesso em 10 abr 2013.

Crateras de impacto, quando niveladas por processos denudacionais, são denominadas "estruturas de impacto não expostas", sem a expressão topográfica crateriforme correspondente (PASSC, 2013). Exigindo estudos geológicos e geofísicos de detalhe, os registros delas são mais frequentes em regiões onde há mais 
investimentos nessas pesquisas, mencionando-se como exemplos as estruturas de: Kärdla (Figura 15), Iso-Naakkima e Mizarai, na Fenoscândia (HENKEL e PESONEN, 1992); Brent, Glasford e Newporte (GRIEVE e ROBERTSON, 1979) na América do Norte; Kelly West e Tookoonooka, na Austrália (HAINES, 2005).

Ao se avaliar o efeito do condicionamento lito-estrutural à morfologia atual de uma cratera, nota-se que estruturas de impacto são constituídas de unidades litológicas com diferentes resistências aos processos erosivos. Também são atravessadas por grande quantidade de fraturas, apresentando diversas linhas de fraqueza. Em uma estrutura complexa, por exemplo, o pico central contém materiais severamente chocados e metamorfizados e é frequentemente mais resistente à erosão que o restante da cratera. Em estruturas antigas erodidas, o pico central pode constituir o único remanescente da cratera (KOEBERL, 1994). A maior resistência do pico central leva à sua projeção em relação ao restante da estrutura em crateras terrestres como nas estruturas BP, na Líbia (Figura 16), e Gweni Fada, no Chade (BUCHNER e SCHMIEDER, 2007).

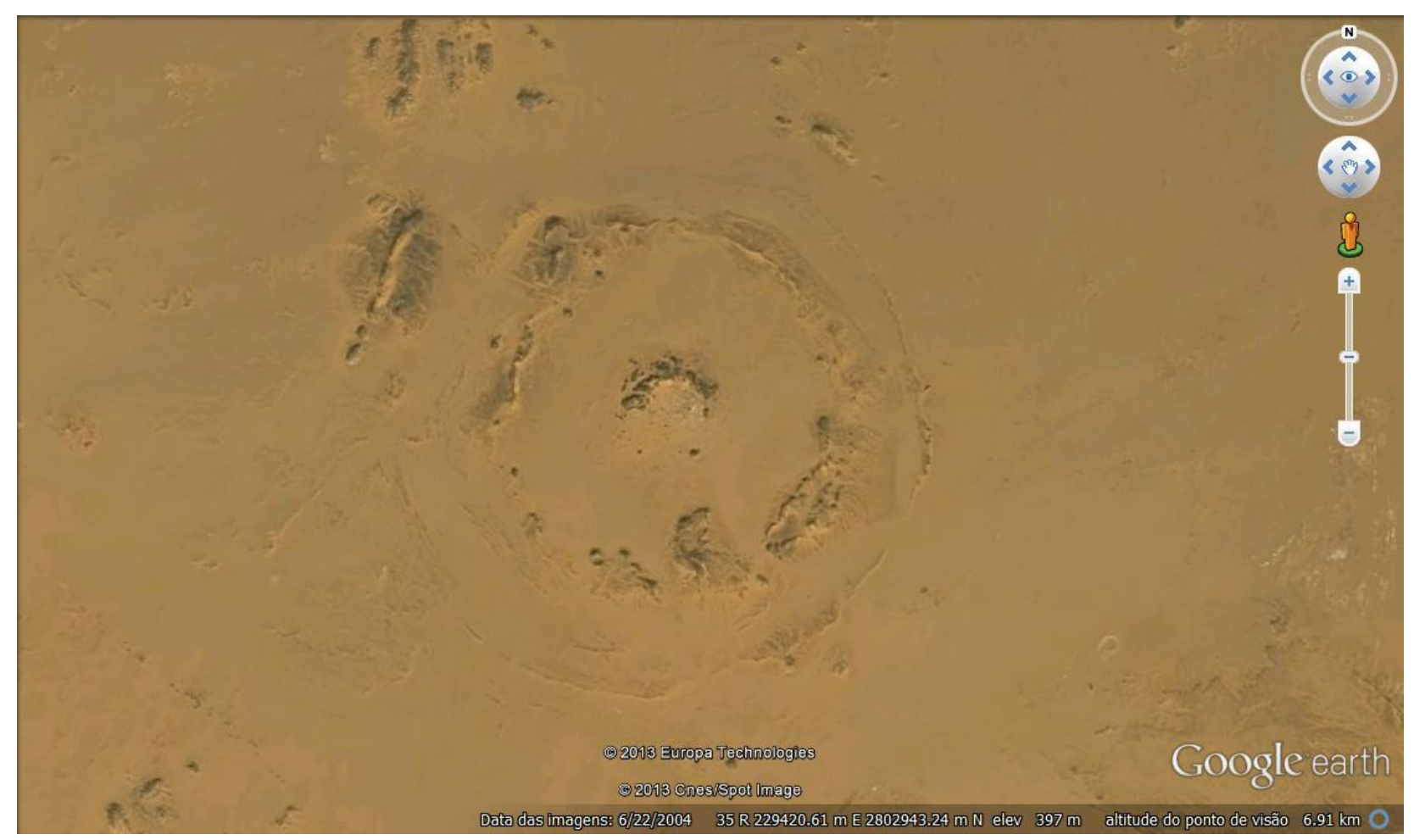

Figura 16 - Estrutura BP, na Líbia. Estrutura complexa cujo pico central, de maior resistência ao ataque erosivo, permanece como ressalto na paisagem. Obtida de: Google Earth, 2013, Fonte: CNES/Spot, 2005. 
Estruturas de impacto podem ainda ser envolvidas por uma zona de fraturas radiais e concêntricas (Figura 5). Tais descontinuidades constituem verdadeiras linhas de fraqueza ao trabalho erosivo, o que implica em um controle estrutural da drenagem e do relevo formado no entorno da cratera.

A expressão geológica dos maiores eventos de impacto, que resultam em estruturas complexas, atinge consideráveis profundidades sob o fundo original da cratera. Conforme Grieve (1993), diversas estruturas de impacto antigas de grandes dimensões, como Vredefort, na África do Sul (140 km de diâmetro), foram reconhecidas por meio do distúrbio geológico produzido pelo soerguimento central, mesmo que a cratera e todas as litologias da estrutura de impacto tenham sido destruídas. Dada a distribuição hemisférica das ondas de choque que escavam crateras de impacto, estima-se diâmetro maior para a cratera original de Vredefort, de cerca de $300 \mathrm{~km}$.

Quanto ao condicionamento morfoclimático, há importante contraste na evolução de estruturas de impacto em ambientes úmidos em relação às de ambientes secos. Nos primeiros, a deposição de sedimentos por processos fluviais e pluviais, ocorre sem contato com o exterior. Forma-se um ambiente propício à sedimentação contínua e isolada, favorecendo estudos paleoambientais, como aquele realizado por Ledru et al. (2005) na cratera de Colônia. O isolamento do ambiente sedimentar no interior da cratera está relacionado com a formação de uma drenagem inicialmente endorréica e conseqüente de ambiente lacustre. Já nos últimos, os sedimentos do interior da cratera podem ter também origem eólica, com contribuição de materiais provenientes do exterior da estrutura, como em Aouelloul, na Mauritânia (FUDALI e CRESSY, 1976).

À medida que os processos erosivos e sedimentares se processam, as feições herdadas do impacto tornam-se cada vez menos evidentes, até seu atual desvanecimento por total arrasamento ou por inumação. Neste último caso, existe a possibilidade de ulterior exumação. Esta condição seria necessária à preservação de estruturas de impacto muito antigas.

A formação e a evolução da estrutura de impacto também condiciona o desenvolvimento de redes de drenagem, por meio de fraturas e deformações produzidas nas rochas. O impacto de um bólido extraterrestre leva a uma modificação catastrófica da drenagem e, em poucos segundos, surge uma nova estrutura, impondo 
um novo arranjo à drenagem. A estrutura assim formada condiciona o desenvolvimento de canais consequentes, nas paredes dos aneis soerguidos, e subseqüentes, ao longo de fraturas, que se arranjam em um padrão de drenagem anelar, como já observado por Garvin et al. (1992).

Padrões fluviais tendem a ser persistentes, mesmo em termos de tempo geológico. Eles fornecem não apenas evidências de controle geológico por fraturas, dobras ou contatos litológicos, como podem ajudar na compreensão da cronologia geológica regional (TWIDALE, 2004). Portanto, trata-se de um importante instrumento de análise no estudo da geomorfologia desenvolvida em estruturas de impacto.

A rede de drenagem, apesar de persistente, está sujeita a modificações ao longo de sua evolução. Ramificações podem surgir e desaparecer e eventos climáticos ou tectônicos podem provocar rearranjos na drenagem, estes últimos compreendidos enquanto transferência de parte ou todo o fluxo de um rio para outro (BISHOP, 1995). O autor classifica os rearranjos em: capturas (interceptação dos canais em nível mais elevado por outros adjacentes em níveis mais baixos), desvios (migração ativa de um canal fluvial para níveis mais baixos) e decapitação (deslocamento dos divisores em função de processos de vertente associados à evolução da drenagem).

As diferenças de declividade entre a face externa e externa da crista da cratera podem gerar migração progressiva dos topos da crista circular. Em situações nas quais a face interna é a mais íngreme - mais comum devido à maior amplitude altimétrica no interior da cratera - a linha de cumeada da crista migra para o exterior, o que pode ser acompanhado da expansão da rede de drenagem interna, por decapitação, podendo ocasionar posterior captura de uma linha de drenagem externa, como na Cratera de Bosumtwi (JONES et al., 1981).

Com o nivelamento da estrutura de impacto, a drenagem tipicamente endorreica dos estágios iniciais de evolução das crateras de impacto (FUDALI et al., 1980; JONES et al., op cit) passa a exorreica, à medida que a crista se rebaixa e o interior é entulhado, criando condições para a abertura da drenagem (RICCOMINI et al., 1991). 


\section{MÉTODOS E TÉCNICAS}

A concretização dos objetivos da pesquisa se faz mediante emprego do raciocínio hipotético-dedutivo, tendo-se como pano de fundo as referências teóricas apresentadas. O método consiste na formulação e apresentação de hipóteses que tentam explicar lacunas no conhecimento sobre um determinado tema, seguida da dedução de suas consequências e finalmente da comparação dos fatos apreendidos pela observação com os fatos deduzidos a partir das hipóteses (KING, 1971).

Harvey (1969) apresenta os passos da rota de explicação dedutiva aplicada à Geografia, iniciada nas experiências perceptuais do sujeito, que elabora uma imagem da estrutura real do mundo, formulando um modelo a priori a partir do qual são formuladas hipóteses. As hipóteses implicam em uma sistemática de coleta de dados, que devem ser definidos, classificados e mensurados; desta etapa parte-se para os procedimentos de verificação dos dados, que incluem, por exemplo, obtenção de índices estatísticos. Se bem sucedida for a etapa de verificação, a hipótese pode dar lugar a leis e à construção de teorias; caso contrário, reformula-se o modelo a priori, iniciando-se novamente a sequência.

Como o estudo se realiza em uma área atingida por impacto meteorítico, a formulação de hipóteses a respeito do desenvolvimento do relevo na cratera de Colônia e entorno é embasada na contribuição de Melosh (1989) a respeito da formação e desenvolvimento de estruturas e crateras de impacto, além de outros trabalhos citados na Seção 2, referentes a essas feições. Busca-se, na descrição sistemática dos elementos geomorfológicos da cratera de Colônia e entorno, coletar dados que permitam corroborar ou refutar hipóteses geradas a partir dos modelos teóricos avaliados.

Para a análise do condicionamento estrutural e dinâmico sobre a rede de drenagem, adota-se a proposta metodológica de Oliveira (2003), que consiste no uso de fotointerpretação, análise de campo e morfometria para a descrição de elementos indicativos desse condicionamento, como: lineamentos, gargantas, colos e escalonamento de níveis topográficos. 
Utilizam-se como materiais da pesquisa: fotografias aéreas e estereoscópios, na etapa de fotointerpretação; trado, enxadão, bússola e GPS nas análises de campo; cartas topográficas digitalizadas, MDEs, cartas geológicas, produtos de estudos geofísicos e softwares de geoprocessamento nas análises de morfometria.

Emprega-se a técnica da fotointerpretação para a coleta de dados do relevo e da drenagem, com uso de estereoscópios de bolso e de espelho. Utilizam-se 21 fotografias aéreas, obtidas no aerolevantamento "Estado de São Paulo", de escala 1:25.000, realizado em 1962 pela empresa "IA", disponível no acervo do Laboratório de Aerofotogeografia e Sensoriamento Remoto do Departamento de Geografia da USP. A articulação das fotografias aéreas é apresentada na Figura 17, bem como as bordas da feição estudada: a cratera de Colônia e a zona de formas concêntricas em seu entorno. Justifica-se o uso da coleção de 1962 por conciliar boa resolução e pouca modificação das feições geomorfológicas pelo processo de urbanização ocorrido na região nos anos 1990.

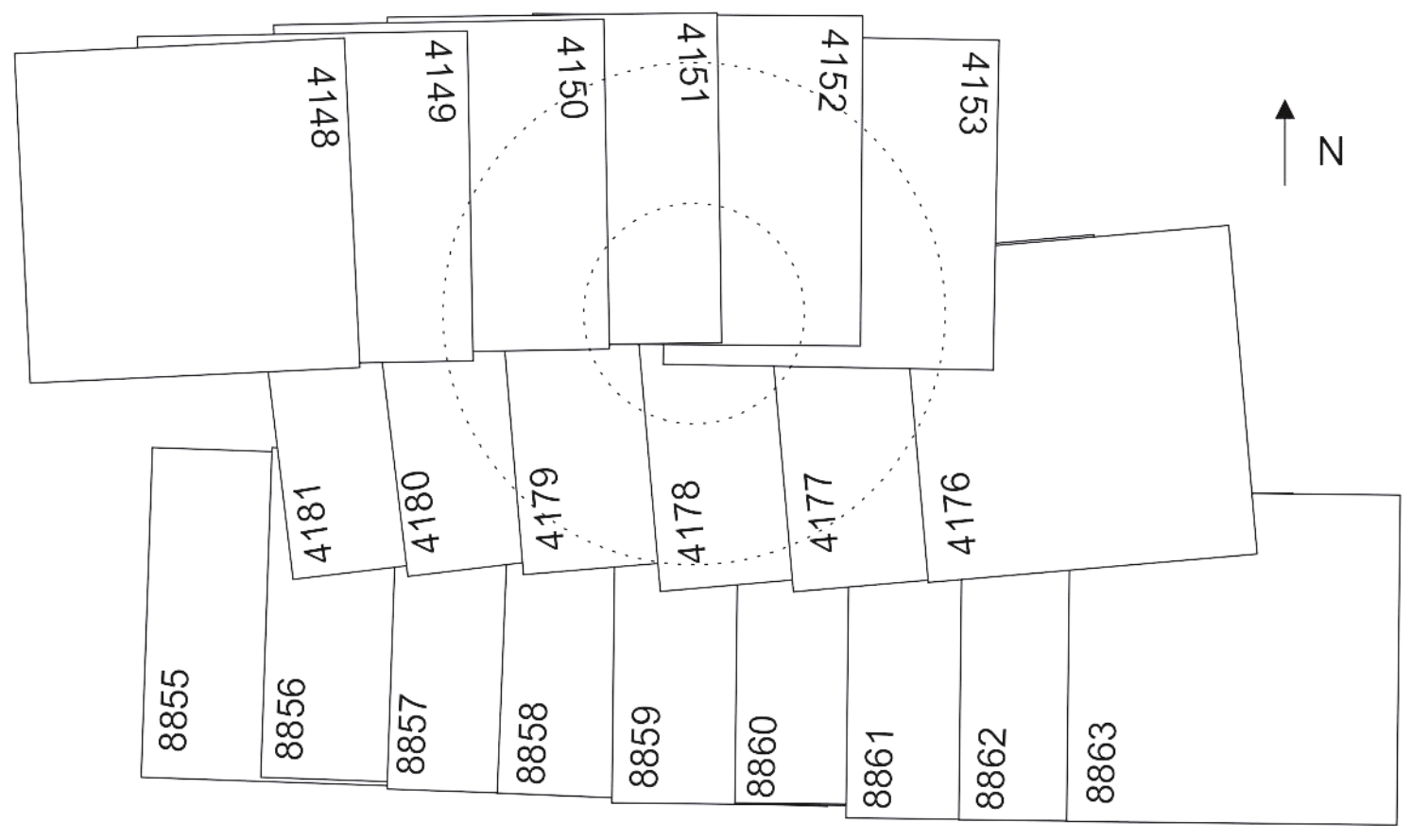

Escala das fotografias: 1:25.000

Dimensoes das fotografias: $23 \times 23 \mathrm{~cm}$

Figura 17 - Identificação e articulação das fotografias aéreas utilizadas na pesquisa, pertencentes à coleção "Estado de São Paulo", de escala 1:25.000, obtidas em 1962 pela empresa "IA". Fonte: Elaborada pelo autor. 
Após a restituição dos elementos do relevo e da drenagem por fotointerpretação, registrados nos overlays obtidos, elabora-se uma carta morfológica (Anexo 1), produto de base que visa fornecer uma descrição detalhada das formas do relevo e das linhas de drenagem da área. O mapeamento morfológico por fotointerpretação segue a proposta de Savigear (1965), partindo do pressuposto de que as superfícies planas e curvas que formam o relevo se unem em descontinuidades, ou rupturas de declividade, cujas características devem ser reconhecidas, mensuradas e mapeadas.

A simbologia adotada visa ressaltar as rupturas no relevo, de maneira clara e legível. Com esse objetivo, elaboram-se símbolos pontuais e lineares mais simples que os propostos pelo autor. Tendo-se em vista a grande complexidade morfológica da área, constituída por relevo bastante dissecado, a adoção de uma simbologia simplificada torna-se necessária. Seguem, no Quadro 1, as definições dos objetos mapeados e seus respectivos símbolos, conforme em Nunes et al. (1995) e Guerra e Guerra (2003).

\begin{tabular}{|l|l|l|}
\hline \multicolumn{2}{|c|}{ ELEMENTOS GEOMORFOLÓGICOS } \\
\hline & Vale em "V" & $\begin{array}{l}\text { Vale delimitado por vertentes relativamente } \\
\text { retilíneas que se encontram no talvegue, } \\
\text { sem ocorrência de área plana em seu } \\
\text { interior. }\end{array}$ \\
\hline \multirow{4}{*}{ Vale em berço } & Vale dissimétrico & $\begin{array}{l}\text { Vale delimitado por vertentes côncavas que } \\
\text { se encontram no talvegue, sem ocorrência } \\
\text { de área plana em seu interior. }\end{array}$ \\
\hline & Vale de fundo plano & $\begin{array}{l}\text { Vale delimitado por vertentes de } \\
\text { declividades de valores discrepantes. }\end{array}$ \\
\hline & $\begin{array}{l}\text { Vale delimitado por vertentes relativamente } \\
\text { retilíneas ou côncavas, separadas por uma } \\
\text { área plana que se delimita com as vertentes } \\
\text { por ruptura côncava. }\end{array}$ \\
\hline & $\begin{array}{l}\text { Ruptura de declividade } \\
\text { convexa }\end{array}$ & $\begin{array}{l}\text { Ruptura de declividade da vertente, na qual } \\
\text { a declividade aumenta do setor superior } \\
\text { para o inferior. }\end{array}$ \\
\hline \multirow{2}{*}{$\begin{array}{l}\text { Ruptura de declividade } \\
\text { convexa superior a 30\% }\end{array}$} & $\begin{array}{l}\text { Ruptura de declividade da vertente, na qual } \\
\text { a declividade aumenta abruptamente do } \\
\text { setor superior para o inferior, com } \\
\text { declividades superiores a 30\%. Sem } \\
\text { significado estrutural. }\end{array}$ \\
\hline
\end{tabular}




\begin{tabular}{|c|c|c|}
\hline & $\begin{array}{l}\text { Ruptura de declividade } \\
\text { côncava }\end{array}$ & $\begin{array}{l}\text { Ruptura de declividade da vertente, na qual } \\
\text { a declividade diminui do setor superior para } \\
\text { o inferior. }\end{array}$ \\
\hline H\#П\#\#\#11 & Crista & $\begin{array}{l}\text { Região alongada e estreita de níveis } \\
\text { altimétricos mais elevados que o entorno. }\end{array}$ \\
\hline 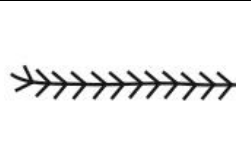 & Crista com caimento & $\begin{array}{l}\text { Região alongada e estreita de níveis } \\
\text { altimétricos mais elevados que o entorno, } \\
\text { decrescentes em um sentido. }\end{array}$ \\
\hline & Colo & $\begin{array}{l}\text { Depressão mais ou menos acentuada em } \\
\text { uma linha de cristas, dispostos entre dois } \\
\text { vales de direções opostas ou paralelas. }\end{array}$ \\
\hline & Terraço & $\begin{array}{l}\text { Superfície horizontal ou levemente } \\
\text { inclinada, constituída por depósito } \\
\text { sedimentar, ou superfície topográfica } \\
\text { modelada pela erosão fluvial, marinha ou } \\
\text { lacustre e limitada por dois declives do } \\
\text { mesmo sentido. Constitui um patamar que } \\
\text { interrompe um declive contínuo. }\end{array}$ \\
\hline \multicolumn{3}{|c|}{ HIDROGRAFIA } \\
\hline & Canal fluvial & $\begin{array}{l}\text { Local por onde escoam as águas fluviais, } \\
\text { sendo o fluxo de água perene ou } \\
\text { intermitente. }\end{array}$ \\
\hline & Lago & $\begin{array}{l}\text { Depressões do solo produzidas por causas } \\
\text { diversas e preenchidas por águas } \\
\text { confinadas, mais ou menos tranquilas, } \\
\text { geralmente alimentados por um mais rios } \\
\text { afluentes, podendo ter origem tectônica, } \\
\text { vulcânica, residual, de erosão, de barragem, } \\
\text { entre outros. }\end{array}$ \\
\hline \multicolumn{3}{|c|}{ ELEMENTOS LITO-ESTRUTURAIS } \\
\hline \multirow[t]{2}{*}{\begin{tabular}{|l|} 
\\
(em branco)
\end{tabular}} & $\begin{array}{l}\text { Litologias ígneas e } \\
\text { metamórficas sem } \\
\text { diferenciação }\end{array}$ & $\begin{array}{l}\text { Rochas ígneas e metamórficas mapeadas } \\
\text { na área, incluindo: granitos, dioritos, } \\
\text { migmatitos, gnaisses, xistos e anfibolitos. }\end{array}$ \\
\hline & Sedimentos terciários & $\begin{array}{l}\text { Remanescentes sedimentares de idade } \\
\text { Terciária, pertencentes à Bacia de São } \\
\text { Paulo, Formação Resende. }\end{array}$ \\
\hline & Sedimentos quaternários & $\begin{array}{l}\text { Depósitos sedimentares presentes na área } \\
\text { de idade Quaternária, produzidos por } \\
\text { deposição fluvial ou lacustre. }\end{array}$ \\
\hline & Falha indiscriminada & $\begin{array}{l}\text { Falha geológica sem discriminação quanto a } \\
\text { seu tipo (normal, inversa ou transcorrente) }\end{array}$ \\
\hline & $\begin{array}{l}\text { Foliação (mergulho de } 10 \text { a } \\
45^{\circ} \text { ) }\end{array}$ & $\begin{array}{l}\text { Estrutura, presente em rochas metamórficas } \\
\text { e ígneas, que constitui um tipo de arranjo } \\
\text { dos minerais ao longo de planos, formando } \\
\text { ângulo de } 10 \text { a } 45^{\circ} \text { em relação à superfície. }\end{array}$ \\
\hline
\end{tabular}




\begin{tabular}{|c|c|c|}
\hline & $\begin{array}{l}\text { Foliação (mergulho de } 45 \text { a } \\
80^{\circ} \text { ) }\end{array}$ & $\begin{array}{l}\text { Estrutura, presente em rochas metamórficas } \\
\text { e ígneas, que constitui um tipo de arranjo } \\
\text { dos minerais ao longo de planos, formando } \\
\text { ângulo de } 45 \text { a } 80^{\circ} \text { em relação à superfície. }\end{array}$ \\
\hline & $\begin{array}{l}\text { Foliação subvertical } \\
\text { (mergulho de } 80 \text { a } 90^{\circ} \text { ) }\end{array}$ & $\begin{array}{l}\text { Estrutura, presente em rochas metamórficas } \\
\text { e ígneas, que constitui um tipo de arranjo } \\
\text { dos minerais ao longo de planos, formando } \\
\text { ângulo de } 80 \text { a } 90^{\circ} \text { em relação à superfície. }\end{array}$ \\
\hline & Zona de falhas & $\begin{array}{l}\text { Zona linear na qual diversas falhas paralelas } \\
\text { são identificadas. }\end{array}$ \\
\hline \multicolumn{3}{|c|}{ ELEMENTOS PLANIMÉTRICOS } \\
\hline 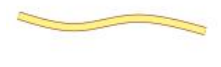 & Rua ou estrada & Vias de rodagem, pavimentadas ou não. \\
\hline$\approx$ & Ferrovia & $\begin{array}{l}\text { Vias compostas por trilhos, nos quais } \\
\text { trafegam veículos que dependem de } \\
\text { trajetórias de baixa declividade, daí a } \\
\text { formação de cortes e aterros. }\end{array}$ \\
\hline$\triangle 1111 D$ & Corte & $\begin{array}{l}\text { Corte realizado em uma encosta pela ação } \\
\text { do homem, normalmente para implantação } \\
\text { de estradas, ferrovias ou edificações. }\end{array}$ \\
\hline$\triangle 111 D$ & Aterro & $\begin{array}{l}\text { Preenchimento de uma área deprimida por } \\
\text { materiais, normalmente para implantação de } \\
\text { estradas, ferrovias ou edificações. }\end{array}$ \\
\hline
\end{tabular}

Quadro 1 - Simbologia adotada na Carta Morfológica e definições dos objetos mapeados. Fonte: Elaborada pelo autor.

A carta morfológica também apresenta dados sobre o embasamento geológico, conforme mapeamento efetuado por Emplasa e Coutinho (198?)2, em escala 1:50.000. As unidades terciárias e quaternárias são destacadas com tons de amarelo, respectivamente mais escuro e mais claro. A distribuição dessas unidades sedimentares tem importante significado no entendimento da evolução geomorfológica da área, tratando-se de remanescentes da Bacia de São Paulo, degradada em função da atividade erosiva de origem fluvial. As unidades cristalinas, por sua vez, constituem o fundo branco do mapa, sem diferenciação, para evitar incorrer na poluição visual. Essa generalização não prejudica a interpretação, uma

\footnotetext{
${ }^{2}$ Não há informação a respeito do ano em que o mapa foi publicado, apenas da década. Ele apresenta modificações em relação ao mapeamento elaborado por Coutinho (1980), na escala 1:100.000, como um detalhamento maior dos remanescentes terciários na área.
} 
vez que há pouca precisão nos limites entre as unidades litológicas do embasamento cristalino, evitando-se também uma falsa percepção de precisão do mapeamento litológico.

O controle de campo, efetuado nas etapas subsequentes, visa confirmar elementos visuais descritos na fotointerpretação, descrever materiais sub-superficiais e estabelecer relações entre estes e a morfologia. Para tanto, são percorridas as estradas principais e secundárias que atravessam a área estudada.

Constituem limitações às atividades de campo na área: as condições meteorológicas instáveis típicas da região, dificultando o acesso e a permanência, além das más condições de conservação ou não-pavimentação de algumas estradas, principalmente as que dão acesso ao setor meridional da área estudada. Por outro lado, a localização da área em pleno município de São Paulo constituiu elemento facilitador aos trabalhos de campo.

A etapa posterior consistiu na elaboração e análise de Modelos Digitais de Elevação (MDEs). Um MDE é uma representação numérica do relevo, composta por células ou pixels, cada uma com um valor de elevação em relação a um nível de referência, de coordenadas previamente estabelecidas, formando uma superfície contínua (CHAPLOT et al., 2006).

Para elaboração dos MDEs, utilizam-se dados vetoriais georreferenciados do relevo, nas escalas 1:10.000 (EMPLASA, 1980) e 1:50.000 (IBGE, 1980) e dados matriciais SRTM, com 90 m de resolução espacial, disponibilizados na página "Brasil em Relevo" da Embrapa na Internet (EMBRAPA, 2012).

Nas análises dos MDEs, empregam-se ferramentas de geoprocessamento disponíveis em três softwares livres: SPRING versão 5.2.1, LandSerf versão 2.3, e ILWIS versão 3.6, explorando as diferentes potencialidades de cada um dos programas.

Adota-se o SPRING para o georreferenciamento dos overlays obtidos na fotointerpretação. Trata-se de uma etapa complexa, pois as imagens nas fotografias aéreas apresentam distorções radiais, que devem ser corrigidas no processo de compatibilização com os dados já armazenados dos MDEs. Os arquivos gerados são exportados para análise no ILWIS. 
Já o LandSerf, software desenvolvido especificamente para a análise de MDEs, é utilizado para a elaboração das cartas hipsométrica, clinográfica e de orientação de vertentes. O programa também se mostra eficiente na elaboração de perfis topográficos, gerados instantaneamente com o arraste do mouse sobre o MDE. Para a introdução de informações geológicas no perfil, realiza-se consulta manual à carta geológica (EMPLASA e COUTINHO, 198?). Representam-se os mergulhos das foliações dos gnaisses e micaxistos com uso das hachuras, orientadas, na representação, na mesma direção do mergulho.

Efetua-se a maior parte das análises com uso do ILWIS, desenvolvido para processamento de imagens, análise espacial e mapeamento digital. Nesse software, executam-se, com uso do MDE de escala 1:10.000: mensurações morfométricas, análise das rupturas de declividade, fatiamento do relevo, análise de lineamentos, análise de anomalias de drenagem, análises hipsométricas e cálculos de densidade de drenagem. Utiliza-se o MDE de escala 1:50.000 para análise de orientações do relevo e elaboração de perfis topográficos em escala regional. Por fim, o modelo SRTM foi utilizado para análises hipsométricas envolvendo grandes áreas, como no caso das análises envolvendo as áreas totais das bacias do Jurubatuba, Embu-Guaçu e Capivari.

As mensurações morfométricas visam fornecer uma descrição quantitativa do relevo, com valores de entalhamento dos vales, dimensões interfluviais e níveis altimétricos. Também realizam-se medidas específicas da cratera de Colônia e dos limites da zona de formas concêntricas em seu entorno, com ajustamento de elipses e descrição de seus comprimentos de eixo maior, eixo menor e razão eixo maior / eixo menor.

O fatiamento do relevo, ou representação separada de níveis hipsométricos específicos, objetiva propiciar observação das características da morfologia concêntrica da superfície no entorno da cratera, considerando que os vales e as cristas que fazem parte dessa feição são mais marcadas em níveis específicos.

A análise das rupturas de declividade é utilizada na caracterização da influência da suposta estrutura de feições concêntricas na formação do relevo, considerando que as descontinuidades estruturais e litológicas geram rupturas de declividade, mapeadas tanto na fotointerpretação como na análise de MDE de escala 1:10.000. 
A análise de lineamentos também tem por objetivo descrever as influências das estruturas geológicas no desenvolvimento do relevo e da drenagem. Como as linhas de fraqueza estruturalmente geradas são retilíneas, ou curvilíneas em maiores distâncias, elas produzem também retilíneos na drenagem a elas adaptada e rupturas retilíneas nas vertentes.

Para a etapa da análise de lineamentos, delimitam-se trechos retilíneos dos canais fluviais obtidos na fotointerpretação e trechos retilíneos do relevo conforme descrito no MDE de escala 1:10.000. As frequências da ocorrência de direções específicas são analisadas com elaboração de diagramas de roseta, para comparação com as frequências das orientações de estruturas geológicas mapeadas.

A etapa também inclui a mensuração da frequência de canais orientados radial e paralelamente à borda da cratera e a elaboração de um mapa exibindo esses canais. Com esse mapeamento, pode-se inferir inclusive o posicionamento das possíveis estruturas geradas pelo evento que formou a cratera de Colônia.

A análise de anomalias de drenagem visa identificar knickpoints, wind gaps e inflexões abruptas nas trajetórias dos canais fluviais. Knickpoint é o nome dado a uma seção mais íngreme do perfil longitudinal de um rio, gerado por tectônica, mudança climática, contato litológico ou rearranjo de drenagem, fazendo o rio divergir de seu perfil de equilíbrio (AHNERT, 1998, p. 178), com tendência à migração para montante, devido à maior velocidade do fluxo de água e à maior capacidade erosiva do rio (GOUDIE, 2004). Wind gap, ou vale seco, designa uma seção de um vale no qual o rio que o formou não está mais presente, tendo sido capturado por outro sistema fluvial, podendo se encontrar imediatamente adjacente ao ponto da captura ou mais distante, devido à formação de um canal obsequente a partir do ponto da captura (SMALL, 1977, p. 244). Já as inflexões abruptas são trechos dos canais fluviais que descrevem curvas abruptas em ângulos próximos de 90ำ ou superiores, podendo indicar controle estrutural ou captura fluvial (SMALL, op cit, p. 242).

Os knickpoints são identificados por meio da aplicação do Índice SL (slope vs. lenght), proposto por Hack (1973), a perfis longitudinais (Figura 18). O Índice é aplicado aos rios principais de sub-bacias de quarta ordem, identificados conforme Horton (1945). Já a hierarquia das sub-bacias é determinada conforme o método de Strahler (1952). 
Os wind gaps e as inflexões abruptas são delimitados visualmente, na observação da carta de drenagem, obtida por fotointerpretação, sobreposta às curvas de nível do MDE de escala 1:10.000.

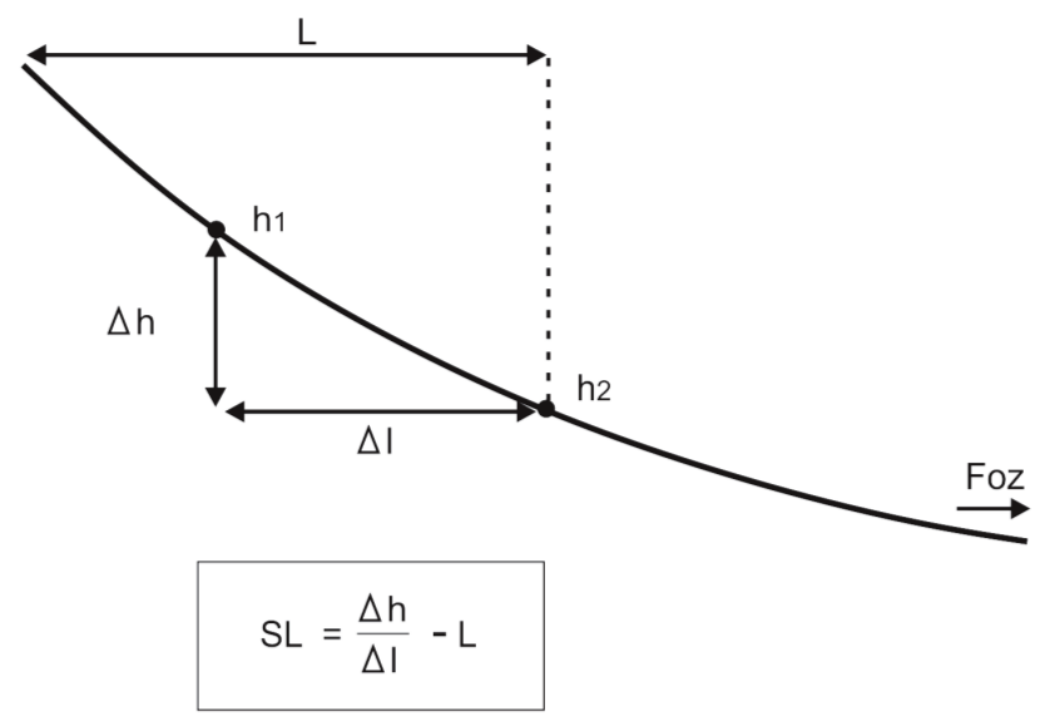

Figura 18 - Obtenção do Índice SL para um segmento de drenagem. $\Delta \mathrm{h}=$ diferença de altitude entre duas curvas de nível, $\Delta l=$ projeção horizontal do comprimento do segmento de canal fluvial entre duas curvas de nível, $L=$ comprimento desde a nascente do canal fluvial. Fonte: Souza et al., 2011.

As análises hipsométricas visam definir as proporções ocupadas pelas diferentes faixas hipsométricas em determinada área da superfície terrestre (CHRISTOFOLETTI, 1980, p. 117). São obtidos dois produtos dessa análise: a curva hipsométrica, que representa graficamente a área proporcional da bacia acima de cada valor altimétrico proporcional (de 0 a 1); e a integral hipsométrica $(\mathrm{HH})$, correspondente à área sob a curva hipsométrica (de 0 a 1), calculada segundo a fórmula:

$$
I H=\left(E_{\text {média }}-E_{\text {min }}\right) /\left(E_{\text {máx }}-E_{\text {min }}\right)
$$

onde $E_{\text {média }}=$ valor médio de elevação, $E_{\max }=$ valor máximo de elevação $E_{\min }=$ valor mínimo de elevação (elevação no exutório), para cada bacia. 
Esses índices são usados para a interpretação do estágio do trabalho erosivo e, em alguns casos, da interação entre denudação e soerguimento tectônico. A forma da curva indica o grau de desenvolvimento da bacia: perfis convexos indicam grande proporção de material nos níveis mais elevados, ao passo que perfis côncavos indicam predominância das menores elevações, sugerindo que mais material foi removido pelos processos fluviais (COOLEY, 2013). Deste modo, quanto menor o valor integral hipsométrica, maior a quantidade de material removido por processos fluviais.

Efetua-se, por fim, o cálculo da densidade de drenagem (Dd) de cada subbacia, índice que correlaciona o comprimento total dos canais fluviais com a área da bacia hidrográfica, pela equação:

$$
D d=\frac{L_{t}}{A}
$$

onde $L_{t}=$ comprimento total dos canais e $A$ = área da bacia (CHRISTOFOLETTI, 1980, p. 115-6). Segundo o autor, em um mesmo ambiente climático, as propriedades hidrológicas da litologia interferem no índice de densidade de drenagem, de tal modo que em litologias mais propícias à infiltração, há menor escoamento superficial, com a produção de uma rede de canais menos densa. Já nas unidades litológicas que dificultam a infiltração, o maior escoamento superficial gera uma rede de canais mais densa. 


\section{4. ÁREA DE ESTUDO}

O estudo dos condicionantes estruturais da drenagem e do relevo na Cratera de Colônia e entorno abrange parcela significativa do setor meridional do Planalto Paulistano, no reverso da escarpa da Serra do Mar. Encontram-se ali os distritos de Parelheiros e Marsilac, no município de São Paulo (SP), onde há redes de drenagem possivelmente influenciadas pelo impacto que gerou a cratera e que participaram ativamente na elaboração de seu modelado.

A escala mais geral de análise abrange a totalidade das bacias hidrográficas dos rios Jurubatuba, Embu-Guaçu e Capivari e é delimitada pelas coordenadas geográficas $47^{\circ} \mathrm{O}, 2^{\circ} 12^{\prime} \mathrm{S}$ e $46^{\circ} 20^{\prime} \mathrm{O}$ e $23^{\circ} 35^{\prime} \mathrm{S}$. Já as feições de maior interesse ao estudo, descritas mais detalhadamente, são compreendidos pelas coordenadas geográficas $46^{\circ} 46^{\prime} \mathrm{O}, 2^{\circ} 56^{\prime} \mathrm{S}$ e $46^{\circ} 36^{\prime} \mathrm{O}$ e $23^{\circ} 49^{\prime} \mathrm{S}$ (Mapa 1).

Apresenta-se uma descrição do quadro natural da região de Colônia, com base na literatura, objetivando contextualizar os resultados da presente pesquisa. Ampliase e atualiza-se a descrição apresentada por Santos (2009).

\subsection{ASPECTOS LITO-ESTRUTURAIS}

A região de Colônia situa-se na Faixa Dobrada do Ribeira (HASUI, 1975). Sua estrutura geológica resulta de diversas fases de sedimentação e de deformação tectônica que remontam ao Proterozóico, com formação de falhamentos transcorrentes dextrais e subverticais de grande profundidade em rochas metassedimentares.

Esses fenômenos foram desencadeados durante diversas fases orogenéticas diacrônicas do Ciclo Brasiliano-Pan-Africano (880 a $480 \mathrm{Ma})$, vinculados à aglutinação de massas continentais na formação da Gondwana e ao desenvolvimento de extensas cordilheiras. A fase orogenética se encerrou com o colapso extensional, registrado em falhas cisalhantes transversais aos orógenos (HEILBRON et al., 2004). 


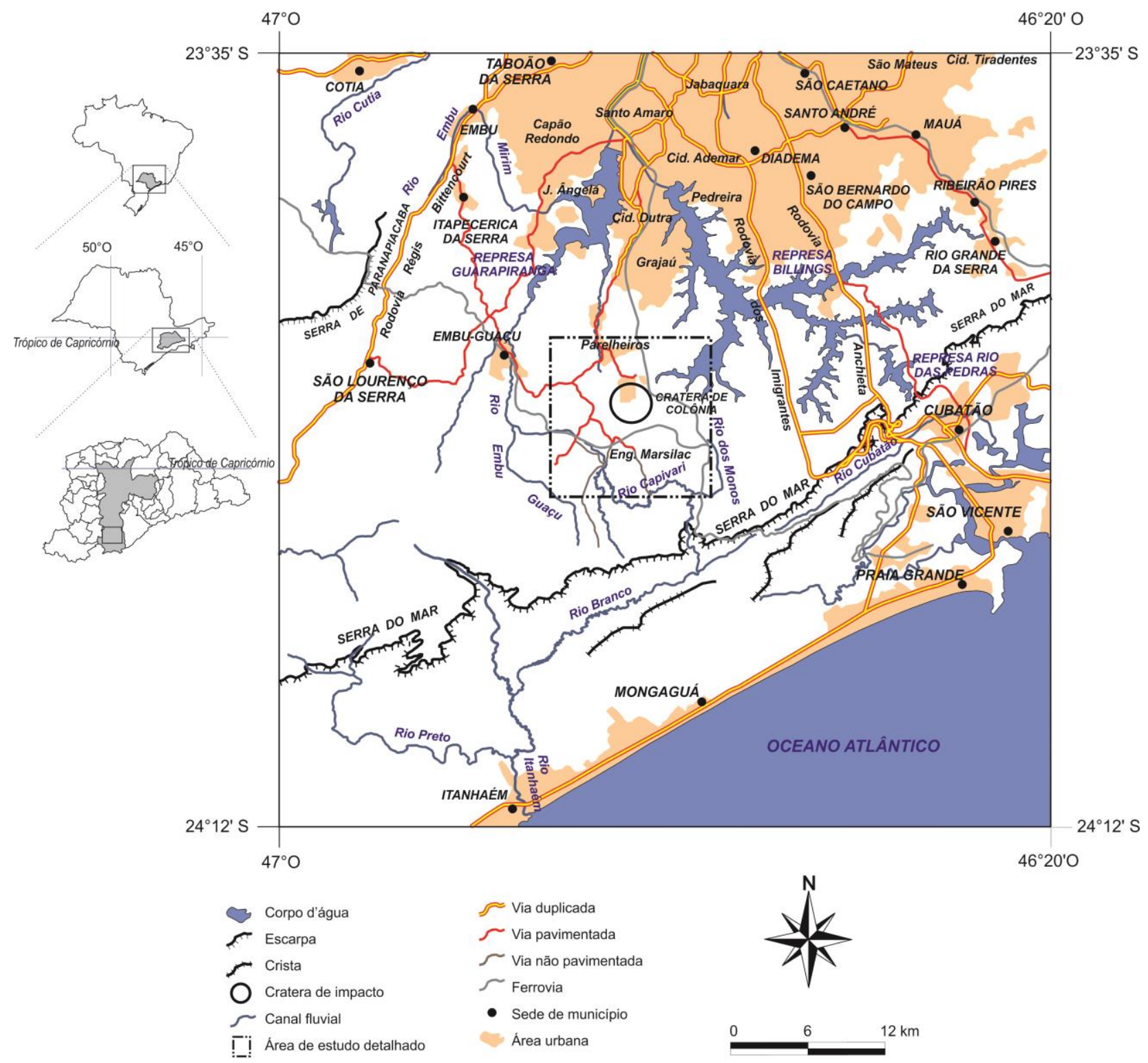

Mapa 1 - Localização da área de estudo, com elementos topográficos e planimétricos. Dados: IBGE, 1984; Google Maps, 2009, disponível em <http://maps.google.com>. Acesso em 17 out 2009. Fonte: Elaborado pelo autor.

Do Paleozóico ao Mesozóico, estabeleceu-se uma fase de relativa quiescência tectônica, com uma sucessão de extensos períodos erosivos (ROSS e MOROZ, 1997). Desse período ao início do Cenozóico, formou-se a Superfície Japi (ALMEIDA, 1964), correspondente à porção paulista da Superfície das Cristas Médias de De Martonne ou ao Peneplano Eocênico de Morais Rego (AB'SÁBER, 1957). A superfície seria indicada pelo nivelamento dos topos das serras quartzíticas a noroeste da Bacia de São Paulo e das cimeiras das regiões da Serra do Mar e da Mantiqueira. 
Ao final dessa fase, processou-se a Reativação Wealdeniena (ALMEIDA, 1967), ou Epirogênese Pós-Cretácica (AB'SÁBER, 1949), que consistiu no soerguimento da Plataforma Sul-Americana em decorrência dos processos tectônicos que levaram à ruptura do supercontinente Gondwana e à abertura do Oceano Atlântico Sul. Este evento teve seu início marcado pelo vulcanismo basáltico da Formação Serra Geral (RICCOMINI et al., 2004).

A consequente reativação dos falhamentos formados no Ciclo Brasiliano-PanAfricano causou basculamento e formação de uma grande depressão tectônica que se estendeu por aproximadamente $1.000 \mathrm{~km}$, do Rio de Janeiro ao Paraná, conhecida por Rift Continental do Sudeste do Brasil, conforme proposto por Riccomini (1989). Ao se instalar, no Paleógeno, o rifte teria deformado a superfície Japi, a partir da reativação das falhas pré-cambrianas (RICCOMINI et al., op cit).

Desenvolveu-se, no interior do rifte, um conjunto de áreas de sedimentação, formando as bacias de Volta Redonda, Resende, Taubaté e São Paulo, esta última com prolongamentos na região de Parelheiros. Essas bacias teriam se isolado posteriormente em decorrência do tectonismo deformador do rifte (RICCOMINI, 1998). A ideia contraria a interpretação de Ab'Sáber (1957), segundo a qual nunca teria havido ligação pretérita entre as bacias de São Paulo e de Taubaté.

Riccomini et al. (op cit) apresentam uma cronologia dos movimentos tectônicos mais recentes, que remontam ao Mioceno, época em que teriam ocorrido movimentos transcorrentes sinistrais. No Plioceno, haveria um segundo evento deformador, responsável pelo afeiçoamento dos altos estruturais que separaram os sedimentos paleogênicos em bacias distintas, a partir de falhas normais ou inversas. Um terceiro evento, do Pleistoceno tardio ao Holoceno, seria responsável pelo contorno atual da distribuição de sedimentos e pela reativação de falhas inversas de direção norte-sul, gerando famílias conjugadas de cisalhamento em depósitos colúvio-aluviais.

A distribuição espacial das unidades geológicas da área é apresentada no Mapa 2. O substrato geológico local é bastante heterogêneo. O conjunto litológico principal é constituído por xistos, gnaisses e granitos, seccionados por falhas e fraturas da Faixa Dobrada do Ribeira, recobertos localmente por remanescentes terciários da Bacia Sedimentar de São Paulo e por sedimentos aluviais quaternários. 


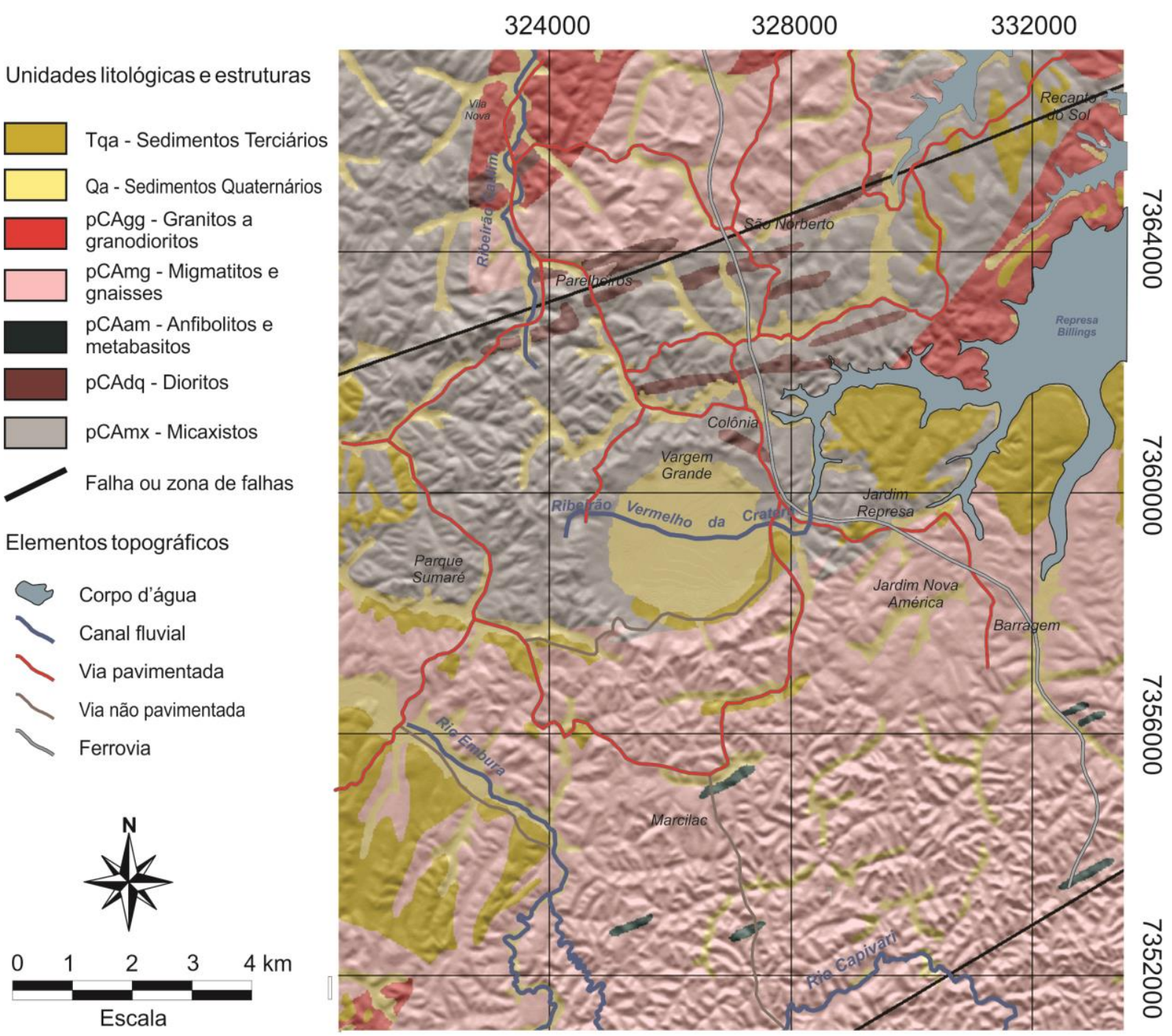

Mapa 2 - Geologia da área de estudo sobreposta ao modelo sombreado. Embasamento préCambriano constituído principalmente por migmatitos e gnaisses (ao sul) e micaxistos (ao norte). Cobertura sedimentar Terciária descontínua, remanescente da sedimentação oligocênica que resultou na Formação Resende. Fonte: Coutinho, 1980; Emplasa, 1984. Fonte: Elaborado pelo autor.

Compõem o embasamento geológico pré-cambriano da região as seguintes unidades litológicas, segundo Coutinho (1980), pertencentes ao Complexo Embu:

- PCegm - gnaisses graníticos e biotita-gnaisses, migmatizados, subordinadamente miloníticos. Ocorrem no extremo meridional da área, nas cabeceiras do rio Capivari.

- PCex - xistos: biotita-quartzo-muscovita-xistos, granada-biotita-xistos, micaxistos diversos, parcialmente migmatizados. Ocorrem corpos lenticulares 
de anfibolitos, quartzitos e rochas calciossilicatadas. Constituem a maior parte do embasamento pré-cambriano da região de Parelheiros.

- PCef - filitos e subordinadamente sericita-xistos e micaxistos. Compreendem faixa localizada a norte do núcleo urbano principal de Parelheiros.

Suítes Graníticas Indiferenciadas:

- PCgg - granitos, granodioritos, monzogranitos, granitóides indiferenciados, equigranulares ou porfiróides, em grande parte gnáissicos, sin- e póstectônicos.

As rochas apresentam metamorfismo crescente do interior do planalto à escarpa da Serra do Mar, dada a exposição de camadas mais profundas para sul (ALMEIDA, 1964).

Heilbron et al. (2004) observam a grande dificuldade de individualização de unidades estratigráficas nas regiões de metamorfismo de alto grau, por isso formando "complexos". Esta dificuldade gerou imprecisões nas cartas geológicas utilizadas, o que demandou aferições em campo.

As estruturas rúpteis são muito frequentes e incluem falhas, juntas e foliações.

Grandes falhas de direção geral leste-nordeste seccionam a região, como as falhas de: Taxaquara, Caucaia, Jundiuvira, Cubatão, entre outras, compreendidas na Zona de Transcorrência de São Paulo (HASUI, 1975). As falhas locais, de natureza transcorrente, inversa ou normal, correspondem aos eventos tectônicos apresentados por Riccomini et al. (2004).

Três famílias de juntas são descritas por Ribeiro (2003): de alto mergulho, com direção longitudinal, transversal ou oblíqua à direção geral da foliação; inclinadas, de direção preferencial NE-SW, provavelmente geradas no Mesozóico; e de baixa inclinação, mais ou menos paralelas à superfície, geradas por alívio de carga pela erosão.

Já a foliação geral das rochas segue a direção geral NE-SW, aproximadamente paralela à linha de costa, com mergulhos variáveis, normalmente para Sudeste. 
A Bacia Sedimentar de São Paulo, por sua vez, é composta pelas seguintes unidades geológicas, conforme Riccomini et al. (2004):

- Formação Resende, de idade eocênica a oligocênica, unidade basal do Grupo Taubaté, compreende depósitos proximais em relação à borda norte da Bacia de São Paulo (sedimentos arenosos e cascalhosos de sistema de leques aluviais associados a planícies aluviais de rios entrelaçados) e distais (predominância de lamitos, podendo ocorrer lentes arenosas e conglomerados de sistema fluvial entrelaçado);

- Formação Tremembé, oligocênica, compõe-se de depósitos argilosos e rítmicos que evidenciam ambiente deposicional lacustre do tipo playa-lake, sendo presente na Bacia de São Paulo em sua faixa centro-setentrional;

- Formação São Paulo, neo-oligocênica, compõe-se de depósitos arenosos, siltosos e argilosos de sistema fluvial meandrante, possui distribuição muito mais restrita na Bacia de São Paulo.

Dos sedimentos que constituem a Bacia de São Paulo, identificam-se na área apenas os da Formação Resende, presentes principalmente no vale do Rio Embura, na borda da Cratera de Colônia, na proximidade da represa Billings e em pequenas unidades isoladas no interior da unidade de relevos concêntricos que circunda a cratera. No entanto, Riccomini et al. (1991) descrevem gnaisses imbricados com sedimentos argilosos correlacionados à Formação São Paulo, ao sul da cratera de Colônia.

Capeando rochas do embasamento cristalino e sedimentos terciários, as unidades aluviais quaternárias (Qa) são encontradas nas planícies fluviais dos principais rios da região, como o Embu-Guaçu, o Jurubatuba, o Caulim, o Capivari e - Embura e estão sujeitas a inundações periódicas, salvo ao longo dos terraços fluviais (ROSS e MOROZ, 1997).

Sob ponto de vista geotécnico, descrevem-se as camadas da Bacia de São Paulo, da base para o topo: 1) areias grossas basais amarelas avermelhadas, abaixo da cota $720 \mathrm{~m}$;2) argilas duras cinza esverdeadas, adensadas pelo peso das camadas sobrejacentes, evidenciando paleolago de dimensões indefinidas; 3) argilas rijas, siltes e areias finas de cores variegadas, que ocorrem principalmente na área central 
da bacia, sustentando terraços que circundam o espigão central; 4) argilas duras vermelhas e amarelas, que ocorrem no espigão da Avenida Paulista, sob um manto laterítico de "argila porosa" com aproximadamente $8 \mathrm{~m}$ de espessura; 5) solos argilosos vermelho amarelos, desenvolvidos nas camadas argilosas subjacentes (VARGAS, 2002).

\subsection{ASPECTOS CLIMÁTICOS E PALEOCLIMÁTICOS}

Os climas regionais do sudeste brasileiro são descritos e analisados por Nunes et al. (2009). Sua posição geográfica, na borda oriental da América do Sul, atravessada pelo Trópico de Capricórnio se traduz por um considerável fluxo de energia ao longo do ano, distribuição espaço-temporal bastante irregular das precipitações, elevada precipitação nos setores continentais e setentrionais e participação de sistemas anticiclonais, contribuindo para a grande variabilidade de regimes climáticos da região. Na fachada litorânea do Estado de São Paulo, a presença de barreiras orográficas à brisa marítima produz distúrbios na circulação do ar e aumenta a pluviosidade. Trata-se de uma área de conflito entre massas de ar distintas, com invasão de sistemas mais frios provenientes do Sul, contrastantes com as massas mais quentes, criando condições para a ocorrência de tornados e trombas d'água

À escala local, ocorrem na região de Colônia duas unidades climáticas "naturais": o Clima Tropical Sub-oceânico Super-úmido do Reverso do Planalto Atlântico, a Norte, e o Clima Tropical Oceânico Super-úmido da Fachada Oriental do Planalto Atlântico, a Sul (Mapa 3). Definidas por Tarifa e Armani (2002), constituem as áreas de maior umidade e pluviosidade do município de São Paulo. A primeira apresenta temperaturas médias anuais máximas entre $24,9^{\circ} \mathrm{C}$ e $25,2^{\circ} \mathrm{C}$ e mínimas entre $15,3^{\circ} \mathrm{C}$ e $15,8^{\circ} \mathrm{C}$ e totais pluviométricos anuais entre $1.400 \mathrm{~mm}$ e $1.800 \mathrm{~mm}$. A segunda unidade apresenta temperaturas médias anuais máximas entre $24,9^{\circ} \mathrm{C}$ e $28^{\circ} \mathrm{C}$ e mínimas entre $15,3^{\circ} \mathrm{C}$ e $18^{\circ} \mathrm{C}$ e totais pluviométricos anuais entre 1.600 e 2.210 mm. Ribeiro (2003) ressalta a importância do relevo na circulação atmosférica local, já que a escarpa da Serra do Mar interfere na dinâmica de avanços e recuos de frentes, bem como da brisa marítima. Trata-se de uma das áreas de maior pluviosidade do país, com chuvas concentradas no verão. 


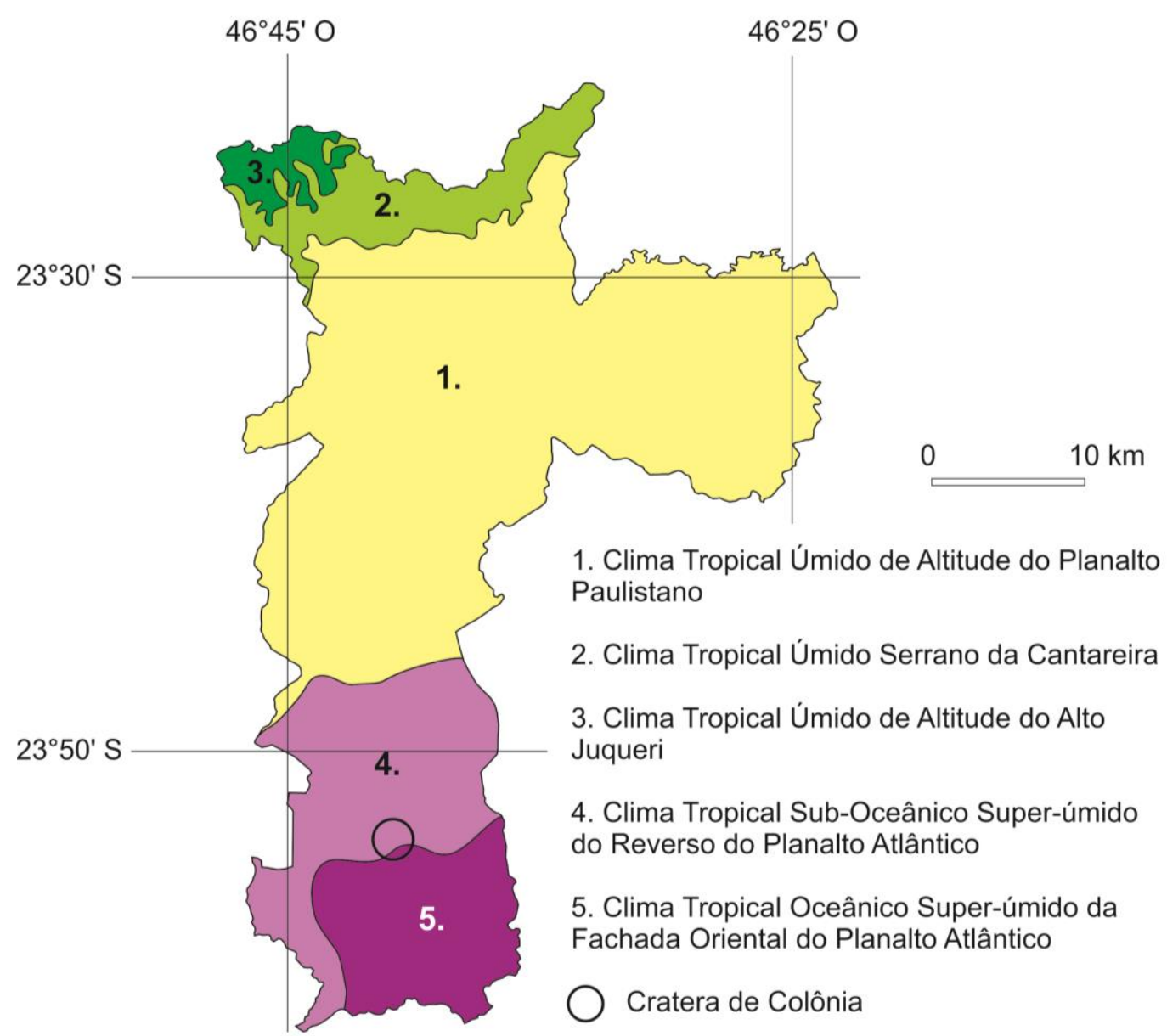

Mapa 3 - Climas naturais no Município de São Paulo. Destaque para as unidades 4 e 5, presentes na área de estudo. Fonte: Tarifa e Armani, 2002. Modificado pelo autor.

Santos (2012) elabora uma análise de magnitude-frequência dos eventos pluviométricos aplicada à região de Colônia, utilizando dados de 22 postos pluviométricos, de 1979 a 1984, a partir dos quais foram obtidos os valores de $\mathrm{Y}$ a $\mathrm{A}$ ( $Y=$ intervalo de recorrência em 1 ano; $Y+A=$ intervalo de recorrência em 10 anos) que compõem o Índice de Magnitude-Frequência. A análise revela frequência elevada de eventos chuvosos intensos, especialmente nas proximidades da escarpa da Serra do Mar (Mapas 4 e 5 e Gráfico 2). Tal proximidade sugere influência decisiva da escarpa na distribuição das precipitações pela região. 


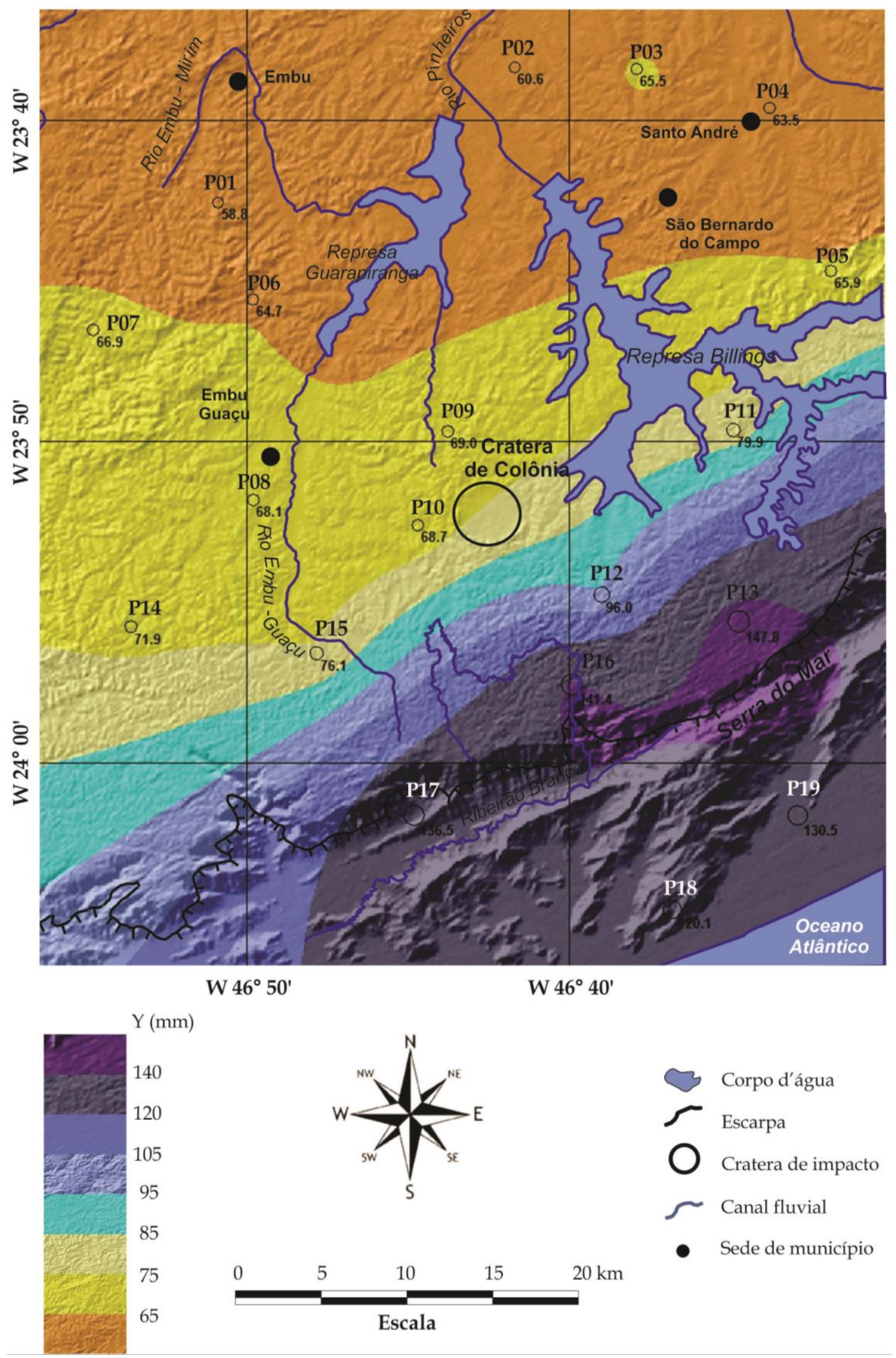

Mapa 4 - Carta de isovalores da constante $Y$ da equação de estimativa da magnitudefrequência das precipitações na região de Parelheiros, São Paulo-SP. Extraído de Santos, 2012. 


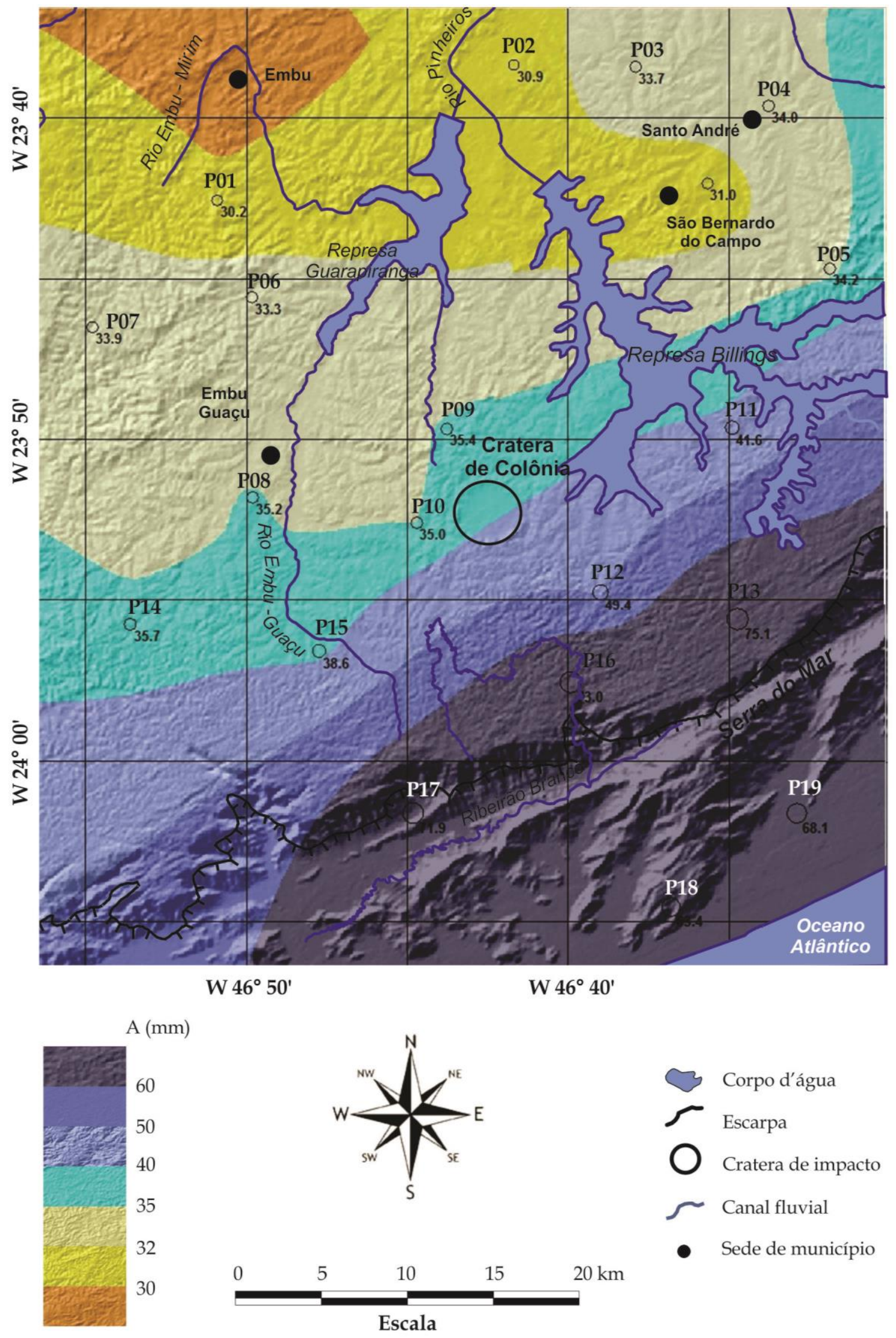

Mapa 5 - Carta de isovalores da constante A da equação de estimativa da magnitudefrequência das precipitações na região de Parelheiros, São Paulo-SP. Extraído de Santos, 2012. 


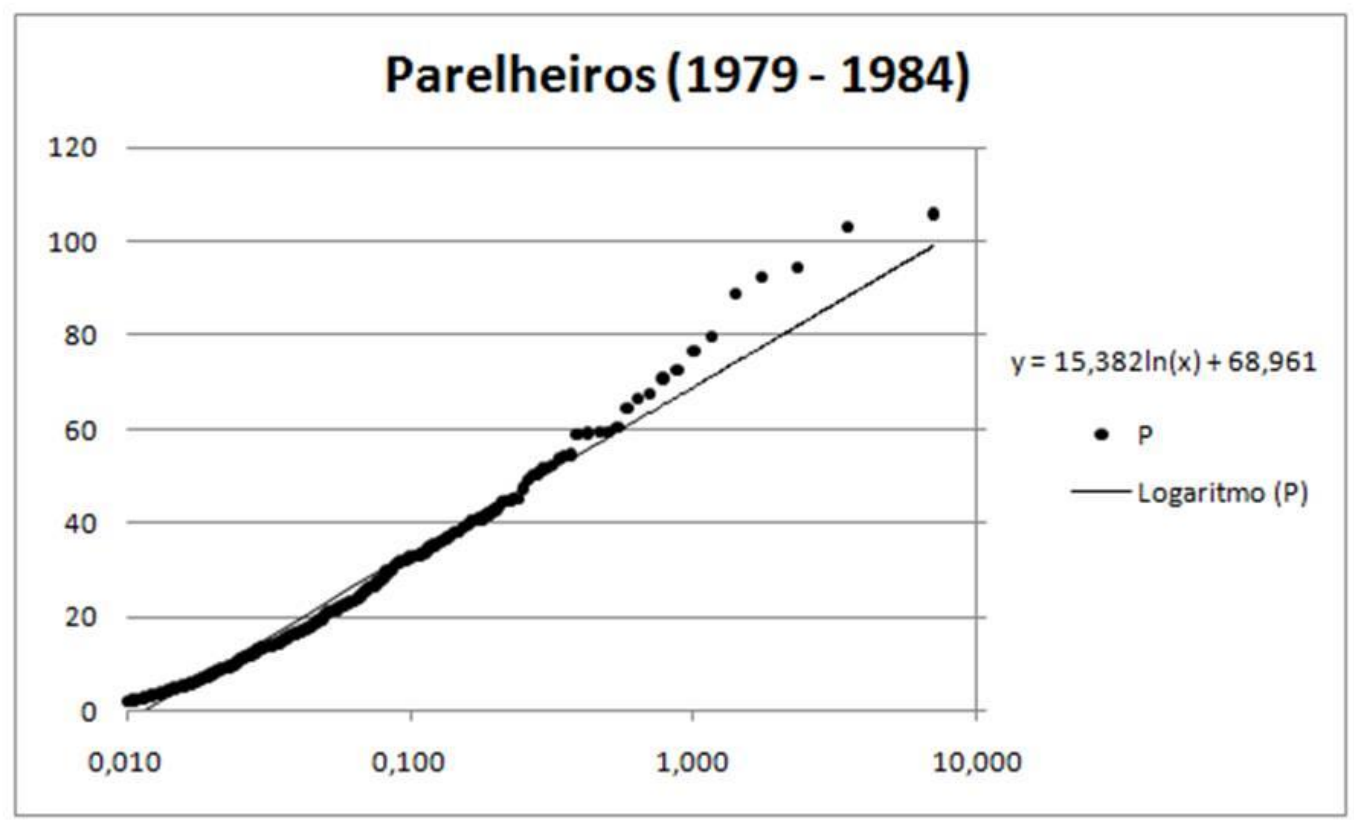

Gráfico 2 - Estimativa de Magnitude-Frequência das chuvas no posto Parelheiros, município de São Paulo-SP, próximo à cratera de Colônia. Extraído de Santos, 2010.

Ledru et al. (2005) investigam as variações da cobertura vegetal no Pleistoceno, concentrando-se nos últimos 100.000 anos, examinando o registro sedimentar contido na Cratera de Colônia, rico em matéria orgânica (Gráfico 3). No estudo, constatam que houve baixa frequência de espécies arbóreas há 30.000 e há 10.000 anos, ao passo que expansões florestais ocorreram há 20.000 e 5.000 anos. Uma grande frequência de arbóreas também foi observada há mais de 85.000 anos. Considerando que nos trópicos as baixas frequências de arbóreas são associadas a períodos secos, uma vez que as temperaturas não declinam suficientemente para constituir o principal fator limitante ao seu desenvolvimento, concluem que o clima deve ter sido relativamente mais seco na região durante as últimas glaciações. 


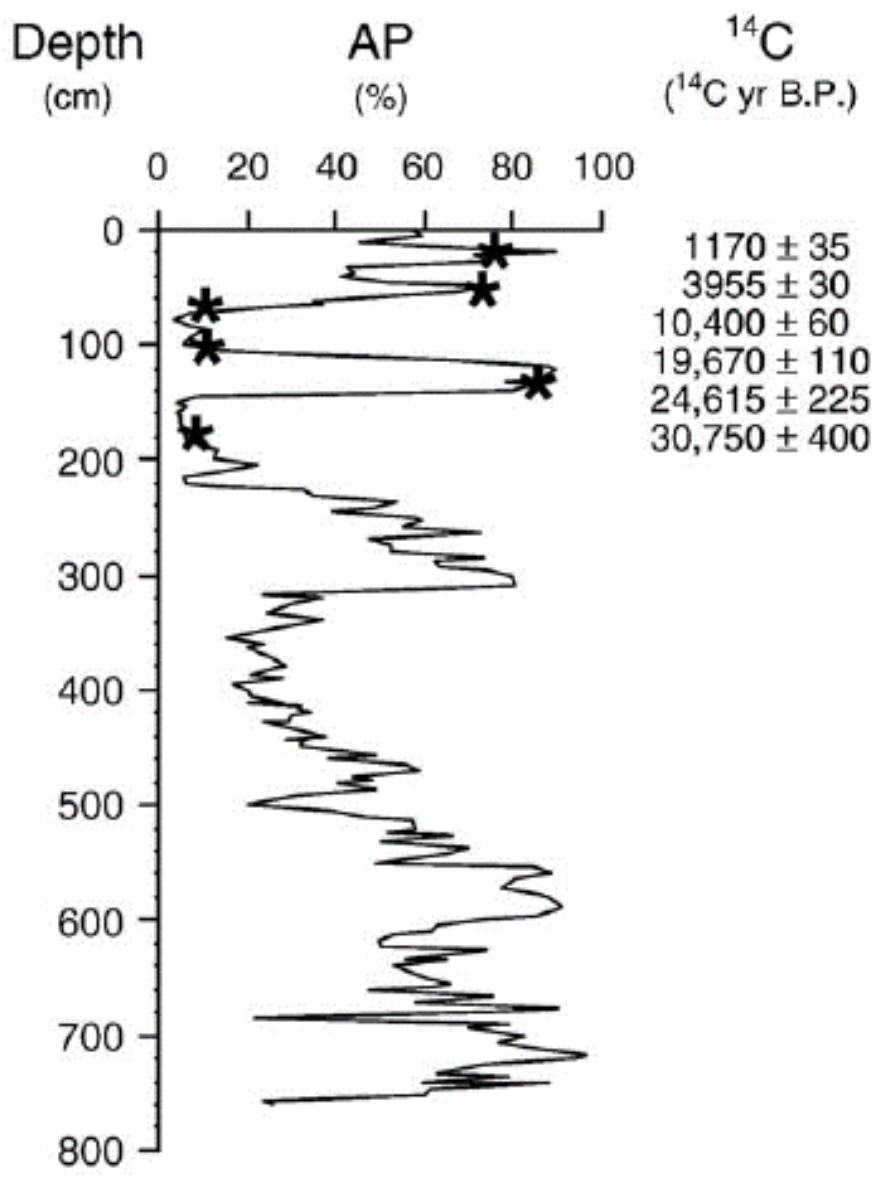

Gráfico 3 - Percentagem de pólens arbóreos por profundidade, com indicação das datações obtidas por radiocarbono. As variações da cobertura florestal ao longo dos últimos 100.000 anos, conforme estimado pelo estudo de Ledru et al. (2005), são atribuídas a variações climáticas, com fases secas correlacionadas a estágios glaciais e fases úmidas correlacionadas a estágios interglaciais. Extraído de Ledru et al., 2005.

\subsection{ASPECTOS HIDROGRÁFICOS}

A hidrografia da região meridional do Planalto Paulistano se distribui em duas grandes redes distintas. A primeira, mais extensa, dirige-se para o interior do continente, indo de encontro ao rio Tietê, seguindo pelo rio Paraná e alcançando o Oceano Atlântico após mais de $3.000 \mathrm{~km}$ de percurso. A segunda compreende as pequenas bacias hidrográficas que se dirigem diretamente para o litoral, atravessando a escarpa da Serra do Mar e atingindo a costa após cortarem a estreita planície litorânea de pouco menos de $30 \mathrm{~km}$ de largura. O divisor de águas entre os dois 
grandes conjuntos se localiza no reverso da Serra do Mar, a uma distância variável da escarpa de centenas de metros a dezenas de quilômetros.

Na região de Colônia, a rede hidrográfica coleta águas para o Alto Tietê por intermédio dos tributários do rio Pinheiros, como o rio Embu-Guaçu e o rio Jurubatuba atualmente com seus baixos cursos inundados pelas Represas Guarapiranga e Billings, respectivamente. O rio Capivari, por sua vez, reúne a drenagem da região de Marsilac, dirigindo-a para o Oceano Atlântico através dos rios Branco e Itanhaém, já na Planície Litorânea (Mapa 6).

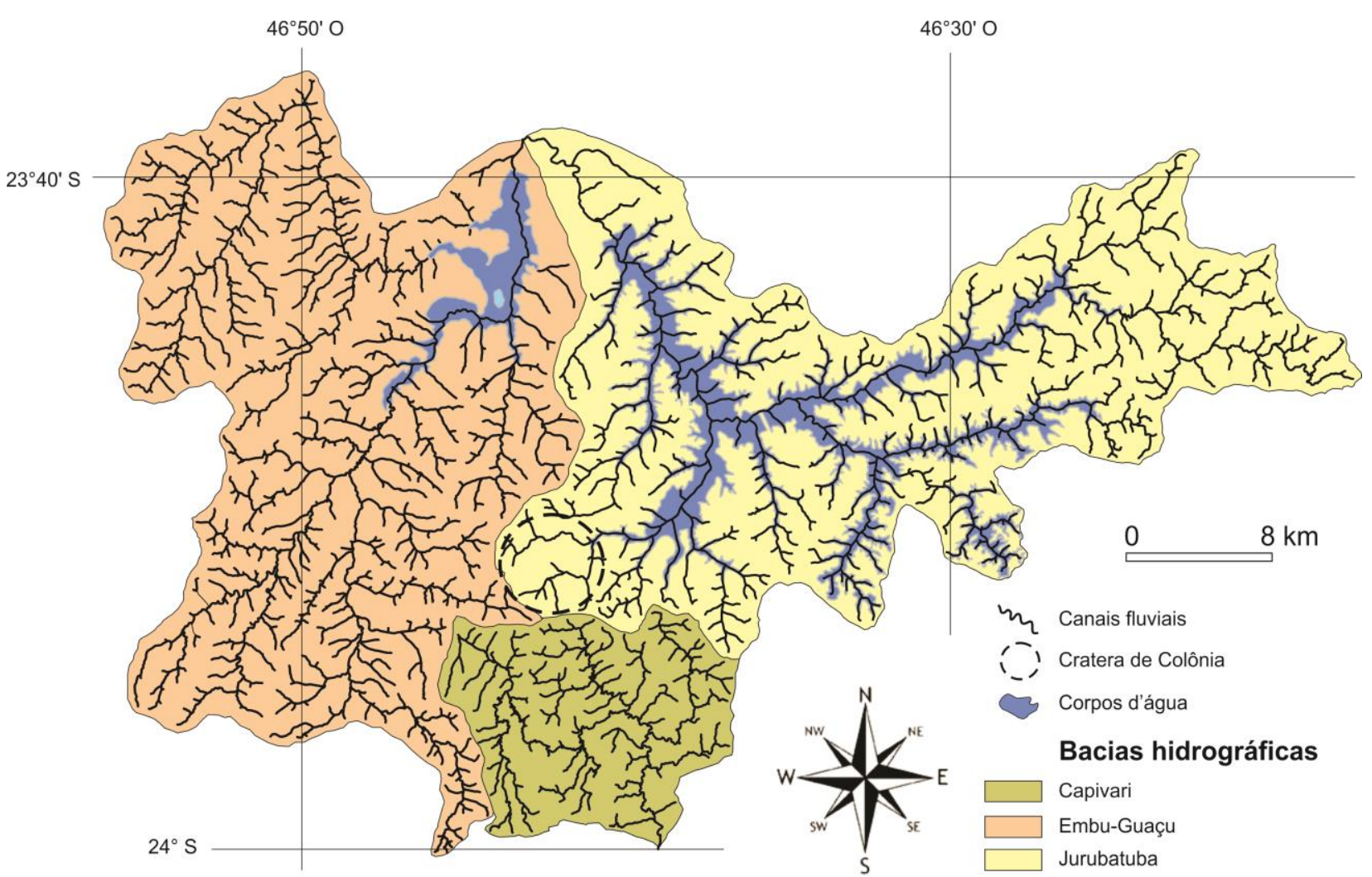

Mapa 6 - Bacias hidrográficas dos rios Capivari, Embu-Guaçu e Jurubatuba, que drenam a superfície da cratera de Colônia e de terrenos adjacentes. Cursos d'água extraídos de carta topográfica de escala 1:50.000. Excluem-se da representação os canais de primeira ordem, conforme Strahler (1952). Dados: IBGE, 1984. Elaborado pelo autor.

Conforme Ab`Sáber (1957), o desenvolvimento da drenagem é posterior à sedimentação paleogênica no domínio da Bacia Sedimentar de São Paulo. No exterior da bacia sedimentar, por sua vez, encontram-se traços hidrográficos antecedentes ao 
ciclo deposicional regional, mais diretamente relacionados com os lineamentos estruturais dos maciços antigos, já que a área não fora recoberta pelos referidos sedimentos.

A perenidade é característica até para os menores ramos das redes hidrográficas da região, as quais se apresentem altamente dendritificadas e muito densas (AB'SÁBER, 1966). Ocorrem, frequentemente, planícies alveolares em pontos de concentração de drenagem ou à montante de soleiras. Esse fato é especialmente observado na bacia do rio Capivari.

Das três bacias que drenam a área, a do rio Capivari é a de menor extensão, com aproximadamente $151 \mathrm{~km}^{2}$. Em terrenos de gnaisses migmatizados com fraturas e foliações seguindo a direção preferencial para leste-nordeste, o padrão de drenagem é bastante influenciado pela estrutura geológica, com trechos retilíneos também na direção leste-nordeste. Constitui-se como a bacia de maior densidade de drenagem, dadas a densa rede de fraturas do embasamento cristalino e os altos índices pluviométricos anuais, superiores a $1.400 \mathrm{~mm}$. A rede hidrográfica apresenta vestígios de forte dinamismo, com grande quantidade de colos e de inflexões, que constituiriam evidências de rearranjos de drenagem recentes.

As águas da bacia do rio Embu-Guaçu dirigem-se para o rio Pinheiros e sua área é de aproximadamente $400 \mathrm{~km}^{2}$. Possui grande diversidade litológica, com gnaisses, granitos, xistos e coberturas sedimentares terciárias e quaternárias. Grande parte da bacia já esteve recoberta por sedimentos da Bacia de São Paulo, restando atualmente apenas unidades isoladas remanescentes e prolongamentos do núcleo principal. Para Ab'Sáber (1957), as principais linhas de drenagem, de sentido sul-norte constituem trechos superimpostos à direção geral das estruturas geológicas. Outras linhas de drenagem acompanham a direção geral das foliações, de direção nordeste.

Por fim, a bacia do rio Jurubatuba, que também se dirige para o rio Pinheiros, é a mais extensa das três, com cerca de $592 \mathrm{~km}^{2}$. Em área de gnaisses e micaxistos, os rios Grande e Pequeno, formadores do Jurubatuba, acompanham a direção geral da drenagem regional, que não teria sido recoberta por sedimentos Cenozóicos relacionados à Bacia de São Paulo (AB'SÁBER, 1957). Eles teriam sido capturados pela drenagem da bacia em formação, passando a fornecer sedimentos a esta. Após a captura, o nível de base dos rios teria rebaixado cerca de 100 metros, acelerando a erosão do relevo a leste da região. 


\subsection{ASPECTOS GEOMORFOLÓGICOS}

A área de estudo compreende o setor meridional do Planalto Paulistano (ALMEIDA, 1964), no reverso da escarpa da Serra do Mar. Apresenta-se, a seguir, um breve quadro a respeito dos conhecimentos sobre a origem do relevo dessas duas unidades geomorfológicas.

\subsubsection{O Planalto Paulistano}

Há duas interpretações a respeito da origem do relevo do Planalto Paulistano (Mapa 7), ambas com forte viés davisiano. Ab'Sáber (1957) propõe que uma superfície de erosão cretácica, de extensão generalizada no Planalto Atlântico, manifestada nas cristas de mais alta elevação da região, teria se degradado para formar uma superfície neogênica de extensão restrita à região de São Paulo. Já Almeida (1964) sugere uma superfície paleogênica, com remanescentes atuais muito mais restritos e que, por sua vez, se degradaria na superfície neogênica.

A superfície mais antiga, denominada Japi por Almeida (op cit), caracteriza-se pelo nivelamento dos topos das serras quartzíticas a noroeste da Bacia de São Paulo e das cimeiras das regiões da Serra do Mar e da Mantiqueira. $O$ autor admite idade eocênica para a superfície, uma vez que ela nivela intrusões alcalinas desta época. A Superfície Japi corresponde, segundo Ab'Sáber (op cit), à porção paulista da superfície das Cristas Médias de De Martonne ou ao Peneplano Eocênico de Morais Rego.

Ab'Sáber (op cit) menciona ainda uma "peneplanização local quaternária no reverso da Serra do Mar", onde se localiza a Cratera de Colônia. Na área, haveria um relevo em estágio avançado de desenvolvimento em relação ao restante do planalto, com traços de "senilidade". As plataformas interfluviais, rebaixadas ao extremo, formando baixas colinas cristalinas e vales com pequenas planícies aluviais, evidenciariam o estágio avançado da evolução da área. Não haveria na área vestígios da Superfície das Cristas Médias ou da Superfície de São Paulo, mas níveis locais muito mais recentes. 


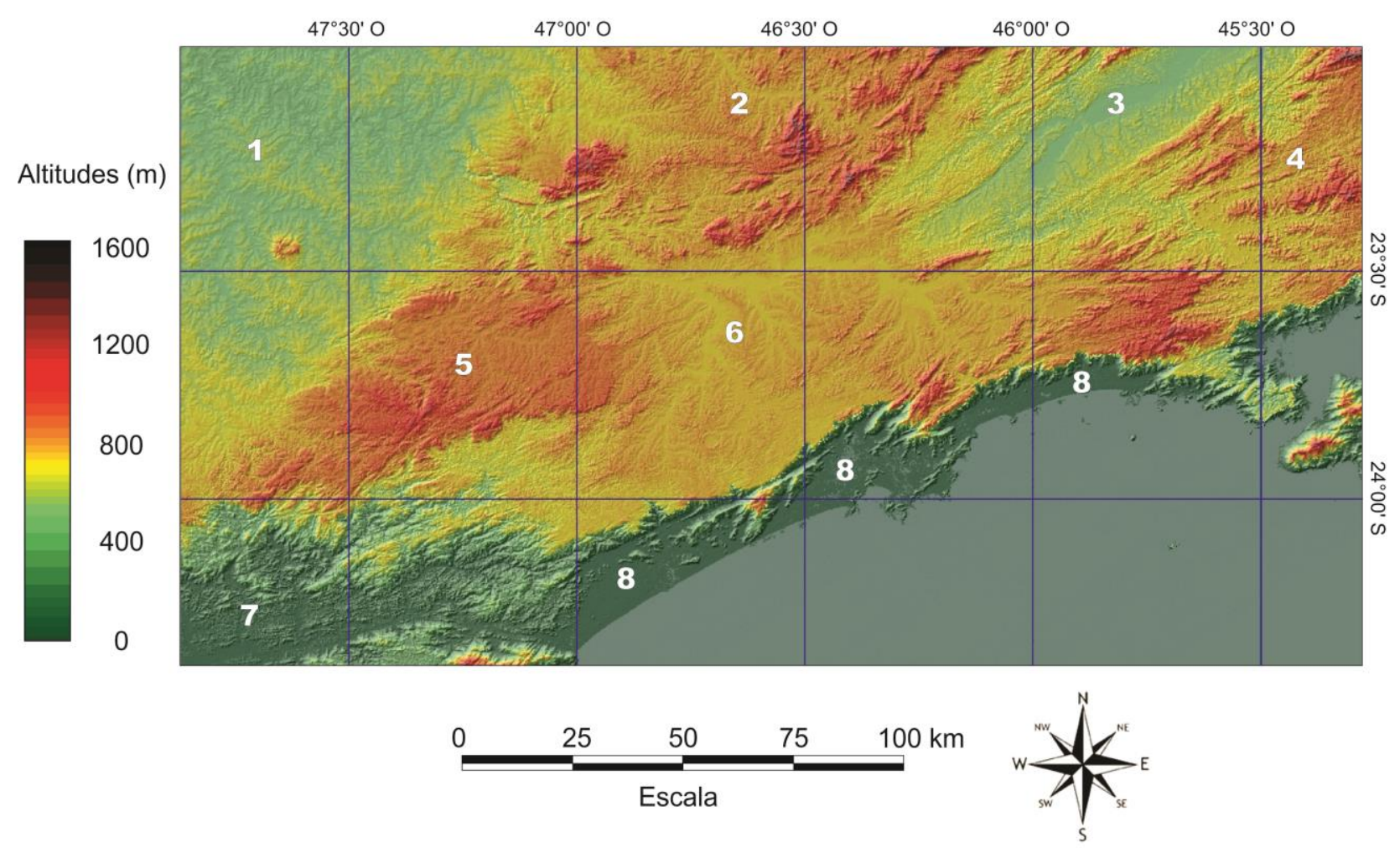

Mapa 7 - Compartimentos geomorfológicos da região de São Paulo e arredores, conforme Ross e Moroz (1997). Unidades morfológicas - 1: Depressão do Médio Tietê, 2: Planalto de Jundiaí, 3: Depressão do Médio Paraíba, 4: Planalto de Paraibuna, 5: Planalto de Ibiúna, 6: Planalto Paulistano, 7: Depressão do Médio Ribeira, 8: Planícies Litorâneas. Dados: SRTM/Embrapa, 2009. Elaborado pelo autor.

Para Ross (1991), à luz dos conhecimentos mais recentes, não é mais possível interpretar os diferentes níveis topográficos do leste paulista como associados diretamente às superfícies de erosão. Os níveis altimétricos diferenciados podem se associar a diversas gêneses, como: o tectonismo cenozóico, que por meio de basculamentos, provocou o posicionamento de blocos em diferentes níveis altimétricos; a resistência diferencial das rochas frente aos processos de erosão física ou química; ou os fechos de sedimentação, que balizam os topos de colinas sedimentares terciária. Sugere-se, ainda, que as datações das Superfícies das Cristas Médias e de São Paulo - ou a de Japi e a do Alto Tietê - poderiam pertencer à mesma fase erosiva e que a tectônica neogênica teria provocado sua deformação.

Römer (2008) também considera questionável a interpretação dos níveis topográficos na área como remanescentes de superfícies mais antigas e entende a concordância dos níveis de cumeada como resultante do ajuste de longo prazo das 
vertentes à incisão fluvial e à influência dos controles litológico e estrutural nos compartimentos tectônicos.

No quadro atual do Planalto Paulistano, predominam formas de relevo denudacionais em colinas e morros médios e altos com topos convexos, formando um conjunto altamente dissecado, com vales entalhados e densidade de drenagem média a alta. As altimetrias predominantes variam de 800 a $1.000 \mathrm{~m}$, sendo mais comuns as declividades entre 10 e $20^{\circ}$ (ROSS e MOROZ, 1997).

Há uma grande diferenciação morfológica entre áreas cobertas por sedimentos e aquelas nas quais o embasamento cristalino se encontra exposto. Sobre os sedimentos terciários, desenvolvem-se colinas relativamente amplas, com topos convexos, vertentes pouco inclinadas e baixa densidade de drenagem. Já nas áreas cristalinas, observa-se a predominância de morros de topos convexos e aguçados, com vertentes muito íngremes e alta densidade de drenagem. A dimensão interfluvial tende a diminuir, de norte a sul, no domínio do embasamento cristalino.

\subsubsection{A escarpa da Serra do Mar}

Ao sul do Planalto Paulistano encontra-se a Serra do Mar, a mais destacada feição geomorfológica da borda atlântica do continente sul-americano. Trata-se de um conjunto de escarpas festonadas que se estende dos estados do Rio de Janeiro a Santa Catarina, com aproximadamente $1000 \mathrm{~km}$ de extensão (ALMEIDA e CARNEIRO, 1998), sustentadas por uma diversidade de rochas cristalinas dobradas e fraturadas da Província Mantiqueira (HEILBRON et al., 2004).

Sua origem foi atribuída por De Martonne (1933) apud Almeida e Carneiro (1998) a um fraturamento em blocos estreitos de falha que teriam sofrido abatimento em direção à Baixada Santista, no sítio atual da escarpa. Já Almeida e Carneiro (op cit) interpretam a origem da escarpa como resultado de movimentações tectônicas ocorridas na Falha de Santos, mais a leste, com posterior recuo erosivo que alcançou a Falha de Cubatão, atual posição da escarpa na borda do Planalto Paulistano (ALMEIDA, 1964) (Figura 19). 

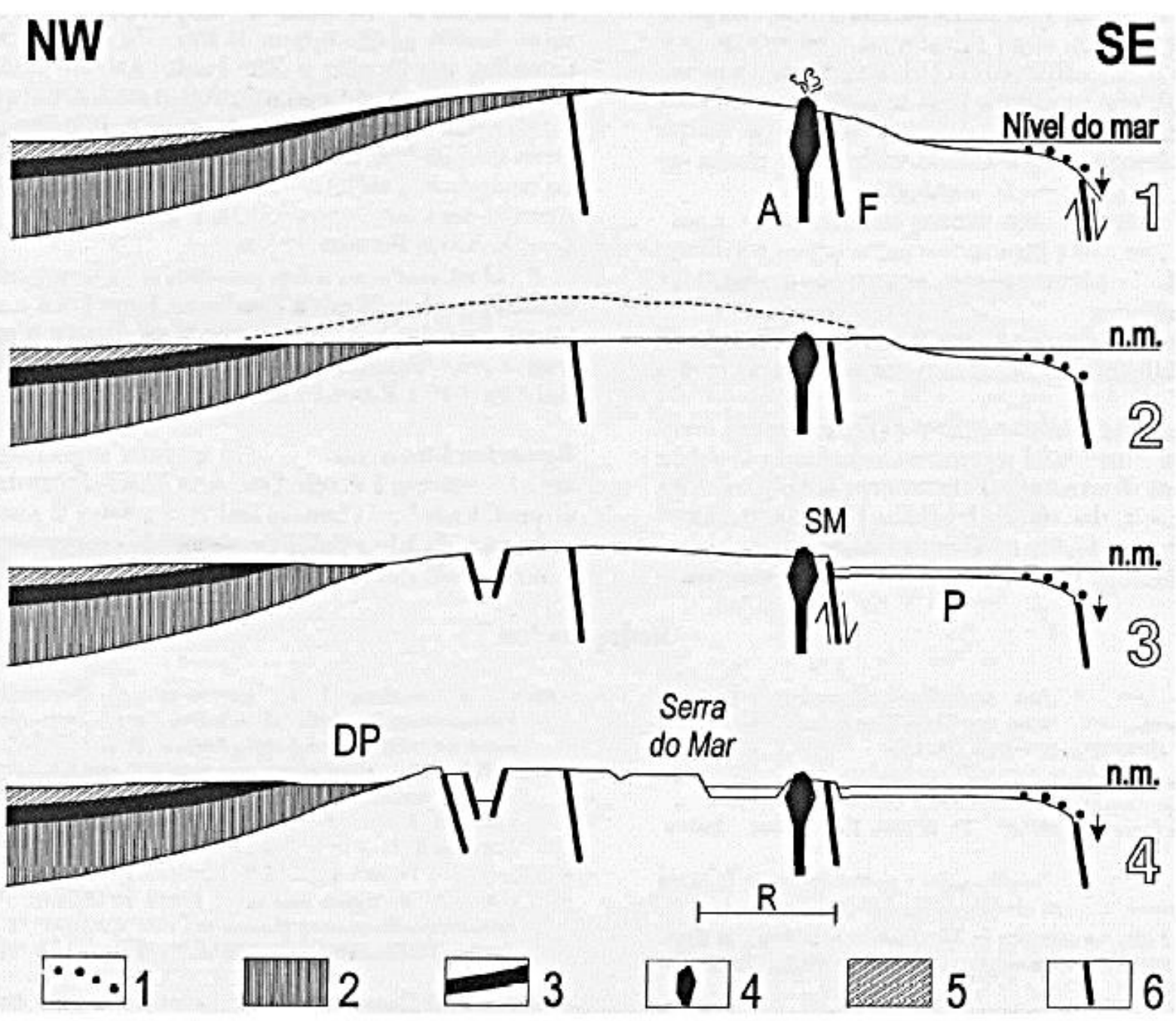

Figura 19 - Ilustração esquemática da origem e do recuo erosivo da escarpa da Serra do Mar, conforme interpretação de Almeida e Carneiro (1998). Estágios: 1. Soerguimento no Cretáceo trabalho erosivo em consequência, acompanhado de deposição nas bacias de Santos e do Paraná. Vulcanismo de natureza alcalina (A); Falha de Santos (F). 2. Desenvolvimento da Superfície Japi no Cretáceo. 3. Deformação da Superfície Japi no Paleoceno. Surgimento da Serra do Mar (SM) ao longo da Falha de Santos (F). Desenvolvimento da plataforma continental (P). 4. Recuo erosivo da Serra do Mar para sua posição atual (R). Depressão Periférica (DP). Convenções: 1. Depósitos da Formação Santos. 2. Cobertura fanerozóica sotoposta ao basalto Serra Geral. 3. Formação Serra Geral. 4. Corpos alcalinos. 5. Grupo Bauru. 6. Falhas. Fonte: Almeida e Carneiro (1998) 
O recuo da escarpa rumo ao interior do continente deve-se à combinação de processos fluviais, marítimos e a movimentos de massa (RIBEIRO, 2003), em superfícies fortemente declivosas e expostas a altos índices de precipitação (SANTOS, 2012). À medida que o recuo se processa, morros testemunhos e ilhas próximas à costa, correspondentes a núcleos rochosos mais resistentes, são destacados da Serra do Mar. 


\section{RESULTADOS E DISCUSSÃO}

\subsection{OBSERVAÇÕES GERAIS A RESPEITO DO RELEVO NA REGIÃO DE COLÔNIA}

Apresenta-se uma descrição detalhada da morfologia da área, com base nos seguintes produtos cartográficos, obtidos a partir de fotointerpretação e análise de MDEs: carta morfológica (Anexo 1); carta hipsométrica sobreposta ao modelo sombreado (Mapa 8); conjunto de cartas hipsométricas de níveis selecionados, constituindo um "fatiamento do relevo" (Mapa 9); carta clinográfica (Mapa 10); carta de rupturas de declividades (Mapa 11); carta de orientações do relevo (Mapa 12); carta de delimitação de aneis concêntricos (Mapa 13); perfis topográficos (Figura 20) e mensurações morfométricas.

Dividiu-se a área em 11 compartimentos geomorfológicos, com base em critérios morfológicos (padrões de formas, níveis altimétricos, clinografia e orientações preferenciais das formas do relevo) e geológicos (embasamento cristalino ou sedimentar). A divisão é apresentada conforme a numeração presente no Mapa 8.

- Cratera de Colônia: 1) Depressão Central; 2) Anel Colinoso;

- Colinas e Morros da Zona de Formas Concêntricas à Cratera: 3) Setor Setentrional; 4) Setor Ocidental; 5) Setor Meridional; 6) Setor Oriental;

- Compartimentos externos à Zona de Formas Concêntricas: 7) Colinas de Embura; 8) Planície do Ribeirão Embura; 9) Colinas e Morros da Bacia do Rio Capivari; 10) Colinas e Morros da Bacia do Rio Jurubatuba; 11) Colinas e Morros da Bacia do Rio Embu-Guaçu.

\subsubsection{Cratera de Colônia}

A cratera de Colônia é dividida em dois compartimentos: a Depressão Central, plana e esculpida em sedimentos quaternários, e o Anel Colinoso, dissecado e esculpido em rochas cristalinas do embasamento pré-cambriano e em unidades sedimentares terciárias isoladas. 
Mapa 8. COLÔNIA - SÃO PAULO, SP

\section{Carta hipsométrica sobreposta ao modelo sombreado}

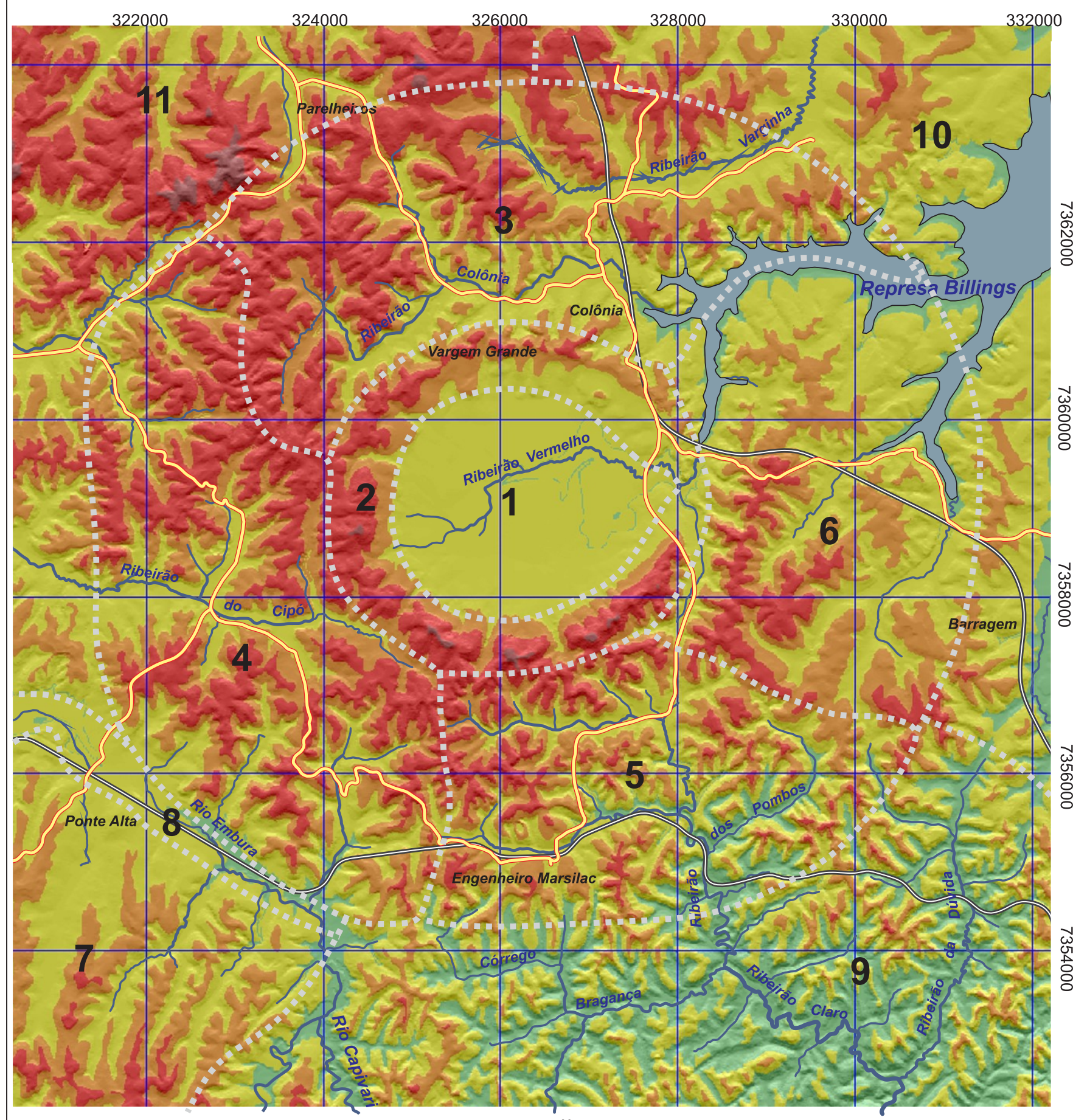

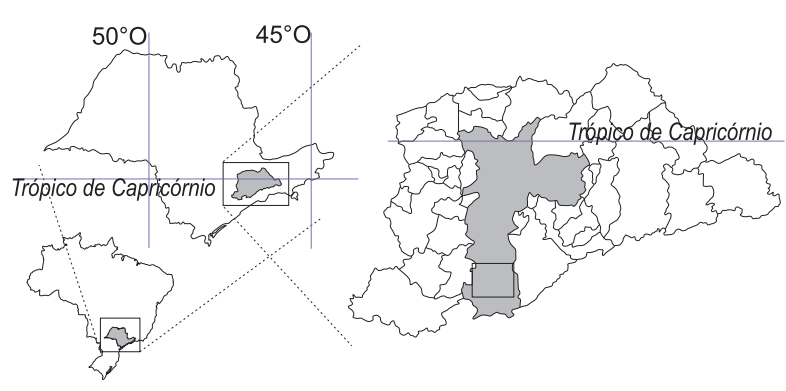

FONTE

- EMPLASA: Mapa topográfico - São Paulo-SP: Região Metropolitana. Escala 1:10.000, 1980.

- IS/Várias Empresas: Levantamento aerofotogramétrico «Estado de São Paulo»: Escala 1:25.000, 1962.

Elaborado por Santos, 2013
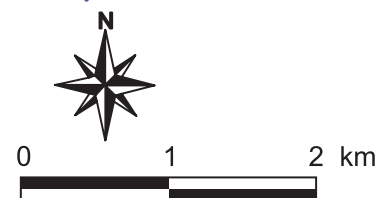

Elementos planimétricos

Corpos d'água

Cursos d'água

$\rightleftharpoons$ Estradas

$=$ Ferrovias

Sistema de coordenadas UTM Fuso $23 \mathrm{~K}$
Limites entre as unidades geomorfológicas

Altitudes (m)

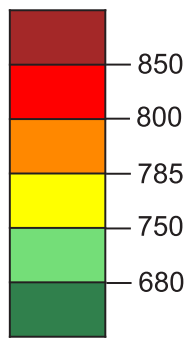

(cores levemente modificadas devido à sobreposição ao modelo sombreado) 

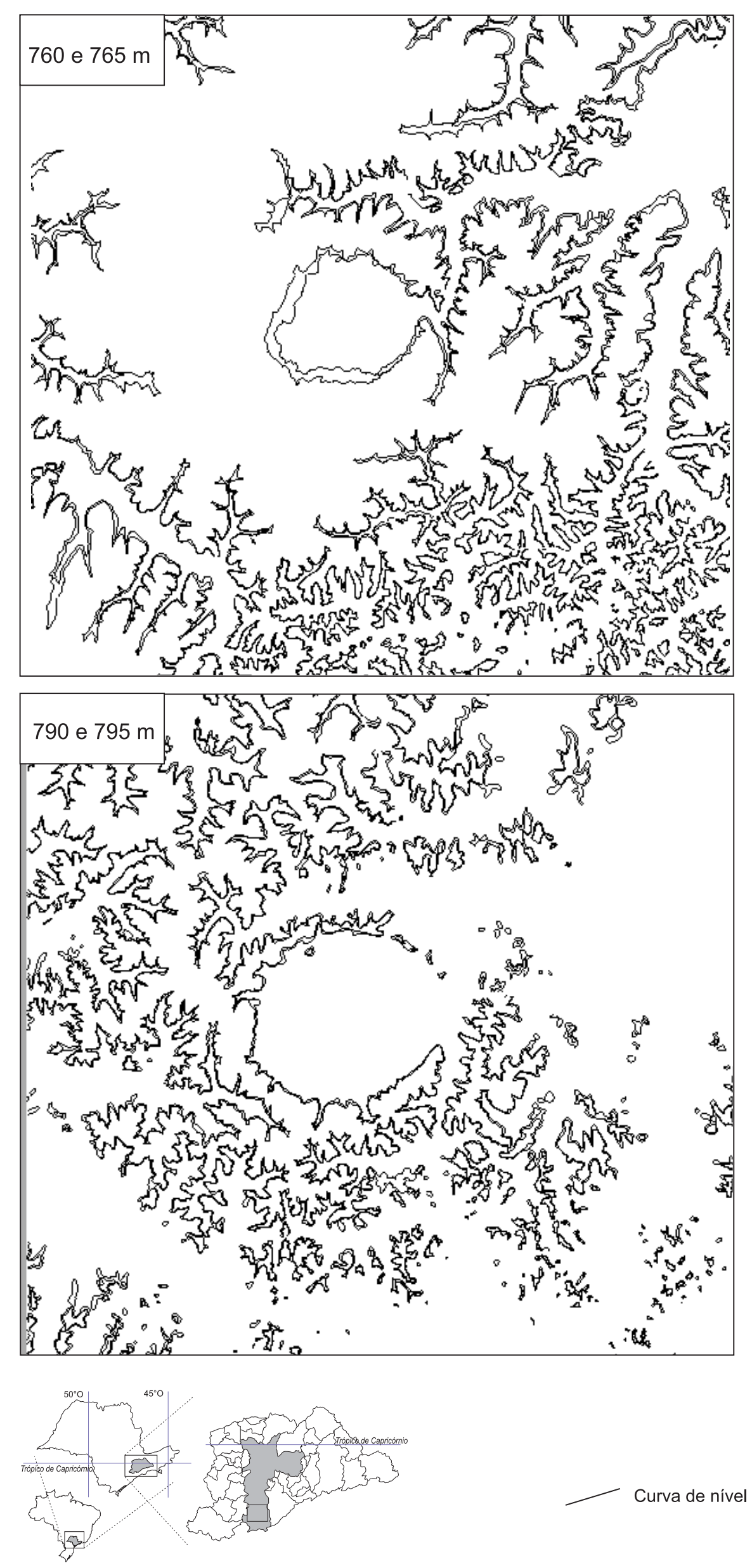

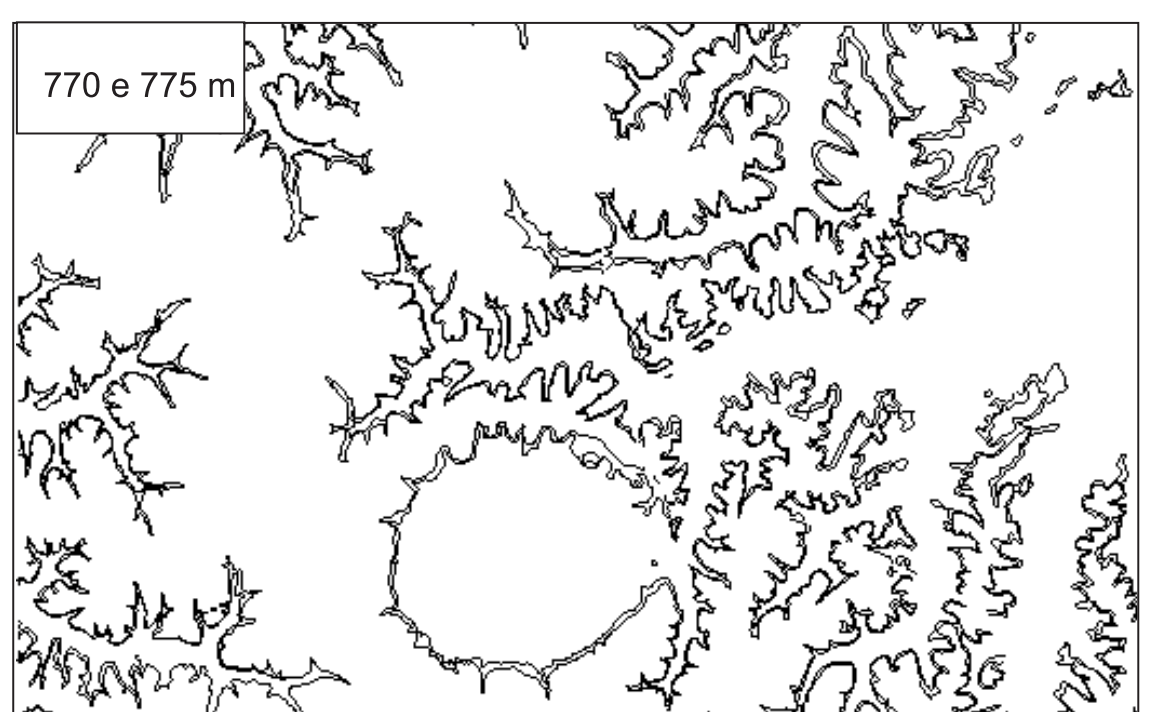

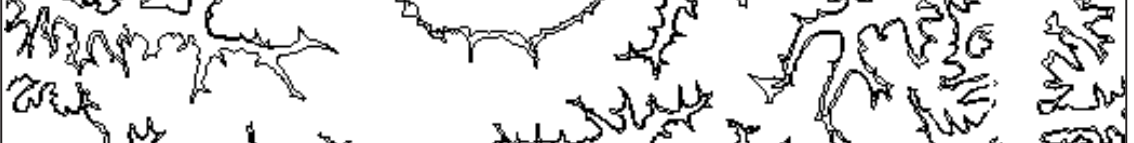

$\therefore$ है

130 br 4035

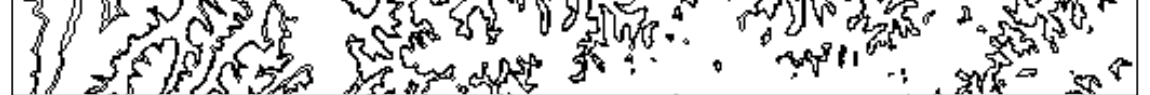

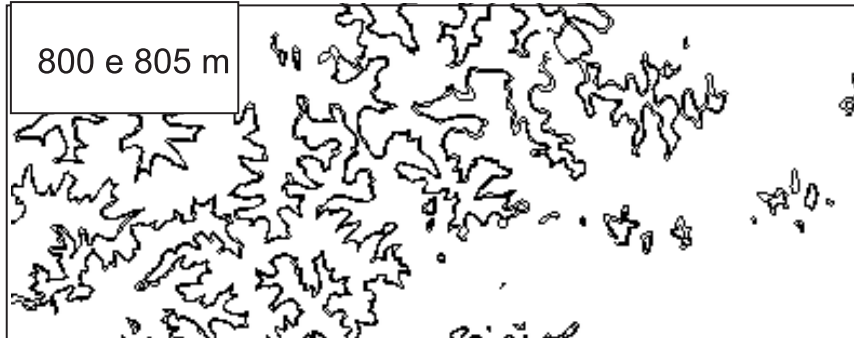

a

की

(n)

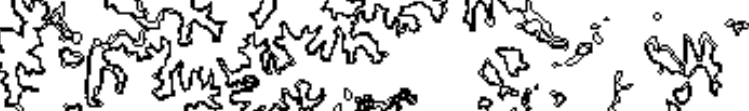

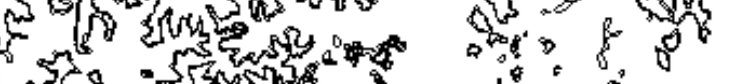

年

$s^{\infty} 0^{i}$

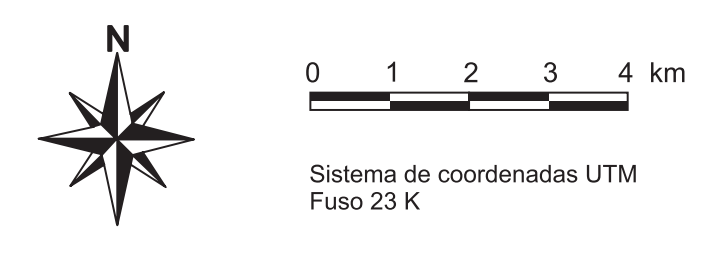

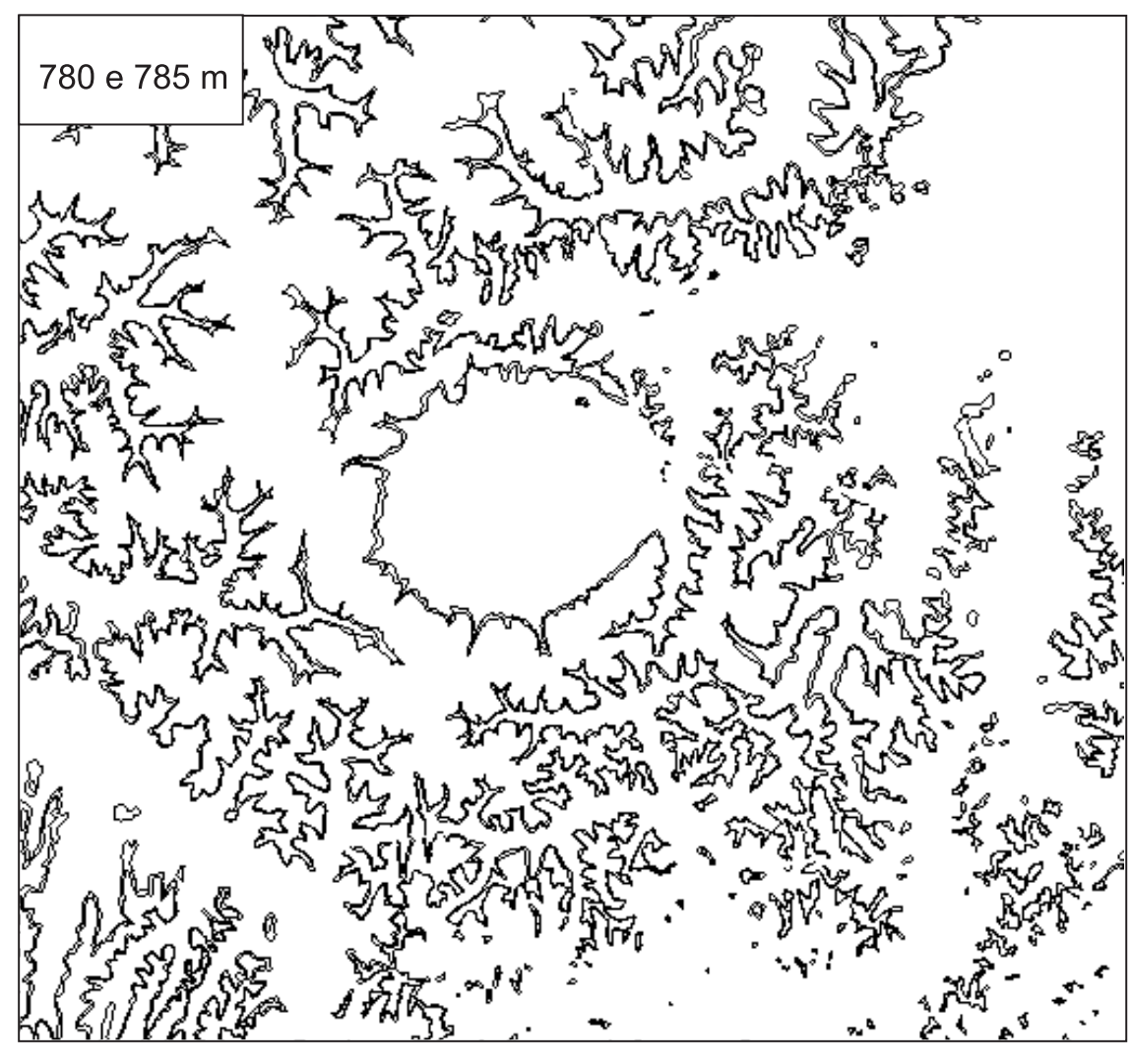

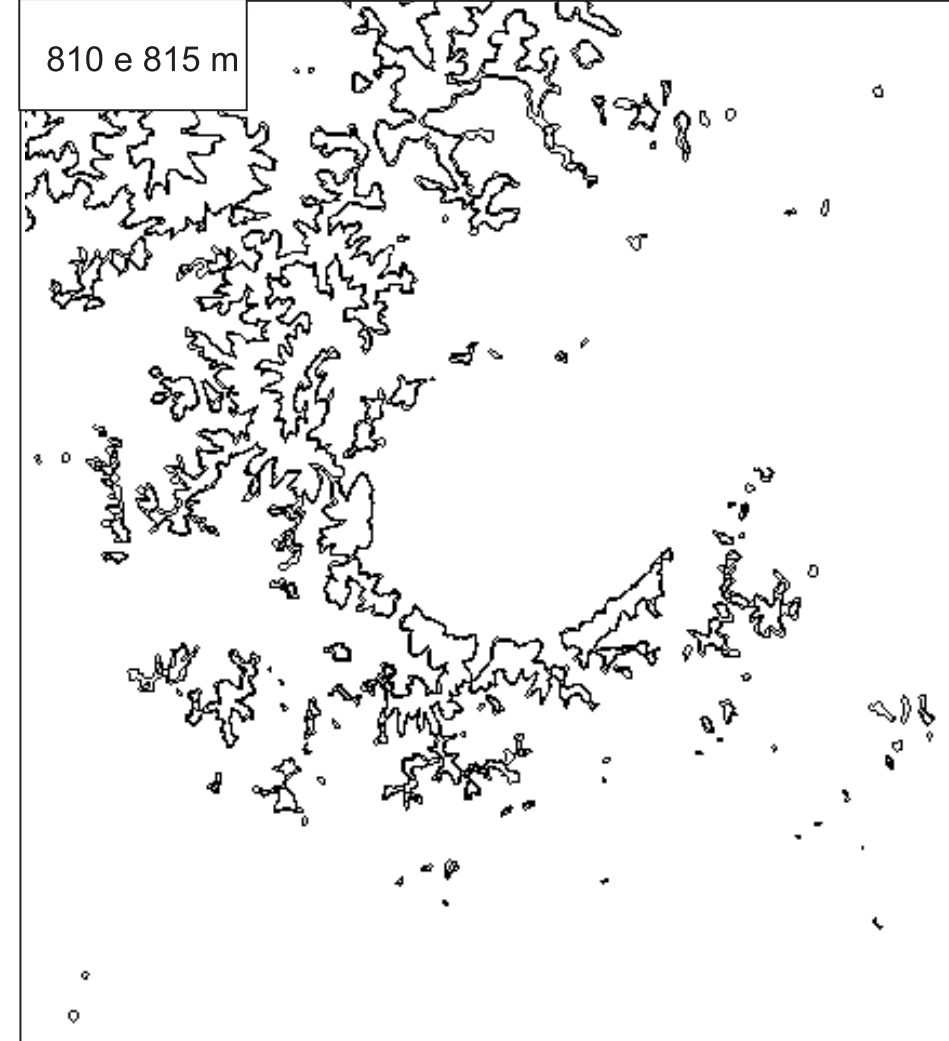

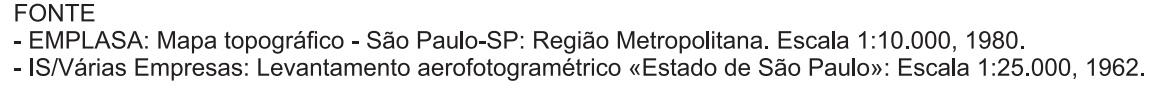




\section{Mapa 10. COLÔNIA - SÃO PAULO, SP Carta clinográfica}

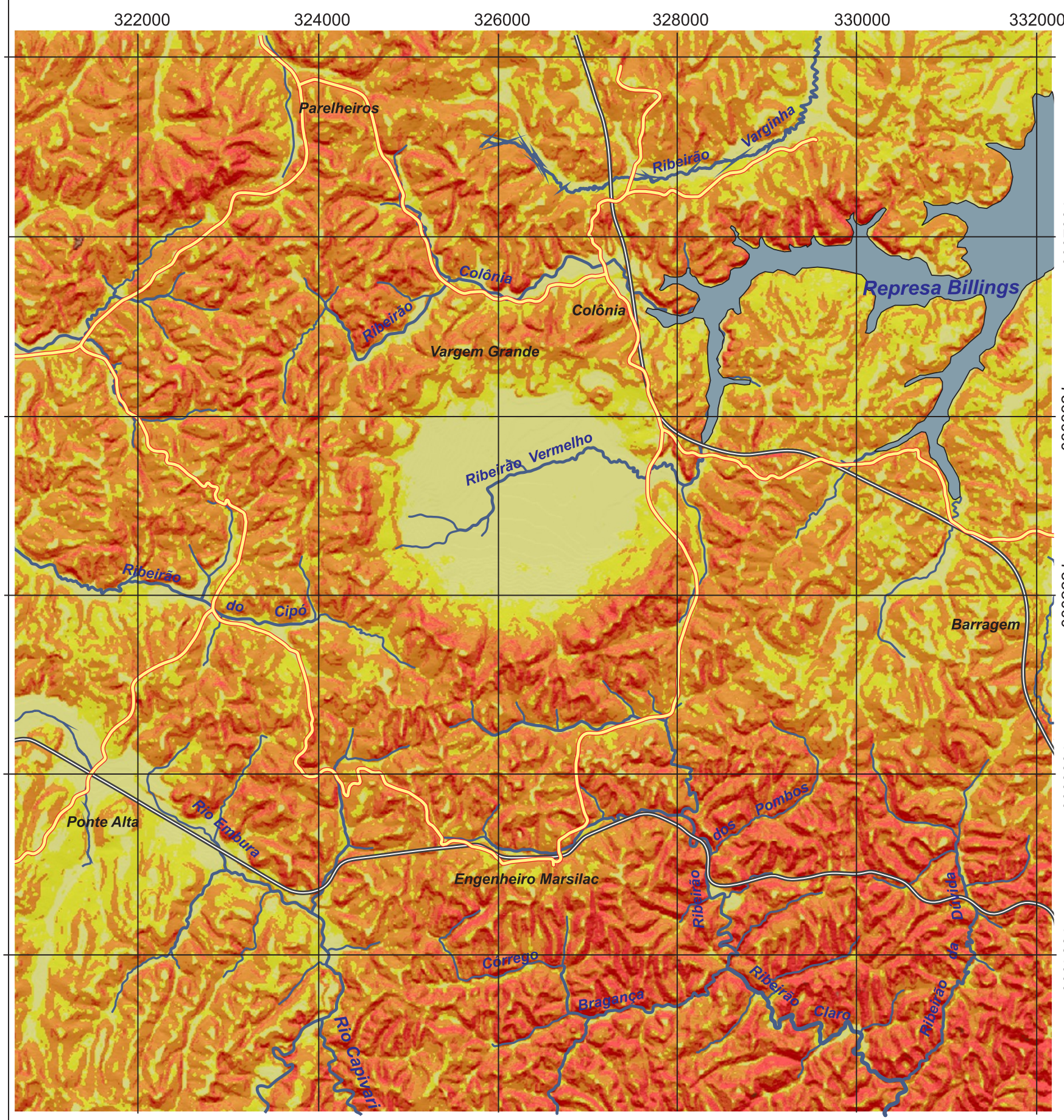

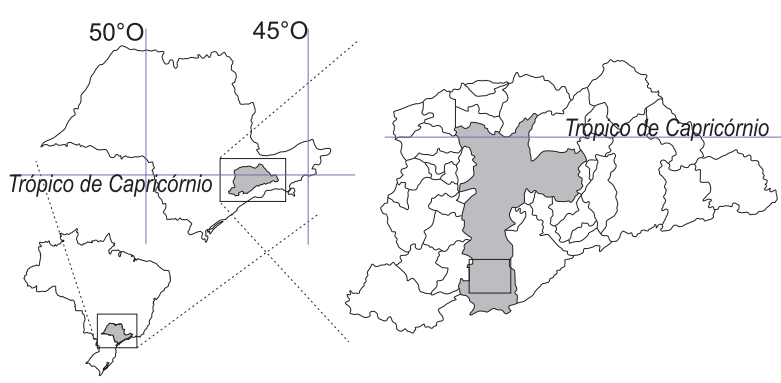

FONTE

- EMPLASA: Mapa topográfico - São Paulo-SP: Região Metropolitana Escala 1:10.000, 1980

- IS/Várias Empresas: Levantamento aerofotogramétrico «Estado de São Paulo»: Escala 1:25.000, 1962.

Elaborado por Santos, 2013.

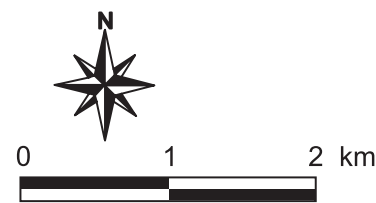

Elementos planimétricos

Corpos d'água

Cursos d'água

Estradas

$=$ Ferrovias

Sistema de coordenadas UTM Fuso $23 \mathrm{~K}$
Declividades (\%)

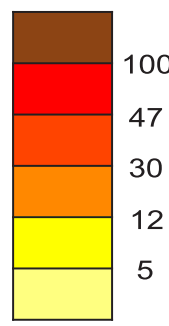

(cores levemente modificadas devido à sobreposição ao modelo sombreado) Classes de declividade conforme DeBiasi (1977) 

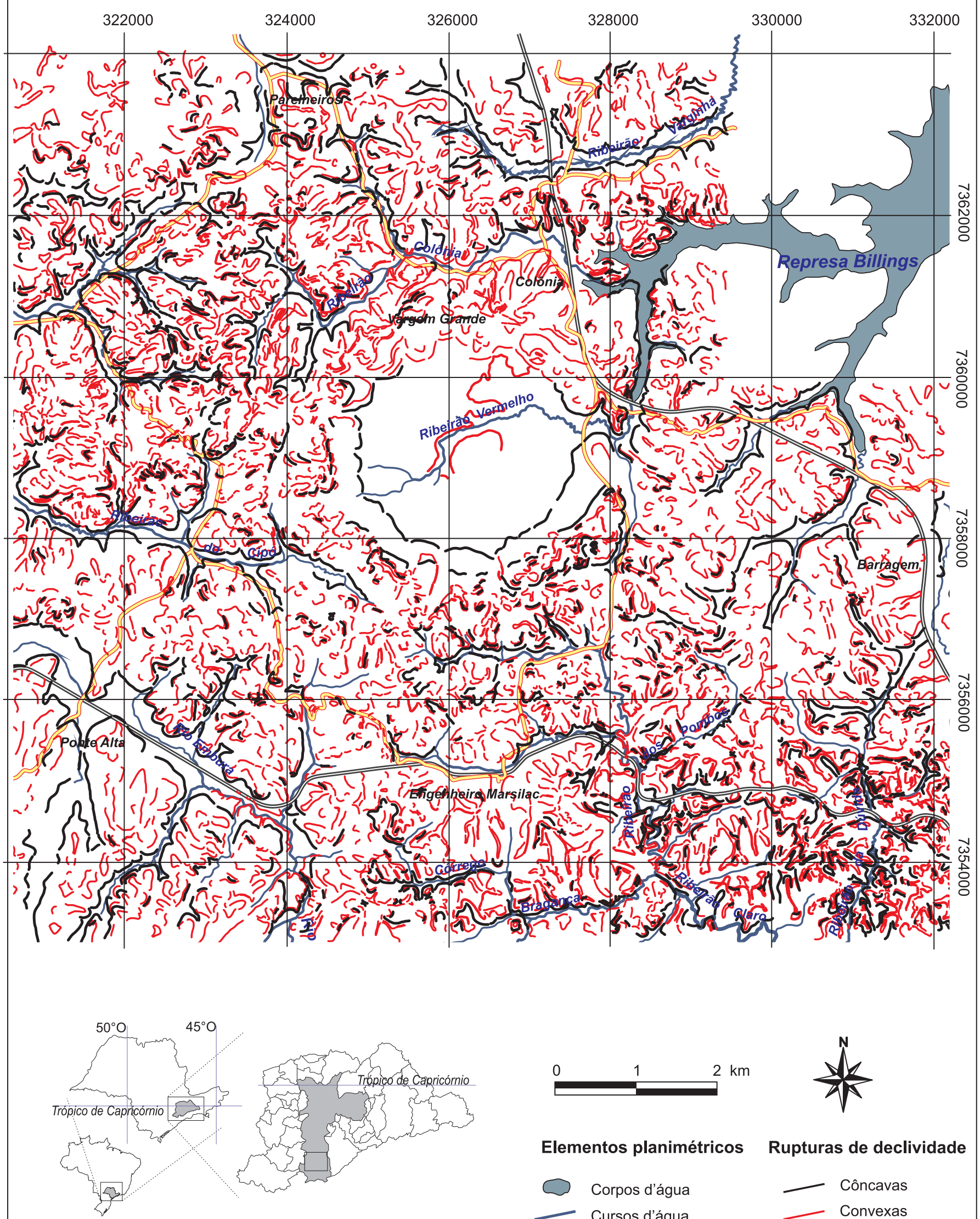

FONTE

- EMPLASA: Mapa topográfico - São Paulo-SP: Região Metropolitana. Escala 1:10.000, 1980.

- IS/Várias Empresas: Levantamento aerofotogramétrico «Estado de São Paulo»: Escala 1:25.000, 1962.

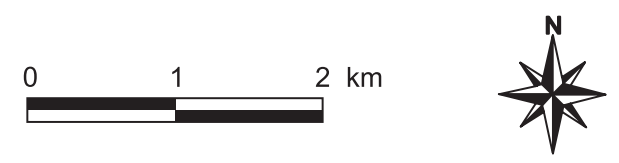

Elementos planimétricos Rupturas de declividade

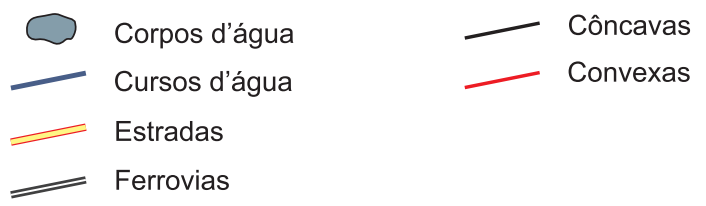


Mapa 12. COLÔNIA - SÃO PAULO, SP

Carta de orientações de vertentes
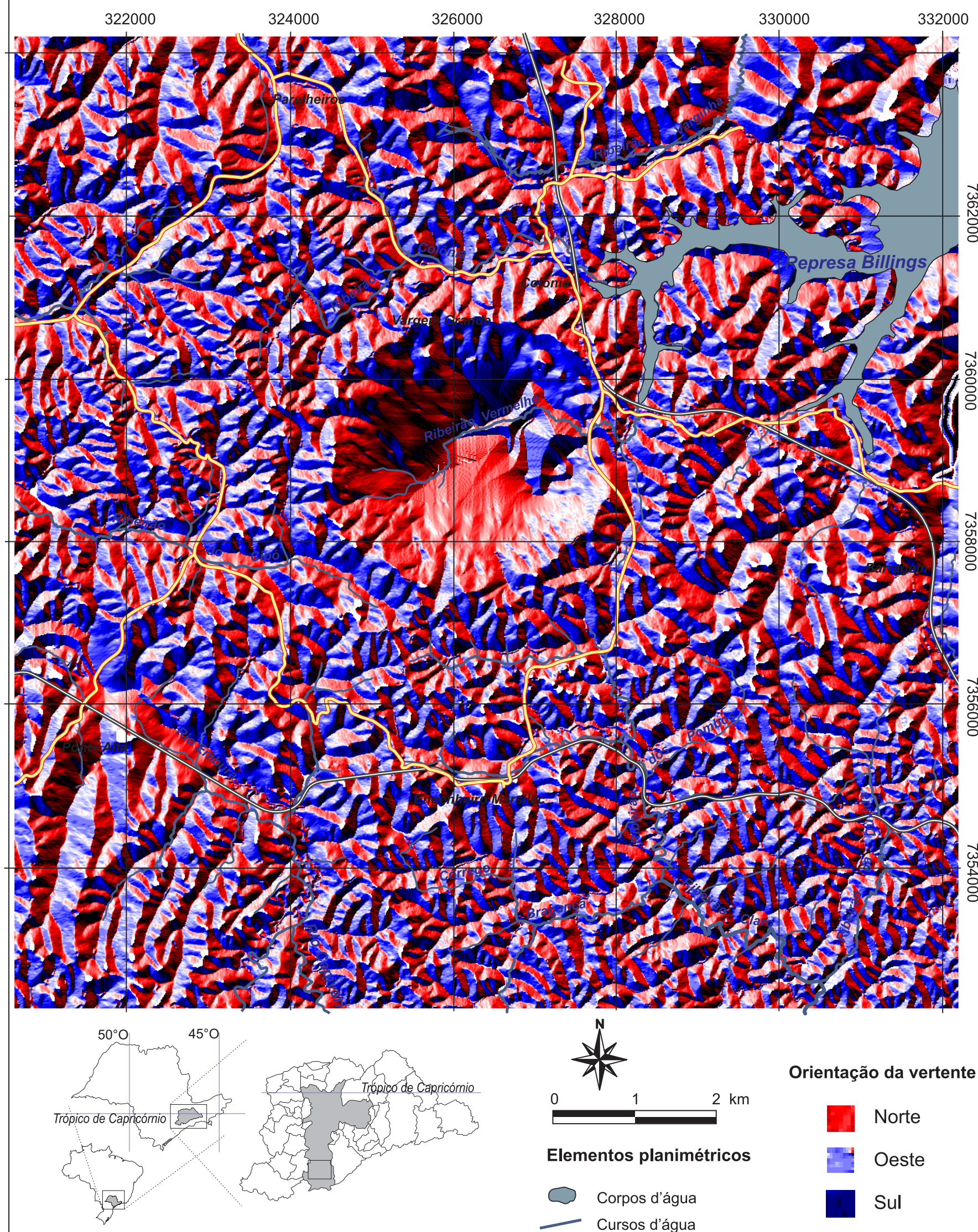

FONTE

- EMPLASA: Mapa topográfico - São Paulo-SP: Região Metropolitana.

Escala 1:10.000, 1980.

São Paulo»: Escala 1:25.000, 1962.

Elaborado por Santos, 2013

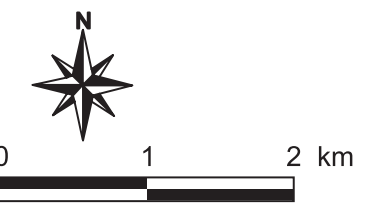

Elementos planimétricos

$\bigcirc$ Corpos d'água

Cursos d'água

Estradas

Ferrovias

Sistema de coordenadas UTM Fuso $23 \mathrm{~K}$
Orientação da vertente

Norte

Oeste

Sul

Leste 


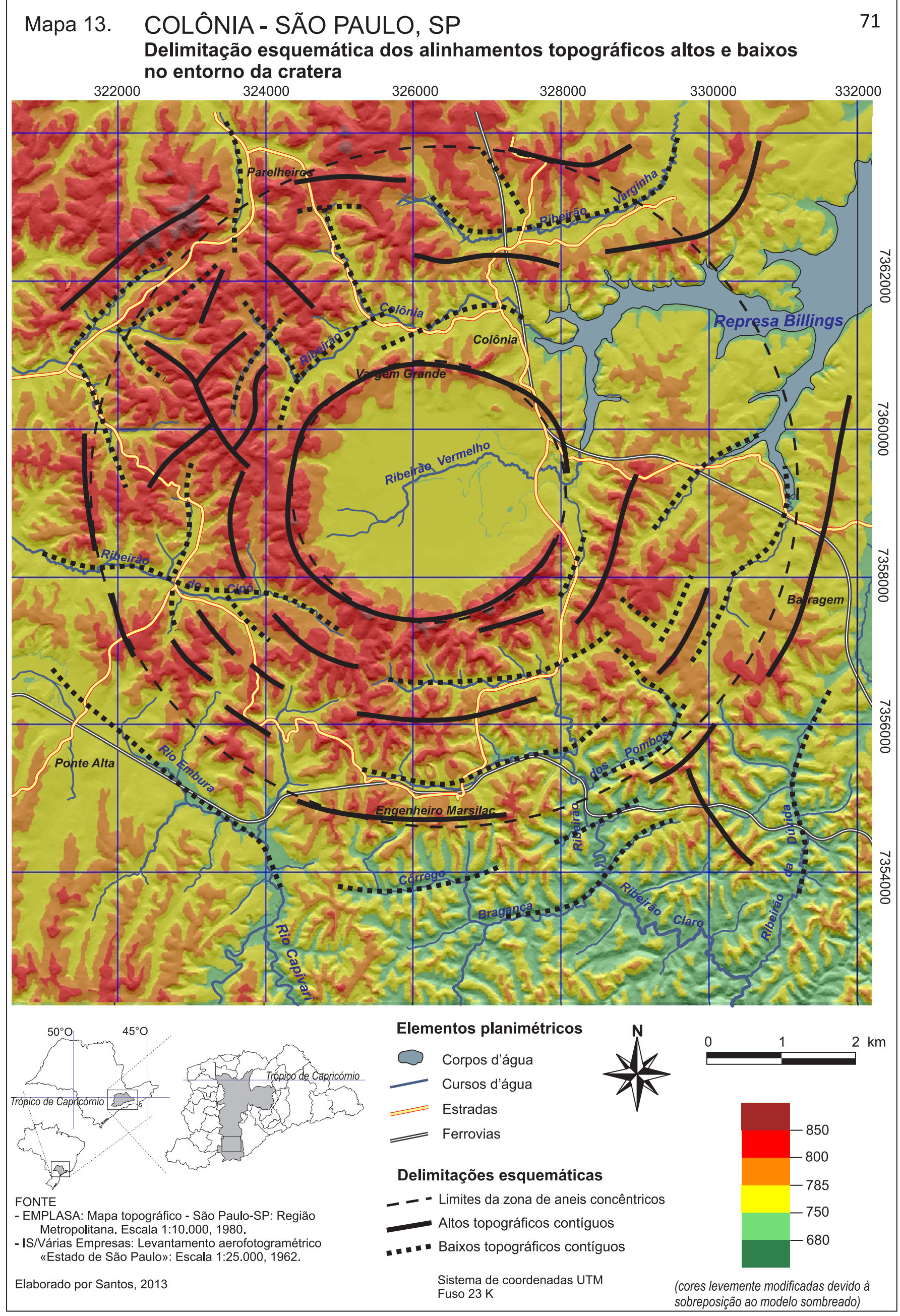



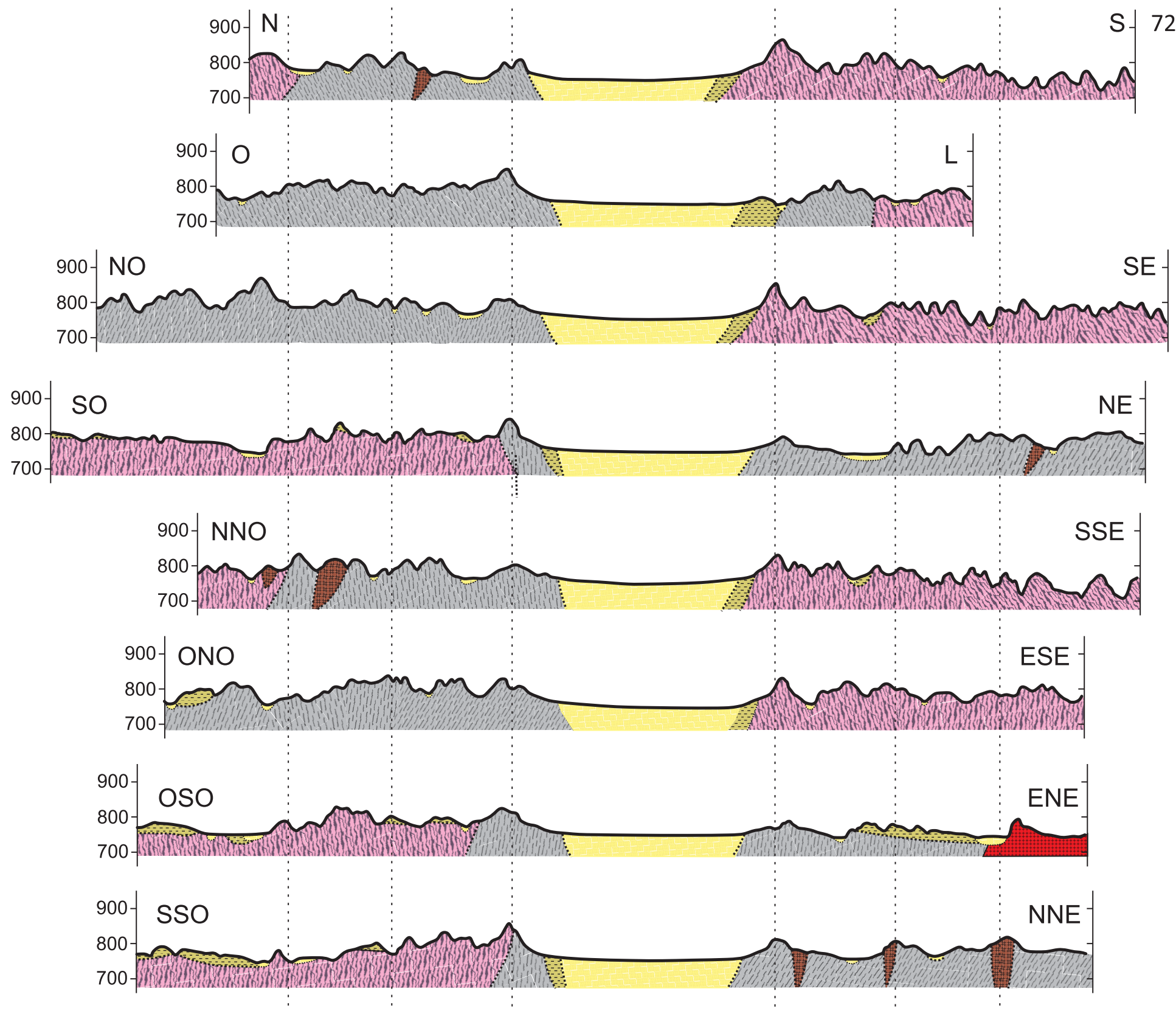

\begin{tabular}{llllllll|l|l|l|l}
\hline 0 & 1200 & 2400 & 3600 & 4800 & 6000 & 7200 & 8400 & 9600 & 10800 & 12000 & $\mathrm{~m}$
\end{tabular}

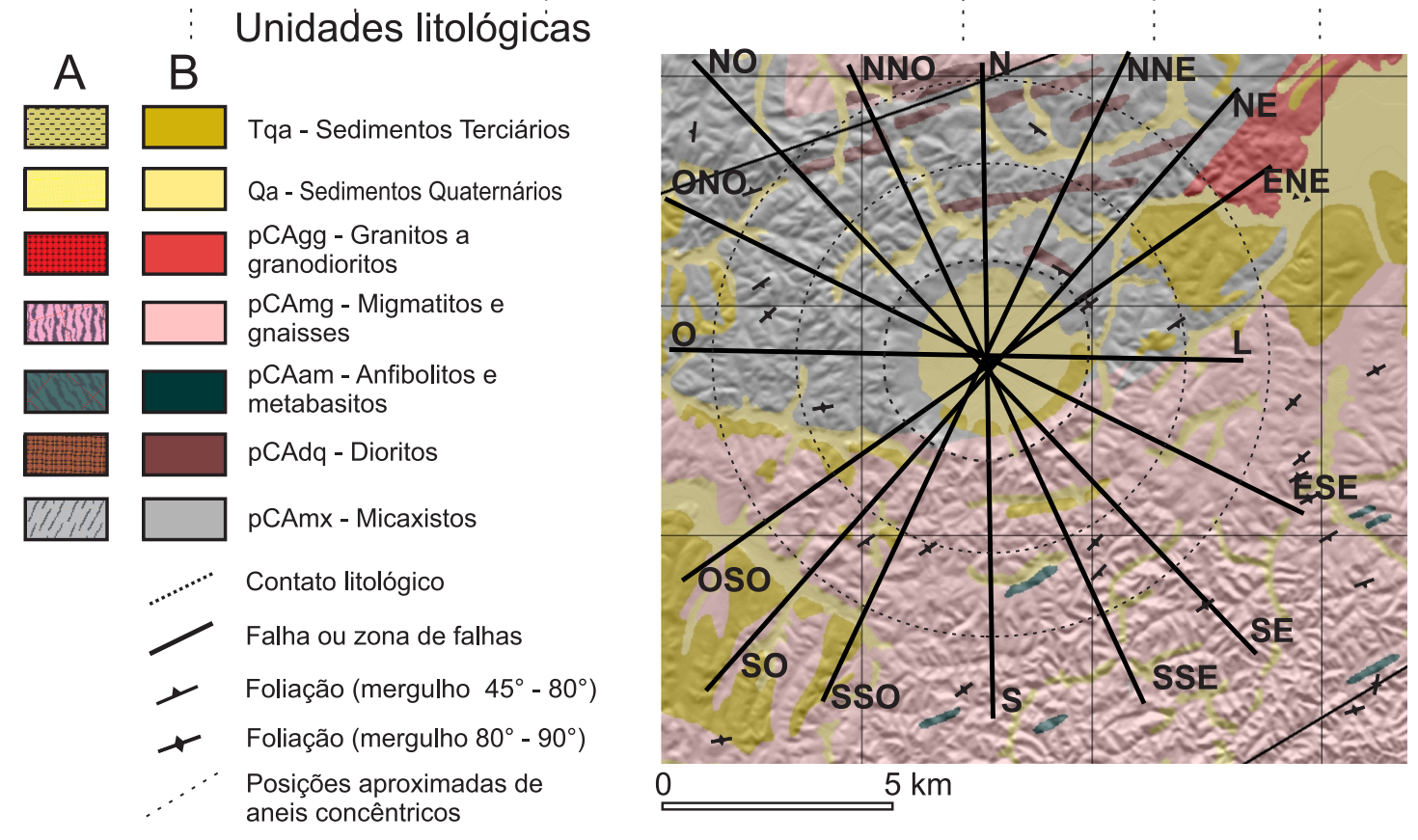

Figura 20 - Perfis geológicos radiais à cratera de Colônia. Elaborado por Santos, 2013. 
A Depressão Central da Cratera de Colônia é aproximadamente elíptica, mais alongada a leste-nordeste $(2.860 \mathrm{~m})$ que a sul-sudeste $(2.620 \mathrm{~m})$. O contato da depressão central com o anel colinoso é irregular, com entalhamentos produzidos por canais fluviais e pequenos lobos atribuídos a fluxos gravitacionais ocorridos a partir das paredes internas do anel.

A unidade constitui-se de terrenos planos (Foto 1) gerados por processos de agradação quando do preenchimento da depressão central da cratera por sedimentos de origem predominantemente lacustre (LEDRU et al., 2005). Os níveis altimétricos, de 750 a 755 m na área central, aumentam gradativamente para até $765 \mathrm{~m}$, no contato com o anel colinoso. As declividades predominantes são inferiores a 5\%, atingindo $10 \%$ nas rampas periféricas.

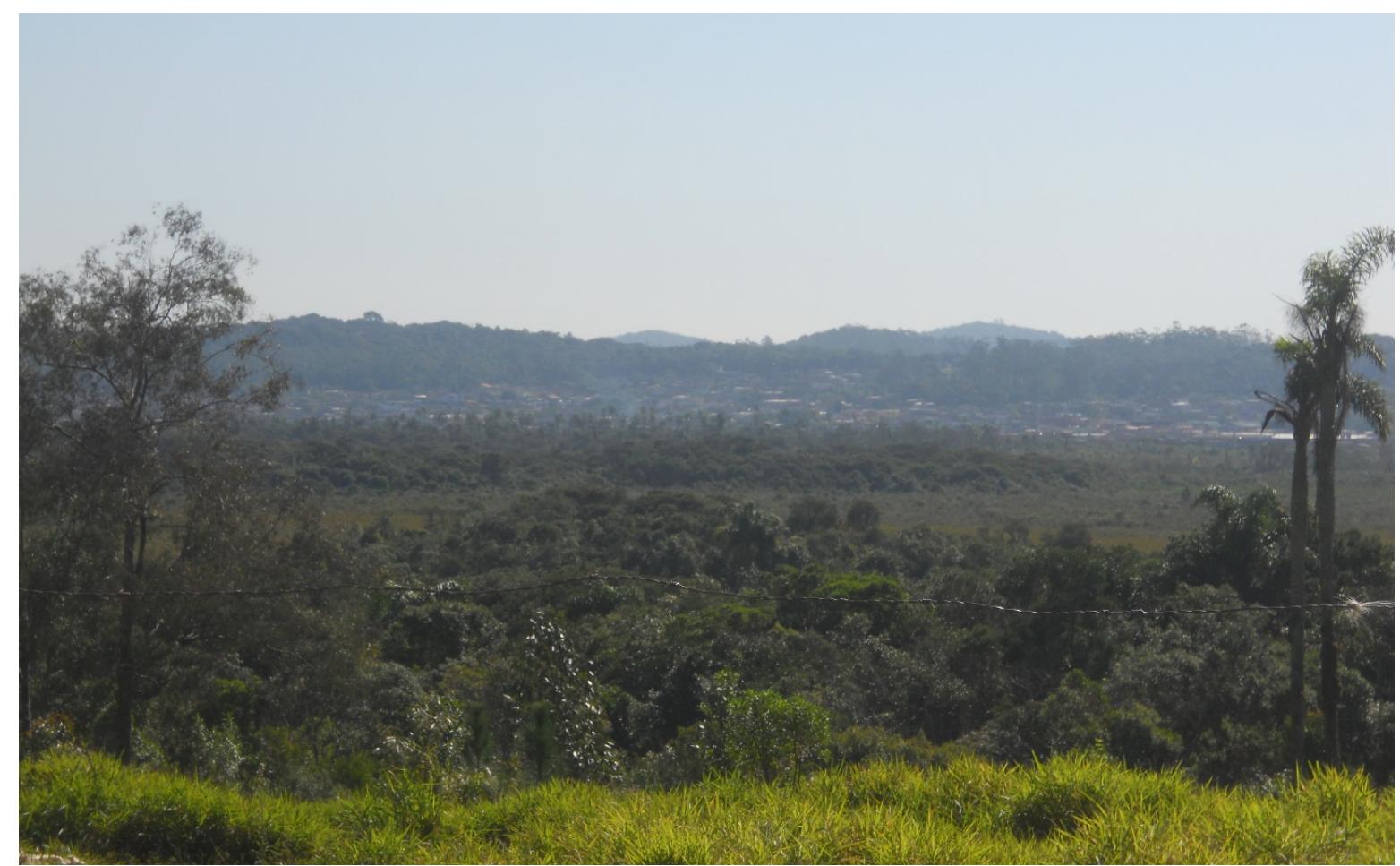

Foto 1 - Interior da cratera de Colônia, visto a partir da borda meridional. No primeiro plano, terrenos planos esculpidos em sedimentos quaternários de origem predominantemente fluvial, recobertos por uma vegetação de ambiente saturado em água, devido à dificuldade da drenagem na área. Ao fundo, vista do segmento setentrional do anel colinoso, parcialmente ocupado por edificações residenciais. Obtida por Santos, 2012. 
A depressão é atravessada pelo ribeirão Vermelho e em suas margens observam-se terraços fluviais que se erguem a menos de $5 \mathrm{~m}$ em relação ao curso d'água, tornando-os imperceptíveis no MDE e nos produtos derivados. Desta maneira, eles são identificáveis apenas em fotografias aéreas, tendo sido delimitados a partir da análise desses documentos. Sua presença relaciona-se à abertura da drenagem do interior da cratera, conforme discutido na seção 5.3.

O Anel Colinoso da Cratera de Colônia constitui-se de formas de relevo denudacionais cujo modelado consiste de colinas alongadas com topos convexos, dispostas em um arranjo elíptico que circunda a depressão central. A elipse que melhor se ajusta aos topos do Anel apresenta eixo maior (a) com 3.678 m, eixo menor (b) com $3.555 \mathrm{~m}$ de comprimento e razão a/b igual a 1,035. A elipse se alonga na direção leste-oeste e seu centro situa-se nas coordenadas UTM: $326.155 \mathrm{mE}$, 7.359.097 mN da Zona 23K.

Predominam unidades litológicas do embasamento pré-cambriano: há micaxistos em praticamente toda a extensão do Anel e unidades gnáissicas a sul. Estas últimas encontram-se parcialmente recobertas por unidades sedimentares terciárias. Não há, conforme a carta geológica (Mapa 2), quaisquer unidades ígneas sustentando o anel colinoso. Em campo, também não se identificaram unidades ígneas.

Seu relevo encontra-se fragmentado, com diversos cumes isolados (Foto 2). Essa fragmentação deve-se ao entalhe produzido por canais fluviais, alguns deles com nascentes no exterior da linha formada pelos topos do anel. Os canais produziram rebaixamentos na crista anelar de até $50 \mathrm{~m}$ a sul, $70 \mathrm{~m}$ a oeste e $30 \mathrm{~m}$ a norte, em relação à linha de cumeada. A leste, o entalhamento atingiu o nível da Depressão Central da Cratera de Colônia e aí se estabeleceu o exutório da bacia do ribeirão Vermelho. Predominam vales em "V", mas também há vales em berço, os últimos a noroeste e a sul. Os primeiros são mais frequentes em locais de maior expressão dos lobos e os últimos em terrenos sedimentares do Terciário.

As dimensões interfluviais são de 190 a $750 \mathrm{~m}$ na parede interna do anel colinoso. Na parte externa, os valores são menores, de 90 a $560 \mathrm{~m}$. No setor meridional da parede interna, há uma extensão de $1460 \mathrm{~m}$ na qual os canais fluviais são ausentes, coincidente com a presença de sedimentos terciários. 
Os níveis dos cumes do Anel variam conforme o azimute a partir do ponto central. A norte, os níveis dos cumes são de 790 e 815 m; a oeste, de 825 a 850 m; a sul, de 835 a 860 m; a leste, de 780 a 840 m. É evidente sua assimetria altimétrica, com cumes mais elevados a sul e oeste que a norte e leste, concordante com a assimetria altimétrica dos terrenos em seu entorno imediato, também mais elevados a oeste que a leste.

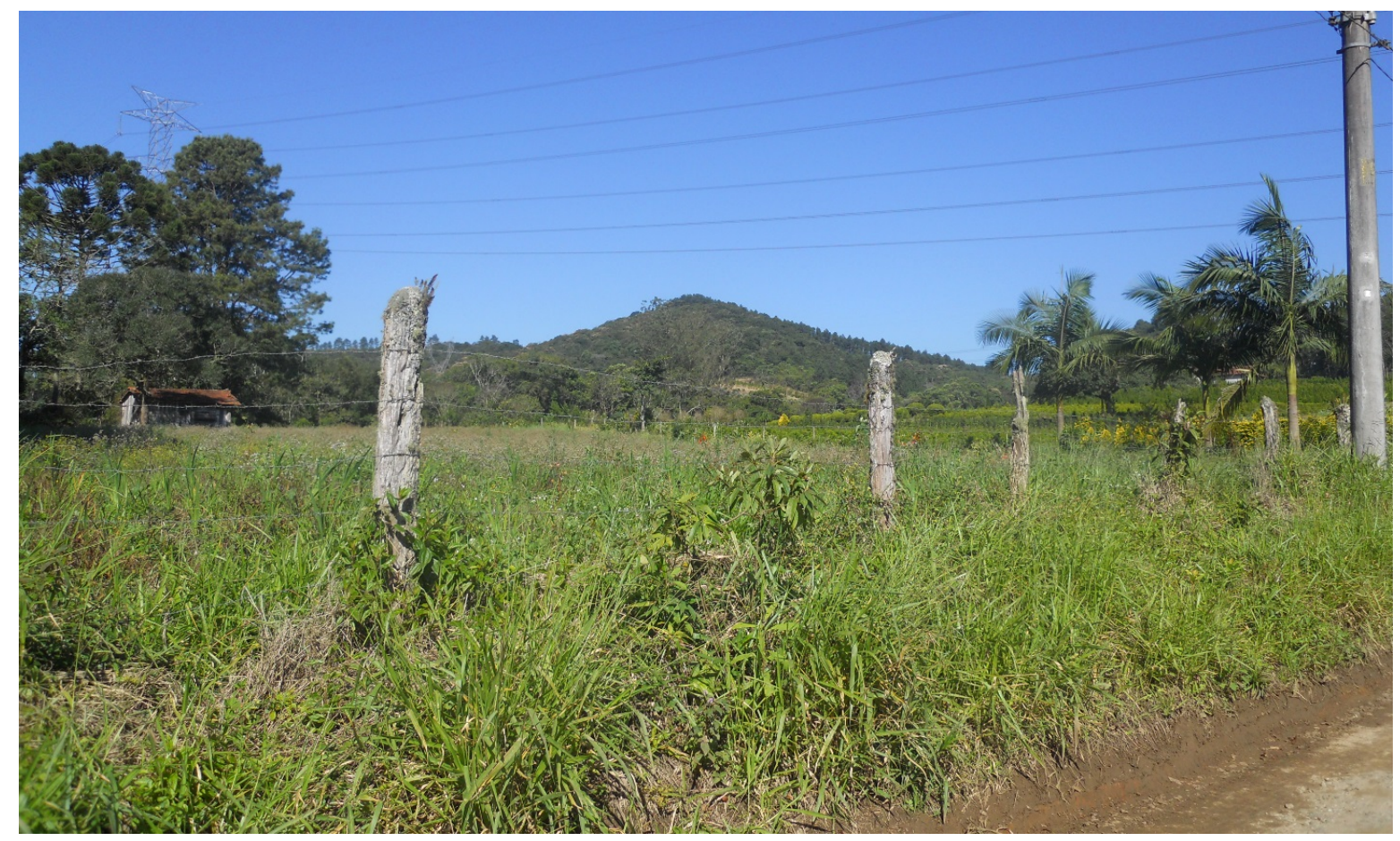

Foto 2 - Fragmento do anel colinoso, na borda meridional da cratera de Colônia. O anel foi fragmentada pela atividade fluvial, que produziu colos de até $70 \mathrm{~m}$ de profundidade em relação à sua linha de cumeada. Obtida por Santos, 2012.

Predominam, ao longo do Anel, declividades de 25 a 35\%. Os valores são maiores na face interna que na externa, conforme esperado para crateras de impacto (MELOSH, 1989), com exceção do segmento norte, onde os lobos relacionáveis a fluxos gravitacionais são mais desenvolvidos e ampliam lateralmente a extensão do anel colinoso. Nas frentes dos lobos, perfazendo o contato com a Depressão Central, registram-se rampas com mais de $40 \%$ de declividade. 
No exutório da bacia do ribeirão Vermelho, o anel colinoso é interrompido abruptamente por uma garganta ladeada por vertentes de 50 a $80 \%$ de declividade a norte e de 8 a $40 \%$ a sul.

O padrão de drenagem no interior da cratera de Colônia, incluindo as duas unidades descritas, é radial centrípeto, com a maioria dos canais convergindo para sua área central, seguindo para leste. A baixa densidade de canais e seu padrão radial centrípeto tornam a unidade marcadamente diferente do entorno. A origem de sua rede de drenagem será discutida na seção 5.4 .

\subsubsection{Colinas e Morros da Zona de Formas Concêntricas à Cratera de Colônia}

Partindo de observações a respeito do modelado do relevo e da configuração das redes de drenagem, é possível discernir, no entorno da cratera de Colônia, uma zona de aproximadamente $2.500 \mathrm{~m}$ de largura que apresenta formas orientadas radial e paralelamente à cratera de impacto. Longe de serem conspícuas, essas formas ocorrem em meio a outras, de direções variadas, produzindo uma topografia "camuflada", pouco visível sem um tratamento cartográfico que a exiba mais claramente.

As colinas e os morros do entorno da cratera de Colônia são agrupados em quatro setores: setentrional, ocidental, meridional e oriental, não correspondendo exatamente aos pontos cardeais, mas a regiões de formas homogêneas. A finalidade da subdivisão é comparar o desenvolvimento do relevo nos respectivos setores e correlacionar com a evolução geomorfológica do Planalto Paulistano.

A borda desse conjunto é de difícil delimitação: dada a característica pouco evidente da topografia concêntrica, o posicionamento do traço possui certo grau de arbitrariedade. A leste, há poucos remanescentes de cumes paralelos ao anel colinoso da cratera e torna-se difícil a seleção do que melhor representa o limite do conjunto de formas concêntricas. Selecionou-se o traçado que, delimitando vales e cristas orientados concentricamente, torna a elipse formada menos excêntrica. Já em outros trechos, como a oeste e sul, a delimitação é facilitada pela existência de cumes na faixa altimétrica de 800 a $810 \mathrm{~m}$, formando um alinhamento bem definido, paralelo ao anel colinoso. 
Os limites da zona de formas concêntricas se ajustam a uma elipse que possui eixo maior (a) com $8.950 \mathrm{~m}$ de comprimento e eixo menor (b) com $8.622 \mathrm{~m}$, apresentando razão a/b igual a 1,038. A elipse se alonga na direção leste-oeste e seu centro situa-se nas coordenadas UTM: 326.155 mE, 7.359.097 mN da Zona 23K, distando $54 \mathrm{~m}$ para sudoeste do centro da elipse ajustada ao anel colinoso da cratera. Com centros próximos e eixo maior na mesma direção, as duas elipses exibem bom ajustamento, apesar do certo grau de arbitrariedade na delimitação da última.

Segue-se a descrição individualizada da morfologia dos quatro setores da zona de formas concêntricas.

No Setor Setentrional da Zona de Formas Concêntricas à Cratera predominam formas de relevo denudacionais, com topos convexos (Foto 3). As litologias da maior parte da unidade compõem o embasamento pré-cambriano: são predominantes os micaxistos, localmente seccionados por pequenas unidades de dioritos, alongadas na direção leste-nordeste. Ao norte, a unidade de micaxistos é delimitada por uma falha, para além da qual ocorrem unidades de gnaisses. Já nos vales dos ribeirões Colônia e Varginha, ocorrem sedimentos fluviais de idade quaternária.

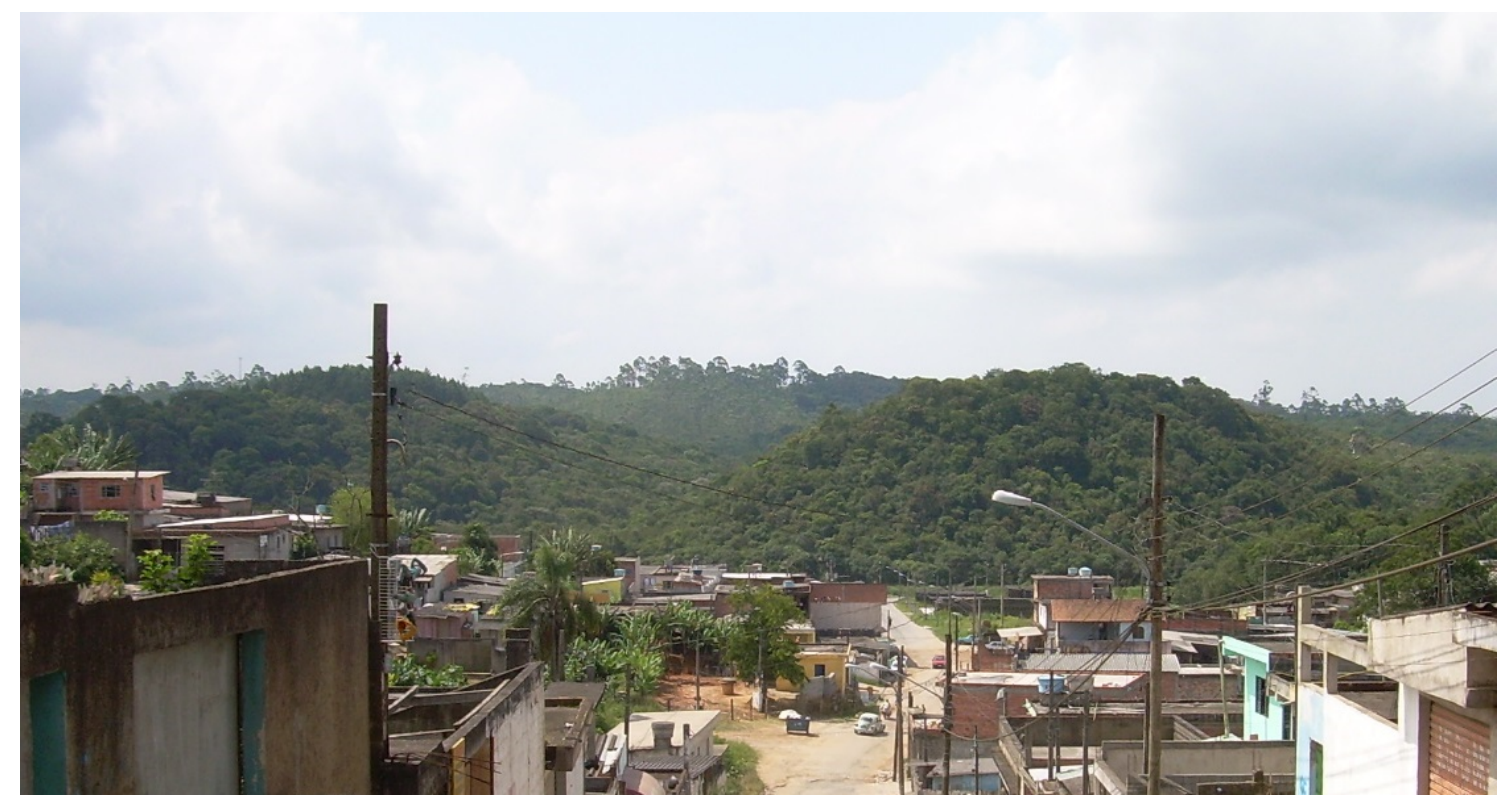

Foto 3 - Exterior da cratera de Colônia, visto a partir do segmento setentrional de seu anel colinoso. Notar relevo dissecado, constituído por morros com topos convexos, contrastando com o relevo plano do interior da cratera. Obtida por Santos, 2007. 
O entalhamento típico dos vales é de 40 a $50 \mathrm{~m}$ e as dimensões interfluviais predominantes são de 100 a 450 m. São comuns os vales em "V", em praticamente todas as ramificações dos vales dos rios principais. Há poucos vales em berço, acompanhando os principais canais fluviais, bem como vales dissimétricos, com vertentes mais íngremes orientadas para sul, nas proximidades da cratera.

Os níveis altimétricos dos cumes são maiores na sub-bacia do ribeirão Colônia (mais próximo à cratera) que na do ribeirão Varginha: 795 a 840 m no primeiro e 745 a $755 \mathrm{~m}$ no último. Os cumes desta unidade erguem-se a altitudes maiores que as do Anel Colinoso.

Observa-se dissimetria clinográfica nas vertentes da área. Enquanto as orientadas a norte possuem declividades de 15 a $20 \%$, naquelas voltadas para o sul variam de 40 a 50\%. As linhas divisórias entre vertentes dissimétricas são aproximadamente lineares, de direção leste-nordeste. A partir delas, projetam-se cumes estreitos alongados para sul-sudeste.

É notório o alinhamento do alto curso do ribeirão Colônia, ora radial (trecho de direção sul-sudeste), ora paralelamente (trechos de direção norte-nordeste) à borda da cratera de Colônia. Além disso, diversos outros canais próximos alinham-se paralelamente ao anel colinoso. No entanto, é necessária cautela na interpretação de sua origem, pois esses alinhamentos passam a divergir do padrão concêntrico mais a norte.

O Setor Ocidental da Zona de Formas Concêntricas à Cratera constitui-se de formas de relevo denudacionais, predominando colinas e morros de topos convexos (Foto 4). As litologias da maior parte da unidade compõem o embasamento précambriano: as principais unidades são os micaxistos a norte e gnaisses a sul, limitados pelo ribeirão Cipó, cujo vale apresenta sedimentos quaternários. Ocorrem também pequenos fragmentos de sedimentos terciários, distribuídos principalmente ao longo da margem esquerda do ribeirão Cipó. 


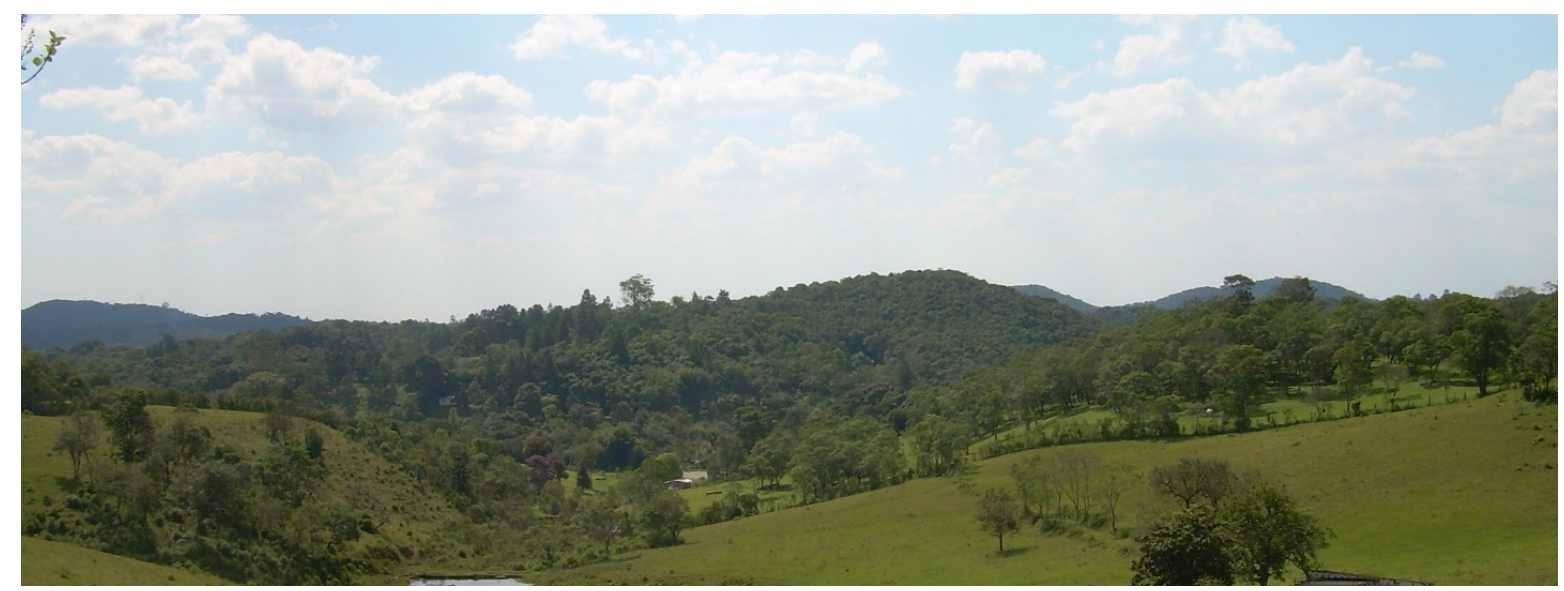

Foto 4 - Paisagem no Setor Ocidental da Zona de Formas Concêntricas à Cratera, exibindo forte dissecação, topos convexos e vales em "V", a partir da Estrada de Marsilac. Obtida por Santos, 2009.

O entalhamento dos vales é de 30 a $45 \mathrm{~m}$, à distância de até $1.500 \mathrm{~m}$ a partir da crista da cratera, passando a 40 a 55 m após desse limite. Predominam vales em "V" e ocorrem poucos vales em berço, nos altos cursos dos canais principais. As dimensões interfluviais são de 120 a 280 m na primeira faixa e de 90 a $220 \mathrm{~m}$ na última.

Os níveis dos cumes são decrescentes com a distância a partir da borda da cratera: passam de 800 a 850 m nos primeiros 1.500 m a 795 a 810 m após esse limite. As menores altimetrias ocorrem na área de drenagem de um dos afluentes do rio Capivari: o ribeirão Embura, cujos tributários da margem esquerda têm escavado vales bastante aprofundados. As declividades predominantes na área são de 25 a $35 \%$ e se reduzem para 10 a 15\% nas proximidades do ribeirão Cipó.

A drenagem apresenta diversos trechos paralelos à borda da cratera, como os dois principais tributários da margem direita do ribeirão Cipó e um de sua margem esquerda. Os principais tributários do ribeirão Embura, por sua vez, dispõem-se radialmente à cratera, estes com ramificações menores dispostos paralelamente àquela.

No Setor Meridional da Zona de Formas Concêntricas à Cratera predominam formas de relevo denudacionais, com colinas e morros de topos convexos e aguçados (Foto 5). As unidades litológicas de maior extensão compõem o embasamento pré- 
cambriano e compreendem rochas de alto grau de metamorfismo, com predominância dos gnaisses e ocorrência menor de anfibolitos. Também se observam pequenas unidades sedimentares quaternárias e terciárias, dispostas paralelamente à borda da cratera.

O entalhamento dos vales é variável: de 35 a 55 m à distância de até $1.500 \mathrm{~m}$ da crista da cratera e de 30 a 40 m após esse limite. São predominantes os vales em "V", ao passo que poucos vales em berço ocorrem ao longo de alguns dos canais mais importantes. As dimensões interfluviais variam de 100 a 410 m, sem discrepâncias significativas entre as duas faixas de distância da cratera. No entanto, as maiores dimensões interfluviais são correlacionadas com a presença de sedimentos terciários, indicando condicionamento litológico.

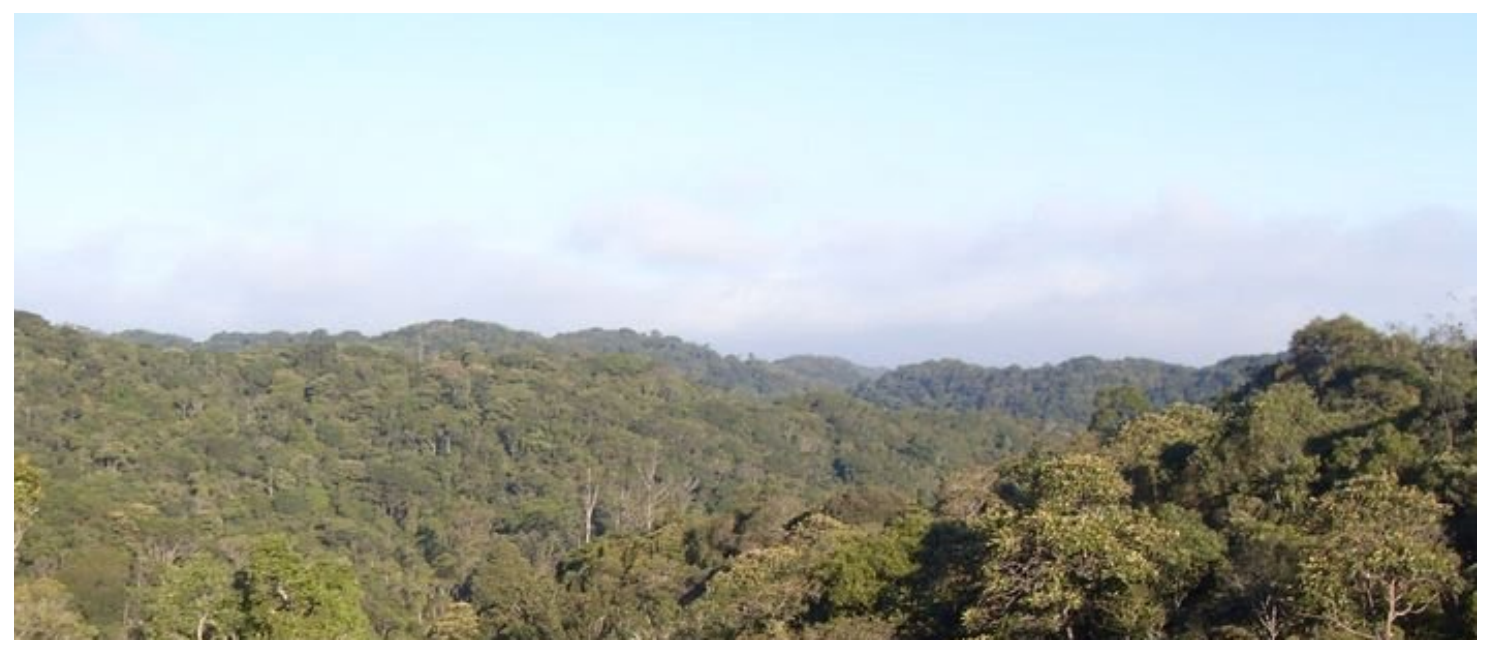

Foto 5 - Vista panorâmica da paisagem no Setor Meridional da Zona de Formas Concêntricas, em Marsilac, na qual se observa forte dissecação do relevo, topos convexos e aguçados e cobertura vegetal densa. Fonte: Panoramio, 2013.

Os níveis dos cumes são nitidamente decrescentes com a distância a partir da borda da cratera: de 800 a $820 \mathrm{~m}$ a até $1.500 \mathrm{~m}$ e de 785 a $800 \mathrm{~m}$ após esse limite. Predominam declividades de 30 a $40 \%$ na primeira faixa e de 35 a $45 \%$ na última. Mais uma vez, observa-se relevo mais dissecado à medida que aumenta a distância a partir da cratera. 
A drenagem é orientada pelas estruturas regionais, de direção predominante leste-nordeste. Dois importantes canais, tributários do ribeirão dos Pombos, orientamse na direção leste-nordeste, condizente com um controle oferecido pelas estruturas regionais. No entanto, essa direção também é paralela à cratera de Colônia, possibilitando um vínculo genético.

Por fim, no Setor Oriental da Zona de Formas Concêntricas à Cratera predominam formas de relevo denudacionais, com colinas e morros de topos convexos. O embasamento litológico constitui-se de gnaisses a sul e de micaxistos a norte. O contato entre as unidades litológicas ocorre ao longo de um tributário da margem esquerda do rio Jurubatuba que desenvolveu uma planície fluvial com sedimentos quaternários. Depósitos quaternários menos extensos ocorrem em vales menores, dispostos preferencialmente na direção de nordeste. Um importante remanescente de sedimentos terciários ocorre a norte, às margens da represa Billings, sustentando os relevos menos dissecados de toda a zona de formas concêntricas (Foto 6).

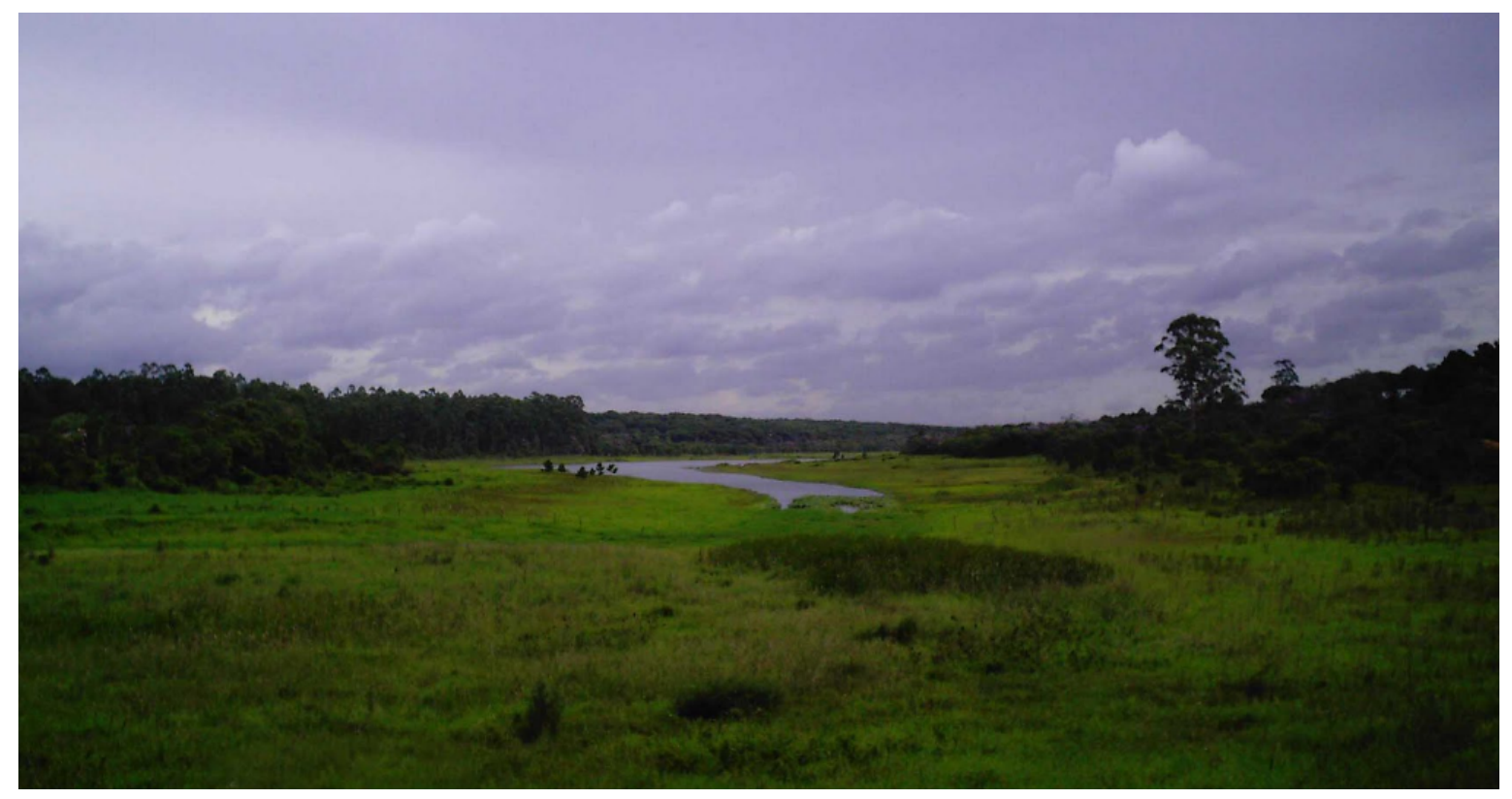

Foto 6 - Paisagem no Setor Meridional da Zona de Formas Concêntricas, às margens da Represa Billings, onde se observa menor dissecação do relevo, com formação de vales mais amplos e drenagem menos confinada. Fonte: Panoramio, 2013. 
O entalhamento predominante dos vales é de 40 a $50 \mathrm{~m}$. Ocorrem vales em "V" nas proximidades da cratera de Colônia, ao passo que vales mais amplos, com forma de berço ou de fundo plano, ocorrem nos setores mais afastados. As dimensões interfluviais típicas são de 140 a 320 m nas proximidades da cratera e de 150 a 470 $\mathrm{m}$ a distâncias superiores a $1.500 \mathrm{~m}$ de sua borda.

Os níveis dos cumes decrescem com a distância a partir da cratera: de 800 a $820 \mathrm{~m}$ a até $1.500 \mathrm{~m}$ de distância e de 775 a $790 \mathrm{~m}$ após esse limite. As declividades predominantes são menores que nos outros setores: de 25 a 35\% na primeira faixa e de 10 a $20 \%$ na segunda faixa. Nos terrenos recobertos por sedimentos terciários, as declividades variam de 10 a 15\%. O Setor Oriental é, conforme os parâmetros morfométricos apresentados, o menos dissecado da zona de formas concêntricas

A rede de drenagem do Setor Oriental apresenta-se menos adensada que nos demais setores que envolvem a cratera, o que é correlacionado com a maior extensão dos sedimentos terciários mapeados. O controle estrutural da drenagem não mostra relação com a cratera: os trechos retilíneos mais significativos ocorrem nas direções de nordeste e sudeste e são raros os trechos radiais ou paralelos à borda da cratera.

Observam-se, a partir da descrição das quatro unidades anteriores, algumas regularidades em suas morfologias: predominância de formas denudacionais; relevo dissecado, com entalhamentos significativos e pequenas dimensões interfluviais; ocorrência majoritária de vales em "V", com poucos vales exibindo morfologia em berço e de fundo plano; níveis mais rebaixados à medida que se aumenta a distância a partir da cratera (com exceção do setor setentrional); rios ajustados à estruturas.

O padrão de drenagem, anelar, resultaria da interferência entre estruturas formadas na ocasião da formação da Cratera de Colônia e outras, produzidas em eventos tectônicos cenozoicos (RICCOMINI et al., 2004). Diversos trechos de drenagem em disposição paralela, sem relação com a cratera, sugerem condicionamento dado por estruturas relacionadas e esses eventos tectônicos.

Destaca-se também o fato de haver maior dissecação nas bordas da zona de formas concêntricas que nos setores mais internos, próximos à cratera. Considerando ter sido o entorno da cratera, logo após sua formação uma superfície constituída por vales e cristas concêntricos, recobertos por uma ejecta rica em sedimentos grosseiros lançados balisticamente a partir do sítio do impacto, espera-se ter ocorrido ali um 
desenvolvimento mais lento do relevo, dados: a menor exposição das cristas internas ao ataque erosivo fluvial e a resistência oferecida pelos referidos sedimentos grosseiros à denudação. Não foram identificados vestígios desses sedimentos grosseiros na área, devido à antiguidade da cratera.

Deste modo, a dissecação mais intensa na faixa mais externa da zona de formas concêntricas condiz com um avanço do entalhamento fluvial de fora para dentro da superfície. Assim, supõe-se ter havido um crescimento remontante gradual dos vales nos quais se localizam os canais que drenam a zona, provenientes de todas as direções a partir do ambiente externo.

\subsubsection{Compartimentos externos à Zona de Formas Concêntricas à Cratera de Colônia}

Descrevem-se os compartimentos geomorfológicos localizados no entorno da zona de formas concêntricas, os quais exibem grande diversidade litológica e morfológica. São eles: as Colinas de Embura, esculpidas em terrenos predominantemente constituídos por sedimentos terciários; a Planície do Ribeirão Embura, esculpida em sedimentos quaternários; as Colinas e Morros da Bacia do Rio Capivari, as Colinas e Morros da Bacia do Rio Jurubatuba e Colinas e as Morros da Bacia do Rio Embu-Guaçu, as três últimas compreendendo extensões das três bacias de drenagem que drenam o entorno da zona.

As Colinas de Embura se estendem pela sub-bacia de mesmo nome, localizada no setor Noroeste da bacia hidrográfica do rio Capivari. Predominam formas denudacionais, com colinas de topos convexos e tabulares, alongadas na direção norte-nordeste, transversalmente ao ribeirão Embura. A área é recoberta, em grande parte, por sedimentos terciários da Formação Resende, havendo exposições pouco extensas de gnaisses do embasamento pré-cambriano nos vales mais aprofundados.

O entalhamento dos vales é de 30 a 50 m e não se altera significativamente ao longo da unidade. Há grande diversidade de formas de vale: enquanto no setor oriental são observados vales em "V" mais entalhados, no setor ocidental, há vales em "V", vales em berço e de fundo plano com fraco declive. As dimensões interfluviais predominantes variam de 250 a 600 m nas colinas esculpidas sobre o embasamento cristalino e de 250 a 720 m nas colinas esculpidas sobre os sedimentos terciários. A 
morfologia da unidade contrasta com a do entorno, dado o menor grau de dissecação do relevo (Figura 21)

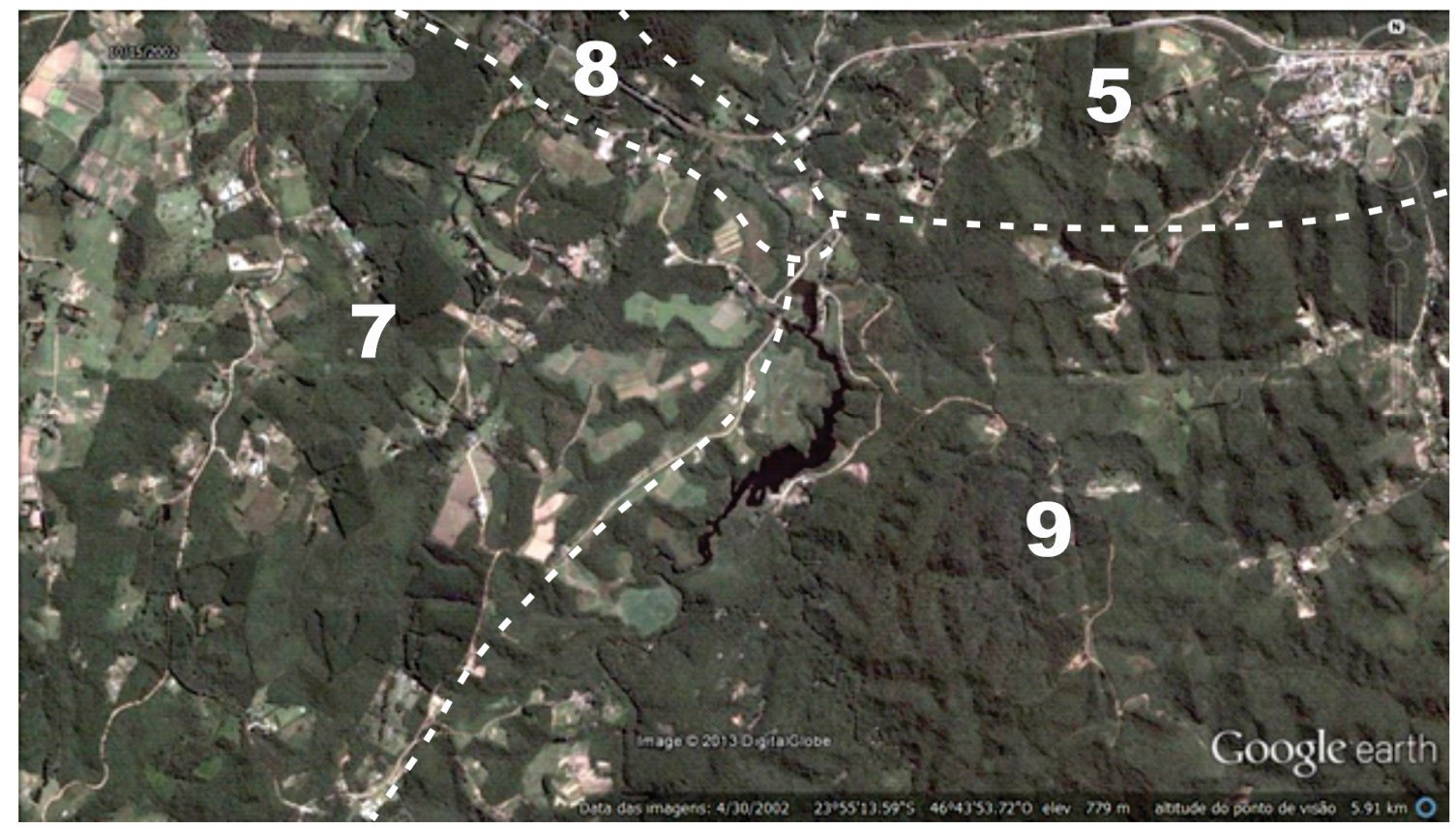

Figura 21 - Colinas de Embura (7), cujo relevo contrasta com o dos morros da Bacia do Rio Capivari (9), estes últimos muito mais dissecados, evidenciando controle litológico: enquanto predominam sedimentos terciários nos primeiros, predominam rochas cristalinas do embasamento pré-cambriano, principalmente gnaisses, nos últimos. Outras unidades representadas: 8 - Planície do Ribeirão Embura, 5 - Morros e Colinas do Setor Meridional da Zona de Formas Concêntricas à Cratera de Colônia. Obtido em Google Earth, 2013.

Os cumes têm altitudes decrescentes de sudoeste para nordeste, variando de $820 \mathrm{~m}$, próximo às cabeceiras do ribeirão Embura, a $780 \mathrm{~m}$ nas proximidades do mesmo, em rampas de baixa inclinação. As declividades são menores que nos demais compartimentos, predominando inclinações de 6 a 12\% nas vertentes das colinas de oeste e superiores a $30 \%$ nas vertentes das colinas de leste. Localizadas próximas da confluência com o rio Capivari, as últimas se estabelecem diretamente sobre o embasamento e possuem vales mais entalhados que as primeiras.

A drenagem da bacia do ribeirão Embura exibe padrão paralelo, com os principais canais fluindo longitudinalmente à direção do mergulho da superfície local, atribuível a um bloco basculado com inclinação para nordeste. Eles encontram o 
ribeirão Embura em ângulos retos, tendo sido proposto anteriormente que a bacia hidrográfica se estruturou com uma saída para noroeste, mais recentemente invertida para sudeste devido à captura do Alto Capivari pela drenagem litorânea (AB'SÁBER, 1957). O ribeirão Embura, canal obsequente em relação ao sítio da captura, teria, juntamente com seus tributários, entalhado no embasamento cristalino e adquirido as direções dadas por estruturas de direção nordeste nas rochas.

A Planície do Ribeirão Embura constitui uma unidade geomorfológica à parte, dadas sua maior extensão em relação às demais planícies fluviais da área e sua posição chave entre as Colinas de Embura e a Zona de Formas Concêntricas, também entre as bacias do Embu-Guaçu e do Capivari. A planície é alongada na direção sudeste e dispõe-se paralelamente aos lineamentos concêntricos do entorno da cratera. Apesar disso, é mais provável que seja controlada por estruturas tectônicas regionais, uma vez que consiste de um segmento de uma zona mais prolongada de lineamentos de direção sudeste.

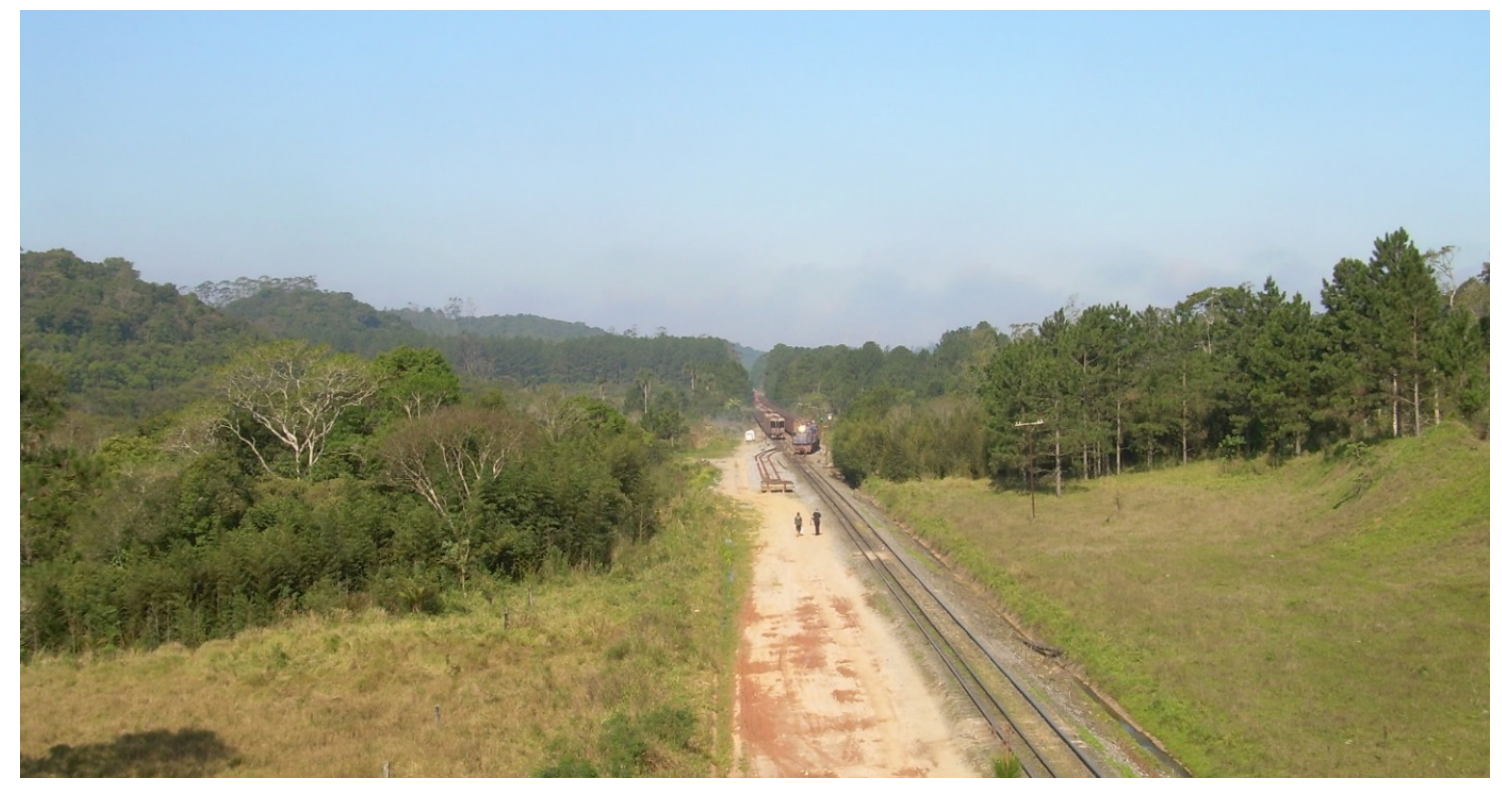

Foto 7 - Vista geral da Planície do Ribeirão Embura, delimitada pela unidade meridional da Zona de Formas Concêntricas (à esquerda) e pelas Colinas de Embura (à direita). Obtida por Santos, 2009. 
Constitui-se por um terreno plano (Foto 7), de natureza sedimentar fluvial quaternária, formado por processos de agradação. Atualmente, parte dos sedimentos encontra-se em degradação, no setor sudeste, em função do entalhamento promovido pelo ribeirão Embura, que atualmente flui para o rio Capivari. Formou-se, na proximidade da confluência entre os dois rios, um conjunto de terraços fluviais, alguns com até $10 \mathrm{~m}$ de desnível, marcando o início do entalhamento.

A unidade das Colinas e Morros da Bacia do Rio Capivari compreende a parcela da referida bacia presente na área de estudo, com exceção da sub-bacia do ribeirão Embura e da área correspondente ao setor meridional da zona de formas concêntricas. Predominam formas de relevo denudacionais, que consistem basicamente de morros baixos e médios com topos convexos e aguçados.

O relevo é sustentado principalmente por gnaisses e ocorrências menores de anfibolitos. Nos fundos dos vales, ocorrem coberturas aluviais quaternárias, acompanhando as principais linhas de drenagem. Pequenos depósitos quaternários formam planícies alveolares, geradas devido à movimentação tectônica recente e às diferenças de resistência das rochas, conforme Ab'Sáber (1966).

O entalhamento dos vales é de 40 a $80 \mathrm{~m}$ e a grande maioria deles tem forma em "V", com raras exceções em áreas de sedimentação quaternária. As dimensões interfluviais mais comuns são as de 180 a $300 \mathrm{~m}$. Trata-se, portanto, de uma área de relevo bastante dissecado.

Os níveis predominantes situam-se entre 660 e 780 m e decrescem para sul. Observa-se um degrau topográfico, de direção norte-nordeste, separando os setores ocidental e oriental da bacia do rio Capivari, no qual ocorre redução de 20 a $30 \mathrm{~m}$ das altitudes médias dos topos dos morros de oeste para leste. Dada sua linearidade, supõe-se origem tectônica para o degrau, em conformidade com as movimentações recentes descritas por Riccomini et al. (2004). Já as declividades são consideravelmente altas, prevalecendo aquelas superiores a $30 \%$.

A rede de drenagem apresenta padrão dendrítico-retangular e forte controle estrutural, com diversos trechos retilíneos orientados a leste-nordeste e a nortenoroeste e alta ramificação. Com nível da base no sopé da Serra do Mar, a bacia do rio Capivari possui bastante capacidade para entalhar. De fato, trata-se da unidade mais dissecada daquelas que circundam a Zona de Formas Concêntricas. 
A unidade dos Morros e Colinas da Bacia do Rio Jurubatuba localiza-se a nordeste da zona de formas concêntricas. Pequena parcela da unidade é descrita na Carta Morfológica, mas os MDEs revelam suas características básicas. Predominam formas de relevo denudacionais cujo modelado constitui-se principalmente de colinas e morros baixos com topos convexos. Também há importantes extensões de formas agradacionais associadas às planícies de inundação dos principais afluentes do rio Jurubatuba.

Suas formas principais são esculpidas em xistos e em suítes graníticas, predominando, nas últimas, formas mais amplas e arredondadas. Há também pequenas unidades isoladas de coberturas sedimentares terciárias. Por fim, nos fundos dos vales principais, como os do rio Caulim e ribeirão Varginha, ocorrem coberturas aluviais quaternárias.

O aprofundamento típico dos vales é de 40 a $60 \mathrm{~m}$. As formas dos vales são bastante diversificadas, havendo aqueles em "V", de fundo plano e em berço, predominando os primeiros. A dimensão interfluvial varia de 170 a $700 \mathrm{~m}$. Os níveis dos cumes são de 780 e $815 \mathrm{~m}$ e as declividades predominantes variam de 6 a 12\%.

A drenagem exibe padrão dendrítico-retangular, com trechos retilíneos orientados principalmente na direção norte-nordeste, além de ramificações menores sem direção preferencial.

Por fim, a unidade dos Morros e Colinas da Bacia do Rio Embu-Guaçu, localizase a noroeste da zona de formas concêntricas e é descrita principalmente segundo dados obtidos de MDEs. Predominam formas de relevo denudacionais cujo modelado constitui-se principalmente de colinas e morros baixos com topos convexos a também formas agradacionais associadas às planícies de inundação dos principais afluentes do Rio Embu-Guaçu.

O aprofundamento médio dos vales é de 50 a $90 \mathrm{~m}$, maior que na bacia do rio Jurubatuba. Já a dimensão interfluvial é menor, de 150 a 350 m, predominando vales em "V". Os níveis dos cumes são de 760 a 780 m, atingindo maiores níveis a norte, nas cabeceiras do ribeirão Caulim e também ao longo do divisor de águas formado entre as bacias dos rios Embu-Guaçu e Jurubatuba. As declividades predominantes são de 15 a $30 \%$ e ultrapassam os $30 \%$ nas proximidades da zona de formas concêntricas. 
Suas formas principais são esculpidas em xistos, gnaisses e granitos. Há pequenas extensões de coberturas sedimentares terciárias e coberturas aluviais quaternárias nos fundos dos principais vales.

A drenagem exibe padrão dendrítico-retangular, com trechos retilíneos orientados principalmente na direção norte-nordeste, sobre quais há clara evidência de controle estrutural por parte das foliações dos micaxistos e de fraturas do corpo granítico a norte, além de ramificações menores sem direção preferencial.

Com base na descrição apresentada, observa-se, no entorno mais distante da cratera de Colônia, um contraste entre as formas a sul, mais dissecadas e rebaixadas, e a norte, onde predominam colinas mais amplas e cotas altimétricas maiores. Isso não reflete a diversidade litológica, tendo maior relação com a tectônica e com o entalhamento produzido pelas redes de drenagem. Há, ainda, uma diferenciação no sentido leste-oeste, com terrenos mais rebaixados e planos na bacia do rio Jurubatuba que na bacia do rio Embu-Guaçu, o que provavelmente relaciona-se com a própria evolução das referidas bacias hidrográficas.

\subsection{POSSÍVEIS MECANISMOS PARA A FORMAÇÃO DE UMA ZONA DE FORMAS CONCÊNTRICAS}

A padronagem concêntrica da drenagem e do relevo no entorno da cratera de Colônia apresenta evidências de condicionamento estrutural. Seria este o responsável pelos trechos retilíneos da drenagem, dispostos radial e paralelamente à cratera e pela consequente formação de vertentes e cumes orientados do mesmo modo. Sem esse condicionamento, as direções das linhas de drenagem e dos cumes das colinas e morros teriam maior aleatoriedade.

O padrão de formas observado provavelmente possui vinculação genética com a origem da cratera de Colônia, dado o forte ajustamento geométrico entre os mesmos. O limite dessa área ajusta-se a um elipse praticamente concêntrico ao da cratera, com uma separação de apenas $54 \mathrm{~m}$ entre seus respectivos centros, além da ocorrência de diversos lineamentos radiais e concêntricos, tornando improvável que dois eventos distintos tenham gerado tal coincidência de formas.

Considerando-se a referida vinculação genética, o padrão concêntrico só não é mais evidente em razão da antiguidade da cratera de Colônia, de idade pliocênica a 
oligocênica (RICCOMINI et al., 2011). Deste modo, o modelado inicial, a partir do momento da origem da cratera, teria sofrido modificação ao longo do tempo, levando a seu progressivo desaparecimento. Trata-se de uma forma reliquial, na acepção de Tricart (1965), modificada conforme as condições tectônicas e climáticas existentes na área.

Cabe refletir sobre a origem da zona de formas concêntricas. Apesar de não haver estudos geofísicos que detalhem a disposição de fraturas existentes no entorno da cratera, necessárias à interpretação do condicionamento estrutural da evolução geomorfológica da área, tendo-se em vista a gênese da cratera por impacto, estabelecida por Velázquez et al. (2013) e a hipótese da vinculação genética do relevo do entorno com a origem da cratera, examinam-se diferentes modos pelos quais se formam estruturas concêntricas derivadas de impactos, candidatas a uma explicação da origem do relevo da área. Os mecanismos considerados são: formação de fraturas radiais e concêntricas no entorno de crateras de impacto, estratificação do alvo, formação de pico anelar, ejecta fluidificada e fluidificação de finos.

Na hipótese da formação de uma topografia condicionada por fraturas radiais e concêntricas, nota-se que estas são feições comumente encontradas dentro e fora dos limites da borda da cratera de impacto. Estudos realizados nas estruturas Lonar e Tvaren (KUMAR e KRING, 2008; HENKEL et al., 2010), apontam haver formação de uma zona de fraturas radiais e concêntricas que se estendem a até 0,33 raio da cratera para além de sua borda. Na cratera de Colônia, a zona de formas concêntricas (2.575 m de largura, em média) é muito mais ampla que o raio do anel colinoso da cratera ( $1.800 \mathrm{~m}$, em média), estendendo-se a 1,43 raios da cratera para além de sua borda.

Considerando-se tal discrepância, pode-se então creditar a maior extensão da zona de formas concêntricas: 1) a alguma propriedade do bólido ou do alvo, que tornou a zona de fraturas radiais e concêntricas mais ampla; ou 2) à atuação de outro mecanismo, que substituiria ou complementaria a formação da rede de fraturas. Assim, os demais mecanismos, que podem ter agido em conjunto com este para formar a zona de formas concêntricas, são considerados.

Avalia-se, inicialmente, o mecanismo da formação de crateras concêntricas a partir da escavação de um alvo estratificado, com uma camada pouco resistente sobreposta a uma camada muito resistente, conforme estudos de Oberbeck e Quaide 
no final dos anos 1960 (MELOSH, 1989). Considerando-se a história geológica da área em questão, admite-se ter havido um alvo estratificado, no qual sedimentos terciários da Formação Resende recobriram, até o Plioceno, as rochas cristalinas do embasamento pré-cambriano (RICCOMINI et al., 2004), as últimas mais resistentes que as primeiras.

$\mathrm{Na}$ região de Colônia, as unidades terciárias correspondem, para Ab'Sáber (1957), aos "testemunhos e agrupamentos de testemunhos da fase de expansão máxima da sedimentação flúvio-lacustre", que capeiam encostas, plataformas interfluviais ou pequenos compartimentos relativamente isolados das áreas periféricas da bacia. O pacote sedimentar era pouco espesso na área, já bastante afastada da região de profundidade máxima, no centro da bacia, de aproximadamente $250 \mathrm{~m}$, na região da Mooca, considerando-se que naquela região o embasamento se encontra à profundidade de $541 \mathrm{~m}$ e o topo da deposição chega aos $820 \mathrm{~m}$, na Vila Clementino (VARGAS, 2002).

Estimando-se um valor de $50 \mathrm{~m}$ para a espessura do pacote sedimentar no local e na época de formação da cratera de Colônia - valor este provavelmente superestimado - obtém-se relação D / tL (diâmetro / espessura da camada de menor resistência) igual a 72. Esse valor é muito superior ao necessário para formar um duplo anel soerguido, o que ocorre quando $\mathrm{D} / \mathrm{t}_{\mathrm{L}}=10$, conforme o modelo de Quaide e Oberbeck (1968) apud Melosh (1989). Nas condições dadas, apenas seria possível a formação de um pequeno terraço ou bancada na parede interna da crista, correspondente ao limite entre as duas unidades litológicas. Seria necessário elevar a espessura da bacia para 360 m para gerar a feição representada na Fig 16(d), valor este muito improvável para a área em questão.

Assim, a hipótese da estratificação do alvo não é candidata forte para explicar a topografia concêntrica no entorno da cratera. Ela também não explica as feições concêntricas intermediárias existentes entre a borda externa e interna da zona de formas concêntricas - sendo necessário recorrer à atuação conjunta do fraturamento radial e concêntrico do embasamento cristalino para explicá-las.

Outra hipótese a ser examinada é a de que a feição foi produzida pela degradação erosiva de uma cratera complexa com morfologia de pico anelar. Nela, a borda da zona de formas concêntricas corresponderia à borda da estrutura de impacto. Já a cratera de Colônia, compreendida pelo anel colinoso de 
aproximadamente $3.600 \mathrm{~m}$ de diâmetro, seria, na realidade, apenas o pico anelar dessa estrutura. A hipótese evita as dificuldades da necessidade de pacote sedimentar espesso, pois o mecanismo independe da estratificação do alvo. Também explica a existência das feições concêntricas intermediárias, entre o anel colinoso da cratera e da borda da zona de formas concêntricas, atribuíveis a terraços estruturais com frentes orientadas para centro da estrutura formadas durante os processos desencadeados no impacto.

O modelo hidrodinâmico (MELOSH, 1989) e o modelo da Cavidade Fundida Aninhada (BAKER et al., 2011) preveem a formação de várias ondulações geradoras de aneis concêntricos. Enquanto o primeiro modelo prevê cominuição e consequente comportamento hidrodinâmico do material rochoso, formando as ondulações concêntricas, o segundo prevê fusão de todo o material envolvido. A ausência de unidades ígneas sustentando 0 anel colinoso permite descartar o segundo mecanismo.

O modelo hidrodinâmico explicaria ainda a anomalia de profundidade da cratera de Colônia, observada por Riccomini et al. (2011). Para os autores, a anomalia seria explicável por parâmetros relacionados ao bólido - como composição, tamanho, velocidade e ângulo do impacto - ou pela profundidade atingida pela degradação erosiva da estrutura. Já o modelo hidrodinâmico prevê a formação de um pico anelar central de pequena altura em relação ao diâmetro (MELOSH, 1989), observando-se crateras complexas que exibem pico anelar que que correspondem a menos de 1/5 da altura da crista externa (BAKER et al., op cit).

A hipótese do pico anelar também encontra sustentação na razão entre os diâmetros do Anel Colinoso e da borda da zona de formas concêntricas, de 0,41. A razão empiricamente identificada entre os diâmetros do pico anelar e da borda da respectiva cratera é de 0,5, com considerável dispersão de valores, chegando a 0,4 em algumas estruturas (Gráfico 1).

A análise das rupturas de declividade na área não refuta ou corrobora a hipótese de formação de pico anelar. Há diversas rupturas paralelas à borda cratera, como observado na Carta Morfológica (Anexo 1), relacionáveis às ondulações e falhamentos concêntricos geradas conforme o modelo hidrodinâmico. No entanto, a presença de rupturas de direções muito variadas também é atribuível a outras 
mecanismos, relacionados à tectônica ou à gênese da cratera de Colônia, dificultando seu uso no teste da hipótese.

As maiores dificuldades da hipótese consistem na pequena extensão da zona de formas concêntricas, reduzida demais frente aos $25 \mathrm{~km}$ necessários para o desenvolvimento de picos anelares na Terra, bem como na persistência das estruturas regionais no interior da zona e a consequente persistência dos lineamentos de direção regional nessa área. A formação de uma cratera complexa com pico anelar levaria à obliteração das estruturas geológicas prévias, em grande profundidade, de tal modo que os lineamentos no interior da estrutura apresentariam orientações muito diferentes do exterior.

Outra dificuldade é comum às hipóteses do pico anelar e da estratificação do alvo: elas tornariam necessário revisar o tamanho da cratera para aproximadamente $8.750 \mathrm{~m}$, correspondente ao diâmetro médio da zona de formas concêntricas. Tal diâmetro exigiria um impacto muito mais intenso que o necessário para produzir uma cratera de cerca de $3.600 \mathrm{~m}$, o que provocaria alterações mais significativas na geologia da região, como produção de unidades ígneas e deposição de maior quantidade de fragmentos rochosos de grandes dimensões, o que não foi observado na área até o momento.

Os dois mecanismos apresentados a seguir não exigem revisão do tamanho da cratera, pois atingem apenas camadas superficiais: ejecta fluidificada e fluidificação de finos. No entanto, também enfrentam dificuldades, devido à antiguidade da cratera de Colônia e à rápida degradação de feições superficiais em crateras de impacto, como no caso da cobertura de ejecta, que desaparece em seus estágios iniciais de evolução (DENCE, 1972).

A região de Colônia reuniria condições favoráveis para a formação de uma cobertura de ejecta fluidificada, considerando-se a possível existência de um ambiente saturado em água na época do impacto. Sedimentos pós-eocênicos marcam a existência de ambientes majoritariamente úmidos, documentados nos sedimentos de origem lacustre e fluvial meandrante (RICCOMINI et al., 2004), o que se intensificou com o soerguimento responsável pela formação da escarpa da Serra do Mar, que passou a impor efeito orográfico ao regime de precipitações. O relevo deve ter sido menos dissecado que o atual, considerando que o retrabalhamento erosivo da Bacia de São Paulo foi mais intenso a partir do Plioceno (AB'SÁBER, 1957). 
Na hipótese da ejecta fluidificada, a borda da zona de formas concêntricas corresponderia à borda da cobertura de ejecta fluidificada, terminada em uma feição do tipo "rampart". De fato, nota-se que a borda da zona é marcada por um anel soerguido, atualmente muito fragmentado e pouco conspícuo. Neste modelo, a crista seria sustentada pelos depósitos grosseiros entremeados a finos no processo de posicionamento da ejecta - semelhante a uma corrida de lama.

A razão entre os diâmetros das crateras de impacto e da borda da cobertura de ejecta fluidificada, de 0,5 , também é próxima da razão entre os diâmetros observados na área entre o Anel Colinoso e a borda da zona de formas concêntricas.

A hipótese ainda escapa da dificuldade da persistência dos lineamentos regionais na topografia da zona, pois seu efeito seria apenas superficial. No entanto, a ejecta fluidificada não exibe estruturas de padrão radial e concêntrico capazes de orientar drenagem posteriormente formada. A hipótese não explica, portanto, a existência de aneis concêntricos intermediários. O padrão anelar necessitaria de outro mecanismo para se desenvolver.

Outra dificuldade está na morfologia regular da borda da zona de formas concêntricas (onde ela é identificável) contrastante com as morfologias festonadas das bordas das coberturas de ejecta fluidificada apresentadas na Figura 12 e na Figura 13.

A maior dificuldade à hipótese da ejecta fluidificada, contudo, é o fato de que os depósitos de ejecta são rapidamente removidos pela erosão (DENCE, 1972). Mesmo que tenha havido a formação de depósitos grosseiros, é pouco plausível que os mesmos tenham resistido a ciclos erosivos de mais de 5 milhões de anos. Em campo, os mesmos não foram identificados na faixa correspondente à borda da zona de formas concêntricas, predominando materiais finos e areias.

Por fim, a hipótese da fluidificação de finos prevê a formação de uma estrutura concêntrica em uma camada constituída por materiais argilosos e sua degradação erosiva, gerando um relevo de formas concêntricas. Conforme modelo da fluidificação de finos, sedimentos argilosos teriam se fluidificado na passagem da onda de choque e gerado tal estrutura, comportando-se hidrodinamicamente, logo depois solidificando-se. Diferentemente do modelo do pico anelar e análogo ao da ejecta fluidificada, não atinge as rochas do embasamento cristalino, mas apenas a cobertura 
de finos, explicando persistência dos lineamentos regionais na topografia interna à zona de formas concêntricas.

As condições necessárias à sua formação estão presentes na área: dados de sondagens das camadas sedimentares da bacia de São Paulo mostram presença da fração argilosa, com deposição em ambiente fluvial (ABGE, 2002; RICCOMINI et al., 2004).

Remanescentes sedimentares, na região de Colônia, compreendem depósitos distais da Formação Resende, eocênica a oligocênica, constituídos por lamitos, com ocorrência subordinada de lentes arenosas e conglomerados de sistema fluvial entrelaçado. As demais formações sedimentares da Bacia de São Paulo não deixaram remanescentes na área, com exceção da Formação São Paulo, relatada por Riccomini et al. (1991). De idade neo-oligocênica, esta última compõe-se de depósitos arenosos, siltosos e argilosos de sistema fluvial meandrante.

A maior dificuldade dessa hipótese é a preservação das ondulações concêntricas a longo prazo após mais de 5 Ma de formação da estrutura, período no qual ocorreu a remoção das camadas sedimentares deformadas. Seria necessária a ocorrência de um processo de superimposição da drenagem, de modo a produzir um padrão anelar, herdado da camada sedimentar superior, na camada cristalina inferior.

O processo de superimposição é documentado em grandes cursos d'água, como o Rio Vaal, que atravessa a estrutura de Vredefort, e o Rio Griqua, na região do Karoo, ambos na África do Sul (TWIDALE, 2004). Mas sua ocorrência em menores canais é pouco provável devido ao maior ajustamento destes às estruturas (MORISAWA, 1985). Nota-se, portanto, a insuficiência desta última hipótese para explicar a existência de cursos d'água de menor ordem seguindo orientações radiais e concêntricas à cratera de Colônia.

A presença de dados geofísicos é crucial para se identificar positivamente a origem do condicionamento da estrutura de feições concêntricas à drenagem e ao relevo. A existência de uma estrutura concêntrica somente será estabelecida se houver estudos geofísicos mais detalhados no entorno da cratera, com obtenção de perfis geofísicos dos estratos rochosos da área.

Os estudos geofísicos realizados na área detalham o interior da cratera de Colônia, mas não seu exterior. Na Figura 22, apresentam-se dados gravimétricos do 
entorno da cratera (PASSOS, 1998). Nota-se a presença de anomalias gravimétricas positivas no entorno da cratera, podendo indicar unidades litológicas mais densas. Não corroboram ou refutam especificamente alguma das hipóteses apresentadas anteriormente, mas apresentam certo grau de correspondência com zona de formas concêntricas.

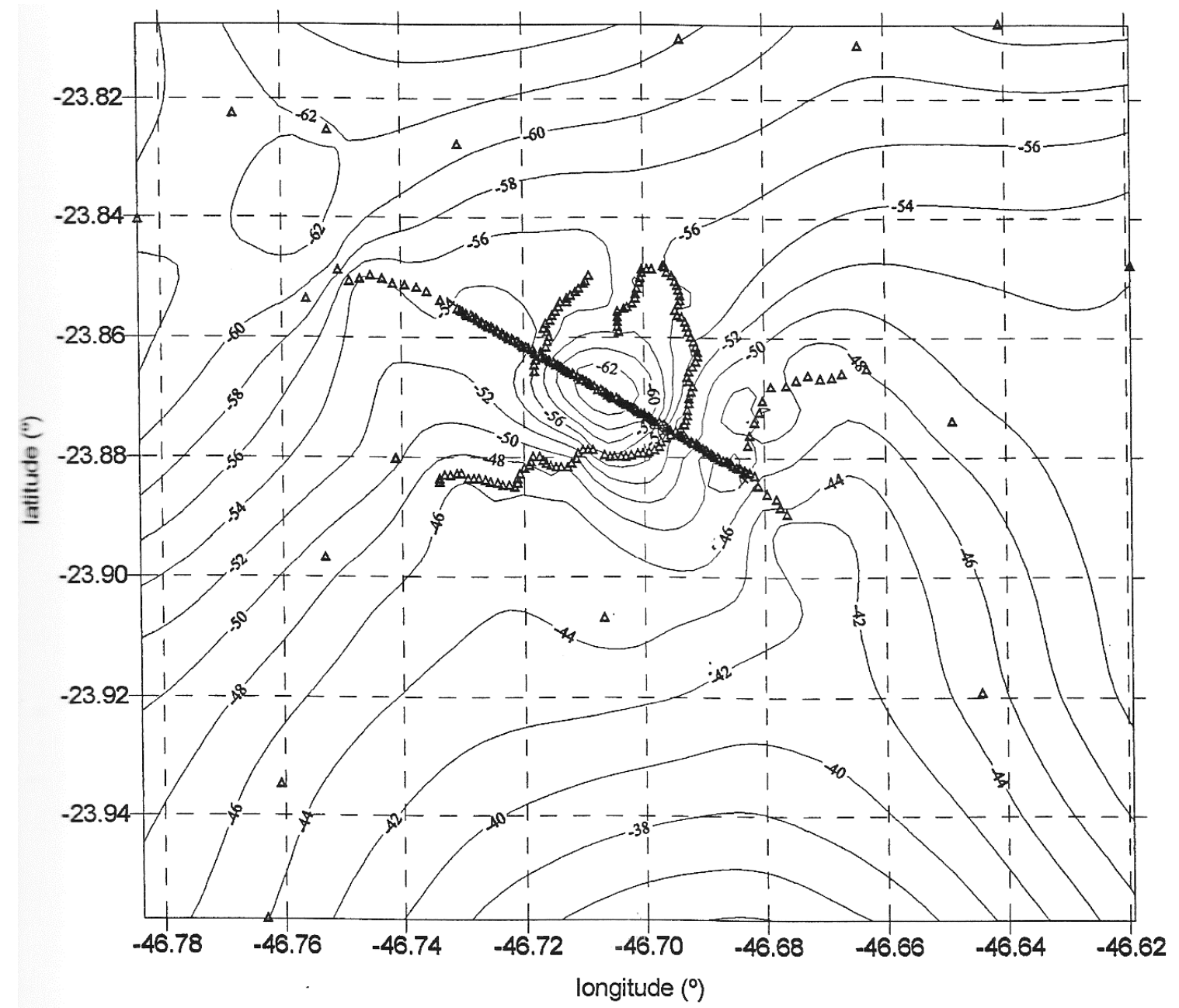

$\Delta$ Estações gravimétricas

Figura 22 - Anomalia Bouguer na região de Colônia, em mGal. Notar padrão concêntrico no entorno da cratera de anomalias positivas, possivelmente relacionadas com a formação de uma estrutura concêntrica à cratera. Extraído de Passos, 1998.

A anomalia gravimétrica constitui evidência para a existência de uma estrutura concêntrica produzida pelo mesmo evento que produziu a cratera. Porém é necessária 
cautela ao se estabelecer um vínculo entre a topografia e os dados geofísicos, dado o baixo grau de detalhamento de seu mapeamento. Como afirmado por Melosh (1989), a respeito da origem de feições concêntricas em crateras de impacto, "há tantas interpretações quanto interpretadores". Deve-se, assim, considerar ainda a possibilidade de que algum mecanismo não mencionado tenha ocasionado o padrão observado de formas do relevo.

\subsection{DESENVOLVIMENTO DA DRENAGEM E DO RELEVO NO ENTORNO DA CRATERA DE COLÔNIA}

O rio e a bacia hidrográfica possuem, para Leopold et al. (1964), uma herança, em vez de uma origem. Assim, como formas orgânicas, são produtos de uma linha evolucionária ao longo do tempo, dificultando a ideia de uma condição "inicial" para uma rede de drenagem. No entanto, em um processo de impacto de bólido extraterrestre, a drenagem precedente é inteiramente destruída. Nesse caso especial, tanto o relevo instantaneamente formado (em poucos segundos a minutos) quanto as rochas deformadas pelo impacto constituiriam uma condição inicial para o desenvolvimento de uma nova rede fluvial, sem influência da drenagem prévia.

Diversos elementos característicos de uma estrutura de impacto - depressões central e concêntricas, picos ou aneis colinosos, fraturamento radial e concêntrico, unidades ígneas e metamorfizadas por impacto - exercem influência no desenvolvimento subsequente da rede de drenagem. Na formação de estruturas de impacto, o fluxo de escavação pode destruir estruturas antigas, ou mesmo aproveitálas, como no caso da cratera do Meteoro (MELOSH, 1989), de tal modo que elas persistem enquanto condicionantes da drenagem. Nas zonas mais periféricas das estruturas de impacto, as novas estruturas sobrepõem-se às antigas, gerando uma área de interferência entre estruturas de diferentes origens e produzindo uma rede de drenagem de organização espacial mais complexa.

$\mathrm{Na}$ área em questão, busca-se discernir o condicionamento oferecido pela presumível estrutura de feições concêntricas daquele oferecido pelas estruturas regionais, ou mesmo pela própria dinâmica tectônica da área. Deste modo, analisa-se um possível caso de interferência entre estruturas geológicas de diferentes origens no desenvolvimento da rede de drenagem, a partir de uma condição inicial pós-impacto. 
O Mapa 14 exibe a drenagem da região de Colônia, obtida por meio de fotointerpretação e correção geométrica dos overlays obtidos. Nele é possível observar a disposição geral da drenagem na área. Observa-se o padrão anelar dendritificado existente no entorno da cratera e o padrão radial centrípeto em seu interior. Os cursos d'água formam um arranjo sugestivo de controle estrutural, característica que exige um exame mais minucioso, conforme apresentado a seguir.

No Mapa 15, destacam-se os lineamentos identificados na rede de drenagem, ou seja, trechos retilíneos dos canais fluviais sugestivos de controle estrutural. Os lineamentos da drenagem do entorno da cratera são comparados com os lineamentos regionais do relevo (Mapa 16).

A partir desses mapas, foram elaborados diagramas de roseta, nos quais se exibem as orientações preferenciais das linhas de drenagem no entorno da cratera de Colônia, divididas por setor (Gráficos 4 a 7) e consideradas em conjunto (Gráfico 8). Já o Gráfico 9 exibe as orientações das estruturas geológicas identificadas na área, como falhas e direções de foliações, conforme Coutinho (1980). Para comparação das orientações dos lineamentos locais com os regionais, produziu-se, ainda, o Gráfico 10 , que exibe as orientações regionais do relevo conforme mapeamento topográfico na escala 1:50.000.

As cartas de lineamentos e os diagramas de roseta mostram que nos setores norte, oeste e sul da zona de formas concêntricas são mais frequentes os lineamentos nas direções norte-noroeste e leste-nordeste. Já no setor leste, predominam lineamentos de leste-oeste e sul-sudeste. Nos setores sul e norte também são muito frequentes os lineamentos de direção norte-sul.

Os lineamentos de direção leste-oeste no setor leste e os lineamentos de direção norte-sul nos setores sul e norte podem indicar controle oferecido por fraturas radiais à cratera de Colônia, embora não seja descartado o controle por estruturas tectonicamente produzidas. Já os lineamentos concêntricos à borda da cratera, por se disporem em direções variadas, não produzem uma barra de maior frequência, mas uma dispersão maior dos valores de orientação obtidos, em qualquer dos setores da zona de formas concêntricas. Eles são melhor identificados nos mapas de lineamentos (Mapa 15) e nos mapas de canais orientados (Mapas 17 e 18). 


\section{Canais fluviais}

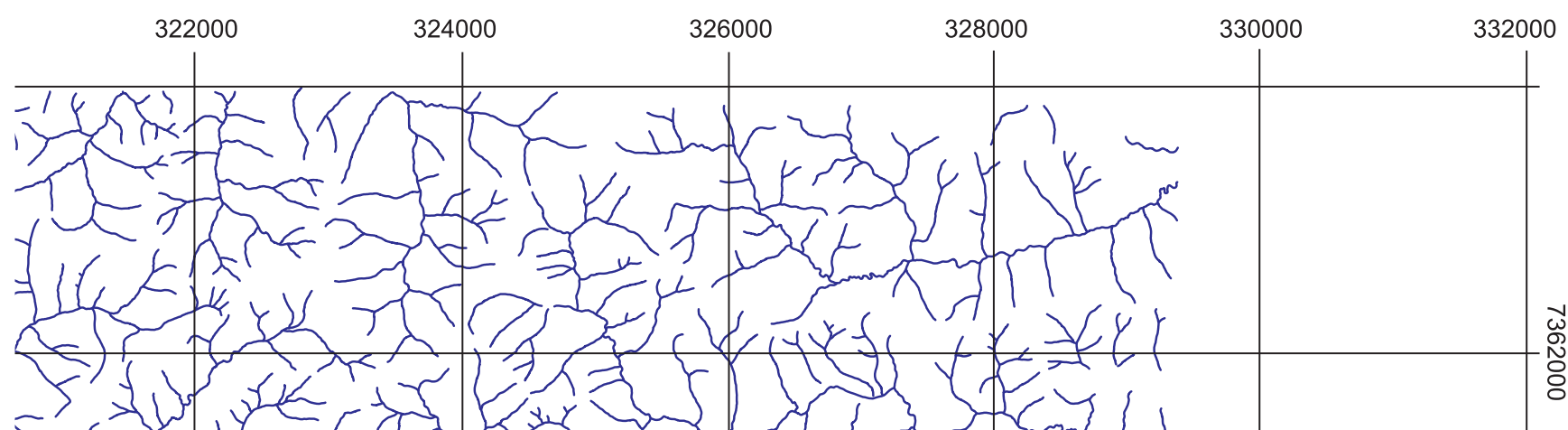

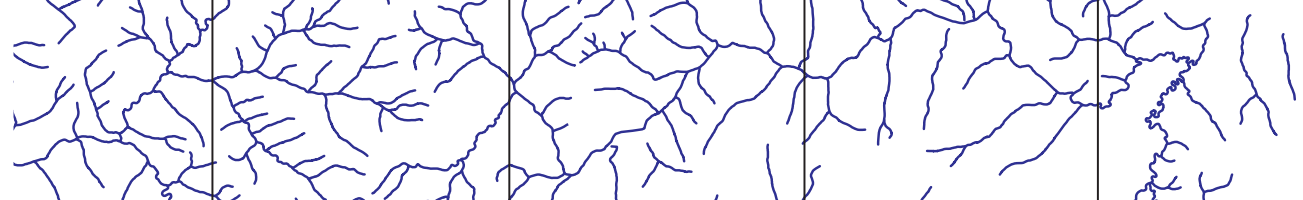

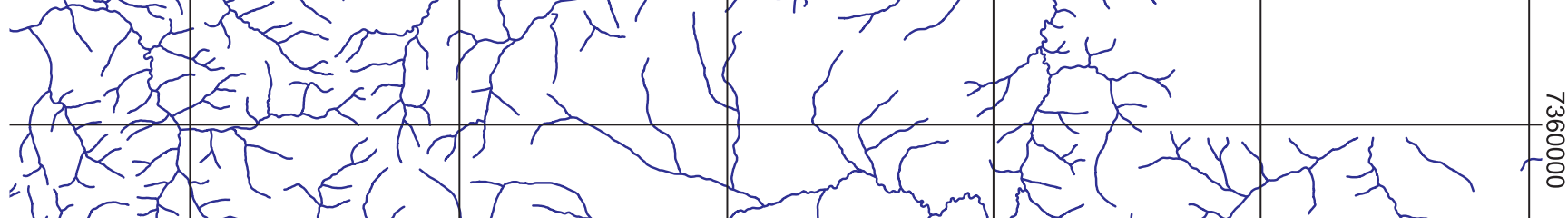

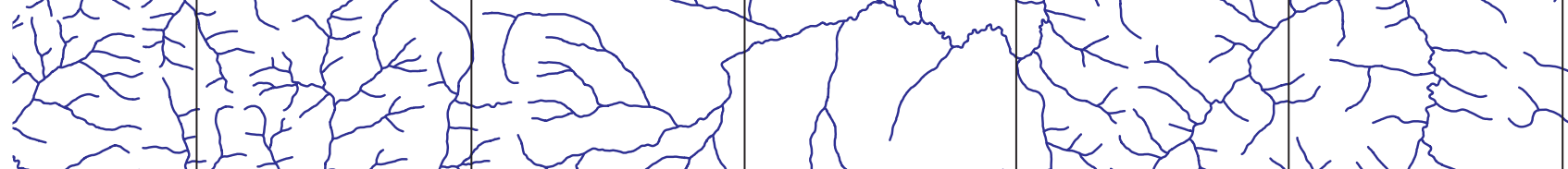
作

32 S s
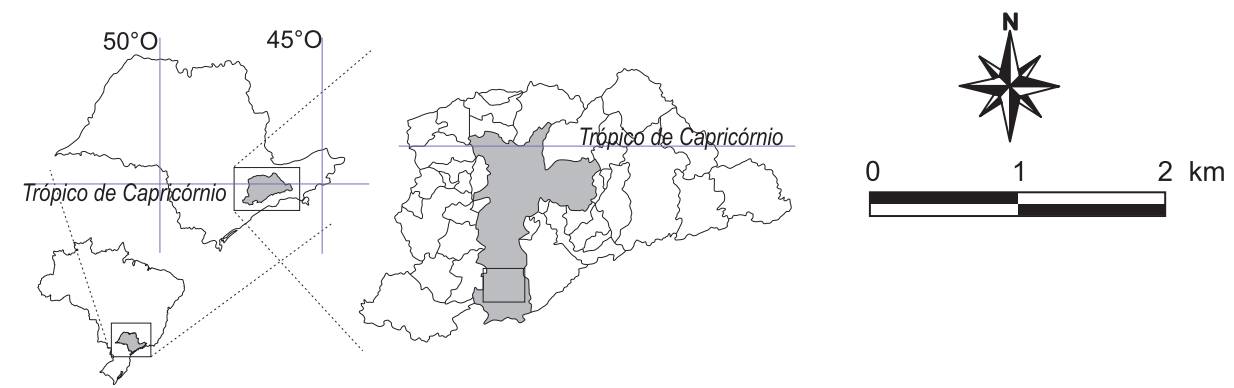

FONTE

- IS/Várias Empresas: Levantamento aerofotogramétrico «Estado de

São Paulo»: Escala 1:25.000, 1962.

Elaborado por Santos, 2013 
Mapa 15. COLÔNIA - SÃO PAULO, SP
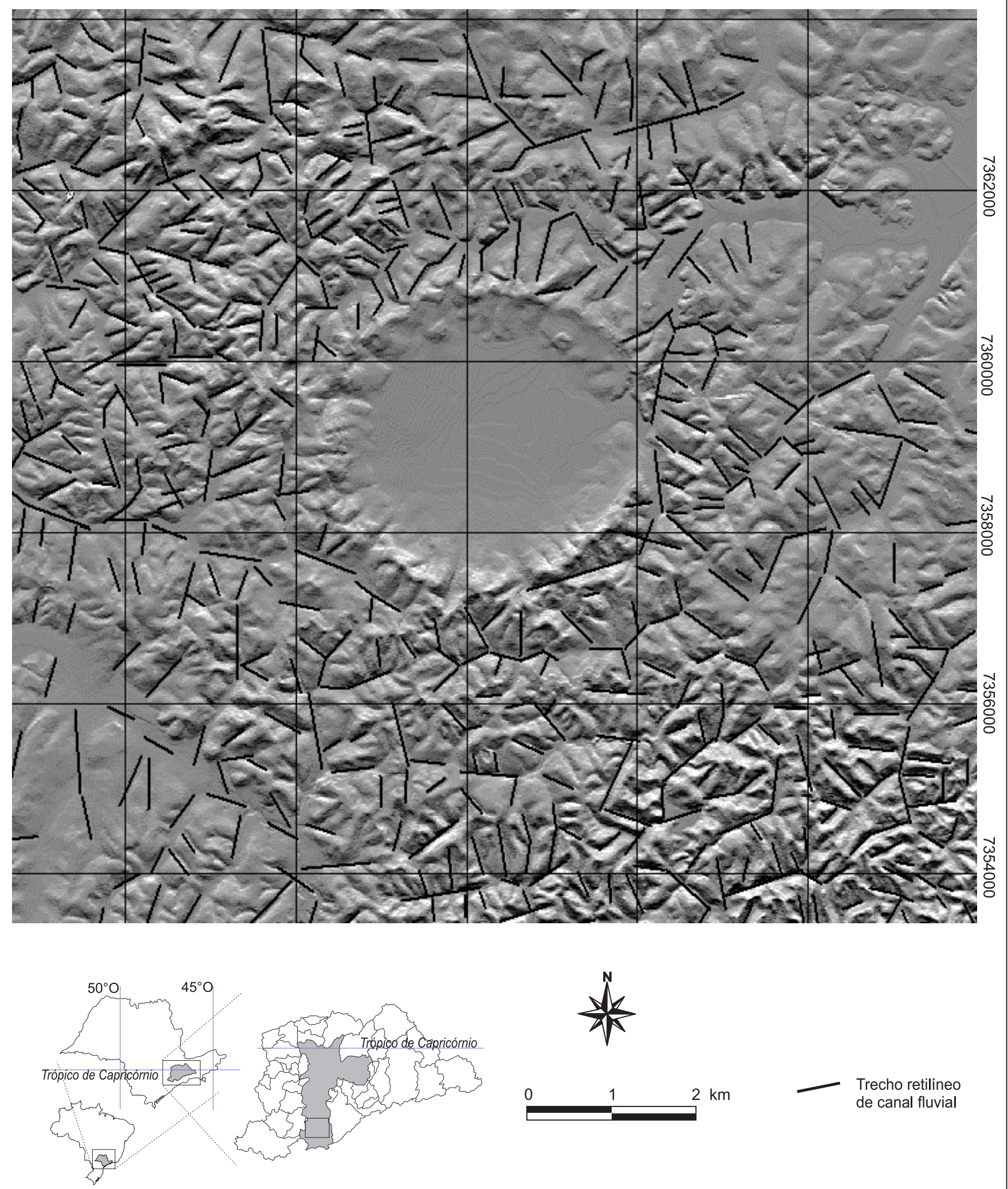

FONTE

- EMPLASA: Mapa topográfico - São Paulo-SP: Região Metropolitana Escala 1:10.000, 1980

- IS/Várias Empresas: Levantamento aerofotogramétrico «Estado de São Paulo»: Escala 1:25.000, 1962. 
Mapa 16. COLÔNIA - SÃO PAULO, SP

Carta de lineamentos topográficos sobreposta ao modelo sombreado
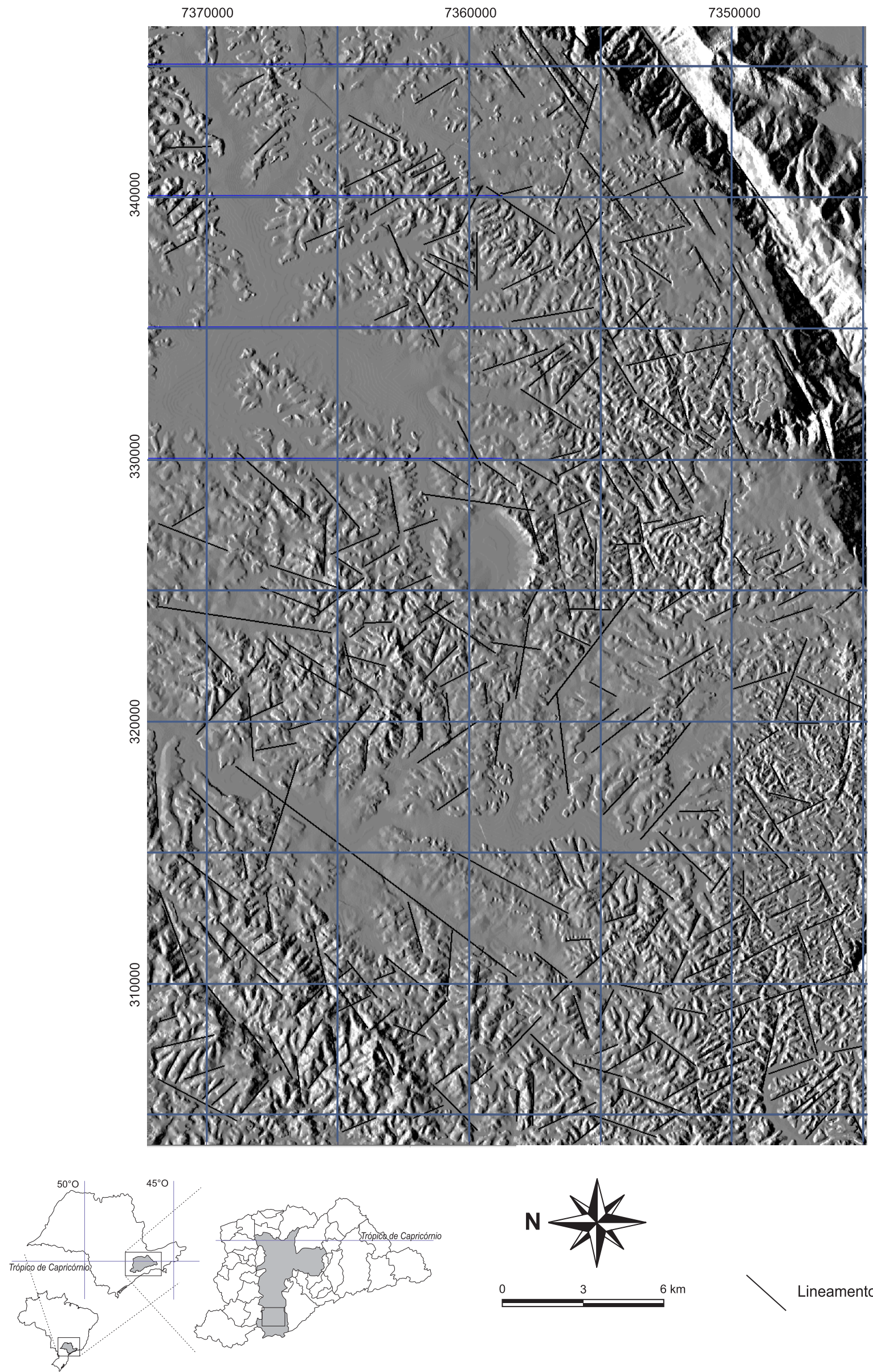

FONTE

BGE Carta Topográfica. Folhas: Riacho Grande e EmbuGuaçu. Escala 1:50.000, 1980. 


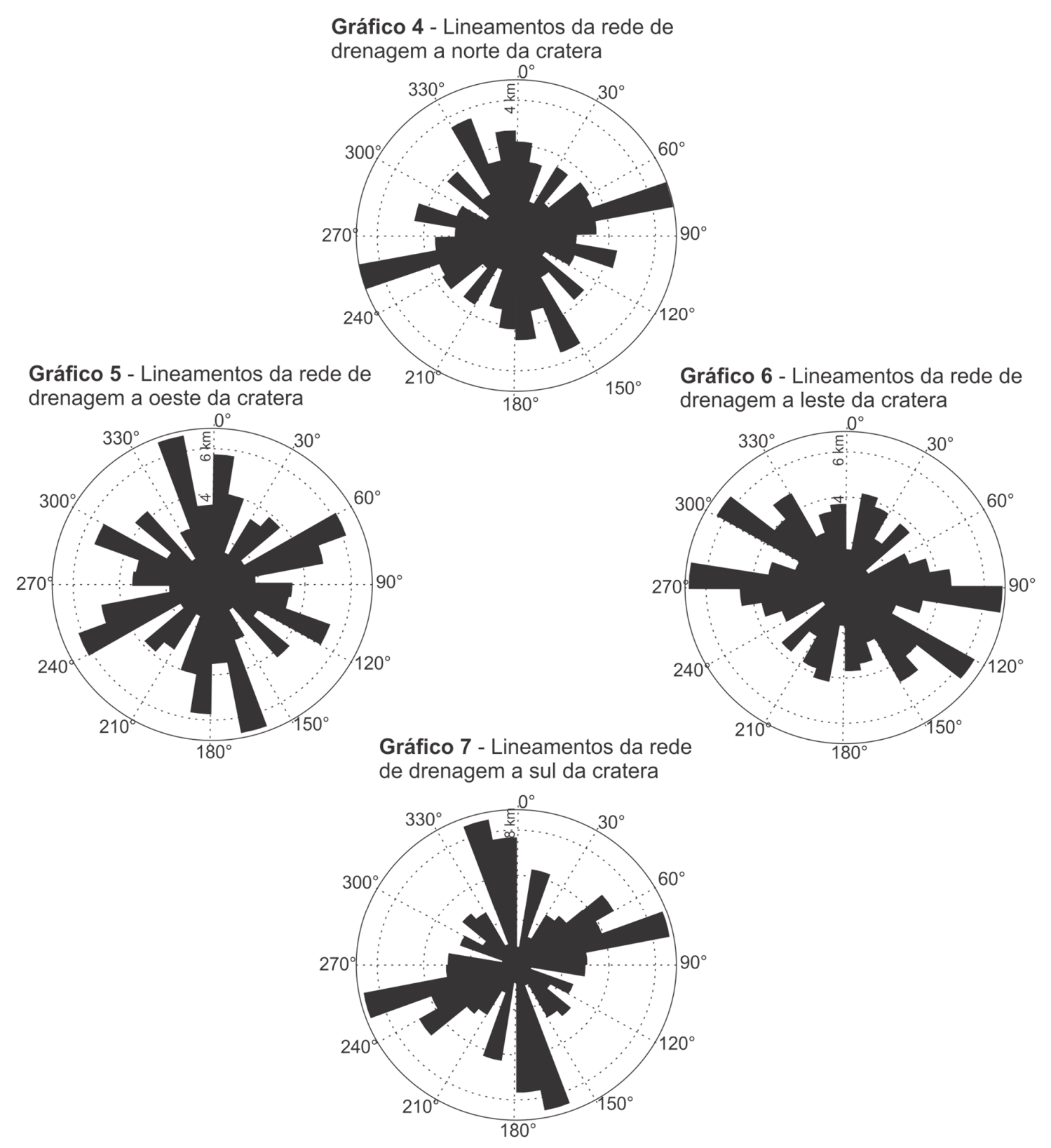


Gráfico 8 - Lineamentos da rede de drenagem no entorno da cratera

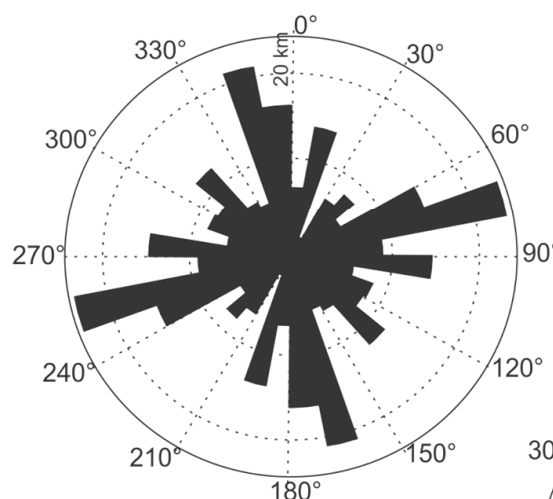

Gráfico 9 - Direções das estruturas geológicas mapeadas (foliações e falhas) no entorno da cratera

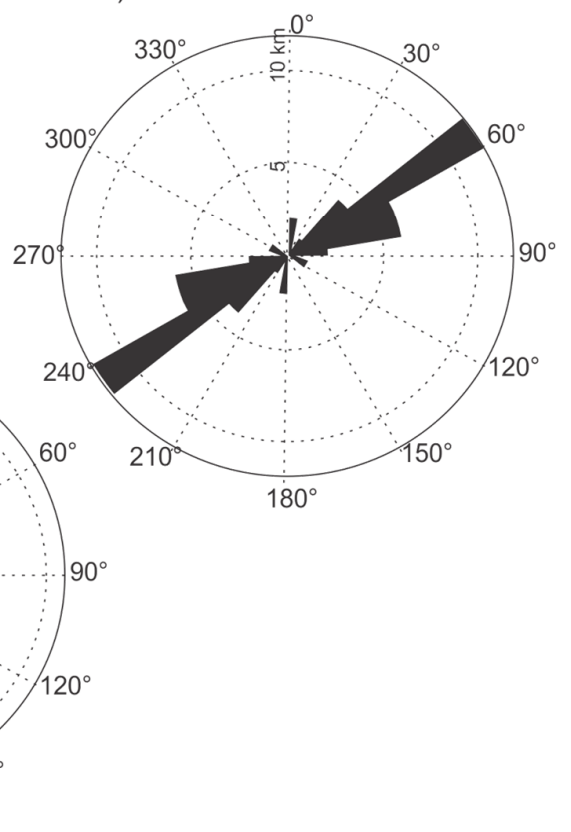

Gráfico 10 - Lineamentos topográficos na escala regional $(1: 50.000)$

Os lineamentos regionais são, por sua vez, de direção predominante lestenordeste. Tal similaridade com os lineamentos predominantes no interior da zona de formas concêntricas indica que a formação da estrutura de impacto não levou à obliteração da estrutura prévia. No entanto, a existência de diversos lineamentos dispostos radial e paralelamente à cratera no interior da zona concêntrica seria indicativo da interferência entre duas estruturas.

$\mathrm{Na}$ análise dos Mapas 17 e 18, que dão destaque aos canais orientados radial e paralelamente à cratera de Colônia, observa-se que, de um total de 880 trechos de canais fluviais mapeados no interior da zona de formas concêntricas, 86 apresentamse orientados radialmente e 142 concentricamente à cratera, totalizando 228 trechos canais orientados, ou 25,9\% do total. Além disso, a observação dos trechos orientados permite delinear a posição de possíveis estruturas relacionáveis ao impacto de bólido extraterrestre. 

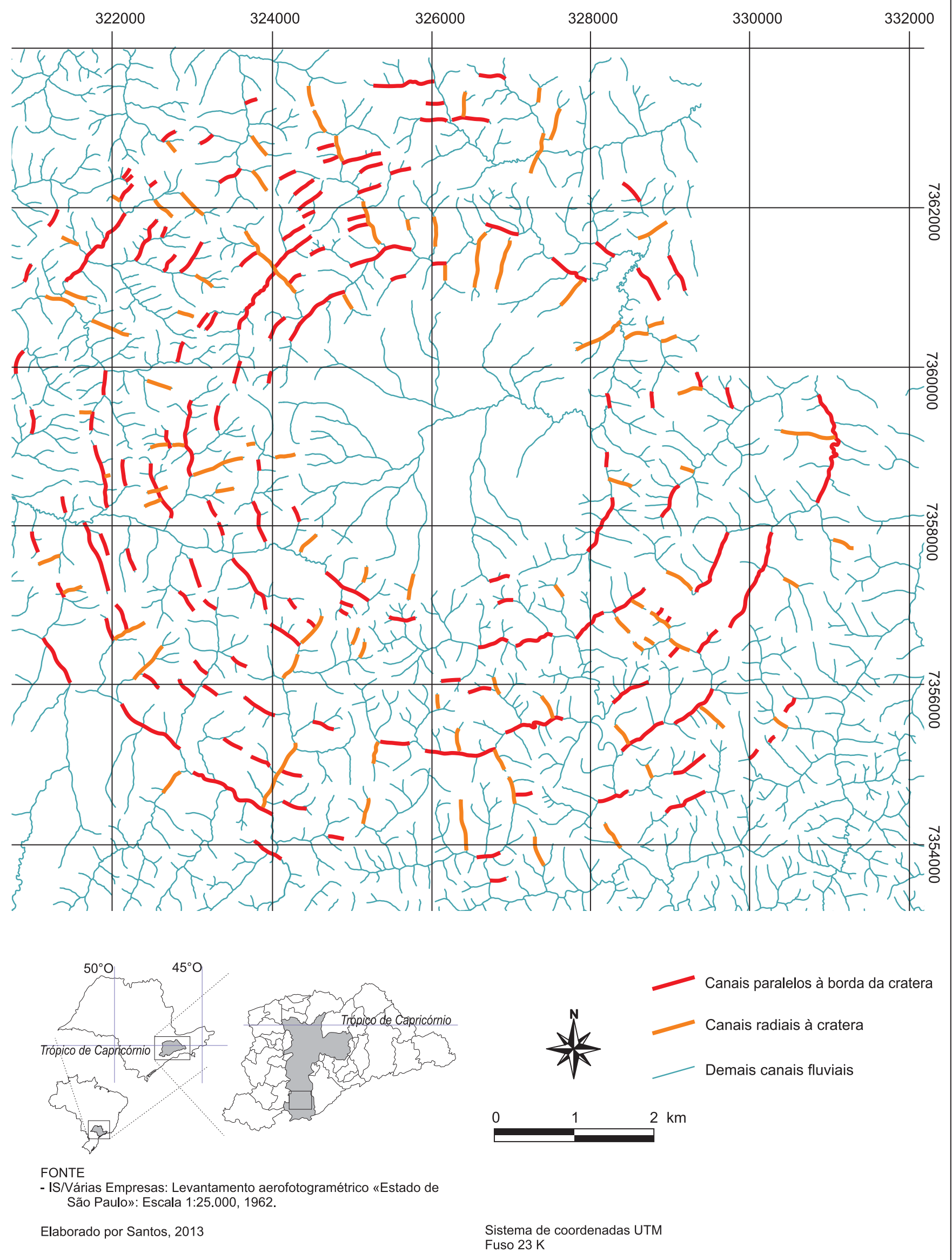
Mapa 18. COLÔNIA - SÃO PAULO, SP

Canais fluviais paralelos e radiais à borda da cratera, sem representação dos demais canais
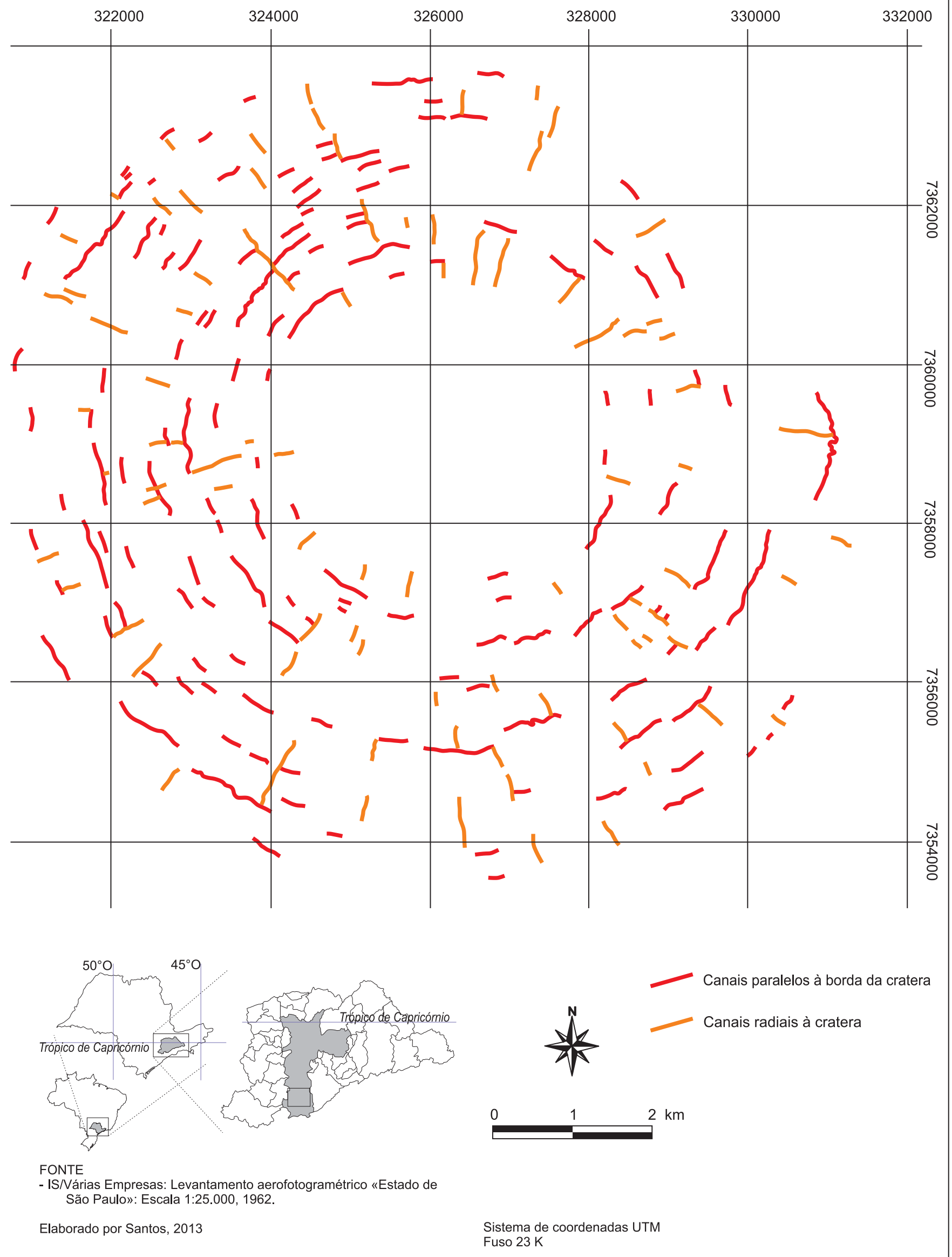

IS/Várias Empresas: Levantamento aerofotogramétrico «Estado de

São Paulo»: Escala 1:25.000, 1962.

Elaborado por Santos, 2013 

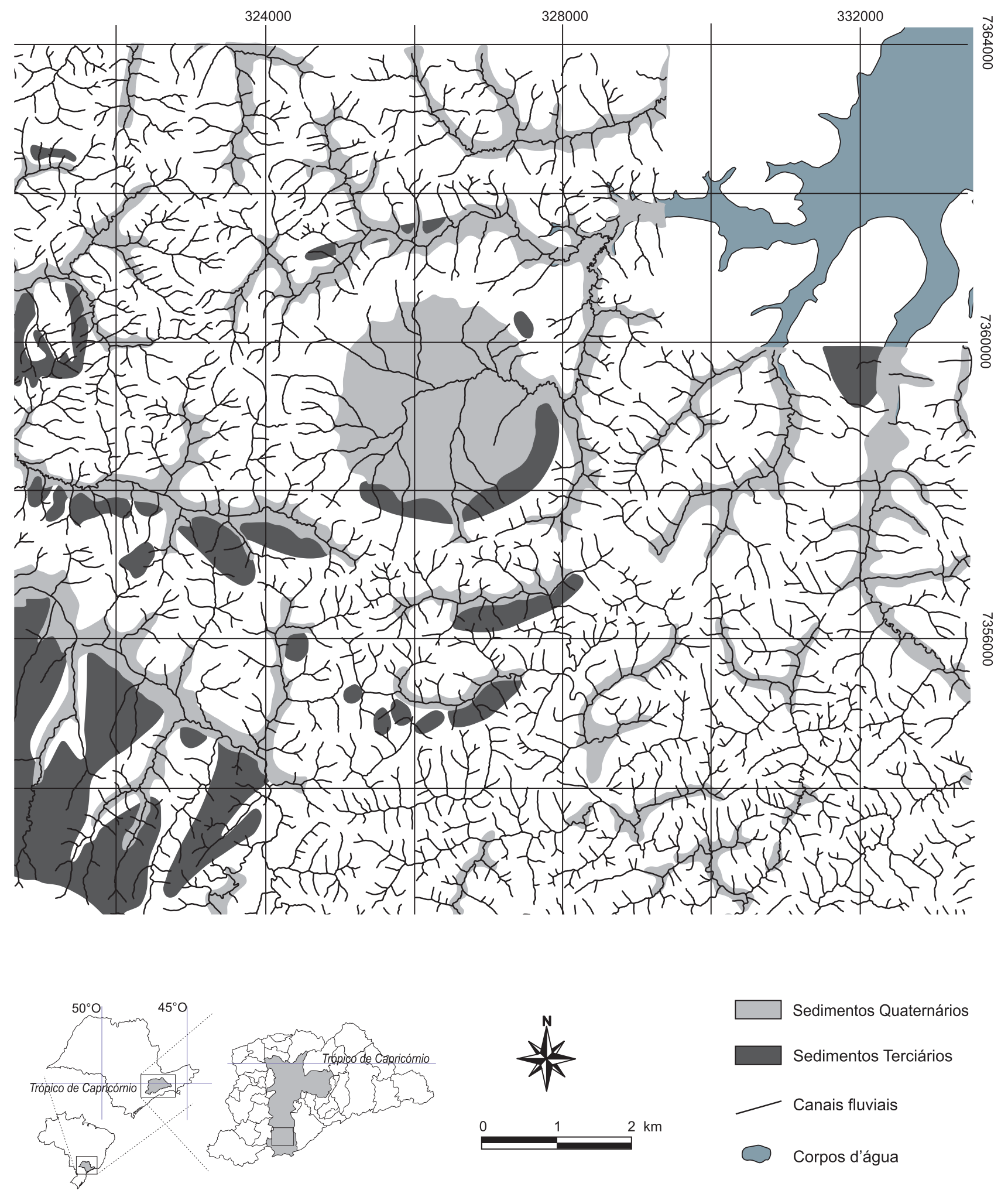

Sedimentos Quaternários

Sedimentos Terciários

Canais fluviais

FONTE

EMPLASA; Coutinho, J. M. Carta Geológica da Região Metropolitana de São Paulo. Escala 1:50.000, 198?

- IS/Várias Empresas: Levantamento aerofotogramétrico «Estado de São Paulo»: Escala 1:25.000, 1962 
Observa-se que a incisão dos canais fluviais promoveu remoção de grande parte dos sedimentos terciários no entorno da Bacia de São Paulo, conforme já mencionado por Ab'Sáber (1957). No Mapa 17, mostra-se a atual distribuição dos sedimentos terciários na área, os quais formaram um padrão grosso modo anelar, análogo ao da drenagem. A sul, sedimentos terciários dispõem-se em arco paralelo à cratera, o que pode constituir um fragmento de anel erodido.

É possível que essa disposição dos sedimentos reflita uma condição inicial, na qual sedimentos deformados logo após o impacto sustentariam altos e baixos topográficos, com a rede de drenagem se instalando e entalhando nas partes rebaixadas. Assim, os maiores canais podem ter preservado sua configuração espacial inicial, entalhando nos terrenos cristalinos, segundo um processo de superimposição. No entanto, é mais provável que o padrão anelar seja sustentado por uma rede de fraturas radiais e concêntricas presentes no embasamento cristalino até a atualidade.

Além da influência dada pela estrutura herdada do impacto, o desenvolvimento da drenagem teria sido influenciada também por atividade neotectônica, conforme a cronologia dos movimentos tectônicos recentes apresentada por Riccomini et al. (2004). Para o estudo do efeito da tectônica na evolução da drenagem, delimitaramse sub-bacias de quarta ordem, atendendo à necessidade de haver bacias em quantidade suficiente e com área significativa para as análises (Anexo 2).

Nelas, obtiveram-se os perfis longitudinais dos rios principais acrescidos do Índice SL (HACK, 1973) (Gráficos 11 a 25). A única exceção é a bacia 2, única a leste da cratera, na qual foram obtidos os perfis dois rios. Com o mesmo objetivo, também foram produzidos: carta de anomalias de drenagem (Mapa 20), perfis (Gráficos 26 a 39) e integrais hipsométricos (Mapa 21). A numeração das sub-bacias encontra-se no Anexo 2. 

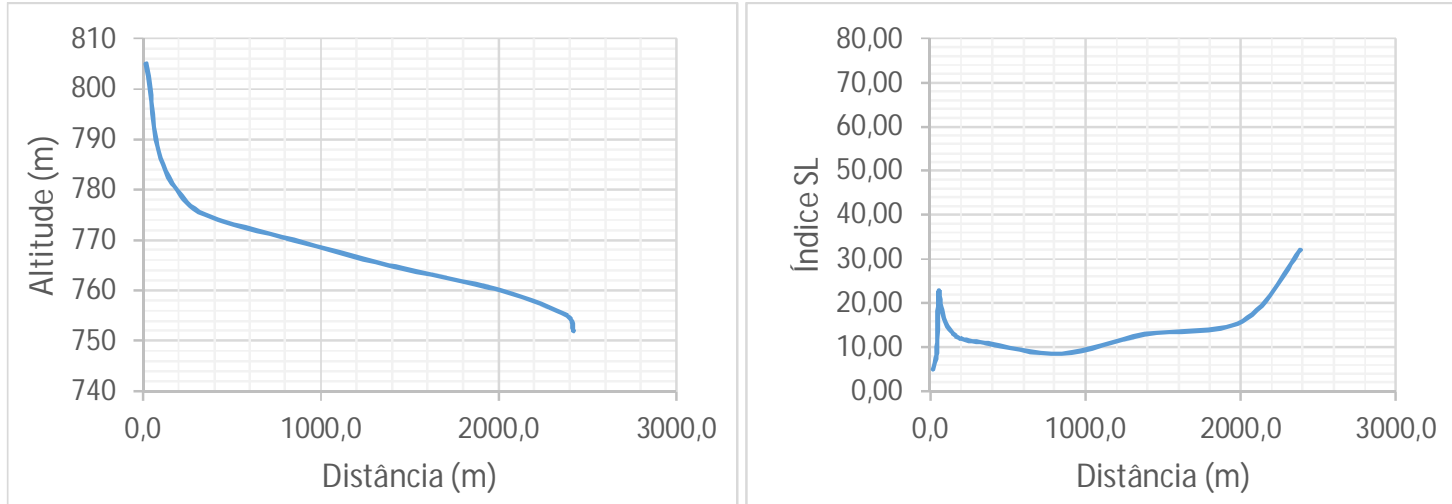

Gráfico 11 - Perfil longitudinal (esquerda) e Índice SL do Rio 1, conforme Anexo 2.
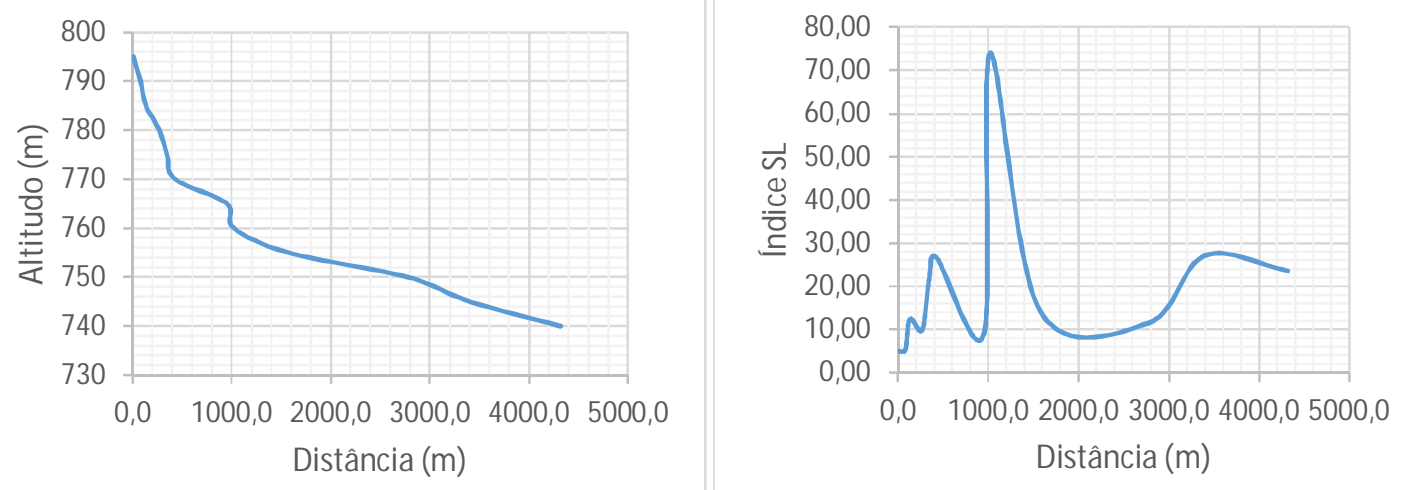

Gráfico 12 - Perfil longitudinal (esquerda) e Índice SL do Rio 2A, conforme Anexo 2.
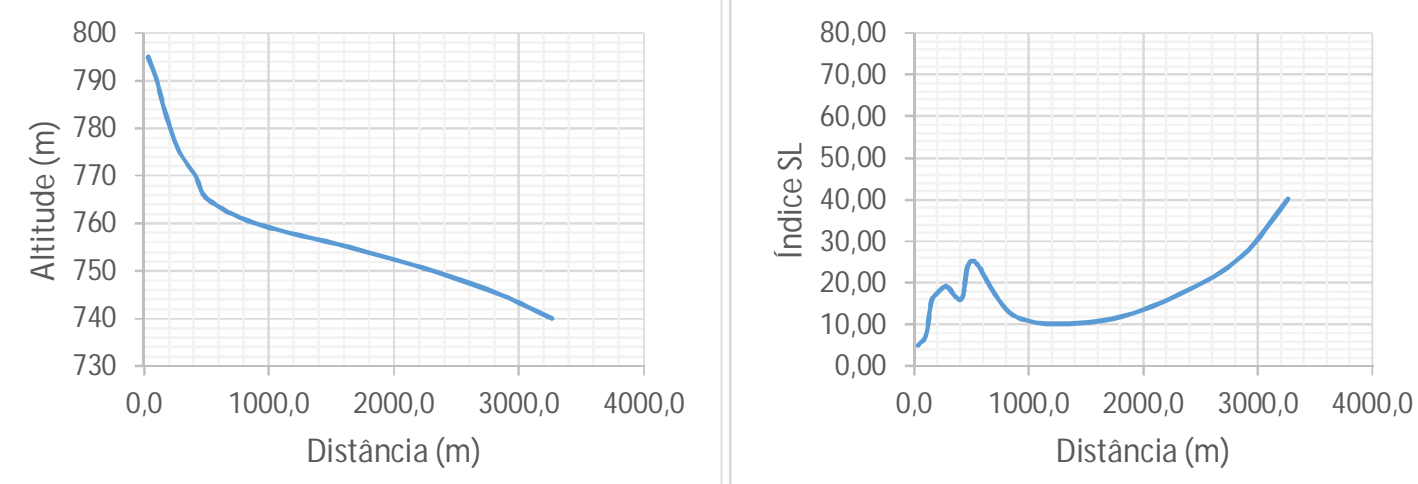

Gráfico 13 - Perfil longitudinal (esquerda) e Índice SL do Rio 2B, conforme Anexo 2. 

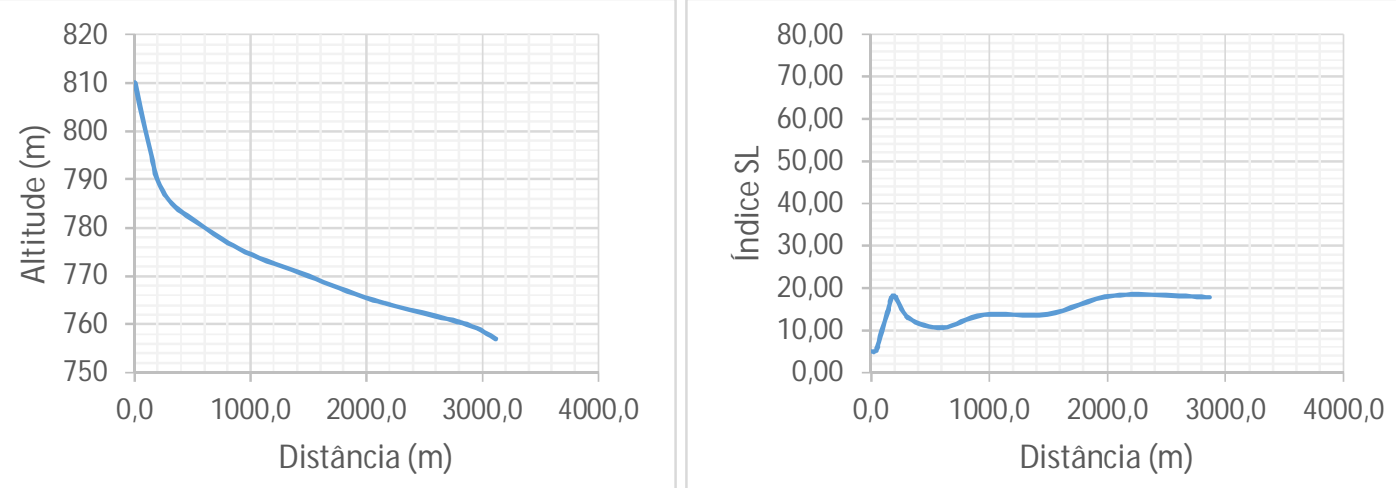

Gráfico 14 - Perfil longitudinal (esquerda) e Índice SL do Rio 3, conforme Anexo 2.
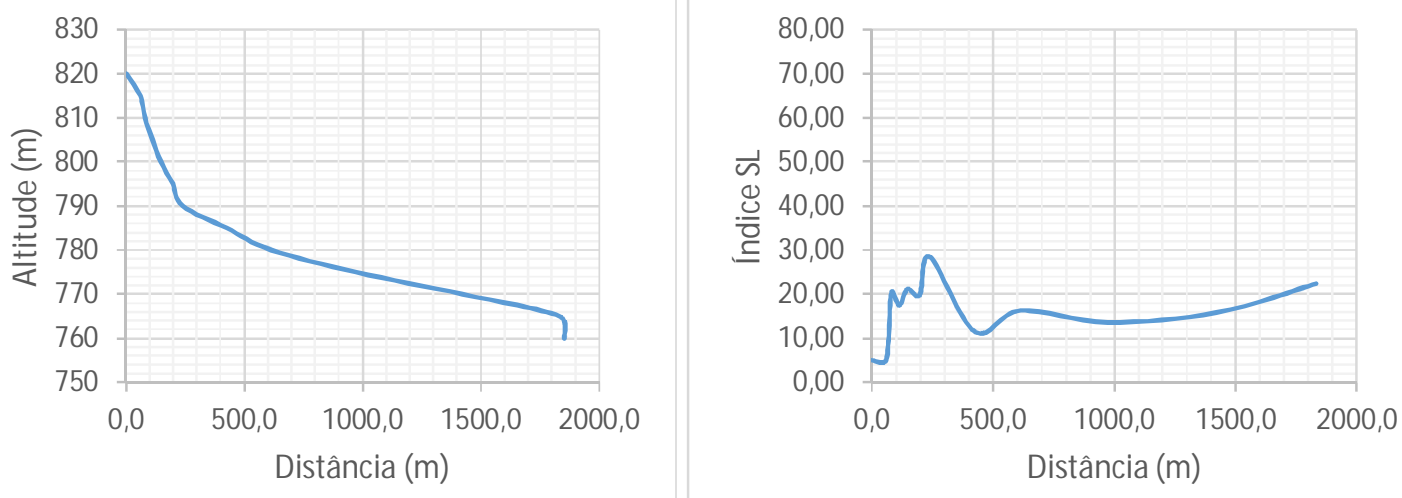

Gráfico 15 - Perfil longitudinal (esquerda) e Índice SL do Rio 4, conforme Anexo 2.
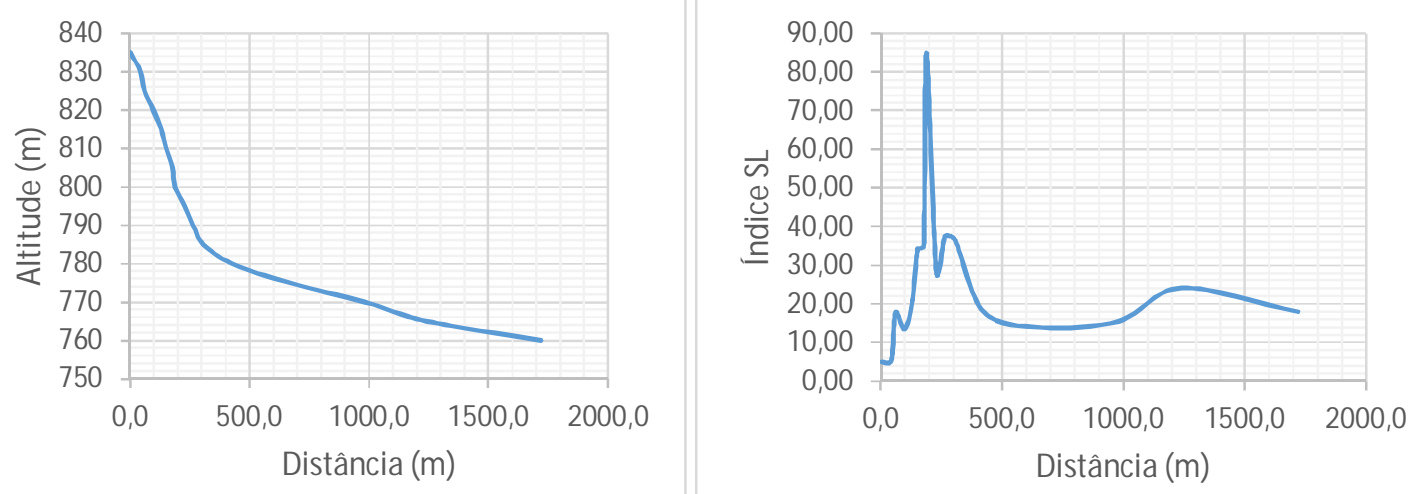

Gráfico 16 - Perfil longitudinal (esquerda) e Índice SL do Rio 5, conforme Anexo 2. 

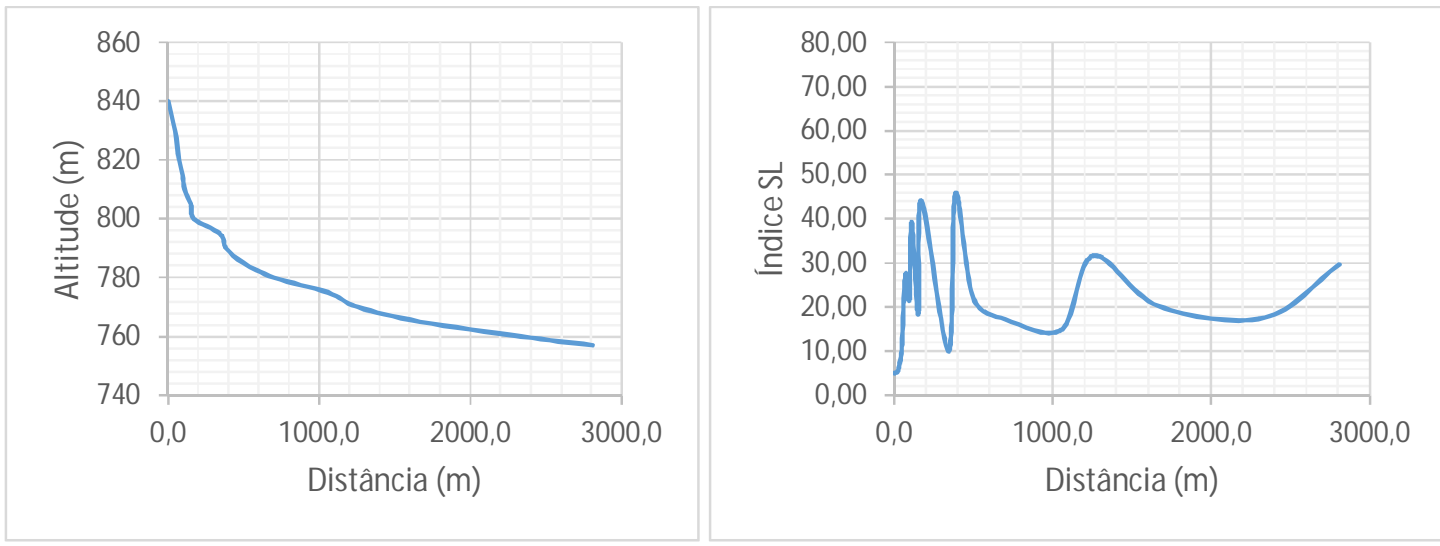

Gráfico 17 - Perfil longitudinal (esquerda) e Índice SL do Rio 6, conforme Anexo 2.

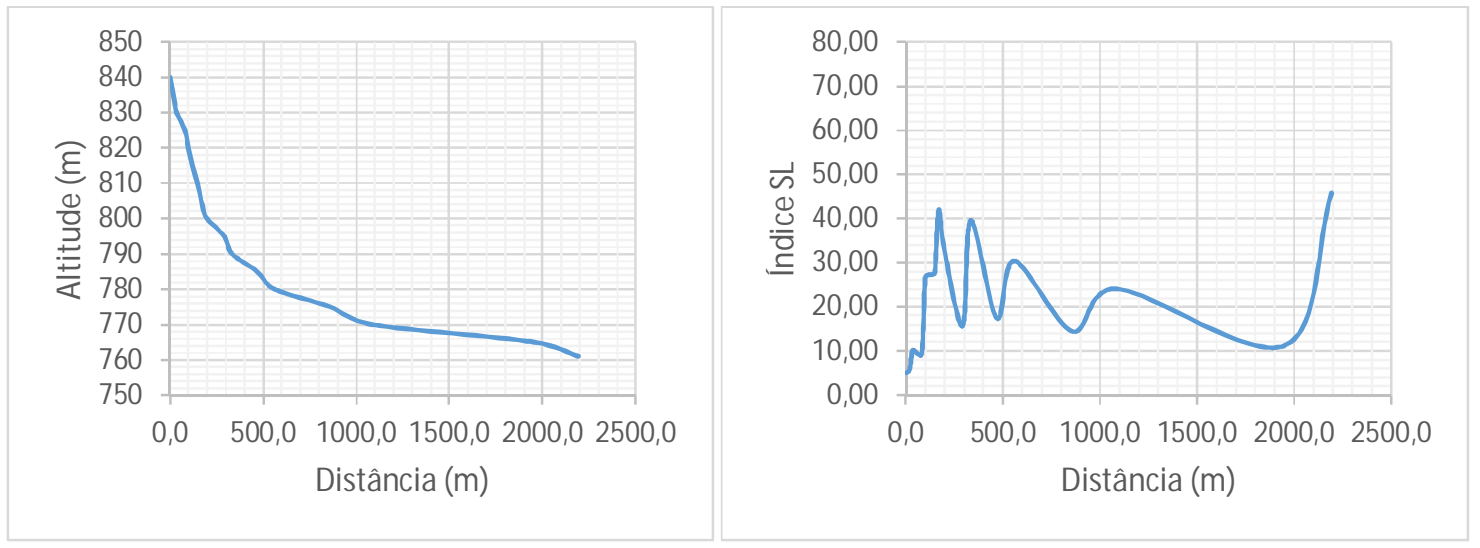

Gráfico 18 - Perfil longitudinal (esquerda) e Índice SL do Rio 7, conforme Anexo 2.
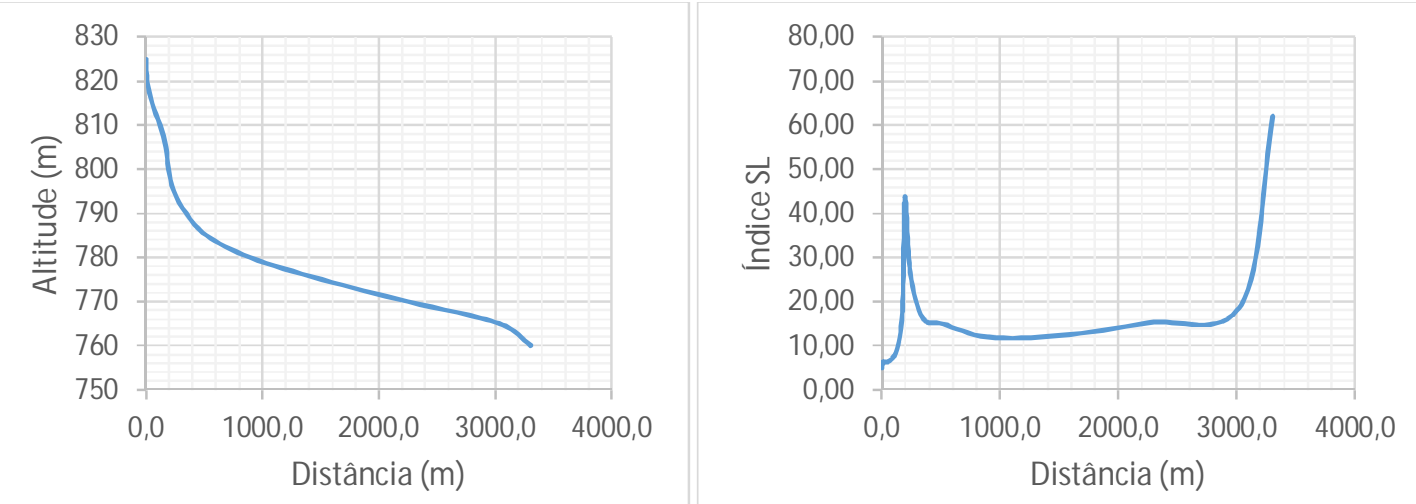

Gráfico 19 - Perfil longitudinal (esquerda) e Índice SL do Rio 8, conforme Anexo 2. 

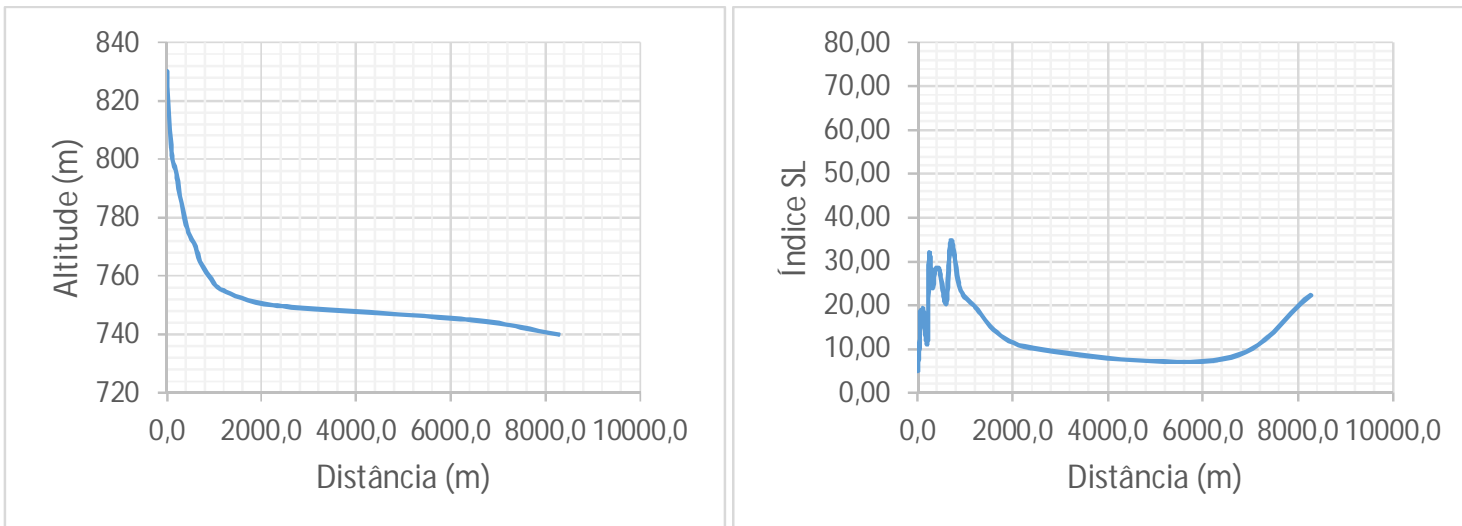

Gráfico 20 - Perfil longitudinal (esquerda) e Índice SL do Rio 9, conforme Anexo 2.
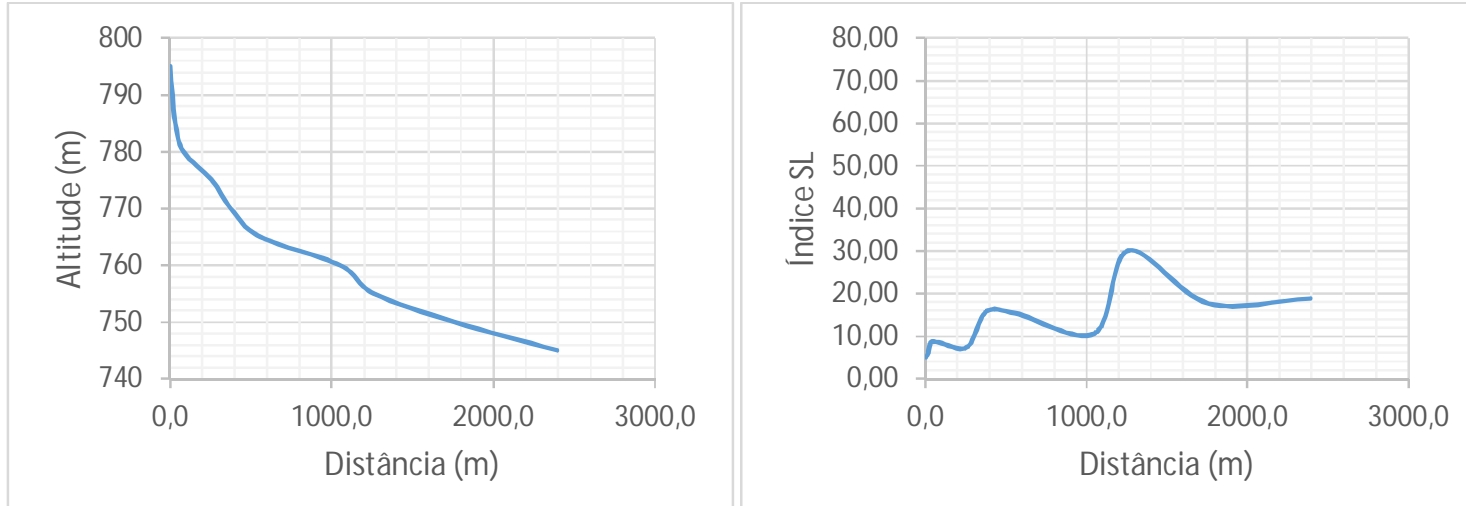

Gráfico 21 - Perfil longitudinal (esquerda) e Índice SL do Rio 10, conforme Anexo 2.
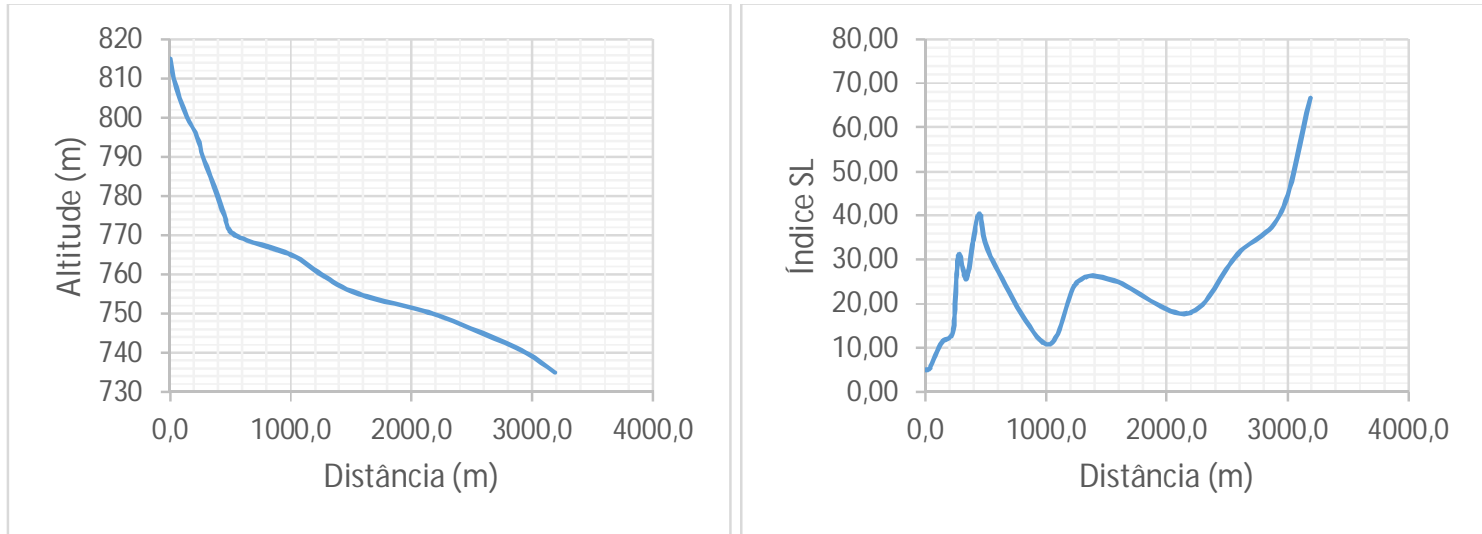

Gráfico 22 - Perfil longitudinal (esquerda) e Índice SL do Rio 11, conforme Anexo 2. 

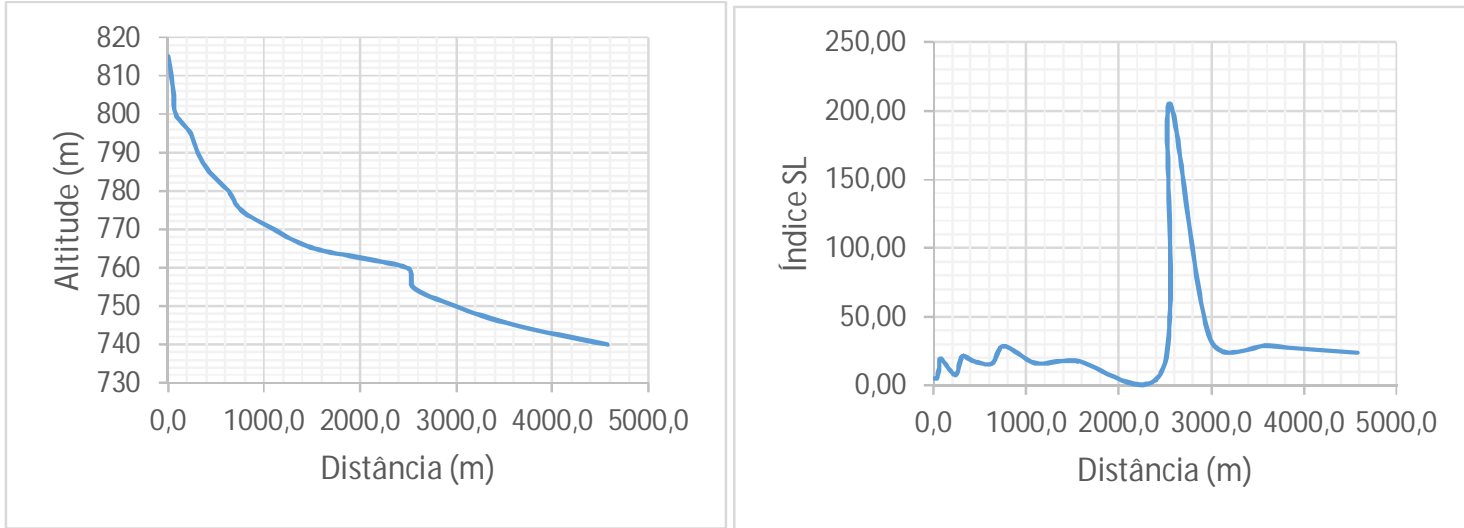

Gráfico 23 - Perfil longitudinal (esquerda) e Índice SL do Rio 12, conforme Anexo 2.
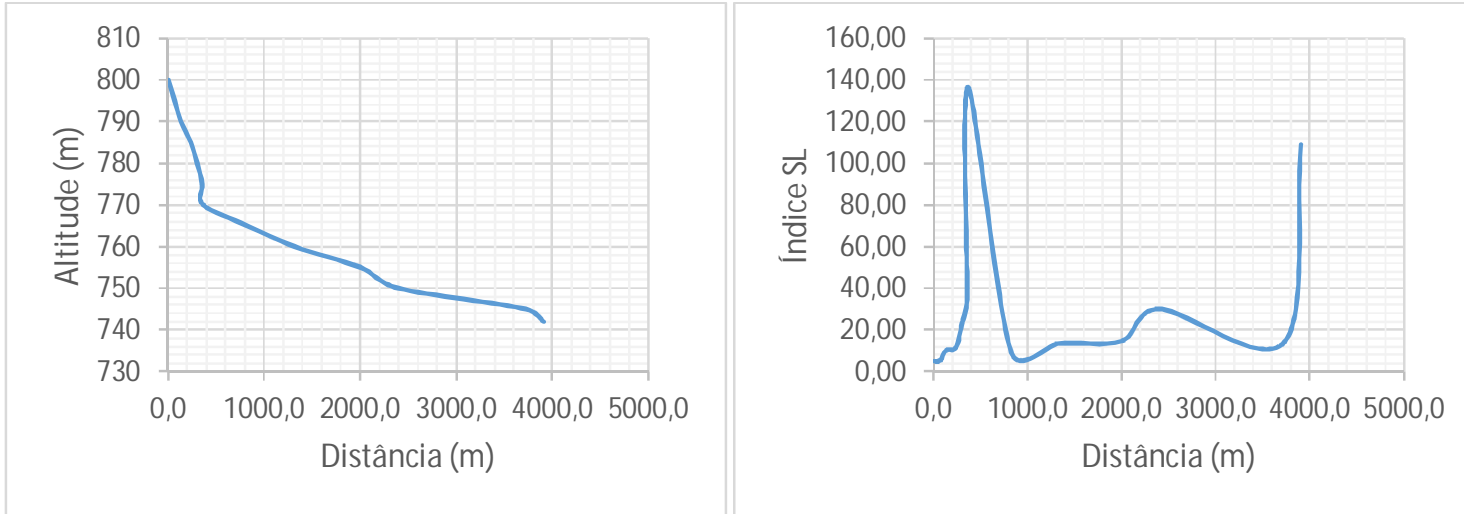

Gráfico 24 - Perfil longitudinal (esquerda) e Índice SL do Rio 13, conforme Anexo 2.
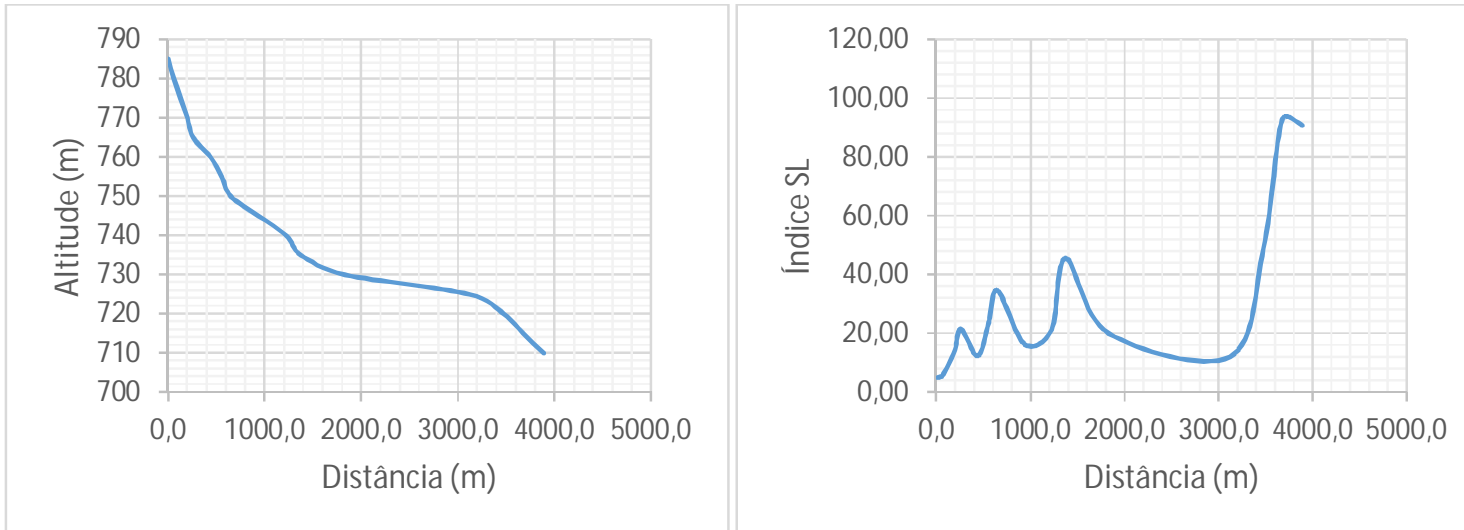

Gráfico 25 - Perfil longitudinal (esquerda) e Índice SL do Rio 14, conforme Anexo 2. 
Os perfis longitudinais e a aplicação do Índice SL revelaram knickpoints em sete das 14 bacias analisadas (rios 2A, 5, 6, 8, 10, 12 e 13).

O rio $2 \mathrm{~A}$, a leste da cratera, possui knickpoint em trecho de terceira ordem, na cota $765 \mathrm{~m}$, no qual apresenta importante inflexão, de $90^{\circ}$ para a direita, a partir do qual ajusta-se a um vale com nítido controle estrutural, retilíneo de direção nortenordeste.

O rio 5, a noroeste da cratera, possui knickpoint em trecho de segunda ordem, em seu alto curso, na cota de $790 \mathrm{~m}$, em área atravessada por vários lineamentos de direção leste-nordeste.

O rio 6, a oeste da cratera, possui knickpoint em trecho de segunda ordem, em seu alto curso, na cota de $790 \mathrm{~m}$ e relaciona-se com um lineamento topográfico de orientação norte-noroeste.

O rio 8, localizado na face externa do segmento sudoeste do Anel Colinoso da cratera, possui knickpoint em trecho de segunda ordem, na cota $800 \mathrm{~m}$, trecho no qual inflete para oeste-noroeste, ajustando-se a uma possível fratura concêntrica à cratera de Colônia, relacionada ao impacto que a formou.

O rio 10, pertencente à bacia do Embura, possui knickpoint em trecho de terceira ordem, na cota $760 \mathrm{~m}$, na metade do percurso entre sua nascente e a Planície do Rio Embura; sua presença provavelmente marca a incisão promovida pelo Rio Embura quando do abatimento de um bloco tectônico, delimitado por lineamentos de direção leste-nordeste.

O mesmo lineamento atravessa o rio 12, a sul da cratera, que possui knickpoint em trecho de quarta ordem, na cota $775 \mathrm{~m}$, onde ele inflete para sul, em uma curva de aproximadamente $90^{\circ}$ para a direita, na transição de terrenos mais elevados para mais baixos, na passagem do primeiro ao segundo vale concêntrico à cratera, a sul.

Por fim, o rio 13, localizado no segundo vale concêntrico a sul da cratera, possui knickpoint no trecho de transição de segunda para terceira ordem, na cota $770 \mathrm{~m}$, onde ele inflete para leste, descrevendo uma curva de aproximadamente $90^{\circ}$ para a esquerda no trecho em que ingressa no vale estruturalmente controlado.

Os knickpoints descritos não coincidem com contatos litológicos mapeados, exceto aqueles entre sedimentos e o embasamento cristalino. No entanto, a baixa 
precisão na delimitação de unidades rochosas no mapeamento geológico da área torna precária tal interpretação e não exclui o controle litológico de alguns deles.

O mapa de anomalias de drenagem mostra a distribuição espacial de knickpoints, de wind gaps e de inflexões de ângulo superior a 90ำ, relacionando-as às falhas e aos demais lineamentos identificados. Devido à exiguidade de falhas mapeadas, a maioria das estruturas é inferida a partir da análise de lineamentos.

Observa uma maior concentração de knickpoints à distância de $2.000 \mathrm{~m}$ da borda da cratera, tanto a norte quanto a sul. Provavelmente, eles se devem a uma combinação de falhamentos de origem tectônica no entorno da cratera, mas não se deve excluir a possibilidade de que sejam derivados de um degrau topográfico produzido na ocasião do impacto.

A grande concentração de knickpoints a sul da cratera, na bacia do Rio Capivari, soma-se à presença de inflexões e wind gaps, o que permite supor ocorrência de rearranjos de drenagem. Tais rearranjos teriam origem nos movimentos tectônicos mais recentes e na forte incisão dos canais fluviais, em uma bacia hidrográfica de amplo gradiente altimétrico.

Riccomini et al. (1991) fazem referência a um afloramento localizado a $1.000 \mathrm{~m}$ da borda sul da cratera, que evidenciaria uma zona de empurrão, de direção oestenoroeste e mergulho para norte-nordeste, na qual sedimentos argilosos e arenosos estariam tectonicamente imbricados com gnaisses pré-cambrianos do embasamento. Descrevem também uma família subvertical de juntas de direção leste-nordeste bem desenvolvidas nesses sedimentos e supõem compressão no eixo leste-nordeste e extensão no eixo norte-noroeste. Os autores consideram a possibilidade de se tratar de uma borda colapsada da cratera, mas afirmam que o padrão de deformação não discorda do evento transpressivo do Oligoceno ao Pleistoceno observado na área.

Independentemente da origem da zona de empurrão, ela possui forte relação com a distribuição dos knickpoints identificados, indicando que sua formação exerceu influência ao desenvolvimento do relevo e da drenagem ao sul da cratera, como observado no Mapa 20. 


\section{Anomalias de drenagem}

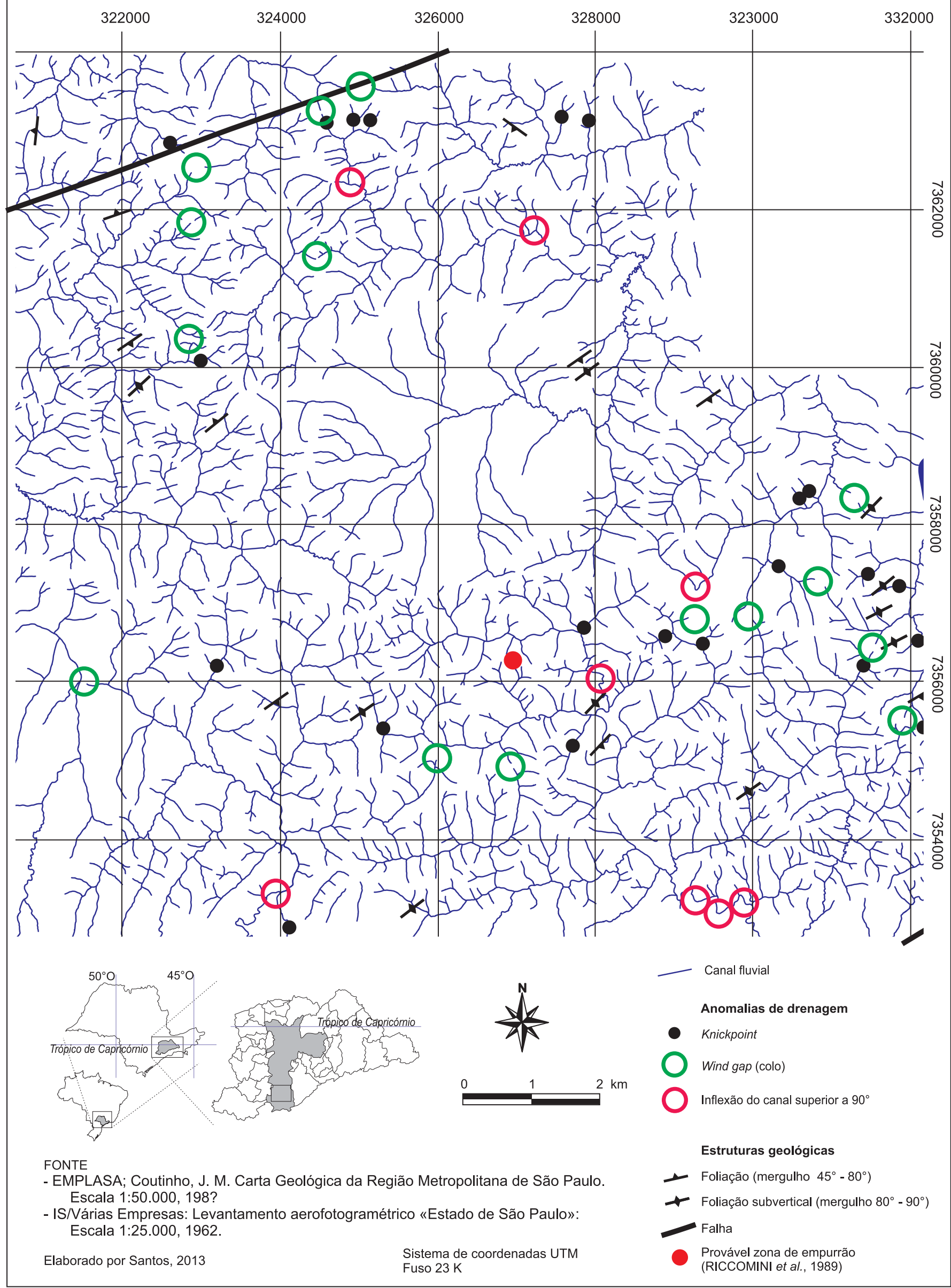



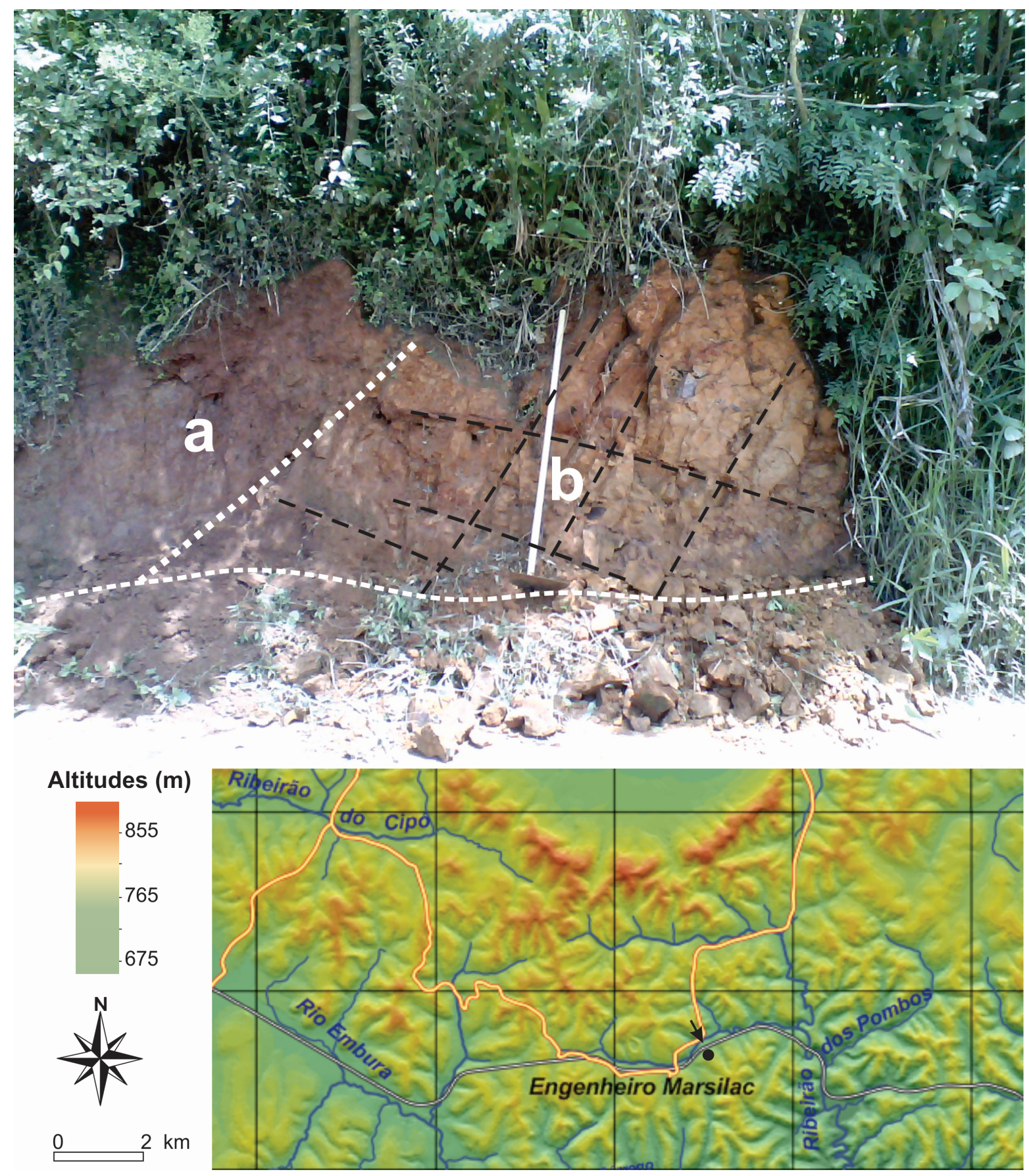

Foto 8 - Afloramento de arenito fraturado (b) sob material detrítico provavelmente transportado (a). Contato abrupto entre as unidades indica discordância erosiva. No mapa abaixo, localização do afloramento (indicada com um ponto) e ângulo da obtenção da imagem (indicada com a seta). Obtido por Santos, 2012.

Em campo, identificou-se um afloramento no qual um material argilo-arenoso sobrepõe-se a outro arenoso, por meio de contato abrupto. Identificou-se que o 
material arenoso é, na realidade, um arenito intemperizado, exibindo denso sistema de fraturas, de direção leste-nordeste, mergulho de aproximadamente $45^{\circ}$ para nortenoroeste e caimento de $10^{\circ}$ para oeste-sudoeste (Foto 8). Um segundo conjunto de fraturas, sobreposto a este, exibe mergulho de 60ำ para oeste e direção norte-sul. Da mesma forma que as fraturas descritas por Riccomini et al. (1991), essas também exibem conformidade com eventos tectônicos do Oligoceno ao Pleistoceno e podem ser correlacionadas com as anomalias de drenagem observadas.

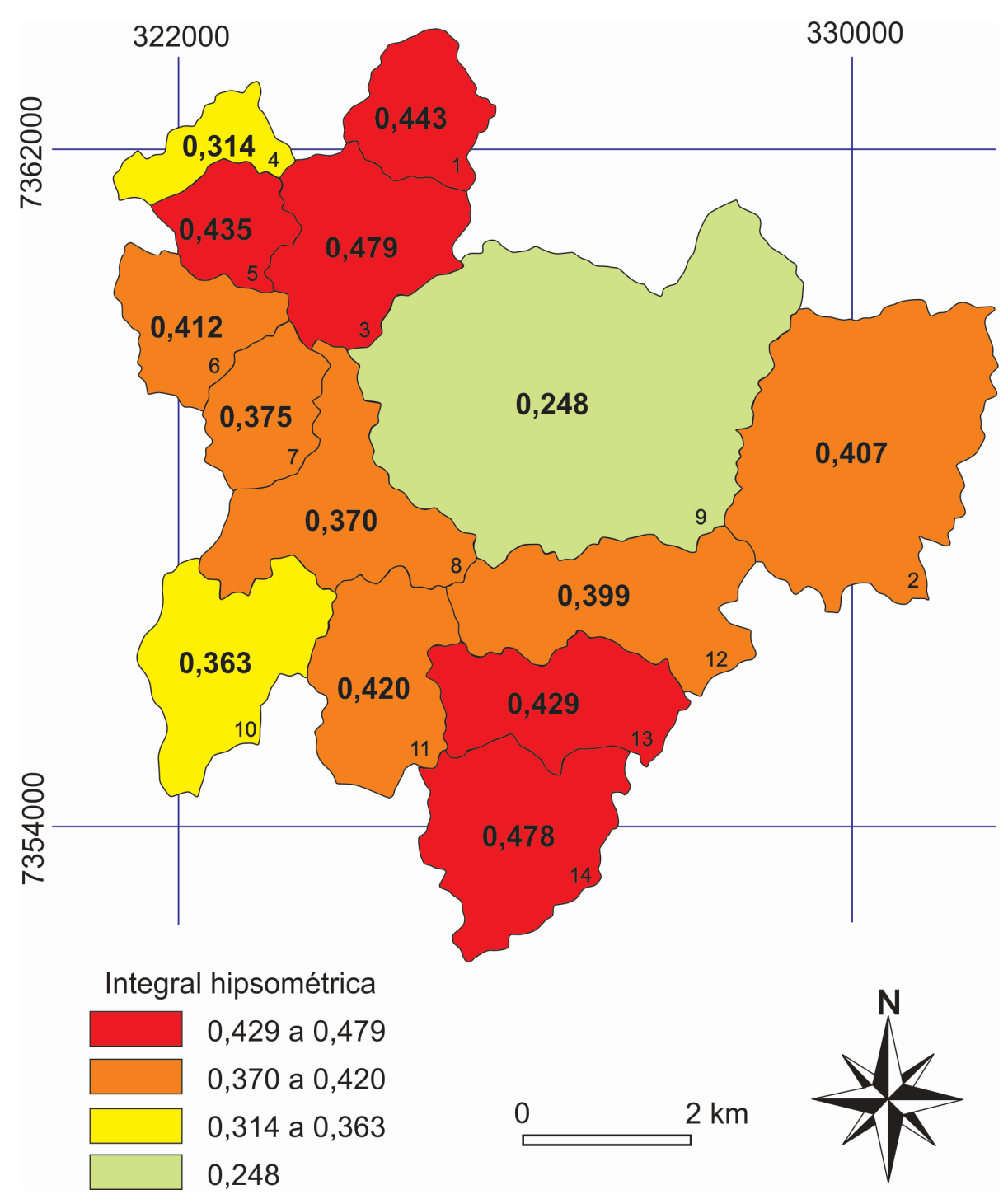

Mapa 21 - Integrais hipsométricas das sub-bacias de 4ª ordem que drenam a zona de formas concêntricas à cratera de Colônia, pertencentes às bacias dos rios: Embu-Guaçu, Jurubatuba e Capivari. Elaborado por Santos, 2013. 

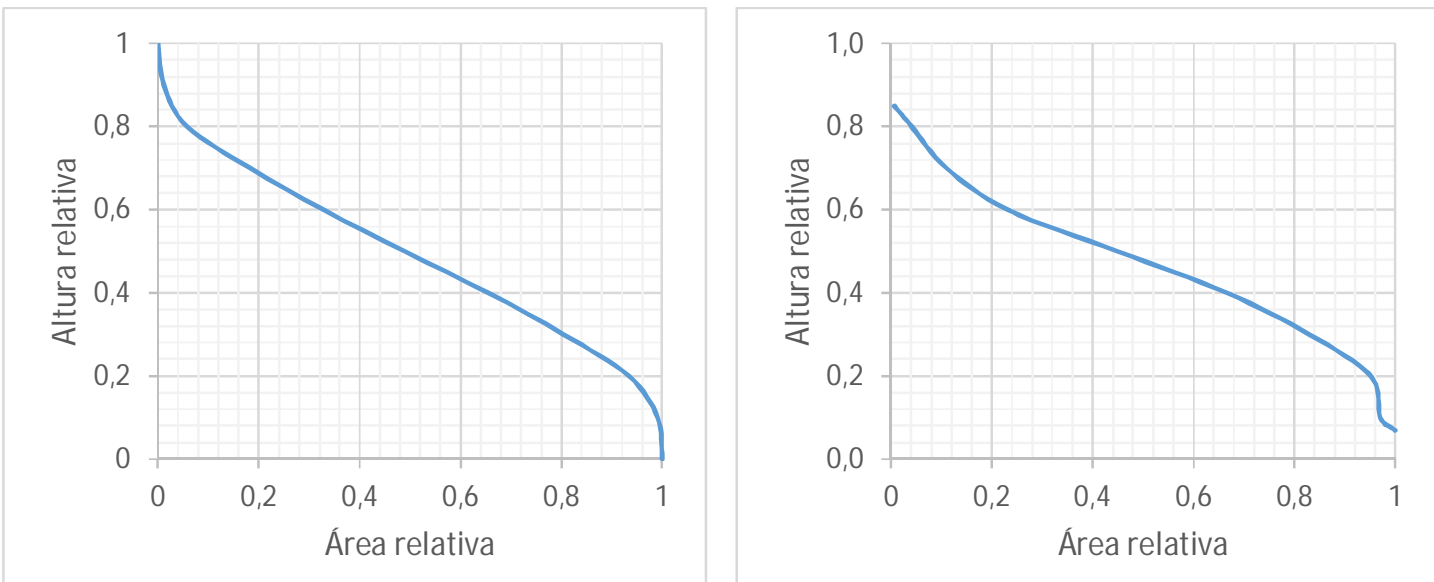

Gráfico 26 - Perfil hipsométrico da sub-bacia 1. Gráfico 27 - Perfil hipsométrico da sub-bacia 2.
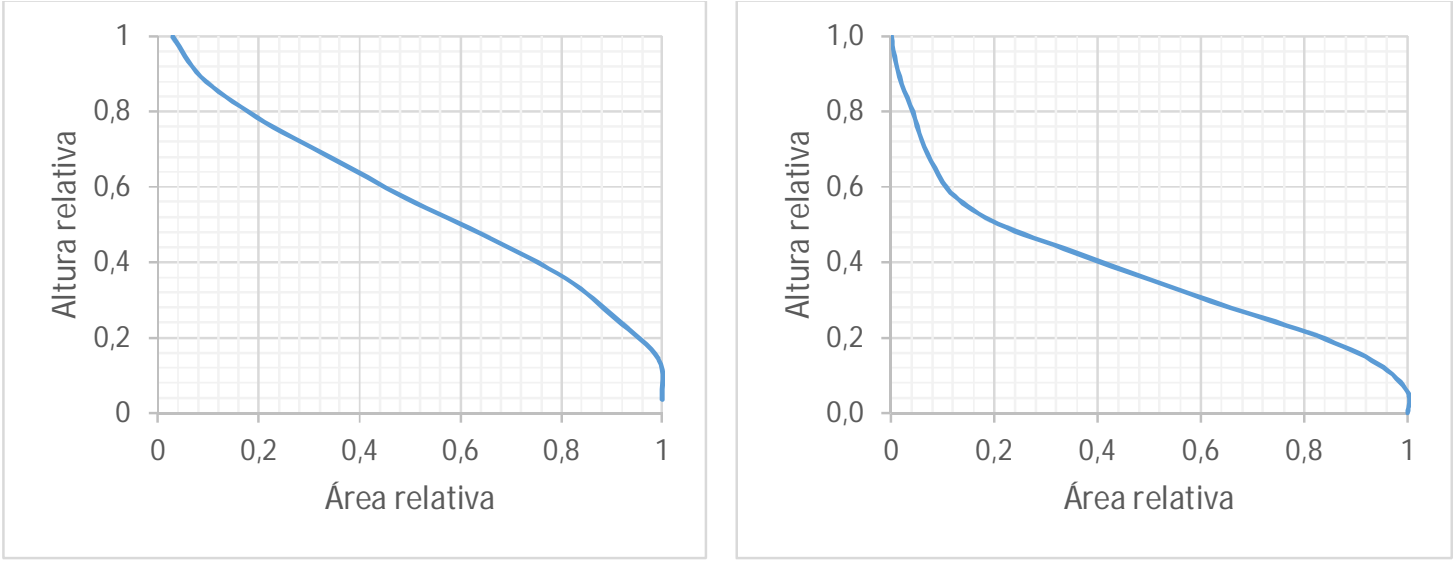

Gráfico 28 - Perfil hipsométrico da sub-bacia 3. Gráfico 29 - Perfil hipsométrico da sub-bacia 4.
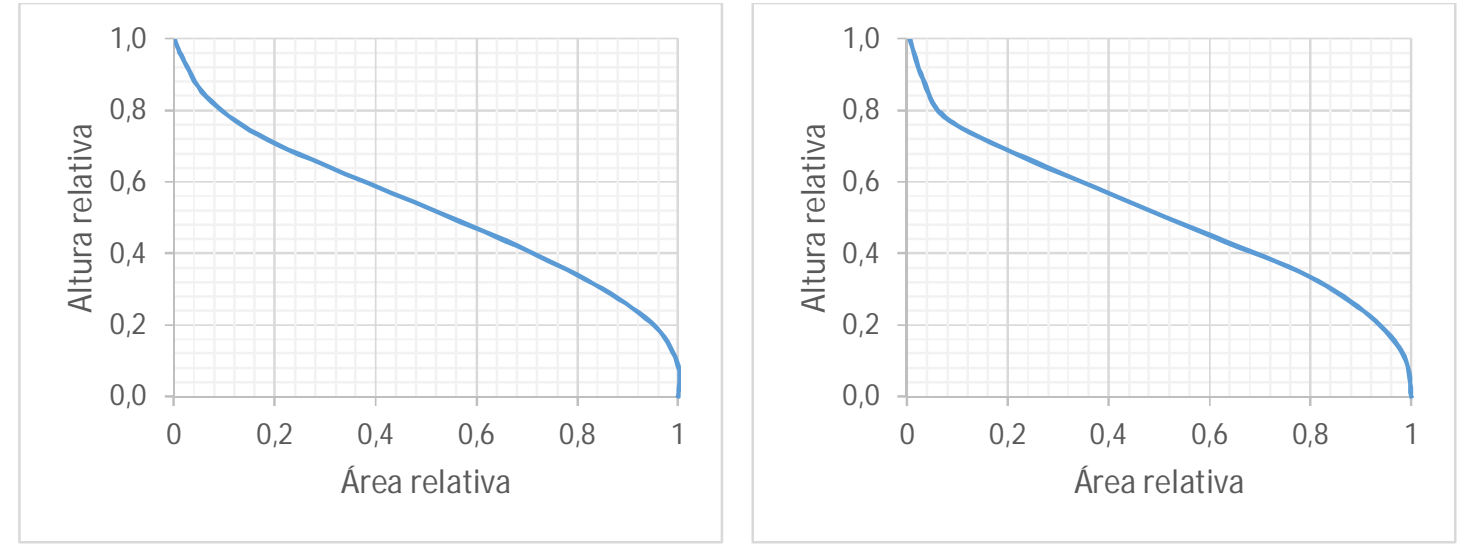

Gráfico 30 - Perfil hipsométrico da sub-bacia 5. Gráfico 31 - Perfil hipsométrico da sub-bacia 6. 

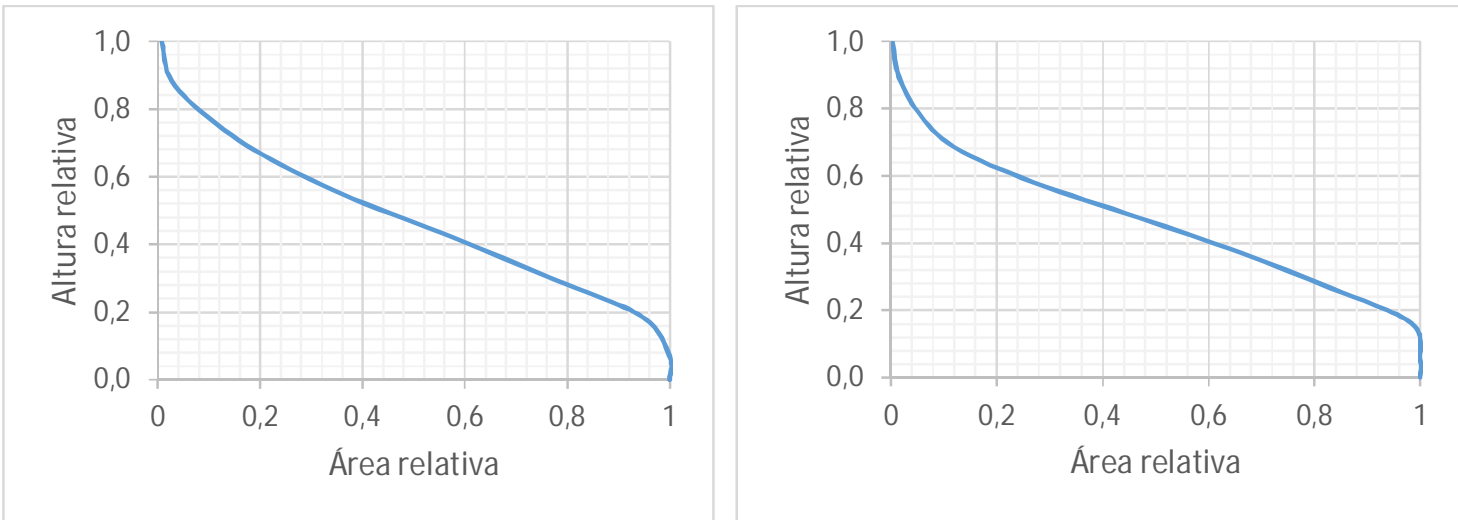

Gráfico 32 - Perfil hipsométrico da sub-bacia 7. Gráfico 33 - Perfil hipsométrico da sub-bacia 8.
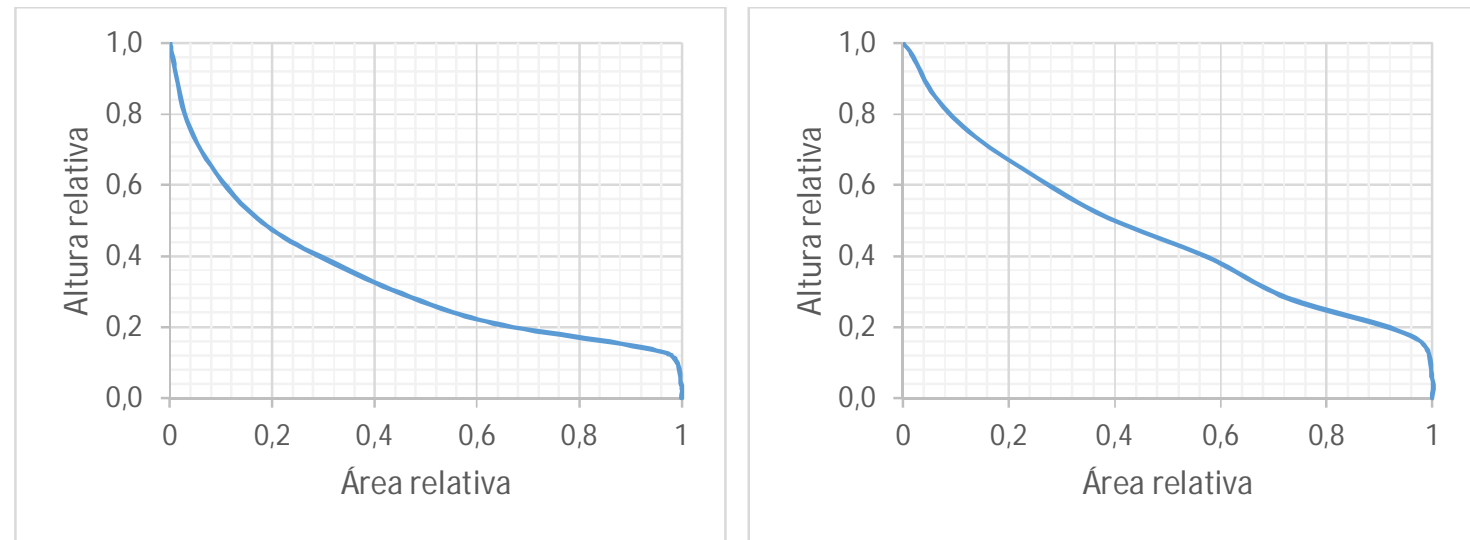

Gráfico 34 - Perfil hipsométrico da sub-bacia 9. Gráfico 35 - Perfil hipsométrico da sub-bacia 10.
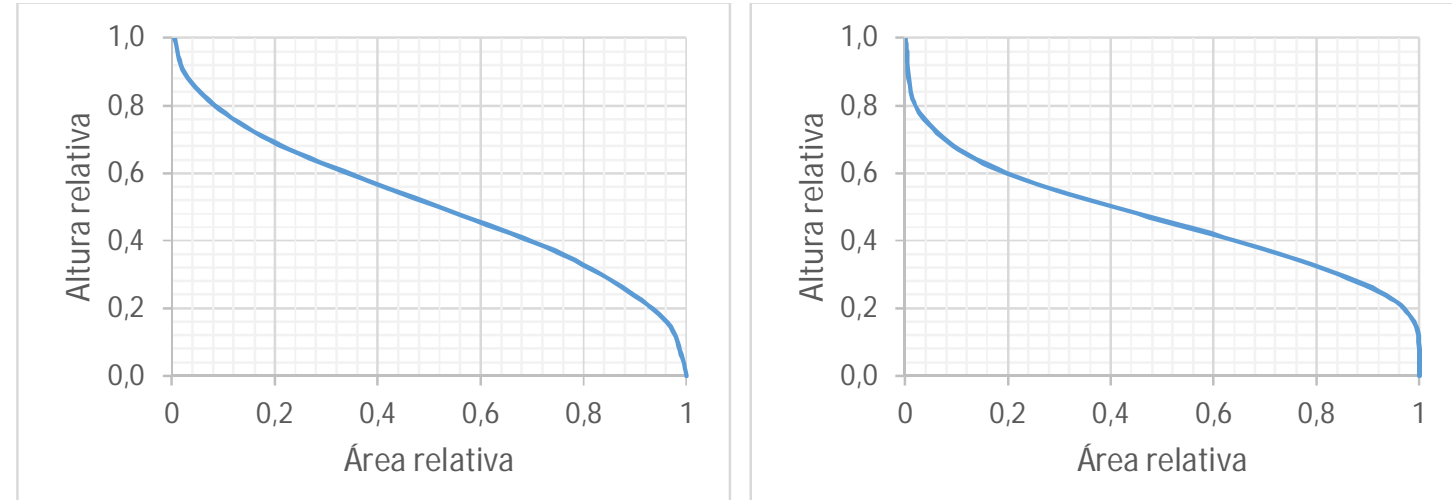

Gráfico 36 -Perfil hipsométrico da sub-bacia 11. Gráfico 37 - Perfil hipsométrico da sub-bacia 12. 

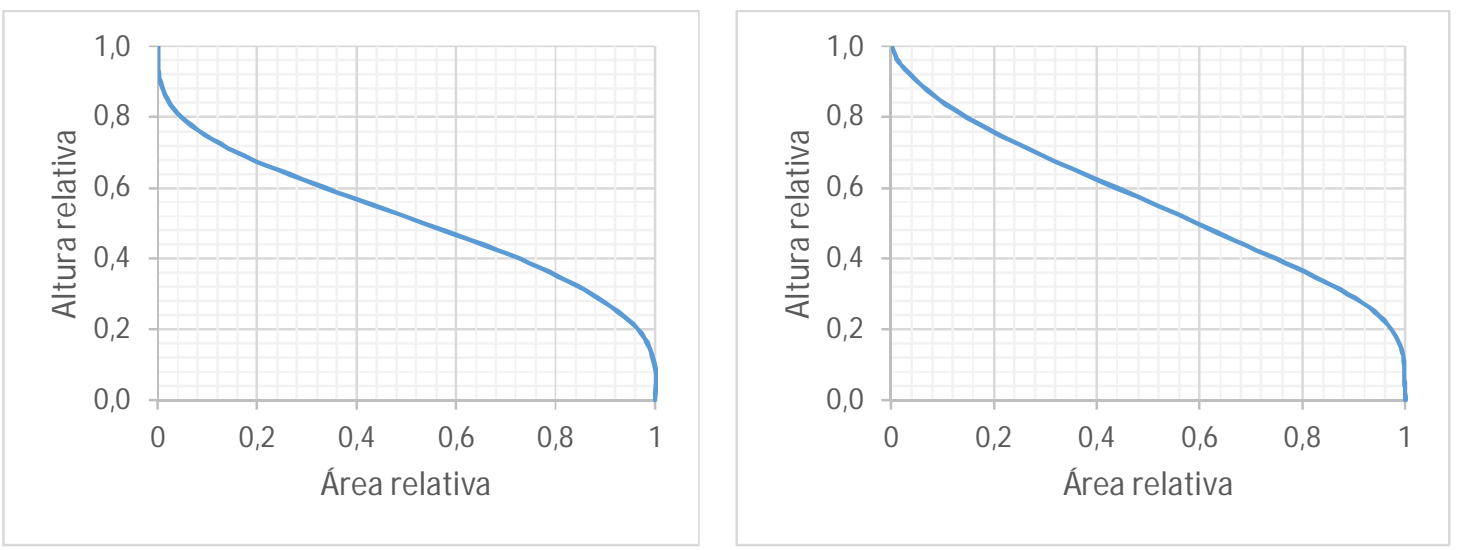

Gráfico 38 -Perfil hipsométrico da sub-bacia 13. Gráfico 39 -Perfil hipsométrico da sub-bacia 14.

A análise prossegue com a elaboração de integrais hipsométricas (Mapa 21) e perfis hipsométricos (Gráficos 26 a 39) das sub-bacias da região. Observam-se valores inferiores a 0,5 e perfis côncavos em todas as sub-bacias. Os menores valores são obtidos naquelas estabelecidas sobre terrenos sedimentares, como a 9, corresponde à área da cratera, e a 10 corresponde à área da bacia do Embura. Maiores valores de integral hipsométrica correlacionam-se com sub-bacias que possuem maior frequência de anomalias de drenagem.

Avalia-se, por fim, a variação de densidade de drenagem por sub-bacia, apresentada no Mapa 22. Observam-se redes de drenagem menos densas nas subbacias que possuem parcela significativa da superfície recoberta por sedimentos (bacias 2, 9, 10 e 11). Já as maiores densidades (bacias 1, 4, 5, 6, 7, 13) são associadas à presença de anomalias de drenagem. Há correlação entre bacias com maior densidade e maiores integrais hipsométricas de tal modo que os relevos mais dissecados na área são explicáveis por movimentações recentes de falhamentos que atravessam a área.

Com base nos dados apresentados, propõe-se que o desenvolvimento da drenagem anelar e do relevo concêntrico no entorno da cratera de Colônia teve condicionamento estrutural. Esse condicionamento teria dupla natureza, sendo função das estruturas herdadas do impacto, produzindo lineamentos radiais e concêntricos à cratera; e das estruturas herdadas de tectônica de longo prazo ou mesmo remobilizadas pela tectônica recente, produzindo lineamentos nas direções sulsudeste e leste-nordeste, predominantemente. 


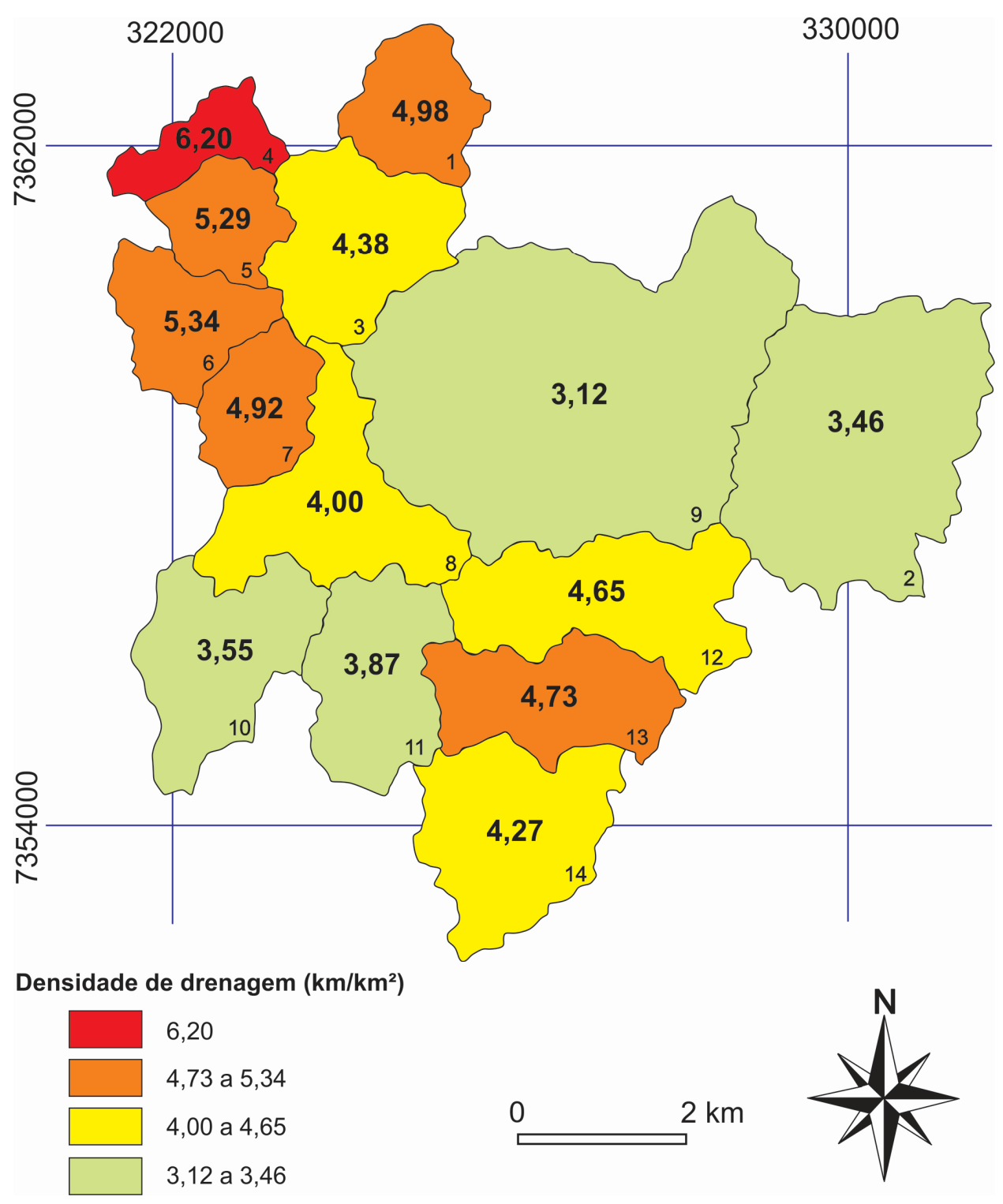

Mapa 22 - Densidades de drenagem das sub-bacias de $4^{\text {a }}$ ordem que drenam a zona de formas concêntricas à cratera de Colônia, pertencentes às bacias dos rios: Embu-Guaçu, Jurubatuba e Capivari. Elaborado por Santos, 2013. 


\subsection{DESENVOLVIMENTO DA DRENAGEM E DO RELEVO NO INTERIOR DA CRATERA DE COLÔNIA}

Observou-se que a drenagem no interior da cratera de Colônia possui padrão radial centrípeto e exutório a leste. O ribeirão Vermelho e seus tributários formam uma bacia de quarta ordem, com longos canais de primeira ordem que fluem pelas vertentes internas do anel colinoso. Essa drenagem contribuiu para a dissecação da cratera, como é observável no modelo tridimensional (Figura 23).

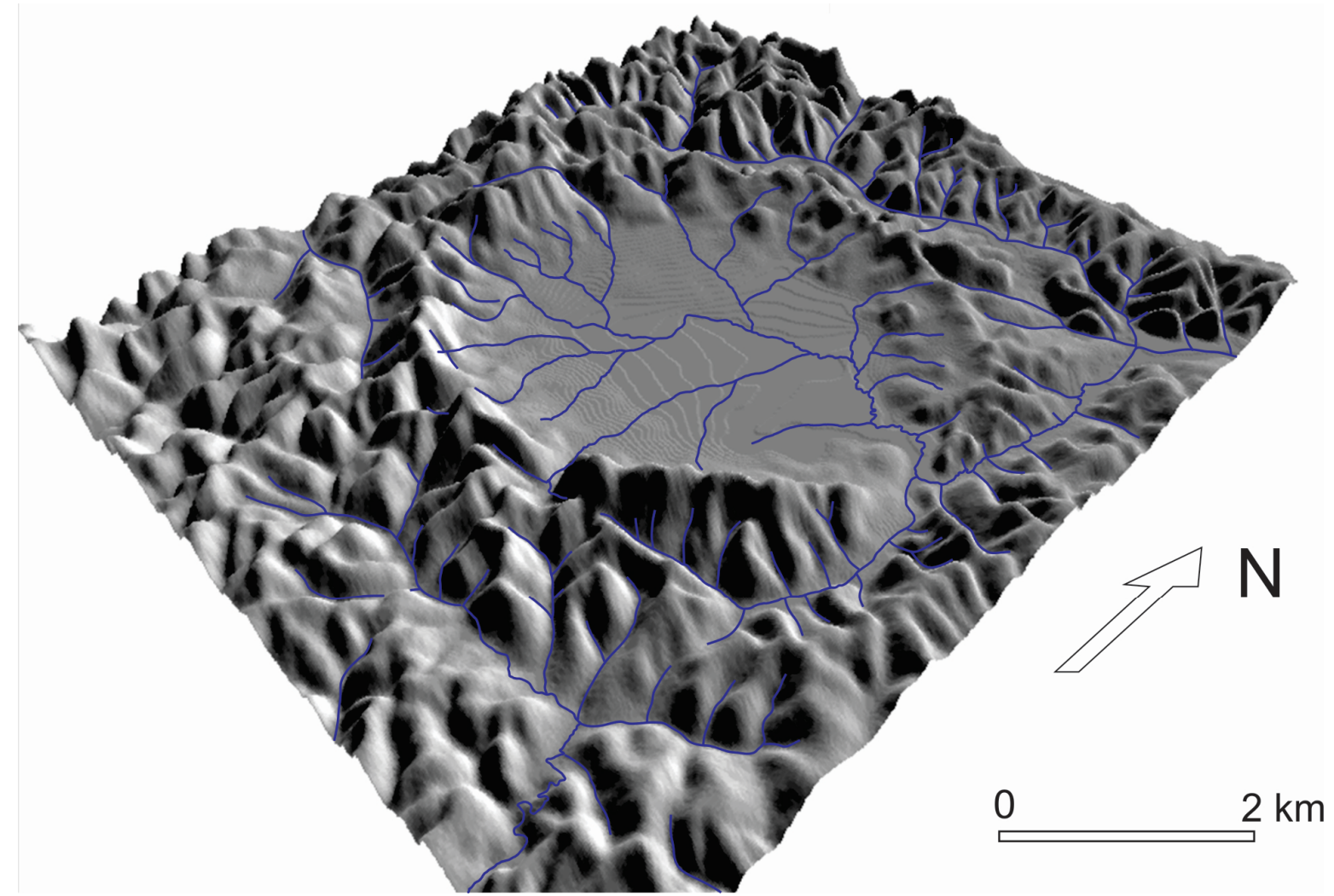

Figura 23 - Modelo tridimensional da cratera de Colônia, obtido por análise de MDE de escala 1:10.000. Observar dissecação das bordas da cratera, realizada pelos cursos d'água que atravessam o anel colinoso. Exagero vertical de 3 x. Elaborada por Santos, 2013.

As dimensões originais estimadas e atuais mensuradas da cratera são exibidas na Figura 24. Segundo cálculos realizados por Riccomini et al. (1991), a diferença original entre o topo da crista e a base do pacote sedimentar seria de $900 \mathrm{~m}$, enquanto que a espessura atual do pacote sedimentar seria de $436 \mathrm{~m}$. Esses valores partem do 
pressuposto de que a relação profundidade-diâmetro da cratera de Colônia é concordante com a média das demais, conforme obtido empiricamente por Grieve e Robertson (1979). Dados geofísicos mais atuais, apresentados por Riccomini et al. (2011) apontam, porém, uma profundidade de $280 \mathrm{~m}$ do pacote sedimentar, mostrando que a cratera é mais rasa que o esperado.

A altura inicial da crista da cratera deveria ser superior a $300 \mathrm{~m}$ em relação à superfície do entorno, enquanto que atualmente sua altura máxima em relação ao entorno é de $150 \mathrm{~m}$. Já a superfície da depressão central, preenchida por sedimentos, teve sua altitude progressivamente aumentada ao longo do tempo, o que compreende uma tendência de nivelamento da estrutura pelos processos denudacionais

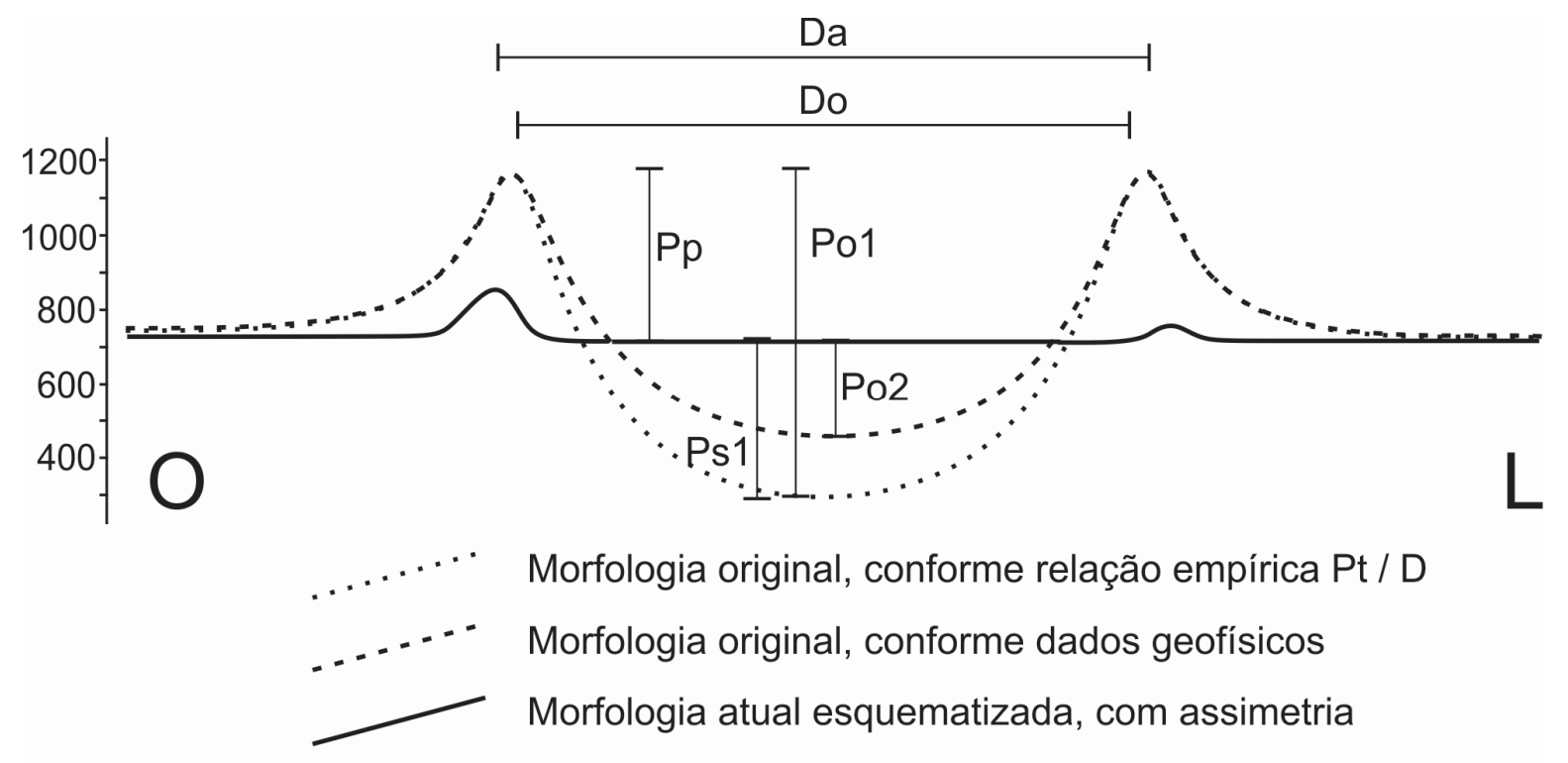

Figura 24 - Dimensões originais e atuais da Cratera de Colônia, conforme: relação empírica profundidade-diâmetro obtida por Grieve e Robertson (1979) e aplicada à cratera por Riccomini et al. (1991), dados geofísicos de profundidade do pacote sedimentar apresentados por Riccomini et al. (2011) e topografia atual. As dimensões originais representadas ignoram quaisquer diferenças altimétricas entre os lados opostos do anel colinoso. As medidas no diagrama são: $\mathrm{Da}$ (diâmetro atual) = $3.600 \mathrm{~m}$; Do (diâmetro original) = ?; Pp (profundidade aparente) $=464 \mathrm{~m}$; Po1 (profundidade original, conforme relação empírica Pt / D) =900 m; Po2 (profundidade original, conforme dados geofísicos) = $280 \mathrm{~m}$; Ps1 (profundidade original do pacote sedimentar, conforme relação empírica Pt / D) = $436 \mathrm{~m}$. Elaborado por Santos, 2013. 
Riccomini et al. (1991) notaram que a crista é mais rebaixada a leste que a oeste, sugerindo obliquidade do impacto para explicar a assimetria. A conclusão dos autores concorda com os estudos experimentais realizados por Gault e Wedekind (1978) e tem como pressuposto a manutenção da assimetria no processo de denudação da cratera. No entanto, as assimetrias altimétricas em crateras de impacto também são explicáveis por diferenças na litologia do alvo ou pela velocidade diferencial da erosão nas diferentes partes da estrutura de impacto (SCHULTZ e ANDERSON, 1996).

A litologia da área ainda não recebeu um mapeamento de detalhe, mas o material cartográfico disponível indica a existência de micaxistos sustentando todos os setores do anel soerguido, com exceção do segmento meridional, sustentado por gnaisses. Nos trabalhos de campo realizados neste estudo, identificaram-se micaxistos no entorno da cratera. Os dados atualmente disponíveis sobre o embasamento litológico da região sugerem não haver algum contraste que explique essa diferenciação. Deste modo, restam as hipóteses da obliquidade ou de velocidade diferencial da erosão.

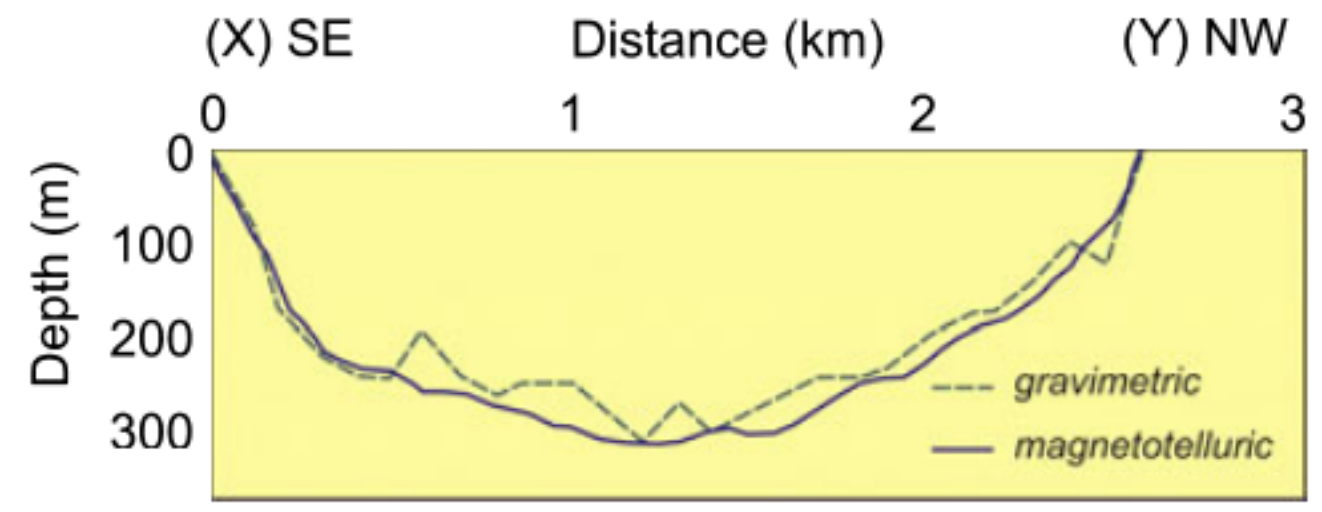

Figura 25 - Seção sudeste-noroeste da estrutura de Colônia, baseada em dados gravimétricos e áudio-magnetotelúricos obtidos por Motta e Flexor (1991) e Masero e Fontes (1991, 1992), respectivamente. Extraída de Riccomini et al., 2011.

Estudos geofísicos (Figura 22 e Figura 25) mostram assimetria no contato entre sedimentos que preenchem a cratera e o embasamento cristalino, com a parte mais profunda deslocada para sudeste em relação ao centro. A partir disso, supõe-se que o bólido teve proveniência de sudeste. Tal interpretação choca-se com a de Riccomini 
et al. (1991) de impacto de bólido proveniente de nordeste, baseada em dados da topografia.

A razão eixo maior / eixo menor da cratera, de 1,035, alongada no eixo lesteoeste, é pequena demais para fornecer alguma informação a respeito da orientação da trajetória do bólido. A alta circularidade da cratera indica que o ângulo de trajetória do bólido foi superior a $30^{\circ}$ em relação à superfície, conforme estudos de Gault e Wedekind (1978).

Não há boa correspondência entre o modelado superficial da cratera e a forma do contato entre seu pacote sedimentar e o embasamento cristalino (Figura 26). Se a forma atual da cratera refletisse um trabalho erosivo constante em todos os segmentos da crista, seus níveis seriam mais elevados a noroeste e mais rebaixados a sudeste, o que não se observa.

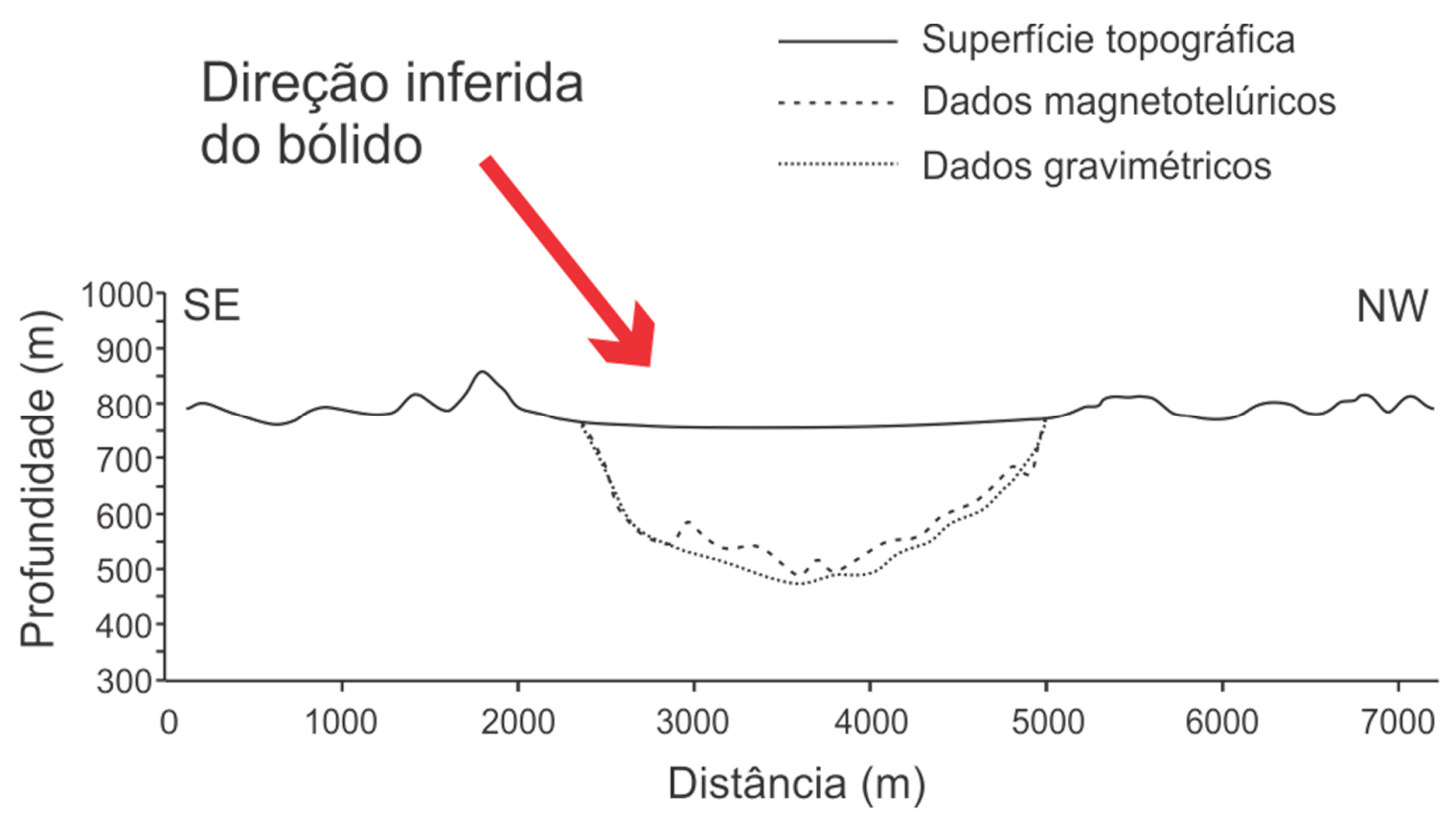

Figura 26 - Perfil topográfico da cratera de Colônia, acrescido de dados magnetotelúricos e gravimétricos apresentados por Riccomini et al. (2001). Direção inferida do bólido, inferida pelos autores citados. Organizado por Santos, 2013.

Nota-se, com base nos dados apresentados, que a obliquidade do impacto não explica a assimetria atual da cratera. Das três hipóteses que explicam crateras de 
impacto assimétricas, resta a da velocidade diferencial da erosão. Para testar essa hipótese, realizam-se observações a respeito do desenvolvimento da drenagem nas bacias hidrográficas da área.

A cratera é cercada por três bacias hidrográficas, dos rios: Jurubatuba, EmbuGuaçu e Capivari. Os tributários desses três rios principais contribuem para a dissecação da superfície da cratera.

Observa-se que assimetria na crista da cratera correlaciona-se com os níveis altimétricos do entorno, mais baixos a leste que a oeste, em escala regional (Mapa 8, Mapa 9). O mesmo fator que levou ao rebaixamento maior das superfícies a leste pode também ter provocado maior rebaixamento da crista da cratera a leste.

A análise dos perfis longitudinais dos rios Jurubatuba e Embu-Guaçu (Figura 27), cujos tributários dissecam a cratera respectivamente a leste e a oeste, mostra que suas nascentes estão praticamente no mesmo nível. No entanto, na proximidade da cratera, o nível do Jurubatuba é mais rebaixado. Isto porque, conforme Leopold et al. (1964, p. 415), se dois rios que cortam uma nascem na mesma altitude em área litologicamente uniforme, o mais distante aprofunda mais seu nível, na busca de encontrar seu perfil de equilíbrio. A região estudada não é exatamente uniforme no ponto de vista litológico, mas não apresenta também forte contraste na composição das unidades rochosas, sendo o quartzo, o feldspato e a mica os minerais mais abundantes em todas elas (COUTINHO, 1980).

A análise de curvas e integrais hipsométricos das bacias do Jurubatuba, EmbuGuaçu (a montante da confluência do Embu-Mirim, sub-bacia que drena terras mais distantes a norte) e Capivari (Figura 28), mostra que a primeira possui integral hipsométrica $(0,28)$, menor que a da segunda $(0,31)$ e ambas apresentam curva de perfil côncavo. Isto significa que o Embu-Guaçu e seus tributários têm maior potencial para dissecação, enquanto que os cursos d'água da bacia do Jurubatuba já realizam grande parte desse trabalho. 


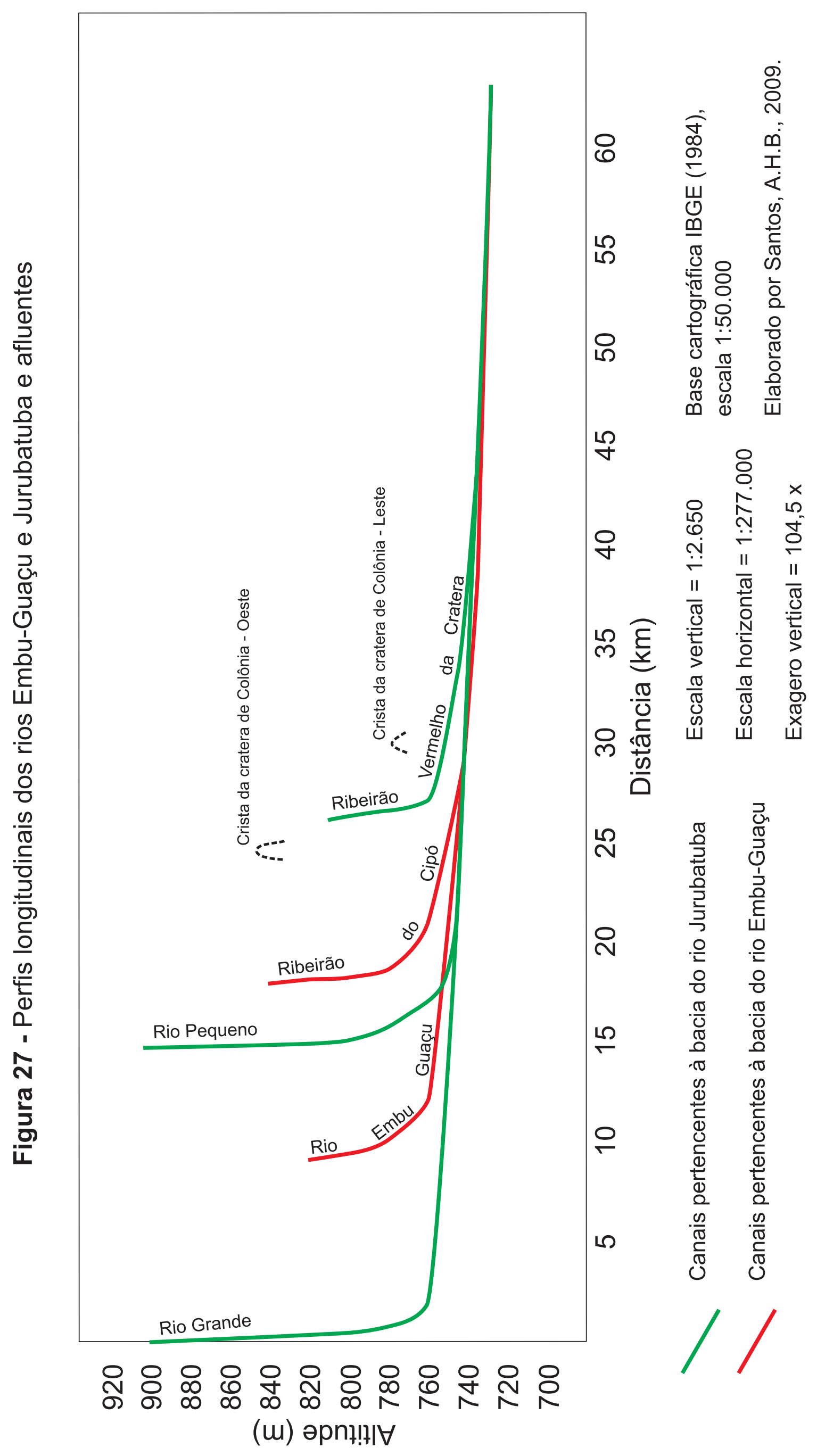



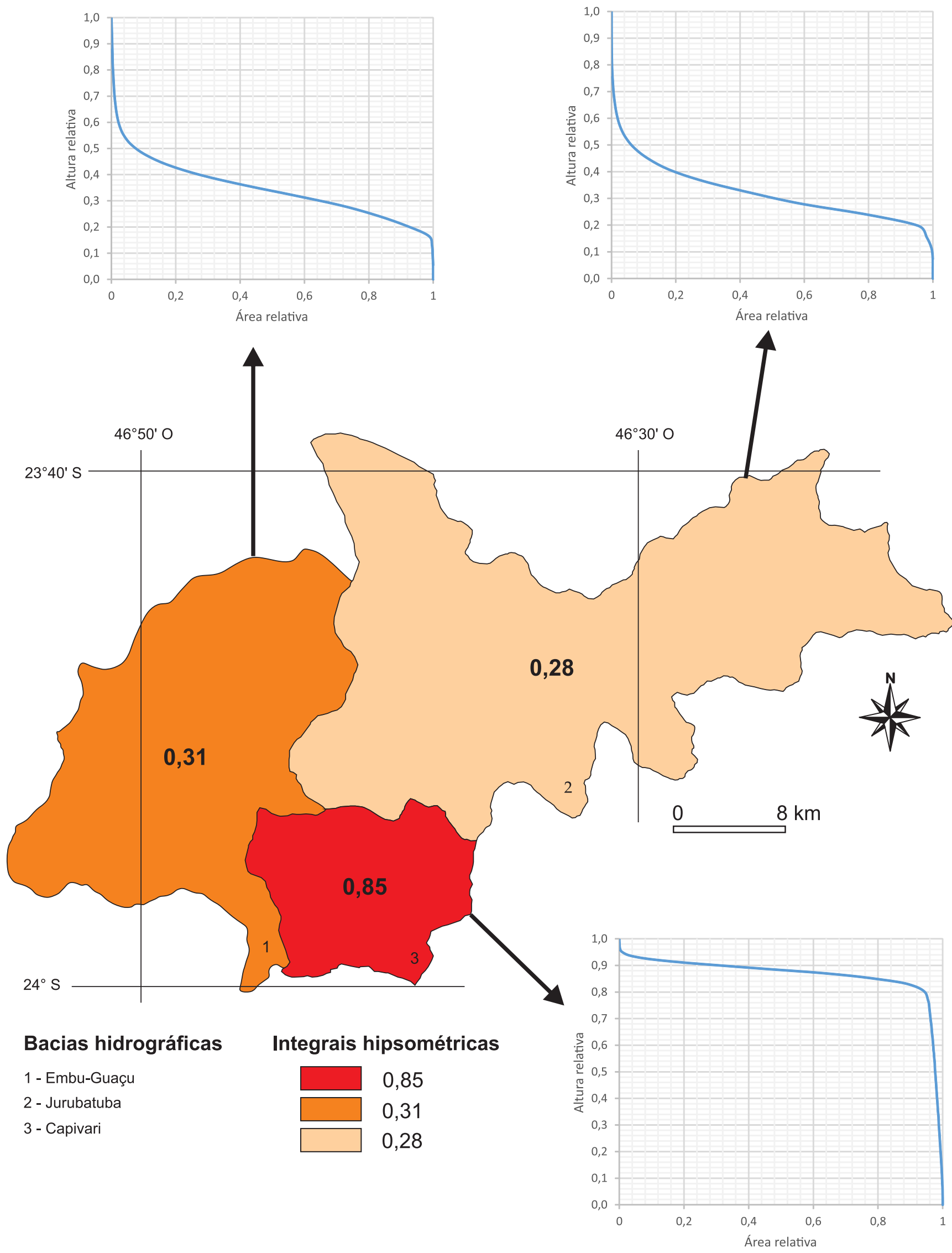

Figura 28 - Curvas e integrais hipsométricas das bacias dos rios Embu-Guaçu, Jurubatuba e Capivari. Elaborado por Santos, 2013. 
A bacia do rio Capivari, em contraste, apresenta curva de perfil convexo e integral hipsométrico igual a 0,85 . Apresentando nível de base muito mais baixo que a maior parte da bacia, o rio Capivari e seus tributários têm muito vigor para entalhar e futuramente deverão romper a face sul da cratera, promovendo sua destruição por meio de interferências de drenagem com as cabeceiras do Jurubatuba em seu interior.

O Ribeirão Vermelho também começou a romper a parede ocidental da cratera e sua cabeceira pode migrar a oeste pelo processo de decapitação, conforme a terminologia proposta por Bishop (1995).

Nota-se, deste modo, que a face leste da cratera está voltada para terrenos mais erodidos por sua bacia hidrográfica que a face oeste, conforme as diferenças nas integrais hipsométricas obtidas. A hipótese da assimetria causada por diferença no trabalho erosivo é corroborada.

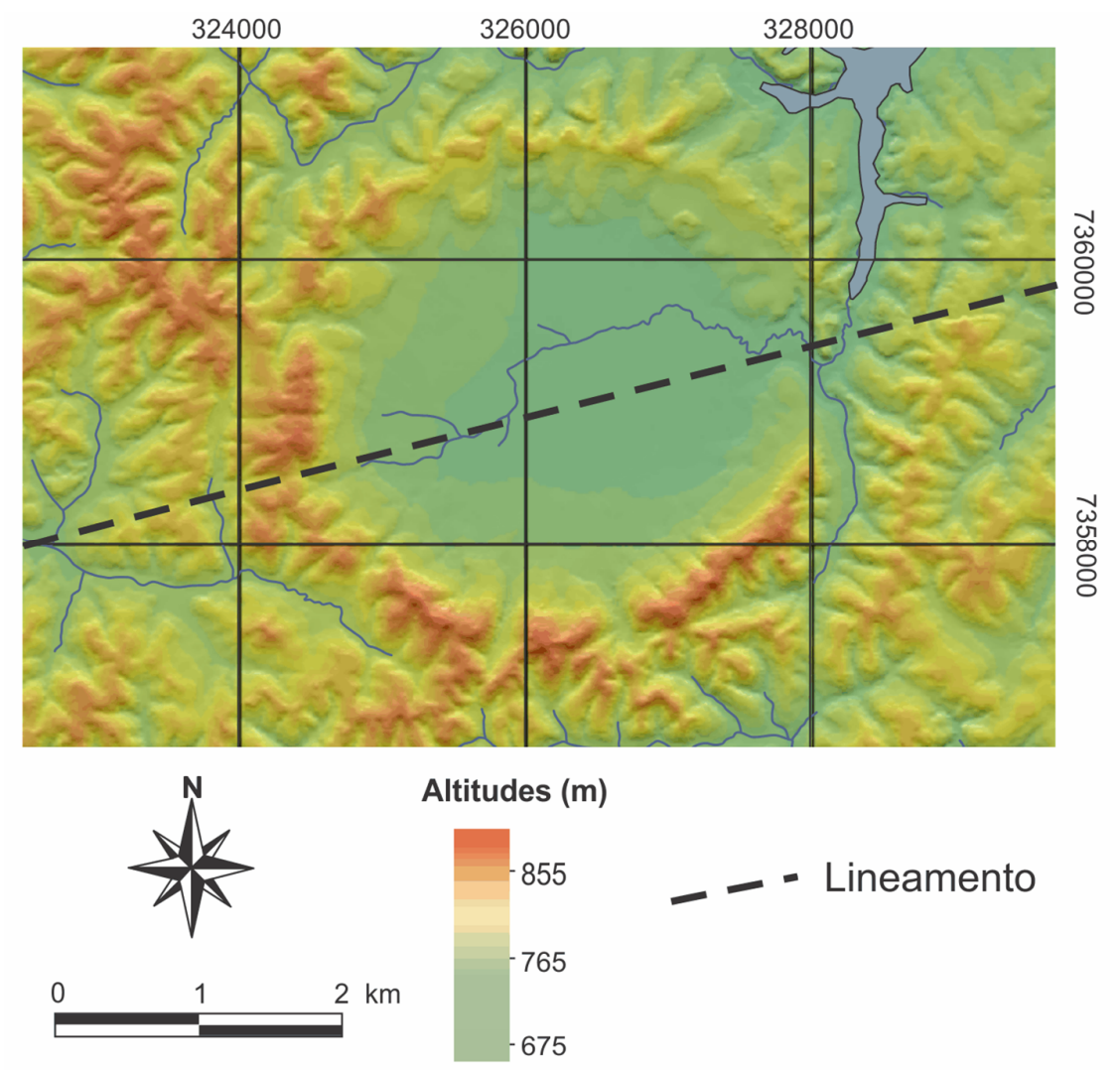

Figura 29 - Lineamento topográfico, possivelmente relacionado a uma fratura que teria condicionado o posicionamento do exutório da drenagem da cratera de Colônia. Elaborado por Santos, 2013. 
A localização exata do exutório da bacia do Ribeirão Vermelho, por sua vez, é explicável pela presença de uma fratura de direção leste-nordeste. Tal fratura teria produzido um lineamento topográfico, observável nas rupturas de declividade retilíneas e trechos retilíneos de canais no entorno da cratera (Figura 29).

Riccomini et al. (1992) afirmam que a drenagem interna da cratera era endorreica e passou recentemente a exorreica, de tal modo que um ambiente lacustre, registrado nos sedimentos quaternários, deu lugar a um ambiente fluvial, observado atualmente. Conforme estudo palinológico do pacote sedimentar realizado na cratera, elaborado por Ledru et al. (2005), a camada mais superficial de sedimentos possui aproximadamente 20.000 anos. Tal fato sugere que, a partir de então, não houve mais deposição, mas erosão, devido ao rebaixamento do nível de base associado à abertura da drenagem da cratera para o exterior.

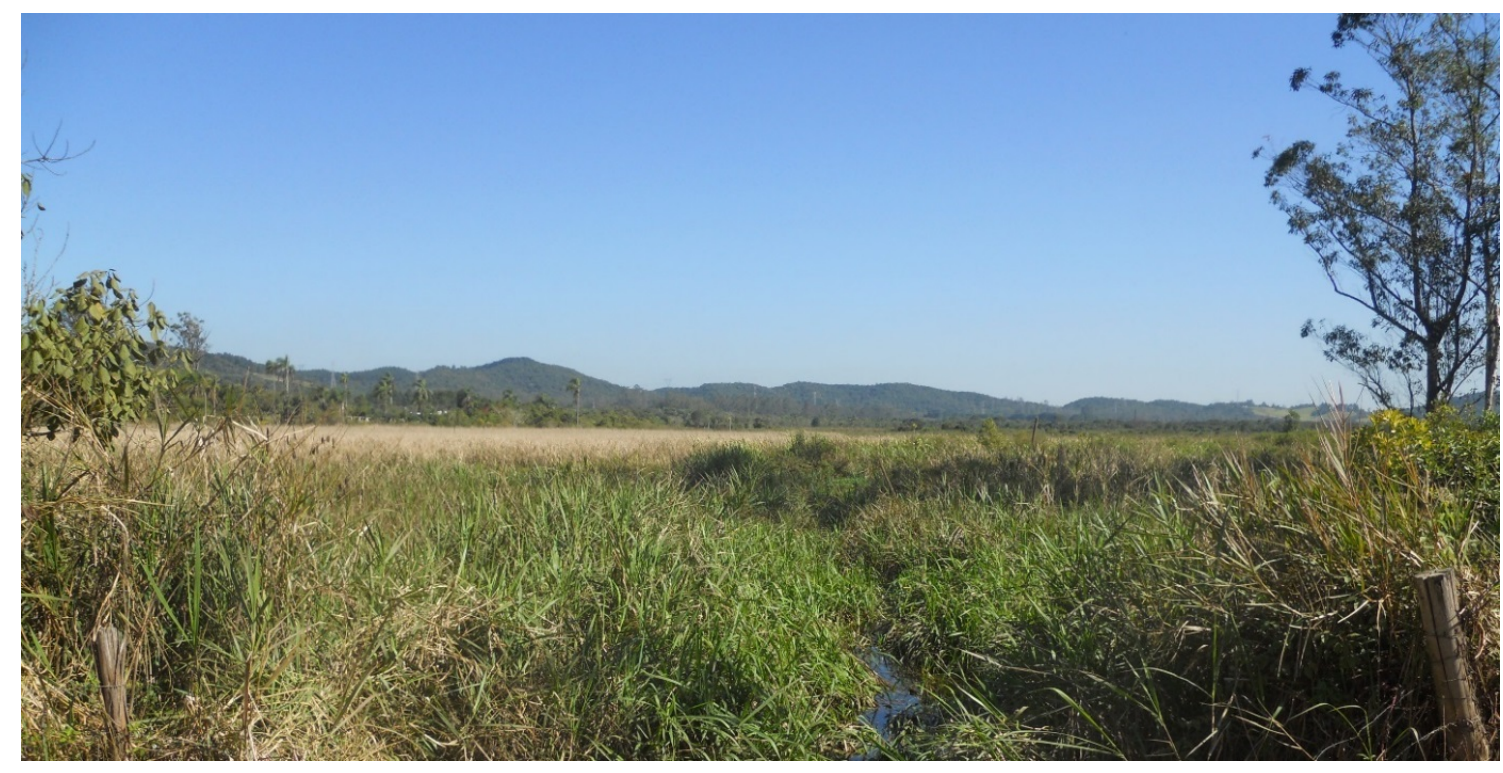

Foto 9 - Exutório da drenagem da cratera de Colônia, sem a presença de cone de dejeção. A continuidade da planície indica mudança não catastrófica da drenagem, de endorreica a exorreica. Ao fundo, anel colinoso da cratera. Obtida por Santos, 2012.

Terraços identificados na fotointerpretação (Anexo 1) atestariam essa mudança de ambiente. Eles marcam o nível mais alto da deposição e posterior entalhamento pela atividade fluvial com nível de base rebaixado pela abertura da drenagem. A altura do terraço, inferior a 5 metros indica que o evento foi recente. 
Não há dados mais precisos a respeito de como se processou a transição: se catastroficamente - com rompimento de um dique já fragilizado pela erosão fluvial a partir do exterior - ou gradualmente. Tendo a abertura da drenagem ocorrido há aproximadamente 20.000 anos, se o processo fosse catastrófico, haveriam vestígios de um cone de dejeção que marcasse o evento.

Porém, dados da fotointerpretação, do MDE e de campo (Foto 9 e Figura 30) indicam não haver um cone de dejeção no exutório da cratera, dada a continuidade da planície do Ribeirão Vermelho na saída da cratera, sem qualquer ruptura altimétrica.

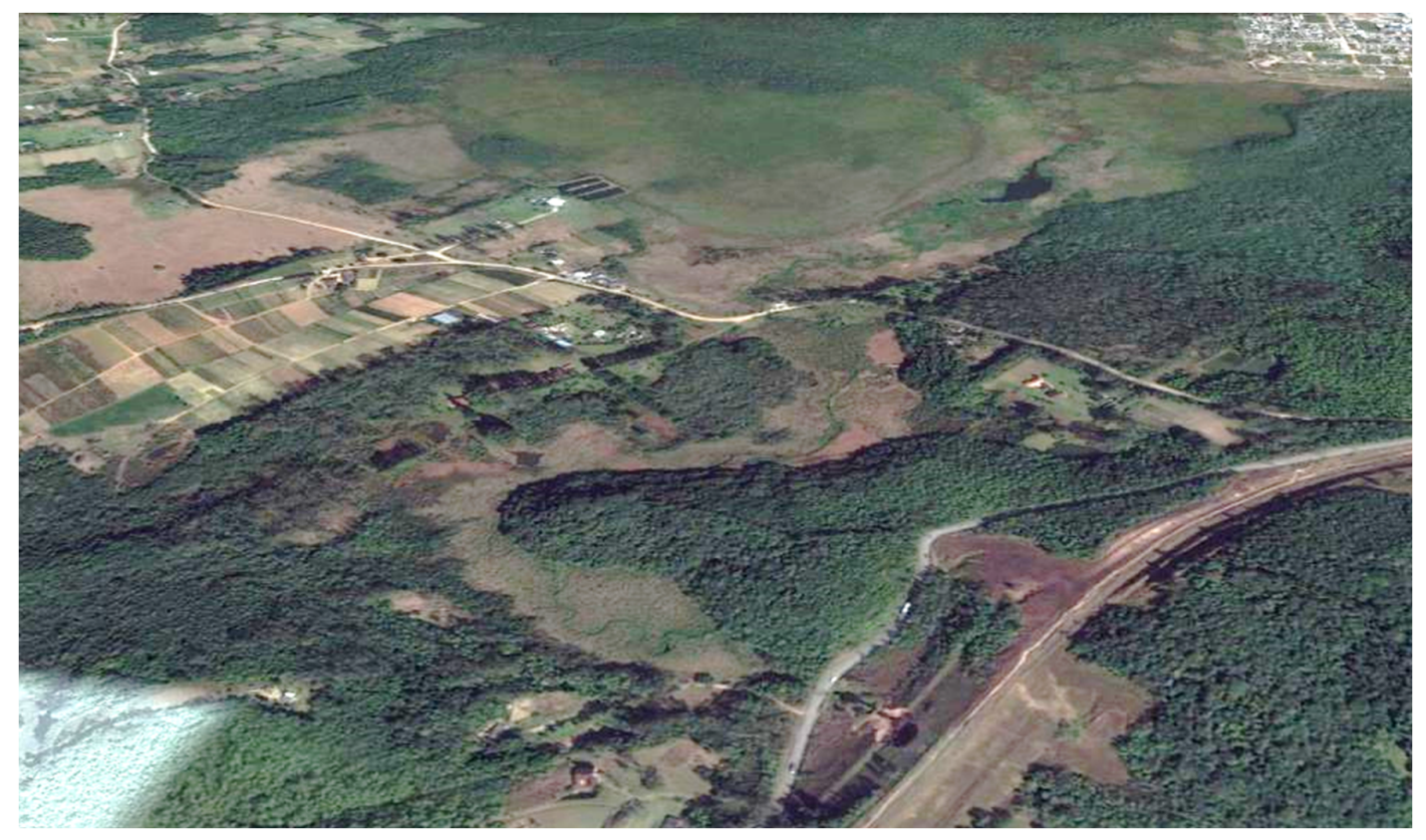

Figura 30 - Vista aérea do exutório da drenagem da cratera de Colônia, sem a presença de cone de dejeção. Visada de leste para oeste. Obtida de: Google Earth, 2013, Fonte: DigitalGlobe, 2002.

Admite-se, com base nos fatos apresentados, dissecação da cratera de Colônia vinculada à dissecação em seu entorno. O posicionamento do exutório, bem como do segmento mais rebaixado do anel colinoso a leste, correlacionam-se com o maior rebaixamento da bacia do rio Jurubatuba, a leste, que do Embu-Guaçu a oeste, sugerindo atividade erosiva diferencial como a responsável pela assimetria altimétrica da crista e pela disposição atual da rede de drenagem no interior da cratera. 


\section{CONCLUSÃO}

De acordo com os dados obtidos por meio de fotointerpretação, análise de campo e morfometria, estabelecem-se algumas considerações a respeito da origem e do desenvolvimento do relevo e da drenagem na cratera de Colônia e em seu entorno.

A primeira delas é a de que o evento que gerou a cratera de Colônia também gerou uma zona de formas concêntricas em seu entorno. A compatibilidade morfológica entre elas é muito grande para que tenham sido gerados em dois eventos independentes. Essa zona de formas concêntricas seria sustentada por uma estrutura geológica composta de feições lineares radiais e paralelas à borda da cratera, levando ao condicionamento da drenagem e do relevo, o que necessita de estudos geofísicos de detalhe para confirmação.

Quanto aos mecanismos para a formação da zona de formas concêntricas no entorno da cratera de Colônia - fraturas radiais e concêntricas formadas na ocasião do impacto, efeito da estratificação do alvo, morfologia de cratera complexa com pico anelar central, ejecta fluidificada e fluidificação de finos - considerou-se mais prudente a não admissão de qualquer uma das explicações como a mais correta, em função, principalmente, da escassez de dados geofísicos. Sobrevivem como plausíveis as hipóteses da formação do sistema de fraturas e da fluidificação de finos, possivelmente co-responsáveis pela formação e manutenção de um padrão de formas concêntricas até hoje observadas.

Uma vez formada, a estrutura teria condicionado o desenvolvimento subsequente da rede de drenagem e do relevo. O padrão anelar da drenagem, desenvolvida em uma superfície inicial deformada, teria sido preservada devido ao processo de superimposição, admissível ao se considerar a presença de remanescentes sedimentares terciários na área.

A drenagem assim desenvolvida removeu grande parte da cobertura sedimentar, restando apenas remanescentes, por vezes muito reduzidos. No entanto, a disposição espacial desses remanescentes, em forma de arcos, dá sustentação à hipótese de superimposição a partir de uma superfície deformada concentricamente.

Movimentos tectônicos posteriores à formação da estrutura de impacto geraram modificações na rede de drenagem estabelecida, visto a grande quantidade de 
knickpoints, wind gaps e inflexões abruptas a norte e, especialmente, a sul da cratera. Somam-se a essas evidências a variação espacial das integrais hipsométricas e das densidades de drenagem, ambos exibindo maiores índices nas sub-bacias que apresentam maior quantidade de anomalias de drenagem mapeadas.

A própria cratera de Colônia também foi dissecada. Sua dissecação teria sido mais intensa a leste, gerando a assimetria altimétrica observada na crista da cratera. Embora também tenha sido proposta uma origem da assimetria por obliquidade do impacto, nota-se que essa explicação não se sustenta nos exames geofísicos. As integrais hipsométricas comparadas das bacias dos rios Embu-Guaçu e Jurubatuba mostram que houve maior remoção de material rochoso desta última, de tal modo que seus tributários tiveram maior sucesso ao alcançar o interior da cratera, produzindo uma drenagem exorreica, no lugar da endorreica existente há até 20.000 anos.

Deste modo, houve uma captura do sistema de drenagem presente no interior da cratera, que se abriu para o exterior produzindo um terraço fluvial. A ausência de cones de dejeção no exutório da bacia do Ribeirão Vermelho, que atravessa a crista da cratera, evidencia que o processo de abertura foi gradual, em vez de catastrófico. 


\section{REFERÊNCIAS BIBLIOGRÁFICAS}

AB'SÁBER, A.N. Regiões de circundesnudação pós-cretácica no planalto brasileiro. Boletim Paulista de Geografia, v. 1, p. 3-21, 1949.

- Geomorfologia do Sítio Urbano de São Paulo. São Paulo, 1957,

335f. Tese de Doutorado, Faculdade de Filosofia, Ciências e Letras, Universidade de São Paulo.

. Domínio dos "mares de morros"no Brasil. Geomorfologia, v. 2, p. 1-

9, 1966.

AHNERT, F. Introduction to Geomorphology. Londres: Arnold, 1996.

ALMEIDA, F.F.M. Fundamentos geológicos do relevo paulista. Boletim do Instituto Geográfico e Geológico, v. 41, p. 167-263, 1964.

. Origem e evolução da Plataforma Brasileira. Rio de Janeiro:

DNPM-DGM, 1967.

; Carneiro, C.D.R. Origem e evolução da Serra do Mar. Revista Brasileira de Geociências, v. 28, p. 135-150, 1998.

ALVAREZ, W., CLAEYS, P., KIEFFER, S.W., Emplacement of Cretaceous-Tertiary boundary shocked quartz from Chicxulub crater, Science, v. 269, p. 930-935, 1995.

BAKER, D.M.H., HEAD, J.W., FASSET, C.I., KADIS, S.J., SMITH, D.E., ZUBER, M.T., NEUMANN, G.A. The transition from complex crater to peak-ring basin on the Moon: New observations from the Lunar Orbiter Laser Altimeter (LOLA) instrument, Icarus, v. 214, p. 377-393, 2011.

BALDWIN, R.B. The Measure of the Moon, Chicago: University of Chicago Press, 1963. 
BISHOP, P. Drainage rearrangement by river capture, beheading and diversion. Progress in Physical Geography, v. 19, p. 449-473, 1995.

BUCHER, W.H. Cryptovolcanic structures in the United States. In: 160 Congresso Internacional de Geologia, 1936, Washington. Anais do 16ํㅡㄴ Congresso Internacional de Geologia, p.1055-1034, 1936.

BUCHNER, E., SCHMIEDER, M. Mousso structure: a deeply eroded, medium-sized complex impact crater in northern Chad? Journal of African Earth Sciences, v. 49, p. 71-78, 2007.

CHAPLOT, V.; DARBOUX, F.; BOURENNANE, H.; LEGUÉDOIS, S.; SILVERA, N.; PHACHOMPHON, K. Accuracy of interpolation techniques for the derivation of digital elevation models in relation to landform types and data density. Geomorphology, v. 77, p. 126-141, 2006.

CHRISTOFOLETTI, A. Geomorfologia. São Paulo: Edgard Blücher, 1980.

COOLEY, S.W., GIS4Geomorphology: Disponível em: <http://www. gis4geomorphology.com>. Acesso em 2 abr. 2013.

COOPER Jr., H.F. A summary of explosion cratering phenomena relevant to metor impact events. In: PEPIN, D.J.; MERRIL, R.O.; RODDY, R.B. Impact and explosion cratering. Houston: Lunar Science Institute, 1977, p. 11-44.

DENCE, M.R. The nature and significance of terrestrial impact structures. 240 Congresso Internacional de Geologia, 1972, Montreal. Anais do 240 Congresso Internacional de Geologia, p. 77-89, 1972.

; Grieve, R.A.F.; Robertson, P.B. Terrestrial impact structures: principal characteristics and energy considerations. In: PEPIN, D.J.; MERRIL, R.O.; RODDY, R.B. Impact and explosion cratering. Houston: Lunar Science Institute, 1977, p. 247275. 
DIETZ, R.S. Shatter cones in cryptoexplosion structures - meteorite impact? Journal of Geology, v. 67, p. 496-510, 1959.

. Cryptoexplosion structures: a discussion. American Journal of Science, v. 261, p.650-664, 1963.

DRESSLER, B.O., REIMOLD, W.U. Terrestrial impact melt rocks and glasses. EarthScience Reviews, v. 56, p. 205-284, 2001.

FRENCH, B. M. Traces of Catastrophe: a handbook of shock-metamorphic effects in terrestrial meteorite impact structures. Houston: Lunar and Planetary Institute, 1998.

, Koeberl, C. The convincing identification of terrestrial meteorite impact structures: What works, what doesn't, and why. Earth-Science Reviews, v. 98, p. 123170, 2010.

FUDALI, R.F.; CRESSY, P.J. Investigation of a new stony meteorite from Mauritania with some additional data on its find site: Aouelloul crater. Earth and Planetary Science Letters, v. 30, p. 262-268, 1976.

GARVIN, J.B.; SCHNETZLER, C.; GRIEVE, A.F., Characteristics of large terrestrial impact structures as revealed by remote sensing studies. Tectonophysics, 216, 45-62, 1992.

GAULT, D.E.; WEDEKIND, J.A. Experimental studies of oblique impact. Proceedings of the Lunar and Planetary Science Conference. Nova York: Pergamon, 1978. 38433875.

GRIEVE, R. A. F., 1993. Impact crater: lessons from and for the Earth, Vistas in Astronomy, v. 36, p. 203-230, 1993

; Robertson, P.B. The terrestrial cratering record. Icarus, v. 38, n. 212-

229, 1979. 
; Pesonen, L.J. The terrestrial impact cratering record. Tectonophysics, v. 216, p. $1-30,1992$.

GUERRA, A.T.; GUERRA, A.J.T. Novo Dicionário Geológico-Geomorfológico. Rio de Janeiro: Bertrand Brasil, 2003.

HACK, J. T. Stream-Profile Analysis and Stream-Gradient Index. Journal Research U.S. Geology Survey. v. 1. n. 4, p. 421-429, 1973.

HARVEY, D. Explanation in Geography. Londres: Edward Arnold, 1969.

HASUI, Y.; CARNEIRO, C.D.R.; COIMBRA, A.M. The Ribeira Folded Belt. Revista Brasileira de Geociências, v. 5, p. 257-266, 1975.

HEILBRON, M.; SOARES, A.C.P.; CAMPOS-NETO, M.; SILVA, L.C.; TROW, R.; JANASI, V. Província Mantiqueira. In: MANTESSO-NETO, V.; BARTORELLI, A.; CARNEIRO, C.D.R.; BRITO-NEVES, B.B. Geologia do continente Sul-Americano: evolução da obra de Fernando Flávio Marques de Almeida. São Paulo: Beca, 2004, p. 203-234.

HENKEL, H., PESONEN, L.J., Impact craters and craterform structures in Fennoscandia, Tectonophysics, v. 216, p. 31-40, 1992

, EKNELIGODAB, T.C., AAROC, S. The extent of impact induced fracturing from gravity modeling of the Granby and Tvären simple craters, Tectonophysics, v. 485, n. 1-4, p. 290-305, 2010.

HORTON, R.E. Erosional development of streams and their drainage basins: hidrophysical approach to quantitative morphology. Bulletin of the Geological Society of America, v. 56, p. 275-370, 1945.

HOYT, W.G. Coon Mountain controversies: Meteor Crater and the development of the impact theory. Phoenix: Arizona University Press, 1987. 
JEONG, S.W. The viscosity of fine-grained sediments: A comparison of low- to medium-activity and high-activity clays. Engineering Geology, v. 154, p. 1-5, 2013.

JONES, G.H.S. Complex craters in alluvium. In: PEPIN, D.J.; MERRIL, R.O.; RODDY, R.B. Impact and explosion cratering. Houston: Lunar Science Institute, 1977, p. 163183.

JONES, W.B.; BACON, M.; HASTINGS, D.A. The Lake Bosumtwi impact crater, Ghana. Geological Society of America Bulletin, v. 92, n. I, p. 324-349, 1981.

KING, C.A.M. Techniques in Geomorphology, Londres: St. Martin's, 1971

KNOWLES, C.P., BRODE, H.L. The theory of cratering phenomena: an overview. In: PEPIN, D.J.; MERRIL, R.O.; RODDY, R.B. Impact and explosion cratering. Houston: Lunar Science Institute, 1977, p. 869-895.

KOEBERL, C. African meteorite impact craters: characteristics and geological importance. Journal of African Sciences, v. 18, p. 263-295, 1994.

KOLLERT, R.; BJÖRNBERG, A.; DAVINO, A. Estudos preliminaries de uma depressão circular na região de Colônia: Santo Amaro, São Paulo. Boletim da Sociedade Brasileira de Geologia, v. 10, n. 1, 1961.

KOMATSU, G., OLSEN, J.W., ORMÖ, J., DI ACHILLE, G., KRING, D.A., MATSUI, T. The Tsenkher structure in the Gobi-Altai, Mongolia: Geomorphological hints of an impact origin. Geomorphology, v. 74, p. 164-180, 2006.

KUMAR, P.S., KRING, D.A. Impact fracturing and structural modification of sedimentary rocks at Metor Crater, Arizona. Journal of Geophysical Research, v. 113, p.1-17, 2008.

LEDRU, M.P.; ROUSSEAU, D.D.; CRUZ JR., R.W.; RICCOMINI, C.; KARMANN, I.; MARTIN, L. Paleoclimate changes during the last 100,000 yr from a record in the Brazilian Atlantic rainforest region and interhemispheric comparison. Quaternary Research v. 64, n. 3, p. 444-450, 2005. 
Mc CALL, G.J.H. Half a century of progress in research of terrestrial impact structures: A review. Earth-Science Reviews, v. 92, p. 99-116, 2009.

MELOSH, H.J. Crater modification by gravity: A mechanical analysis of slumping. In: PEPIN, D.J.; MERRIL, R.O.; RODDY, R.B. Impact and explosion cratering. Houston: Lunar Science Institute, 1977, p. 1245-1260.

Impact cratering: a geologic process. Nova York: Oxford University

Press, 1989.

MORGAN, J.V., WARNER, M.R., COLLINS, G.S., MELOSH, H.J., CHRISTESON, G.L. Peak-ring formation in large impact craters: geophysical constraints from Chicxulub. Earth and Planetary Science Letters, v. 183, p. 347-354, 2000

MORISAWA, M. Rivers: Form and process, Londres: Longman, 1985.

MOTTA, U.S. E FLEXOR, J.M. Estudo gravimétrico da Depressão Circular de Colônia, São Paulo, Brasil. In: Congresso Internacional da Sociedade Brasileira de Geofísica, 2, Salvador. Anais, v.1, p.140-142, 1991.

NEVES, F. A. Estudo da depressão circular de Colônia-SP pelo método sísmico. Revista Brasileira de Geociências, v. 28, n. 1, p. 3-10, 1998.

NUNES, B.A.; RIBEIRO, M.I.C.; ALMEIDA, V.J.; NATALI FILHO, T. Manual Técnico de Geomorfologia. Rio de Janeiro: IBGE, 1995.

NUNES, L.H., VICENTE, A.K., CANDIDO, D.H. Clima da Região Sudeste do Brasil In: CAVALCANTI, I.F.A., FERREIRA, N.J., SILVA, M.G.A.J., DIAS, M.A.F.S. Tempo e Clima no Brasil, São Paulo: Oficina de Textos, 2009, p. 243-258.

OLIVEIRA, D. A captura do Alto Rio Guaratuba: uma proposta metodológica para o estudo da evolução do relevo na Serra do Mar, Boracéia - SP. São Paulo, 2003, 105 f. Tese de Doutorado - Faculdade de Filosofia, Letras e Ciências Humanas, Universidade de São Paulo. 
PANORAMIO - Photos of the World. Disponível em: <www.panoramio.com>. Acesso em abr. 2013.

PASSC - The Planetary and Space Science Center. Earth Impact Database. Disponível em: <http://www.unb.ca/passc/lmpactDatabase/>. Acesso em dez. 2012.

PASSOS, G.F. Inversão gravimétrica 3D em termos de uma superfície entre dois meios homogêneos: Aplicação ao astroblema de Colônia (São Paulo/SP). 1998. 39 f. Trabalho de Graduação - Instituto de Astronomia, Geofísica e Ciências Atmosféricas, Universidade de São Paulo.

PENCK, W. Morphological Analysis of Land Forms. New York: St. Martin's, 1953.

POMEROL, Charles et al. Princípios de Geologia: técnicas, modelos e teorias. São Paulo, Bookman, 2013.

PRICE, N.J., COSGROVE, J.W. Diapirs and circular features. In: Analysis of geological structures. Cambridge: Cambridge University Press, 2005

RIBEIRO, R.R. Evolução geomorfológica da Serra de Cubatão, em São Paulo. São Paulo, 2003. 122 f. Dissertação de Mestrado - Instituto de Geociências, Universidade de São Paulo.

RICCOMINI, C. Rift Continental do Sudeste do Brasil. São Paulo, 1989, 304 f. Tese de Doutorado - Instituto de Geociências, Universidade de São Paulo.

, TURCQ, B.; MARTIN, L.; MOREIRA, M.Z.; LORSCHEITTER, M.L. The Colônia Astrobleme, Brasil. Revista IG, São Paulo, v. 12, n. 1, p. 87-94, 1991.

, NEVES, F.A.P.S.; TURCQ, B. Astroblema de Colônia (São Paulo, Brasil): estágio atual de conhecimento. In: Congresso Brasileiro de Geologia, 37, 1992, São Paulo. Roteiros das Excursões. São Paulo: SBG/SP, 1992.

, SANT'ANNA, L.G.; FERRARI, A.L. Evolução geológica do Rift Continental do Sudeste Brasileiro. In: MANTESSO-NETO, V.; BARTORELLI, A.; 
BRITO-NEVES, C.D.R.; CARNEIRO, B.B. Geologia do continente Sul-Americano: evolução da obra de Fernando Flávio Marques de Almeida, São Paulo: Beca, 2004, p. 383-405.

, TURCQ, B.J., LEDRU, M.P., SANT'ANNA, L.G., FERRARI, J.A. Cratera de Colônia, SP: Provável astroblema com registros do paleoclima quaternário na Grande São Paulo. SIGEP, Disponível em: <htpp://unb.br/ig/sigep>. Acesso em 20 dez. 2012.

, CRÓSTA, A.P., PRADO, R.L., LEDRU, M.P., TURCQ, B.J., SANT'ANNA, L.G., FERRARI, J.A., REIMOLD, W.U. The Colônia structure, São Paulo, Brazil Meteoritics and Planetary Science v. 46, n. 11, p. 1630-1639, 2011.

RODDY, D.J. Large-scale impact and explosion craters: Comparisons of morphological and structural settings. In: PEPIN, D.J.; MERRIL, R.O.; RODDY, R.B. Impact and explosion cratering. Houston: Lunar Science Institute, 1977, p. 185-246.

RÖMER, W. Accordant summit Heights, summit levels and the origin of the "upper denudation level" in the Serra do Mar (SE-Brazil, São Paulo): A study of hillslope forms and processes. Geomorphology, v. 100, p. 312-327, 2008.

ROSS, J.L.S. Geomorfologia: ambiente e planejamento. São Paulo: Contexto, 1990.

- O relevo brasileiro, as superfícies de aplainamento e os níveis morfológicos. Revista do Departamento de Geografia (USP), v. 5, p. 17-31, 1991.

; Moroz, I.C. Mapa Geomorfológico do Estado de São Paulo: Escala 1:500.000. São Paulo: IPT/Fapesp, 1997.

SANTOS, A.H.B. A cratera de Colônia no contexto do Planalto Paulistano: Estudo das relações entre a gênese e o modelado da estrutura de impacto e o desenvolvimento do relevo e da drenagem no reverso da Serra do Mar em São Paulo-SP. 2009. 181 f. Trabalho de Graduação - Faculdade de Filosofia, Letras e Ciências Humanas, Universidade de São Paulo. 
SANTOS, A.H.B. Análise de magnitude-frequência de eventos pluviométricos na região de Parelheiros (São Paulo-SP), Revista Geonorte, v. 1, n. 4, p.399-411, 2012.

SAVIGEAR. R.A.G. A technique of morphological mapping. Annals of the Association of American Geographers, v. 55, n. 3, p. 514-538, 1965.

SCHON, S.C., HEAD, J.W., BAKER, D.M.H., ERNST, C.M., PROCKTER, L.M., MURCHIE, S.L., SOLOMON, S.C. Eminescu impact structure: Insight into the transition from complex crater to peak-ring basin on Mercury. Planetary and Space Science, v. 59, p. 1949-1959, 2011

SCHULTZ, P.H.; LIANZA, R.E. Recent grazing impacts on the Earth recorded in the Rio Cuarto crater field, Argentina. Nature, v. 355, p.234-237, 1992.

ANDERSON, R.R. Asymmetry of the Manson impact structure: Evidence for impact angle and direction. Geological Society of America: Special Paper, v. 302, p. 397-417, 1996.

SHOEMAKER, E.M. Why study impact craters? In: PEPIN, D.J.; MERRIL, R.O.; RODDY, R.B. Impact and explosion cratering. Houston: Lunar Science Institute, 1977, p. 1-10.

SMALL, R. J. The Study of Landforms: a Textbook of Geomorphology. Cambridge: Cambridge, University Press, 1970.

SOUZA, D.V., Martins, A.A., Faria, A.L.L. Aplicação do Índica de Hack (SL) a um trecho do rio Zêzere, Portugal. Revista Brasileira de Geomorfologia, v. 12, n. 1, 2011.

STRAHLER, A.N. Dynamic basis of Geomorphology. Geological Society of America Bulletin, v. 63, p. 923-938, 1952.

TARIFA, J.R.; ARMANI, G. Unidades climáticas naturais. In: TARIFA, J.R.; AZEVEDO, T.R. (orgs.) Os climas na cidade de São Paulo. São Paulo: FFLCH-USP, 2001. 
TREFIL, J.S.; RAUP, D.M. Crater taphonomy and bombardment rates in the Phanerozoic. Journal of Geology, v. 98, p. 385-398, 1990.

TRICART, J. Principes et methodes de la géomorphologie. Paris: Masson, 1965.

TWIDALE, C.R. River patterns and their meaning. Earth-Science Reviews, v. 67, p. 159-218, 2004

VARGAS, M. Os solos da cidade de São Paulo (histórico das pesquisas). São Paulo: ABGE, 2002.

VELAZQUEZ, V.F., RICCOMINI, C., SOBRINHO, J.M.A., PLETSCH, M.A.J.S., SALLUN, A.E.M., SALLUN FILHO, W., HACHIRO, J. Evidence of schock metamorphism effects in allochtonous breccia deposits from de Colônia Crater, São Paulo, Brazil. International Journal of Geosciences, v. 4, p. 274-282, 2013. 